HELIUM AND LEAD ISOTOPE GEOCHEMISTRY OF OCEANIC VOLCANIC ROCKS FROM THE EAST PACIFIC AND SOUTH ATLANTIC

by

DAVID W. GRAHAM

B.S., Florida Insitute of Technology, 1975

M. S., University of Rhode Island, 1980

SUBMITTED IN PARTIAL FULFILLMENT

OF THE REQUIREMENTS FOR THE DEGREE OF

DOCTOR OF PHILOSOPHY

at the

MASSACHUSETTS INSTITUTE OF TECHNOLOGY

and the

WOODS HOLE OCEANOGRAPHIC INSTITUTION

September, 1987

๑David W. Graham

The author hereby grants to MIT and WHOI permission to reproduce and distribute copies of this thesis document in whole or in part.

Signature of Author

Joint program in Oceanography, Massachusetts Institute of

Technology and Woods Hole Oceanographic Institution, and the

Department of Earth, Atmospheric, and Planetary Sciences, Massachusetts Institute of Technology

Certified by

Will iam J. Jehkins, Thesis Supervisor

Accepted by

John Edmond, Chatir, Joint Committee for Chemical Oceanography,

Massachusetts Institute of Technology/Woods Hole Oceanographic

Institution 


\title{
HELIUM AND LEAD ISOTOPE GEOCHEMISTRY OF OCEANIC VOLCANIC ROCKS FROM THE EAST PACIFIC AND SOUTH ATLANTIC
}

by

\author{
DAVID W. GRAHAM
}

\section{ABSTRACT}

The isotopic evolution of helium and lead in the Earth is coupled by virtue of their common radioactive parents uranium and thorium. The isotopic signatures in oceanic volcanic rocks provide constraints on the temporal evolution of mantle source regions and volcanic magmas. He and $\mathrm{Pb}$ isotopes were measured in glassy basalts from young seamounts in the East Pacific, and in phenocrysts and corresponding whole rocks, respectively, from the island of St. Helena. He isotopes were also measured in glassy mid-ocean ridge basalts from the South Atlantic, previously studied for $\mathrm{Pb}$ isotopes by Hanan et al. (1986).

A precise reconstruction of $\mathrm{He}-\mathrm{Pb}$ isotope relationships in volcanic source regions is complicated by post-eruptive radiogenic ingrowth of ${ }^{4} \mathrm{He}$ in non-zero age basalts, by pre-eruptive radiogenic ingrowth of ${ }^{4} \mathrm{He}$ in magmas with elevated $(U+T h) / H e$, by multi-stage fractionation processes involving $(U+T h) / H e, U / P b$ and $T h / P b$ and by convective mixing in the Earth's interior. Aspects of each of these problems are addressed.

$(U+T h) / H e$ ages are estimated from the isotope disequilibrium of ${ }^{3} \mathrm{He} /{ }^{4} \mathrm{He}$ between He trapped in vesicles and that dissolved in the glass phase of young alkali basalts at seamount 6 in the East Pacific. ${ }^{3} \mathrm{He} /{ }^{4} \mathrm{He}$ in the glass phase of these alkali basalts is subatmospheric, while in the vesicles it ranges between 1.2-2.5 $R_{A}\left(R_{A}=\right.$ atmospheric ratio). ${ }^{3} \mathrm{He} /{ }^{4} \mathrm{He}$ in vesicles (extracted by crushing in vacuo) allows a correction to be made in the dissolved phase He (by fusion of the remaining powder) for the inherited component in order to compute the radiogenic [He]. The method is applicable to rocks containing phases with different $(U+T h) / H e$, and the results have implications for dating Tavas in the age range of $10^{3}$ to $10^{6}$ years, and for reconstructing the temporal evolution of young volcanic systems.

$\mathrm{Pb}, \mathrm{Sr}$ and $\mathrm{Nd}$ isotopic variability observed at a small seamount field between $9-14^{\circ} \mathrm{N}$ near the East Pacific Rise covers $\sim 80 \%$ of the variability for Pacific MORB, due to smal1-scale heterogeneity in the underlying mantle. Tholeiftes at these seamounts have $\mathrm{He}, \mathrm{Pb}, \mathrm{Sr}$ and $\mathrm{Nd}$ isotope compositions which are indistinguishable from MORB. Associated alkali basalts show more radiogenic $\mathrm{He}, \mathrm{Pb}$ and $\mathrm{Sr}$ signatures. The lower 
${ }^{3} \mathrm{He} /{ }^{4} \mathrm{He}$ of $\mathrm{He}$ trapped in vesicles of these alkali basalts (1.2-2.6 $R_{A}$ ) is associated with low helium concentrations $\left(<5 \times 10^{-8} \mathrm{ccSTP} / \mathrm{g}\right)$. Evolved alkalj basalts have lower ${ }^{3} \mathrm{He} /{ }^{4} \mathrm{He}\left(1.2-1.8 \mathrm{R}_{\mathrm{A}}\right)$ than primitive alkali basalts $\left(2.4-2.6 R_{A}\right)$, suggesting some degree of magmatic control on inherited ${ }^{3} \mathrm{He} /{ }^{4} \mathrm{He}$ in these alkalic lavas. Collectively, the isotopic results suggest that as the lithosphere ages, material transfer from the MORB source becomes less significant because smaller degrees of melting average the chemical characteristics of heterogeneous mantle volumes less efficiently than near the ridge.

Icelandites erupted at Shimada Seamount, an isolated volcano on 20 m.y. old seafloor, have $\mathrm{Pb}, \mathrm{Sr}$ and $\mathrm{Nd}$ isotopic compositions similar to post-erosional basalts at Samoa. ${ }^{3} \mathrm{He} /{ }^{4} \mathrm{He}$ at Shimada ranges between 3.9-4.8 $R_{A}$ and helium concentrations are too large for radiogenic contamination of magma to have lowered the ${ }^{3} \mathrm{He} /{ }^{4} \mathrm{He}$ appreciably. These results indicate the presence of an enriched mantle component previously unidentified beneath the East Pacific. Its low ${ }^{3} \mathrm{He} /{ }^{4} \mathrm{He}$ may be due to the melting of domains with high $\left(U_{+} T h\right) / H e$ which formed during accretion of the oceanic lithosphere. Alternatively, it is an inherent characteristic of the source, which contains material recycled into the mantle at subduction zones.

The mid-ocean ridge between $12-46^{\circ} \mathrm{S}$ in the South Atlantic displays ${ }^{3} \mathrm{He} /{ }^{4} \mathrm{He}$ lower than typical MORB values. Local anomalies occur at the latitudes of off-axis islands to the east, apparently due to contamination of depleted mantle asthenosphere by hotspot materials (as previously shown for $(\mathrm{La} / \mathrm{Sm})_{\mathrm{N}}$ and $\mathrm{Pb}$ isotopes; Schilling et al., 1985; Hanan et al., 1986). He - $\mathrm{Pb}$ isotopic relationships along the $12-22^{\circ} \mathrm{S}$ ridge segment suggest that $\mathrm{St}$. Helena has ${ }^{3} \mathrm{He} /{ }^{4} \mathrm{He}$ less than MORB. ${ }^{3} \mathrm{He} /{ }^{4} \mathrm{He}$ in two St. Helena rocks (extracted by in vacuo crushing of olivine and pyroxene) is $5.8 \mathrm{R}_{\mathrm{A}}$ when the extracted ${ }^{3} \mathrm{He}$ contents are greater than $1 \times 10^{-13} \mathrm{CCSTP} / \mathrm{g}$, consistent with the He - $\mathrm{Pb}$ observations along the St. Helena ridge segment.

${ }^{4} \mathrm{He} /{ }^{3} \mathrm{He}$ and radiogenic $\mathrm{Pb}$ isotope ratios are linearly correlated for the South Atlantic ridge segment between $2-12^{\circ} \mathrm{S}$. Linear correlation of ${ }^{4} \mathrm{He} /{ }^{3} \mathrm{He}-{ }^{206} \mathrm{~Pb} /{ }^{20}{ }^{4} \mathrm{~Pb}$ within an oceanic rock suite reflects the temporal evolution of ${ }^{204} \mathrm{~Pb} /{ }^{3} \mathrm{He}$ in the source. A linear correlation between volcanic suites derived from i sotopically different sources (e.g., oceanic islands) may imply a coherent fractionation of $\left(U_{+} T h\right)$ from He and $\mathrm{Pb}$ during the evolutionary history of their respective mantle source regions.

Thesis Supervisor: Dr. William J. Jenkins

Senior Scientist, Dept. of Chemistry, W.H.O.I. 


\section{ACKNOWLEDGMENTS}

This work could not have been accomplished without the contributions of many individuals. Bill Jenkins has supported me since the beginning of my graduate work at WHOI, by encouraging me to continually improve my understanding of geochemistry and analytical techniques. The completion of this work is a tribute to his patient guidance, and to the nearly total freedom with which he allowed me to work in the helium isotope lab.

Mark Kurz taught me much of what I know about measuring helium isotopes in rocks and influenced my thinking about the relation between helium and other isotopic systems. Dempsey Lott performed cryogenics and vacuum line wizardy on numerous occasions. Together Mark and Dempsey designed and constructed the high temperature furnace and helium extraction line which made low level helium isotope measurements possible. Other lab personnel were instrumental in dealing with numerous crises, both scientific and personal, including Tom Trull, Marcia Davis, Peggy Dickinson, Bill Spitzer, John Bullister, Scott Birdwhistell, Dan Sampson, Danuta Kaminski, and Mireille Polvé.

Alan Zindler invited me to do the lead, strontium and neodymium isotope chemistry at Lamont-Doherty Geological Observatory. He provided a dynamic environment highlighted by all-night mass spec runs. I made numerous friends there and enjoyed their outlook on geologic, as well as other problems. Jim Rubenstone was especially helpful. Other notable Lamontsters include Laurie Reisberg, Gerd Worner, Kye-Hun Park, Bruno Hamelin and Hubert Staudigel.

Rodey Batiza initially pointed out the importance of seamounts as windows to volcanoes and the mantle. His generosity with samples and insight to geologic processes was an inspiration. Jamie Allan, Terri Smith and Pat Castillo, the petrology crew at Washington University, provided a friendly atmosphere for two sampling expeditions to St. Louis. Stan Hart helped me focus ideas of magma evolution and isotope relationships into more quantitative scenarios. Geoff Thompson offered helpful ideas on South Atlantic geochemistry.

Many thanks to the friends who helped out in times of need, openiy listened to half-baked ideas, and offered constructive advice; Peter Meyer, Tom Trull, Tanya Furman, Kevin Johnson, Bill Martin, Ann McNichol, Henry Dick, Lloyd Keigwin, Susan Humphri.s, and Margaret Sulanowska.

Thanks to the persons who donated samples; Rodey Batiza (Pacific seamounts), Geoff Thompson and Jean-Guy Schilling (South Atlantic MORB), Jim Gardner (Shimada seamount), Susan Humphris (St. Helena), Jim Natland (East Pacific Rise alkali basalts), Mireille Polvé (Tubuaij) and Joe Devine and Haraldur Sigurdsson (Kick'em Jenny). Beecher Wooding made high quality thin sections. 
Susan Kadar, and the Education office at WHOI kept me out of trouble for 5 years (most of the time). The work was supported by grants from the National Science Foundation, including OCE 15270 and 16082 (He isotopes) and OCE 10615 and EAR 51182 (Pb, Sr and $\mathrm{Nd}$ isotopes).

Thanks to Michael Bender, who first inspired me to study geochemistry. Most of al1, I thank the friends who provided the moral support that I could not have done without; Paul and Lisa Newton, Peter Meyer and Tanya Furman. This study is dedicated to my Mom. 


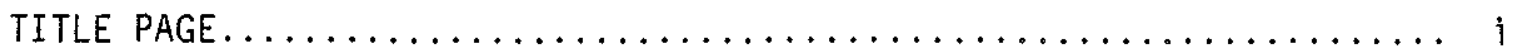

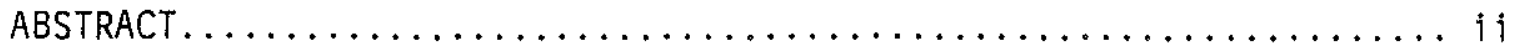

ACKNOWLEDGMENTS $\ldots \ldots \ldots \ldots \ldots \ldots \ldots \ldots \ldots \ldots \ldots \ldots \ldots \ldots \ldots \ldots \ldots \ldots$

TABLE OF CONTENTS $\ldots \ldots \ldots \ldots \ldots \ldots \ldots \ldots \ldots \ldots \ldots \ldots \ldots \ldots \ldots \ldots$

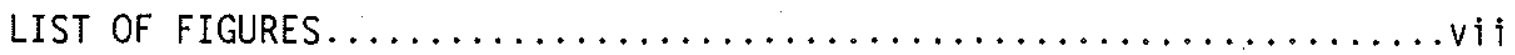

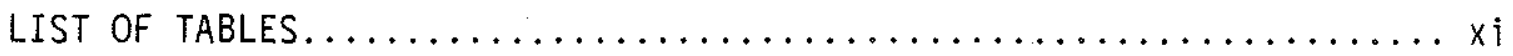

CHAPTER $1-$ INTRODUCTION.........................

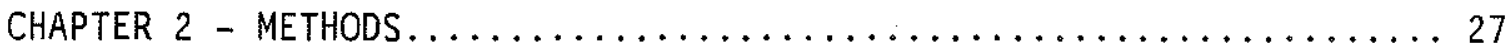

CHAPTER 3 - HELIUM ISOTOPE DISEQUILIBRIUM IN GLASSY

SUBMARINE BASALTS $\ldots \ldots \ldots \ldots \ldots \ldots \ldots \ldots \ldots \ldots \ldots \ldots \ldots$

CHAPTER 4 - HELIUM, LEAD, STRONTIUM AND NEODYMIUM ISOTOPE

CONSTRAINTS ON MAGMA GENESIS AND MANTLE HETEROGENEITY

BENEATH YOUNG PACIFIC SEAMOUNTS,............. 71

CHAPTER 5 - HELIUM AND LEAD ISOTOPE SYSTEMATICS IN SOUTH ATLANTIC

MORB AND VOLCANIC ROCKS FROM THE ISLAND OF ST. HELENA...162

CHAPTER 6 - TERRESTRIAL HELIUM-LEAD ISOTOPE EVOLUTION..........213

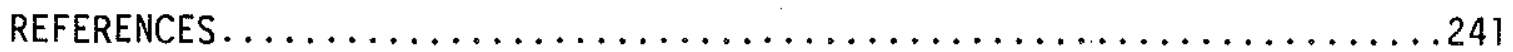

APPENDIX 1 - ST. HELENA SAMPLE DESCRIPTIONS ................... 251 


\section{LIST OF FIGURES}

page

Chapter 1

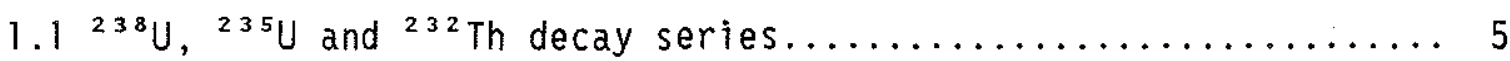

1.2 Fractional lowering of ${ }^{3} \mathrm{He} /{ }^{4} \mathrm{He}$ by radiogenic ingrowth........ 9

1.3 Fractional lowering of "planetary" ${ }^{3} \mathrm{He} /{ }^{4} \mathrm{He} \ldots \ldots \ldots \ldots \ldots \ldots \ldots$

$1.4^{207} \mathrm{~Pb} /{ }^{204} \mathrm{~Pb}-{ }^{206} \mathrm{~Pb} /{ }^{204} \mathrm{~Pb}$ evolution in the Earth.......... 14

$1.5^{208} \mathrm{~Pb} /{ }^{204} \mathrm{~Pb}-{ }^{206} \mathrm{~Pb} /{ }^{204} \mathrm{~Pb}$ evolution in the Earth........... 16

1.6 Cartoon of seamount evolution (from Batiza, 1977).......... 23

\section{Chapter 2}

$2.1 \mathrm{~Pb}$ isotope results for NBS SRM $981 \ldots \ldots \ldots \ldots \ldots \ldots \ldots \ldots \ldots \ldots$

2.1 Schematic diagram of the He isotope processing line......... 35

\section{Chapter 3}

3.1 Histogram of He isotope disequilibrium at seamount $6 \ldots \ldots \ldots \ldots$

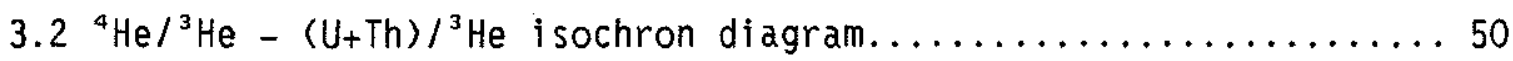

$3.3(U+T h) /{ }^{3} \mathrm{He}$ isochrons for seamount 6 alkali basalts......... 52

3.4 Vesicle-glass partitioning of ${ }^{3} \mathrm{He}$ at seamount $6 \ldots \ldots \ldots \ldots \ldots$

3.5 Model for partial vesicle-glass equilibration............. 62

3.6 SEABEAM map of ages for seamount 6 basalts.............. 65

$3.7 \mathrm{Mg} \#$ vs. Age for seamount 6 alkali basalts $\ldots \ldots \ldots \ldots \ldots \ldots \ldots 6$

3.8 Inherited He vs. Age for seamount 6 alkali basalts..........69 


\section{Chapter 4}

4.1 Map of East Pacific seamounts.................... 75

$4.2\left(\mathrm{Na}_{2} \mathrm{O}+\mathrm{K}_{2} \mathrm{O}\right)$ vs. $\mathrm{SiO}_{2}$ for seamount samples................ 77

$4.3^{207} \mathrm{~Pb} / 204 \mathrm{~Pb}$ and ${ }^{208} \mathrm{~Pb} /{ }^{204} \mathrm{~Pb}$ VS, ${ }^{206} \mathrm{~Pb} /{ }^{204} \mathrm{~Pb}$

for seamounts and some Pacific islands................. 83

$4.4^{143} \mathrm{Nd} / /^{144} \mathrm{Nd}$ vs. ${ }^{87} \mathrm{Sr} /{ }^{86} \mathrm{Sr}$ for Pacific seamounts and islands.... 85

$4.5^{87} \mathrm{Sr} /{ }^{86} \mathrm{Sr}$ vs. ${ }^{206} \mathrm{~Pb} /{ }^{204} \mathrm{~Pb}$ for Pacific seamounts and islands.....87

$4.6{ }^{143} \mathrm{Nd} / /^{144} \mathrm{Nd}$ vs. ${ }^{206} \mathrm{~Pb} /{ }^{204} \mathrm{~Pb}$ for Pacific seamounts and islands... 89

$4.7{ }^{3} \mathrm{He} /{ }^{4} \mathrm{He},{ }^{206} \mathrm{~Pb} /{ }^{204} \mathrm{~Pb},{ }^{87} \mathrm{Sr} /{ }^{86} \mathrm{Sr}$ and

${ }^{143} \mathrm{Nd} / /^{144} \mathrm{Nd}$ vs. seafloor age for EPR seamounts............ 91

$4.8^{143} \mathrm{Nd} / /^{144} \mathrm{Nd} v s .{ }^{87} \mathrm{Sr} /{ }^{86} \mathrm{Sr}$ for EPR seamounts.............. 94

4.9 Histogram of ${ }^{3} \mathrm{He} /{ }^{4} \mathrm{He}$ at Pacific seamounts..............

$4.10{ }^{3} \mathrm{He} /{ }^{4} \mathrm{He}$ and $[\mathrm{He}]$ vs. Mg\# for Pacific seamounts............. 103

$4.11^{143} \mathrm{Nd} / /^{144} \mathrm{Nd}$ vs. $1 /[\mathrm{Nd}]$ and ${ }^{87} \mathrm{Sr} /{ }^{86} \mathrm{Sr}$ vs.

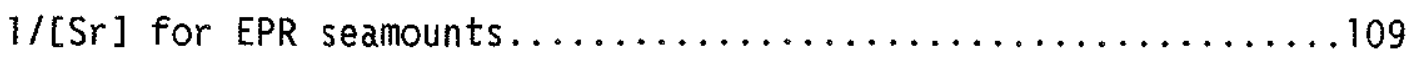

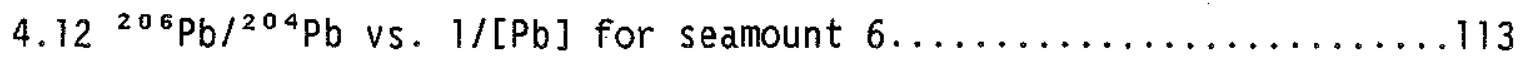

$4.13 \mathrm{Sm-Nd}$ "isochron" diagram for small EPR seamounts........... 115

$4.14 \mathrm{U}-\mathrm{Pb}$ "isochron" diagram for seamount 6 samples and some

Pacific MORB glasses......................... 117

$4.15(\mathrm{La} / \mathrm{Sm})_{\mathrm{N}}$ vs. ${ }^{206} \mathrm{~Pb} /{ }^{204} \mathrm{~Pb}$ for Pacific seamounts............ 120

$4.16{ }^{3} \mathrm{He} /{ }^{4} \mathrm{He}$ vs. volcano volume for East Pacific seamounts.........127

$4.17{ }^{3} \mathrm{He} /{ }^{4} \mathrm{He}$ vs. [He] for Pacific seamounts................... 131

$4.18 \mathrm{Mg \#}$ vs. "magma residence time" for seamount 6 alkali basalts...136 
4.19 Continuous diffusive loss model of Hart and Zindler (1987) for helium in a $1 \mathrm{~km}$ diameter magma chamber........... 140

4.20 Continuous diffusive loss model for helium in a $0.2 \mathrm{~km}$

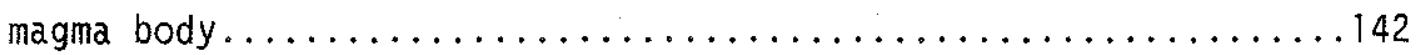

$4.21{ }^{3} \mathrm{He} /{ }^{4} \mathrm{He}$ vs. time for $1 \mathrm{~km}$ and $0.2 \mathrm{~km}$ magma bodies.........

4.22 Magma sphere cooling model....................... 147

$4.23{ }^{3} \mathrm{He} /{ }^{4} \mathrm{He}$ vs. ${ }^{87} \mathrm{Sr} /{ }^{86} \mathrm{Sr}$ for seamount glasses, some

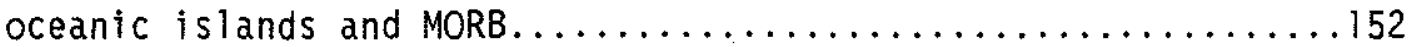

$4.24{ }^{3} \mathrm{He} /{ }^{4} \mathrm{He}$ vs. ${ }^{206} \mathrm{~Pb} /{ }^{204} \mathrm{~Pb}$ for Pacific seamounts............

4.25 Cartoon for separation of $(U+T h)$ from He in the mantle during melting beneath a mid-ocean ridge $\ldots \ldots \ldots \ldots \ldots \ldots \ldots 8$

\section{Chapter 5}

5.1 Locations of South Atlantic MORB samples................. 167

$5.2 \mathrm{~Pb}$ isotope variations in the South Atlantic along the

ridge axis (from Hanan et al., 1986)....................69

5.3 Map of sample locations on St. Helena................... 174

$5.4{ }^{4} \mathrm{He} /{ }^{3} \mathrm{He},(\mathrm{La} / \mathrm{Sm})_{\mathrm{N}}$ and bathymetry vs. latitude

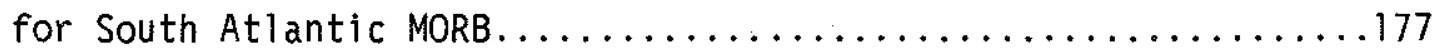

$5.5 \mathrm{Histogram}$ of ${ }^{3} \mathrm{He} /{ }^{4} \mathrm{He}$ in South Atlantic MORB..............

$5.6{ }^{3} \mathrm{He} /{ }^{4} \mathrm{He}$ vs. $(\mathrm{La} / \mathrm{Sm})_{N}$ for South Atlantic MORB............

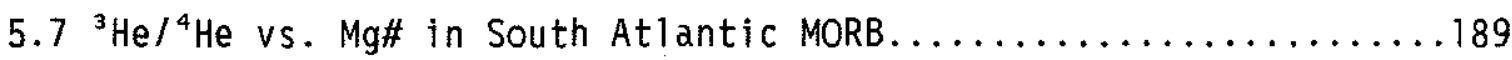

$5.8{ }^{4} \mathrm{He} /{ }^{3} \mathrm{He}$ vs. ${ }^{206} \mathrm{~Pb} /{ }^{204} \mathrm{~Pb}$ for South Atlantic MORB............. 191 
$5.9^{4} \mathrm{He} /{ }^{3} \mathrm{He}$ vs. ${ }^{207} \mathrm{~Pb} /{ }^{204} \mathrm{~Pb}$ for South Atlantic MORB............

$5.10^{4} \mathrm{He} /{ }^{3} \mathrm{He}$ vs. ${ }^{208} \mathrm{~Pb} /{ }^{204} \mathrm{~Pb}$ for South Atlantic MORB..........

5.11 Total fusion ${ }^{4} \mathrm{He} /{ }^{3} \mathrm{He}$ vs. $\left.1 /{ }^{3} \mathrm{He}\right]$ for South Atlantic MORB......200

$5.12^{208} \mathrm{~Pb} /{ }^{204} \mathrm{~Pb}$ and ${ }^{207} \mathrm{~Pb} /{ }^{204} \mathrm{~Pb}$ Vs. ${ }^{206} \mathrm{~Pb} /{ }^{204} \mathrm{~Pb}$

for St. Helena volcanic rocks......................... 205

$5.13{ }^{4} \mathrm{He} /{ }^{3} \mathrm{He}$ vs. $1 /\left[{ }^{3} \mathrm{He}\right]$ for St. Helena phenocrysts............208

\section{Chapter 6}

$6.1^{4} \mathrm{He} /{ }^{3} \mathrm{He}-{ }^{206} \mathrm{~Pb} /{ }^{204} \mathrm{~Pb}$ planetary evolution diagram............

6.2 Two-stage fractionation model for the ${ }^{4} \mathrm{He} /{ }^{3} \mathrm{He}-$

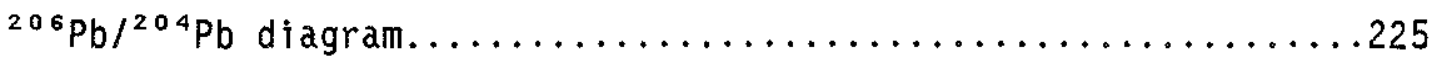

$6.3^{4} \mathrm{He} /{ }^{3} \mathrm{He}$ vs. ${ }^{206} \mathrm{~Pb} /{ }^{204} \mathrm{~Pb}$ for oceanic rocks........................

6.4 Residence time for upper mantle $\mathrm{He} \ldots \ldots \ldots \ldots \ldots \ldots \ldots \ldots \ldots \ldots \ldots$ 


\section{LIST OF TABLES}

page

\section{Chapter 1}

1.1 Heat and Helium Production by Radioactive Nuclides.......... 19

\section{Chapter 2}

2.1 He Isotope Analyses of ALV $5192-1-A \ldots \ldots \ldots \ldots \ldots \ldots \ldots \ldots$

\section{Chapter 3}

$3.1(U+T h) /$ He Ages for Seamount 6 Basalts.................. 44

3.2 Stepwise Crushing Results for Seamount 6 Basalts...........57

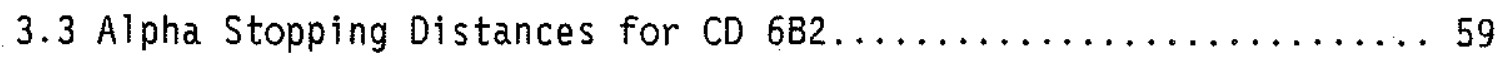

\section{Chapter 4}

4.1 East Pacific Seamounts Studied..................... 73

4.2 Representative Analyses of Seamount Basalts.............. 74

4.3 Lead, Strontium and Neodymium Isotope Compositions

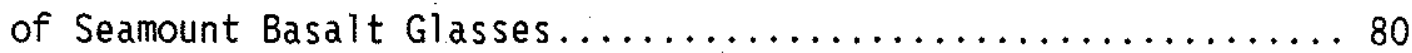

4.4 Helium Isotope Compositions of Seamount Basalt Glasses....... 96

4.5 Lead Isotope Evolutionary Parameters for

East Pacific Seamount Basalts........................... 121 


\section{Chapter 5}

5.1 Sample Locations and Lead Isotope Compositions of South Atlantic MORB (from Hanan et al., 1986).............. 170

5.2 Helium Isotope Compositions for South Atlantic MORB.......... 180

5.3 Comparison of ${ }^{3} \mathrm{He} /{ }^{4} \mathrm{He}$ for South Atlantic Ridge Segments....... 185

5.4 Helium and Lead Isotope Compositons for Rocks

from St. Helena, Tubuai $i$ and Kick'em Jenny...............203

\section{Chapter 6}

6.1 Episodic Helium-Lead Evolutionary Parameters...............223

6.2 Hel ium-Lead-Strontium and Neodymium I sotope

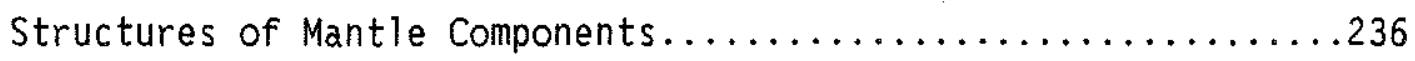




\section{CHAPTER 1}

INTRODUCTION 
Understanding the origin and generation of partially molten rock and its ultimate eruption from volcanoes is of fundamental importance in geochemistry. In this study I attempt to constrain some aspects of the time scales associated with processes in mantle source regions and volcanic complexes. To this aim, the isotope geochemistry of helium and lead has been studied in oceanic volcanic rocks from the East Pacific and South Atlantic.

\subsection{The Isotope Diversity of Oceanic Rocks}

The isotope diversity of oceanic rocks is compelling evidence that the earth's mantle is chemically and isotopically heterogeneous. The sources for mid-ocean ridge (MORB) and ocean island basalts (OIB) are geochemically distinct, but the origin, scale and geometric relation of the source reservoirs remain points of debate. For example, alkali basalts, which erupt primarily away from spreading ridges, are of ten derived from less depleted mantle than tholeites erupted at mid-ocean ridges. Alkalic magmas may result from either small degrees of melting of peridotite or eclogite (Kushiro, 1973; Jacques and Green, 1980) or larger degrees of melting at higher pressure (Green, 1973; Green and Ringwood, 1967). Their different isotope compositions may thus be explained if the scale of source regions sampled by melting is comparable to the scale of isotope heterogeneity (Zindler et al., 1984). Alternatively, alkali basalts may be derived by melting of deeper, isotopically different material (Allègre et al., 1980). The depleted mantle (as sampled by MORB) is probably not a closed system, but has been periodically contaminated with less depleted material. The nature and 
origin of these contaminants and their mode of entry into the mantle remain conjectural. These may include recycled crustal or lithospheric material (Hofmann and White, 1982; Ringwood, 1982; Kurz et a1., 1982a; McKenzie and O'Nions, 1984), blobs of "primitive" lower mantle (Allègre et a1., 1984; Allègre and Turcotte, 1985), and metasomatic components that arise from either the upper/lower mantle (or core/mantle) boundary (Allègre and Turcotte, 1985; Zindler and Hart, 1986a), the asthenosphere/lithosphere boundary (Anderson, 1985; Duncan et al., 1986; Stille et al., 1986) or within the mantle itself (Sun and Hanson, 1975; Al Tegre et a1., 1980).

The isotope variations of $\mathrm{Pb}, \mathrm{Sr}$ and $\mathrm{Nd}$ in oceanic rocks requires at least four distinct mantle components (White, 1985; Zindler and Hart, 1986a; Allègre et al., 1987). The geographic distribution of these components is largely inferred from the regional patterns in erupted products. For example, Hart (1984) identified a geographically coherent isotope anomaly ("Dupal") which appears to encircle the globe near $30^{\circ} \mathrm{S}$, and is characterized by high ${ }^{87} \mathrm{Sr} /{ }^{86} \mathrm{Sr},{ }^{207} \mathrm{~Pb} /{ }^{204} \mathrm{~Pb}$ and ${ }^{208} \mathrm{~Pb} /{ }^{204} \mathrm{~Pb}$ relative to average values for the northern hemisphere. Other explanations for isotope differences often call upon differences in the efficiency of magmatic processes in eradicating variability in the underlying mantle (Cohen and O'Nions, 1982a; Allègre et al., 1984; Galer and O'Nions, 1986). Understanding the processes associated with magma genesis has therefore become particularly important for deciphering mantle heterogeneity and the temporal evolution of volcanoes. Studies of Th/U isotope disequilibrium in oceanic rocks have provided some constraints on these processes (Allègre and Condomines, 1982; Newman et 
al., 1983; McKenzie, 1985a), and of ten imply time scales of $\sim 10^{4}$ to $10^{5}$ years since melt separation from the source region.

\subsection{He and $\mathrm{Pb}$ Isotope Systematics}

${ }^{3} \mathrm{He}$ is a good indicator of the presence of juvenile volatiles within the earth, and therefore provides a tracer of primitive mantle material (Craig and Lupton, 1976; Kurz et al., 1982a). In a closed system the isotope evolution of helium is coupled to the isotope evolution of lead by virtue of their common radioactive parents ${ }^{238} \mathrm{U}$, ${ }^{235} \mathrm{U}$ and ${ }^{232} \mathrm{Th}$ (Fig. 1.1). In some cases, He isotope signatures can be expected to be ambiguous, due to a high degree of incompatibility in solid silicate phases, potential transport by mantle metasomatic fluids, and relatively rapid accumulation of ${ }^{4} \mathrm{He}$ from radioactive decay of $U$ and Th in outgassed source regions (Condomines et al., 1983; Zindler and Hart, 1986b). Furthermore, multi-stage histories appear to be common features in the $\mathrm{Pb}$ isotope evolution of oceanic volcanic rocks (Allègre et al., 1980), and these might perturb simple He- $\mathrm{Pb}$ relationships. In order to address these problems, this work has focused on measuring He and $\mathrm{Pb}$ isotopes in the same samples, because isotopic variability can be significant even between individual rocks from the same sample suite.

Reconstructing the temporal evolution of $\mathrm{He}$ and $\mathrm{Pb}$ isotopes in the source regions of oceanic volcanoes is complicated by three effects. Firstly, He is produced on a relatively rapid time scale following eruption of lavas with high $U$ and Th contents such as alkali basalts, making it difficult to deduce He-Pb relationships in older rocks. Secondly, fractionation proccesses which occur during the generation of 


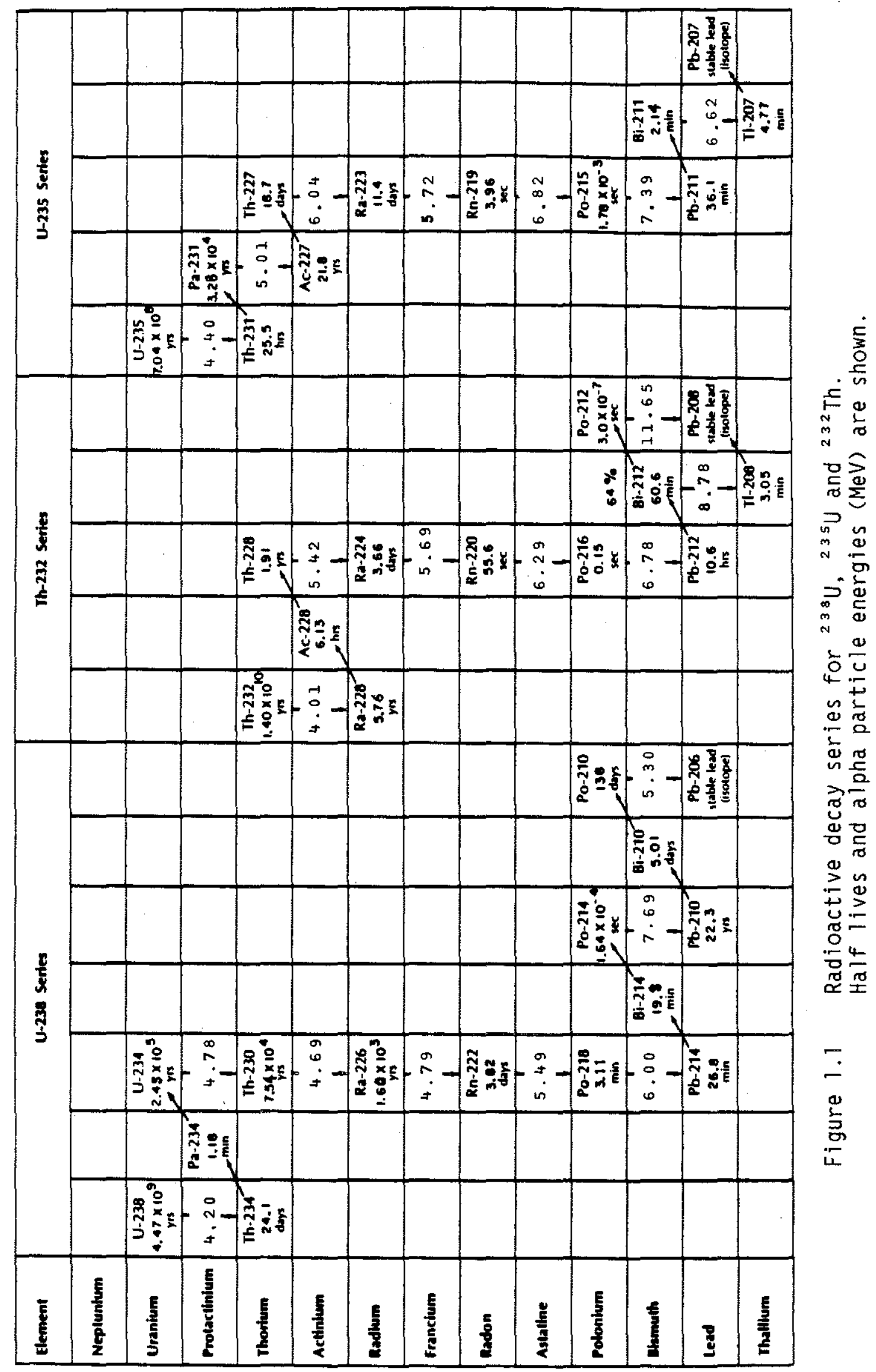


basaltic melts can sometimes produce relatively high $\left(U_{+} T h\right) / H e$ magmas. Subsequent pre-eruptive radiogenic ingrowth of ${ }^{4} \mathrm{He}$ during transit from the mantle source region and residence in magma chambers can obscure primary He-Pb relationships. Thirdly, multi-stage fractionation of $(U+T h) / H e, U / P b$ and $T h / P b$ and convective mixing in the mantle source regions further complicate simple relationships. Aspects of each of these problems are addressed sequentially in chapters $3-6$. The results have implications for the chemical evolution of volcanoes and the suboceanic mantle. These include the nature of temporal evolution of young seamounts inferred from a geochronologic study of young alkali basalts using the $\left(U_{+} T h\right) / H e$ method. They also relate to magma genesis beneath the ocean lithosphere, and to the evolutionary history of the source regions of mid-ocean ridges, seamounts and oceanic islands.

The time scales producing isotope variations in $\mathrm{He}$ and $\mathrm{Pb}$ are quite different, due to the relatively rapid production of ${ }^{4} \mathrm{He}$ during $\alpha$-particle emission. The fractional lowering of ${ }^{3} \mathrm{He} /{ }^{4} \mathrm{He}$ by radiogenic ingrowth in a closed system is a function of four parameters: 1) the $(U+T h) /{ }^{3} \mathrm{He}$ atom ratio, 2) the ${ }^{3} \mathrm{He} /{ }^{4} \mathrm{He}$ radiogenic production ratio (typically $10^{-8}$ for basalts and $10^{-7}$ for granites; Morrison and Pine, 1955; Andrews, 1985), 3) the initial ${ }^{3} \mathrm{He} /{ }^{4} \mathrm{He}$ and 4 ) time. These parameters are related by

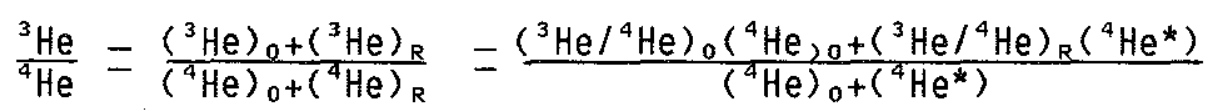

where subscripts $R$ and 0 correspond to radiogenic and initial conditions, respectively, and ${ }^{4} \mathrm{He}{ }^{*}$ is the amount of radiogenic ${ }^{4} \mathrm{He}$ in the 
system. The number of ${ }^{4} \mathrm{He}$ atoms produced at secular equilibrium during time $t$ is given by

$$
{ }^{4} H e^{*}=8\left[{ }^{238} U\left(e^{\lambda} 8^{t}-1\right)\right]+7\left[235 U\left(e^{\lambda} 5^{t}-1\right)\right]+6\left[232 \operatorname{Th}\left(e^{\lambda} 2^{t}-1\right)\right]
$$

where $\lambda^{\prime} s$ are the respective decay constants $\left(\lambda_{8}=1.55125 \times 10^{-10}\right.$ $\mathrm{y}^{-1}, \lambda_{2}=9.8485 \times 10^{-10} \mathrm{y}^{-1}$ and $\lambda_{2}=4.9475 \times 10^{-11} \mathrm{y}^{-1}$;

Steiger and Jager, 1977) and ${ }^{238} \mathrm{U},{ }^{235} \mathrm{U}$ and ${ }^{232} \mathrm{Th}$ are the number of parent atoms. The fractional lowering of the He isotopic ratio $\left(\mathrm{F}=\left({ }^{3} \mathrm{He} /{ }^{4} \mathrm{He}\right) /\left({ }^{3} \mathrm{He} /{ }^{4} \mathrm{He}\right)_{0}\right)$ is

$$
F=\frac{1+(.9927 \mathrm{~J} / \mathrm{C})\left({ }^{3} \mathrm{He} /{ }^{4} \mathrm{He}\right)_{R}\left(\mathrm{U} /{ }^{3} \mathrm{He}\right)_{0}}{1+(.9927 \mathrm{~J} / \mathrm{C})\left({ }^{3} \mathrm{He} /{ }^{4} \mathrm{He}\right)_{0}\left(\mathrm{U} /{ }^{3} \mathrm{He}\right)_{0}}
$$

where 0.9927 is the present day natural abundance of ${ }^{238} \mathrm{U}, J$ is ${ }^{*} \mathrm{He}$ produced per atom of ${ }^{238} \mathrm{U}$ (calculated from 1.2), and $c=$ $\left(e^{\lambda} B^{t}+(1 / 137.8) e^{\lambda 5^{t}}\right) /(1+1 / 137.8)$ converts present [U] to initial values. (When $U$ is measured in ppm and ${ }^{3} \mathrm{He}$ in cCSTP/g, atomic $\mathrm{U} /{ }^{3} \mathrm{He}$ is obtained by multiplying by $(22414 / 238) \times 10^{-6}$.) $F$ is shown as a function of time in Fig. 1.2 and 1.3 for different initial $\mathrm{U} /{ }^{3} \mathrm{He}$, and selected values for Th/U, $\left({ }^{3} \mathrm{He} /{ }^{4} \mathrm{He}\right)_{R}$ and initial ${ }^{3} \mathrm{He} /{ }^{4} \mathrm{He}$. As one example, similar to the case of radiogenic ingrowth in seamount alkalic magmas (discussed in chapter 3 ), when $\left(U /{ }^{3} \mathrm{He}\right)_{0} \simeq 2 \times 10^{9}$, Fig. 1.2 shows that ${ }^{3} \mathrm{He} /{ }^{4} \mathrm{He}$ decreases to $\sim 62 \%$ and $\sim 16 \%$ of its initial value in $10^{4}$ and $10^{5}$ years, respectively. Fig. 1.3 illustrates the effect of radiogenic ${ }^{4} \mathrm{He}$ production over the age of the Earth for a primordial ${ }^{3} \mathrm{He} /{ }^{4} \mathrm{He}=100 \mathrm{R}_{\mathrm{A}}$. In this case, if $\left(\mathrm{U} /{ }^{3} \mathrm{He}\right)_{0}=2000$ (curve 3 in Fig. 1.3), a closed system chondritic Earth (20 ppb U; Th/U 3.8) would have present day ${ }^{3} \mathrm{He} /{ }^{4} \mathrm{He}$ near $34 \mathrm{R}_{\mathrm{A}}$, similar to the highest values measured in submarine volcanic rocks (Kurz 
Figure 1.2 Fractional lowering of ${ }^{3} \mathrm{He} /{ }^{4} \mathrm{He}$ by radiogenic ingrowth in a closed system. Numbers next to curves correspond to different initial $U /^{3} \mathrm{He}$ (atom ratio);

$\left(U /{ }^{3} \mathrm{He}\right)_{0} \quad[U], \mathrm{ppm}[\mathrm{He}], \mathrm{ccSTP} / \mathrm{g}$

\begin{tabular}{|c|c|c|c|}
\hline & $2.03 \times 10^{7}$ & 0.3 & $10^{-7}$ \\
\hline & $6.78 \times 10^{7}$ & 1.0 & $10^{-7}$ \\
\hline & $2.03 \times 10^{8}$ & $0.3,3.0$ & $10^{-8}, 10^{-7}$ \\
\hline & $6.78 \times 10^{8}$ & 1.0 & $10^{-8}$ \\
\hline & $2.03 \times 10^{9}$ & $0.3,3.0$ & $10^{-9}, 10^{-8}$ \\
\hline & $6.78 \times 10^{9}$ & 1.0 & $10^{-9}$ \\
\hline & $2.03 \times 10^{10}$ & 3.0 & $10^{-9}$ \\
\hline
\end{tabular}

For cases shown $\mathrm{Th} / \mathrm{U}=3$, the radiogenic ${ }^{3} \mathrm{He} /{ }^{4} \mathrm{He}$ production ratio $=10^{-8}$, and initial ${ }^{3} \mathrm{He} /{ }^{4} \mathrm{He}=10 \mathrm{R}_{\mathrm{A}}$. 


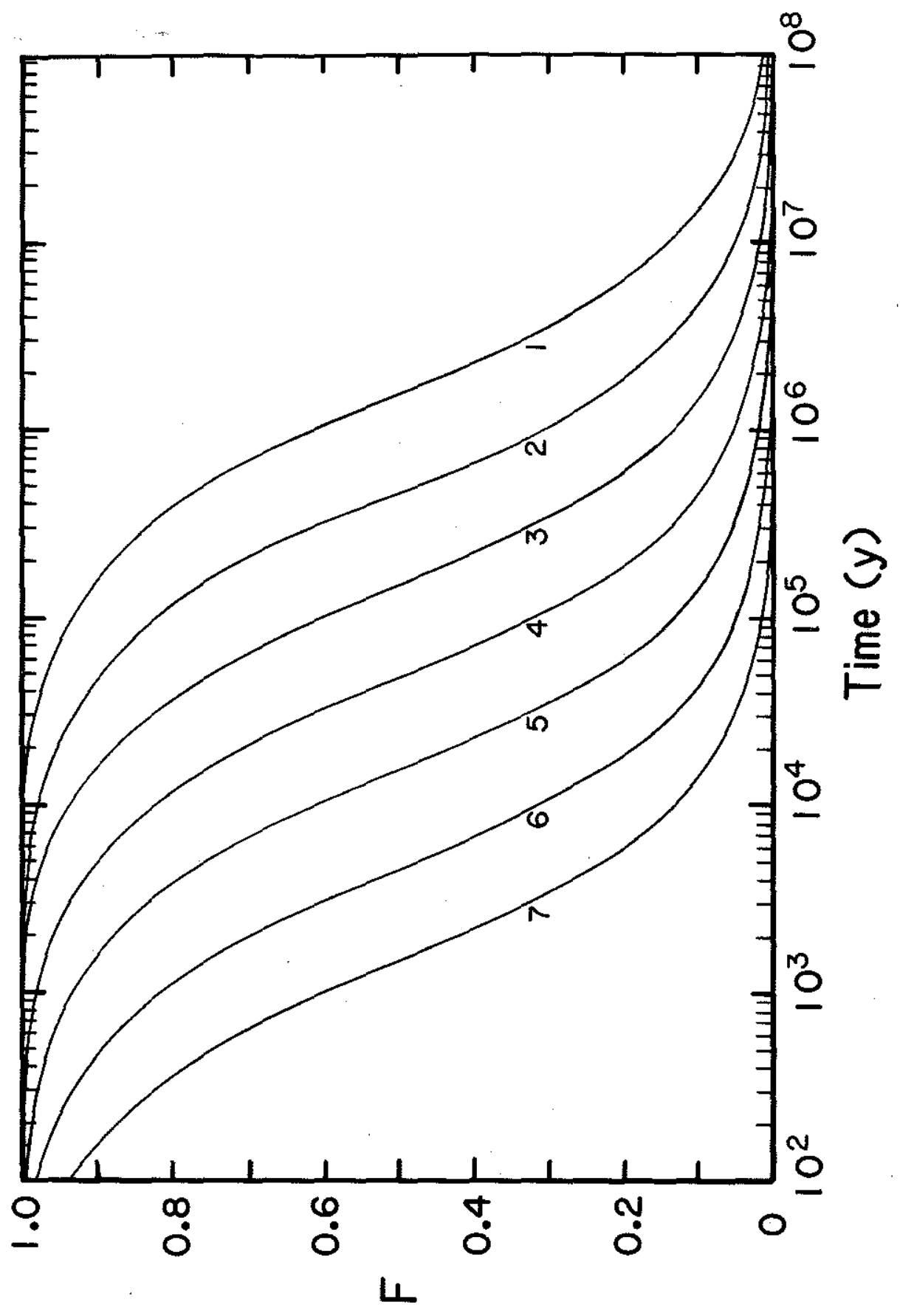


Figure 1.3 Fractional lowering of ${ }^{3} \mathrm{He} /{ }^{4} \mathrm{He}$ over the age of the Earth for a primordial ${ }^{3} \mathrm{He} /{ }^{4} \mathrm{He}=100 \mathrm{R}_{\mathrm{A}}, \mathrm{Th} / \mathrm{U}=3.8$ and no radiogenic production of ${ }^{3} \mathrm{He}$. Range of ${ }^{3} \mathrm{He} /{ }^{4} \mathrm{He}$ in diamonds from Ozima and Zashu (1983) and Kurz et al. (1987a). Chondritic Earth has ${ }^{3} \mathrm{He} /{ }^{4} \mathrm{He} \simeq 100 \mathrm{R}_{\mathrm{A}}$, as measured in gas-rich meteorites (Black, 1972) and $U \simeq 20$ ppb (Hart and Zindler, 1987).

\begin{tabular}{|c|c|c|}
\hline$\left(\mathrm{U} /{ }^{3} \mathrm{He}\right)_{0}$ & [U], $\mathrm{ppb}$ & $\begin{array}{l}\text { Examples } \\
{\left[{ }^{3} \mathrm{He}\right], \text { ccSTP/g }}\end{array}$ \\
\hline $\begin{array}{r}200 \\
600 \\
2000 \\
6000 \\
2 \times 10^{4} \\
2 \times 10^{5} \\
6 \times 10^{5} \\
2 \times 10^{6} \\
6 \times 10^{6} \\
2 \times 10^{7}\end{array}$ & 20 & $\begin{array}{r}10^{-8} \\
3.3 \times 10^{-9} \\
10^{-9} \\
3.3 \times 10^{-10} \\
10^{-10} \\
10^{-11} \\
3.3 \times 10^{-12} \\
10^{-12} \\
3.3 \times 10^{-13} \\
10^{-13}\end{array}$ \\
\hline
\end{tabular}




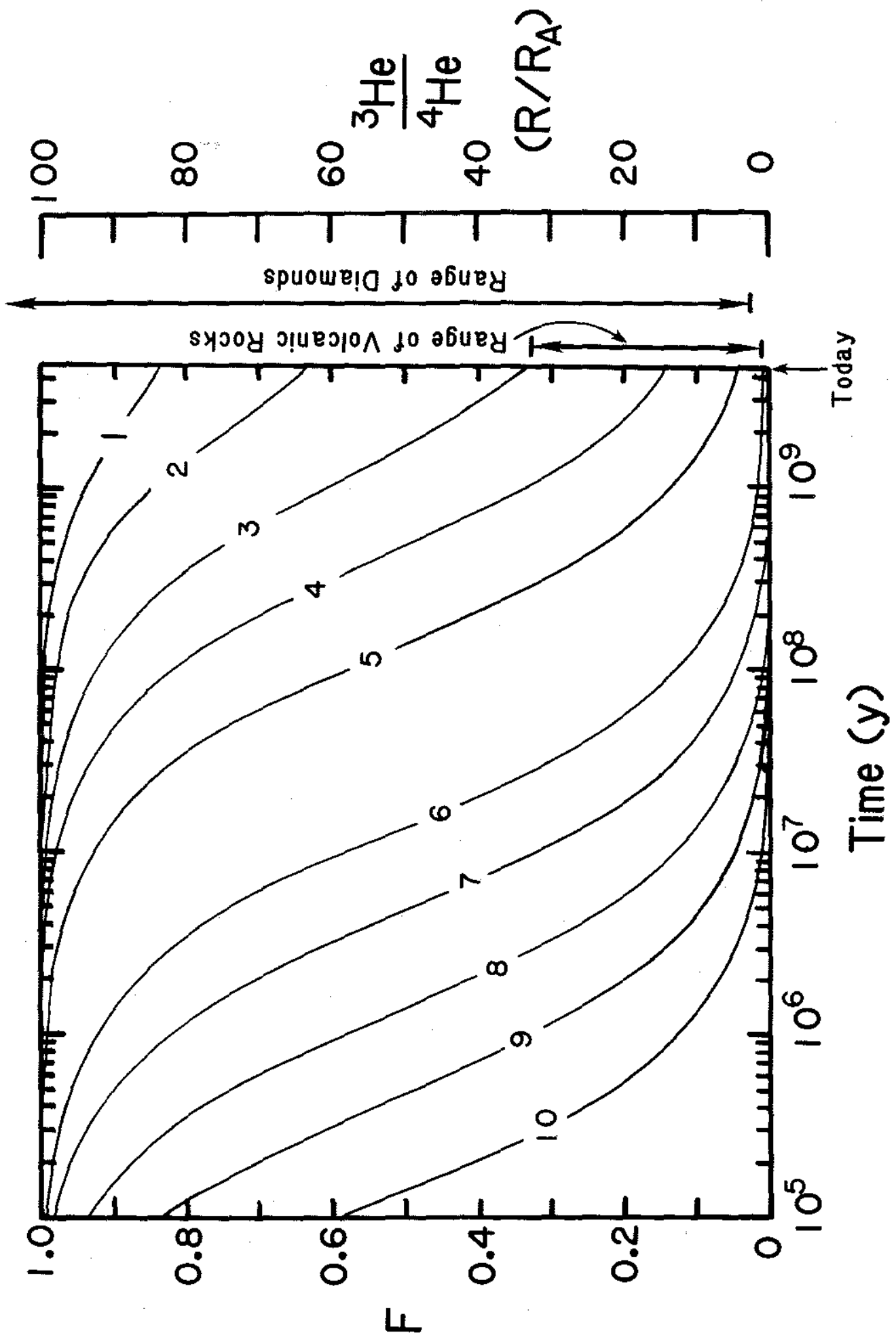


et al., 1983). Thus, ${ }^{3} \mathrm{He} /{ }^{4} \mathrm{He}$ can be used in favorable cases to study processes which occur on a variety of time scales.

$\mathrm{Pb}$ isotope evolution in a closed system is a function of 1) $\left.\left.{ }^{238} \mathrm{U} / /^{204} \mathrm{~Pb}(\mu), 2\right){ }^{232} \mathrm{Th} /{ }^{238} \mathrm{U}(\kappa), 3\right)$ initial $\mathrm{Pb}$ isotopic composition and 4) time. Isotopic evolution is described by (Gale and Mussett, 1973; Faure, 1977)

$$
\begin{aligned}
& \left({ }^{206} \mathrm{~Pb} /{ }^{204} \mathrm{~Pb}\right)_{t}=\left({ }^{206} \mathrm{~Pb} /{ }^{204} \mathrm{~Pb}\right)_{0}+\mu\left(e^{\lambda_{8} T_{0}}-e^{\lambda_{8}} \mathrm{t}^{t}\right) \\
& \left({ }^{207} \mathrm{~Pb} / 204 \mathrm{~Pb}\right)_{t}=\left({ }^{207} \mathrm{~Pb} /{ }^{204} \mathrm{~Pb}\right)_{0}+(\mu / 137.88)\left(e^{\lambda_{5} T_{0}}-e^{\lambda_{5}}\right) \\
& \left({ }^{208} \mathrm{~Pb} /{ }^{204} \mathrm{~Pb}\right)_{t}=\left({ }^{208} \mathrm{~Pb} /{ }^{204} \mathrm{~Pb}\right)_{0}+\mu \kappa\left(e^{\lambda_{2} T_{0}}-e^{\lambda_{2}{ }^{t}}\right)
\end{aligned}
$$

where $T_{0}$, the age of the earth, is taken to be $4.55 \mathrm{Ga}$. The effects for selected values of $\mu(=7,8$ and 9$)$ and $\kappa(=2,3,4)$ are illustrated in Fig. 1.4 and 1.5 .

As discussed previously by many authors, the $\mathrm{Pb}$ isotope systematics of oceanic rocks indicate that the mantle source regions may have undergone complex, multistage histories involving ancient $(\sim 2 \mathrm{Ga}) \mathrm{Pb}$ removal to some other reservoir, possibly to either the earth's core or the lower continental crust (Tatsumoto, 1966; Gast, 1969; Tatsumoto, 1978; O'Nions et a1., 1979; Allègre et al., 1980). Pb isotope compositions of nearly all oceanic rocks plot to the right of the geochron and suggest time-integrated $\mu$ values between 8-9. MORB are characterized by time-integrated $\kappa$ values in the range of $3.45-3.90$ (Galer and O'Nions, 1985; White et al., 1987), while $\alpha$ values in ocean island basalts (deduced from the slope of ${ }^{208} \mathrm{~Pb} /{ }^{204} \mathrm{~Pb} \mathrm{vs}$. ${ }^{206} \mathrm{~Pb} /{ }^{204} \mathrm{~Pb}$ ) are slightly higher, between 3.8-4.2 (Oversby and Gast, 1968; Galer and O'Nions, 1985) and close to values estimated for the "bulk earth" (Chase, 1981; Allègre et al., 1986a). Present-day $\mathrm{k}$ in 


$$
\begin{aligned}
& \text { Figure 1.4. }{ }^{207} \mathrm{~Pb} /{ }^{204} \mathrm{~Pb}-{ }^{206} \mathrm{~Pb} /{ }^{204} \mathrm{~Pb} \text { evolution in the earth } \\
& \text { for }{ }^{238} \mathrm{U} /{ }^{204} \mathrm{~Pb}(\mu) \text { of } 7,8 \text { and } 9.4 .55 \text { Ga geochron } \\
& \text { is shown for reference, and tick marks along the } \mu=8 \\
& \text { curve show } 0.5 \mathrm{Ga} \text { intervals. Primordial } \mathrm{Pb} \text { compositions } \\
& \text { are from Tatsumoto et al. (1973). }
\end{aligned}
$$




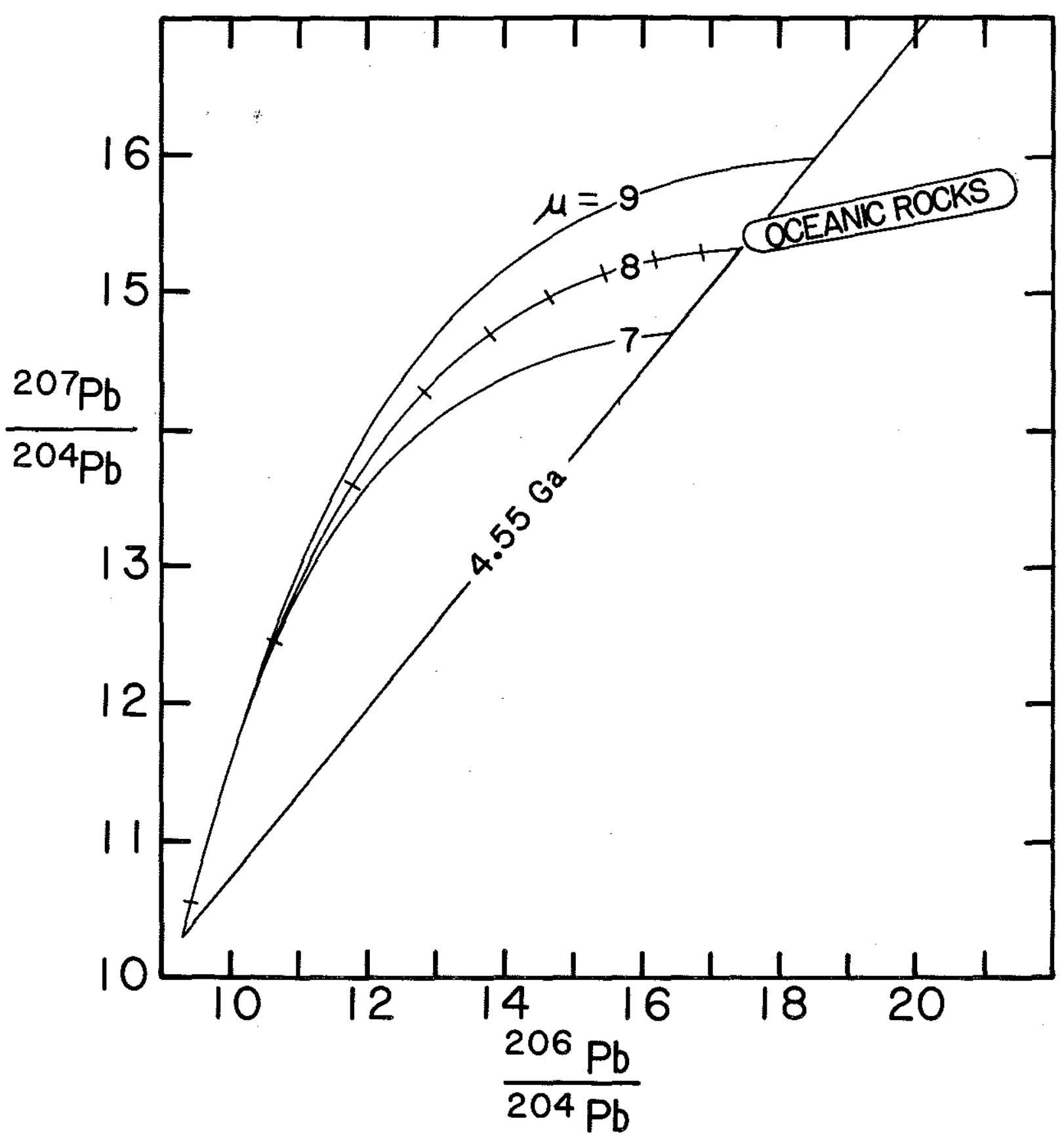




\section{Figure $1.5{ }^{208} \mathrm{~Pb} /{ }^{204} \mathrm{~Pb}-{ }^{206} \mathrm{~Pb} /{ }^{204} \mathrm{~Pb}$ evolution in the earth for $\mu=8$ and ${ }^{232} T h /^{238} U(K)$ of 2,3 and 4 . Time scale along upper axis gives ${ }^{206} \mathrm{~Pb} /{ }^{204} \mathrm{~Pb}$ evolution with time. Primordial values for ${ }^{206} \mathrm{~Pb} /{ }^{204} \mathrm{~Pb}$, ${ }^{207} \mathrm{~Pb} /{ }^{204} \mathrm{~Pb}$ and ${ }^{208} \mathrm{~Pb} /{ }^{204} \mathrm{~Pb}$ are $9.307,10.294$ and 29.476 , respectively (Tatsumoto et al., 1973).}




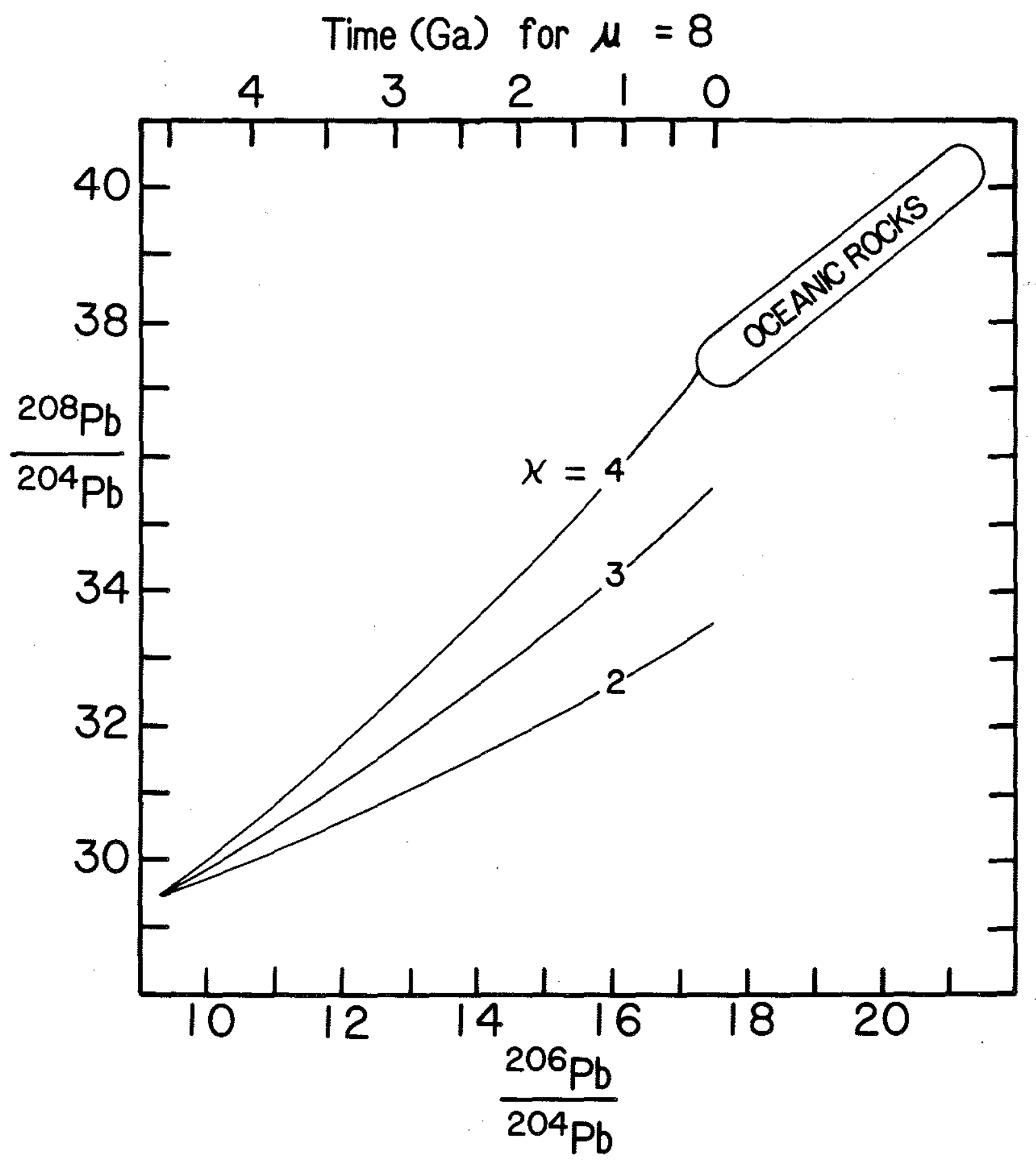


the depleted upper mantle, estimated from $\left({ }^{232} \mathrm{Th} /{ }^{230} \mathrm{Th}\right)$ activity ratios in MORB is somewhat lower ( 2.5 ; Allègre and Condomines, 1982; Newman et al., 1983) while present day $k$ in the source region of OIB ranges between $3.0-3.8$ (Allègre and Condomines, 1982; Newman et a1., 1984). Galer and O'Nions (1985) suggested that if the mantle is viewed as a depleted reservoir overlying a primitive one, the apparent contradiction in $k$ for the depleted mantle implies that the residence time of $\mathrm{Pb}$ in the upper mantle is less than $\sim 600 \mathrm{~m} . \mathrm{y}$.. Residence times: for $U$ and Th would be similar to $\mathrm{Pb}$ given their high degree of incompatibility in mantle silicate phases. Depletion of Th relative to $U$ and $\mathrm{Pb}$ is consistent with present knowledge of $U$, Th and $\mathrm{Pb}$ distribution coefficients between silicate melts and crystals. Bulk distribution coefficients for $U$ and Th between major silicate phases and melts are $\simeq .002-.03$; (Seitz, 1973; Tatsumoto, 1978; Benjamin et al., 1980); $D_{P_{b}}$ for clinopyroxene-melt is $\sim 0.01$ (Watson et al., 1987). Th also appears to be more incompatible than $U$ based on the systematic increase in Th/ as a function of [Th] for MORB glasses (Jochum et al., 1983). The fact that nearly all oceanic rocks (some Indian Ocean MORBs and Walvis Ridge rocks are exceptions) plot to the right of the geochron suggests that non-magmatic processes, in addition to melt removal, may have served to increase $\mathrm{U} / \mathrm{Pb}$ in the residual mantle during early stages of Earth evolution (Zindler and Hart, 1986a; Newsom et al., 1986). The He isotope characteristics of mantle material characterized by high U/Pb (HIMU), and the implications for the nature of source materials are discussed in chapter 6 . 
When parent/daughter fractionation occurs at a discrete time $t$ in the past (the episodic evolution model), and the derivatve system remains closed since that time, the slope on the ${ }^{207} \mathrm{~Pb} /{ }^{204} \mathrm{~Pb}-{ }^{206} \mathrm{~Pb} /{ }^{204} \mathrm{~Pb}$ and ${ }^{208} \mathrm{~Pb} /{ }^{204} \mathrm{~Pb}-{ }^{206} \mathrm{~Pb} /{ }^{204} \mathrm{~Pb}$ diagrams is related to $\mathrm{t}$ by,

$$
\begin{aligned}
& \Delta\left({ }^{207} \mathrm{~Pb} /{ }^{206} \mathrm{~Pb}\right)=\left(e^{\lambda_{5}}-1\right) / 137.88\left(e^{\lambda^{t}}-1\right) \\
& \Delta\left({ }^{208} \mathrm{~Pb} / 206 \mathrm{~Pb}\right)=\kappa\left(e^{\lambda_{2}}-1\right) /\left(e^{\lambda} 8^{t}-1\right)
\end{aligned}
$$

where $\kappa$ is ${ }^{232} \mathrm{Th} /{ }^{238} \mathrm{U}$ during the last stage. Such time interpretations are often too simplistic because continuous, open system evolution and convective mixing of different components within the Earth's mantle can also produce linear arrays on $\mathrm{Pb}-\mathrm{Pb}$ diagrams (Allègre et al., 1980). In chapter $4 \mathrm{~Pb}-\mathrm{Pb}$ arrays for seamount lavas in the East Pacific are discussed with respect to convective mixing in the mantle.

\subsection{Helium and Earth's Thermal Regime}

Because $U$ and Th provide approximately three-fourths of the earth's internal heat production (Wasserburg et al., 1964; Table 1.1), the isotope evolution of $\mathrm{He}$ in the earth is directly related to its thermal history. The relationship between helium and heat has been discussed in detail by $0^{\prime} N i o n s$ and Oxburgh (1983). The theoretical production ratio of ${ }^{4} \mathrm{He} / \mathrm{heat}$ is approximately $4 \times 10^{12}$ atom/cal (Table 1.1). O'Nions and Oxburgh (1983) used this relationship in conjunction with flux estimates for ${ }^{3} \mathrm{He},{ }^{4} \mathrm{He}$ and heat in the ocean basins and in continental areas to infer aspects concerning the thermal regime of the earth's interior. They showed that the oceanic heat flux $\left(\sim 20 \times 10^{19}\right.$ cal/y) is accompanied by a deficiency in ${ }^{4} \mathrm{He}$ by about a factor of 15 relative to the production ratio, and concluded that only a small 
Table 1.1.

Heat and Helium Poduction by Radioactive Nuclides

\begin{tabular}{|c|c|c|}
\hline I sotope & $\begin{array}{l}\text { Heat Production } \\
\left(10^{-14} \mathrm{cal} / \mathrm{g}-\mathrm{sec}-\mathrm{ppm}\right)\end{array}$ & $\begin{array}{l}\text { Helium Production } \\
\text { (atom/g-sec-ppm) }\end{array}$ \\
\hline $\begin{array}{l}238 \mathrm{U}(99.27 \%) \\
235 \mathrm{U}(0.72 \%) \\
\mathrm{U}(\text { natural) } \\
2{ }^{32} \mathrm{Th}(100 \%) \\
{ }^{40} \mathrm{~K}(0.0119 \%) \\
\mathrm{K}(\text { natural) } \\
{ }^{87} \mathrm{Rb}(27.8 \%) \\
\mathrm{Rb} \text { (natural) }\end{array}$ & $\begin{array}{l}2.25 \\
13.6 \\
2.32 \\
0.621 \\
0.693 \\
8.37 \times 10^{-5} \\
5.02 \times 10^{-3} \\
1.39 \times 10^{-3}\end{array}$ & $\begin{array}{l}0.0997 \\
0.562 \\
0.103 \\
0.0245 \\
--.-- \\
--\cdots- \\
----\end{array}$ \\
\hline
\end{tabular}

Heat production from Stacey (1970).

Values for $U$ and $T h$ include heat production by daughters in secular equilibrium. At secular equilibrium, for $T h / U=3$, the ${ }^{4} \mathrm{He} /$ heat production ratio is $\sim 4 \times 10^{12}$ atom/cal. 
fraction of the heat flux results from radiogenic heating within the depleted upper mantle (with a large component stemming from the deeper mantle), and that heat loss from the earth's interior is characterized by a time constant of about $2 \times 10^{9} \mathrm{y}$. Either the lithosphere or (as suggested by $\mathrm{O}^{\prime} \mathrm{Ni}$ ions and Oxburgh, 1983) the upper/lower mantle boundary acts as a more effective barrier to He loss than to heat. Because most of the ${ }^{235} U$ decayed early in the history of the earth, the coupling of $\mathrm{He}$ and $\mathrm{Pb}$ isotopes may provide information on the thermal history of the Earth's interior if ancient $\left(\sim 2 \times 10^{9} y\right)$ mantle components can be identified unambiguously, for example by elevated ${ }^{207} \mathrm{~Pb} /{ }^{204} \mathrm{~Pb}$.

Problems remain with our understanding of the coupling of oceanic He and heat fluxes. The oceanic ${ }^{3} \mathrm{He}$ flux ( 4 atoms $/ \mathrm{cm}^{2}-\mathrm{sec}$ ) was computed from the deep ocean integrated anomaly in $\delta\left({ }^{3} \mathrm{He}\right)$ and abyssal Pacific residence time, estimated from deep water ${ }^{14} \mathrm{C}$ (Craig et al., 1975). Jenkins et al. (1978) used the measured ${ }^{3} \mathrm{He} /$ temperature relation in Galapagos vent waters (with temperatures up to $\sim 15^{\circ} \mathrm{C}$ ) and the oceanic ${ }^{3} \mathrm{He}$ flux to show that the convective heat flux at mid-ocean ridges was $\sim 5 \times 10^{19} \mathrm{cal} / \mathrm{y}$, in agreement with independent heat flow estimates (Williams and VonHerzen, 1975). However, the ${ }^{4} \mathrm{He} /$ heat ratio in these fluids $\left(1.2 \times 10^{12}\right.$ atom/cal $)$ is only $30 \%$ of the theoretical production ratio. Merlivat et al. (1987) showed that ${ }^{4} \mathrm{He} /$ heat ratios in high temperature (up to $\sim 350^{\circ} \mathrm{C}$ ) vent waters from the East Pacific Rise at $13^{\circ} \mathrm{N}$ are somewhat higher, ranging between $\sim 1.7-3.5 \times 10^{12}$ atom/cal, and suggested that diffusive differences between He and heat produce lower He/heat ratios upon subsequent cooling. It also appears some other process serves to modulate He/heat flux ratios at mid-ocean 
ridges. One complicating factor may also be the possibility that He and heat are transported differently into the region of melt generation beneath ridges. This question is partially addressed in chapter 4 .

\subsection{Isotope Signatures and Seamount Evolution}

${ }^{3} \mathrm{He} /{ }^{4} \mathrm{He}$ is generally lower at islands erupting alkali basalts compared to those erupting tholeiites (Kurz et al., 1982a). The origin of low ${ }^{3} \mathrm{He} /{ }^{4} \mathrm{He}$ ratios in ocean island basalts is uncertain; it may result from low magma throughput and "aging" within volcanic systems, or it may reflect a source signature. Seamounts offer an opportunity to test systematic isotopic differences between tholeites and alkali basalts, because these rock types are often erupted on individual volcanoes. For example, at Loihi seamount ${ }^{3} \mathrm{He} /{ }^{4} \mathrm{He}$ is systematically lower in alkali basalts compared to tholei ites, and both rock types show decreases in ${ }^{3} \mathrm{He} /{ }^{4} \mathrm{He}$ with increasing volcano volume and age along the Hawailan hotspot chain (Kurz et al., 1983; Rison and Craig, 1983). Such systematics demonstrate the utility of ${ }^{3} \mathrm{He} /{ }^{4} \mathrm{He}$, in conjunction with petrologic and tectonic models of seamount evolution, to address questions regarding spatial and temporal variability of seamount chemistry.

Much of what is known about the evolution and chemical composition of seamounts has been inferred from studies of oceanic islands, which appear to grow episodically over $10^{6}$ to $10^{7}$ year time scales. Menard (1969) suggested that seamounts near flanks of mid-ocean ridges also grow over similar time periods, but that total magma supply is usually insufficient to build islands within the first ten million years of seafloor 
subsidence. Along the East Pacific Rise, seamounts are nearly absent in the $\sim 1 \mathrm{~km}$ wide neovolcanic zone, but they are abundant just outside it, where they are sometimes broken by ridge parallel faults. Thus their formation usually begins just outside the neovolcanic zone, but their development appears linked to ridge axis volcanic and tectonic processes. The chemical compositions of lavas erupted at seamounts from both fracture zone and normal crustal settings appear to be related to volume and age of the respective seamounts, though not in a simple manner (Batiza, 1977, 1980; Batiza and Vanko, 1984). Small volcanoes formed near ridge crests are composed of tholeites similar in chemistry to normal MORB, and are later capped by alkali basalts as they are moved away from the ridge (Fig. 1.6).

The number of off-ridge non-hotspot central volcanoes (i.e., small seamounts not members of linear chains) correlates with the inverse square root of lithospheric age, in a manner resembling oceanic heat flow (Batiza, 1982). This suggests that the development of the underlying lithosphere influences seamount abundance and evolution. It is also likely that non-hotspot volcanoes are preferentially located on fracture zones, as evidenced by small offsets in magnetic anomalies in the vicinity of many seamounts (Batiza and Vanko, 1983; McNutt and Batiza, 1981). However, the effects of lithospheric thickening in different tectonic environments are difficult to assess, because it is not clear whether volcanism is focused at fracture zones because they provide suitable conduits, or because stress-release melting occurs in the 1ithosphere. Questions concerning source regions and the temporal 


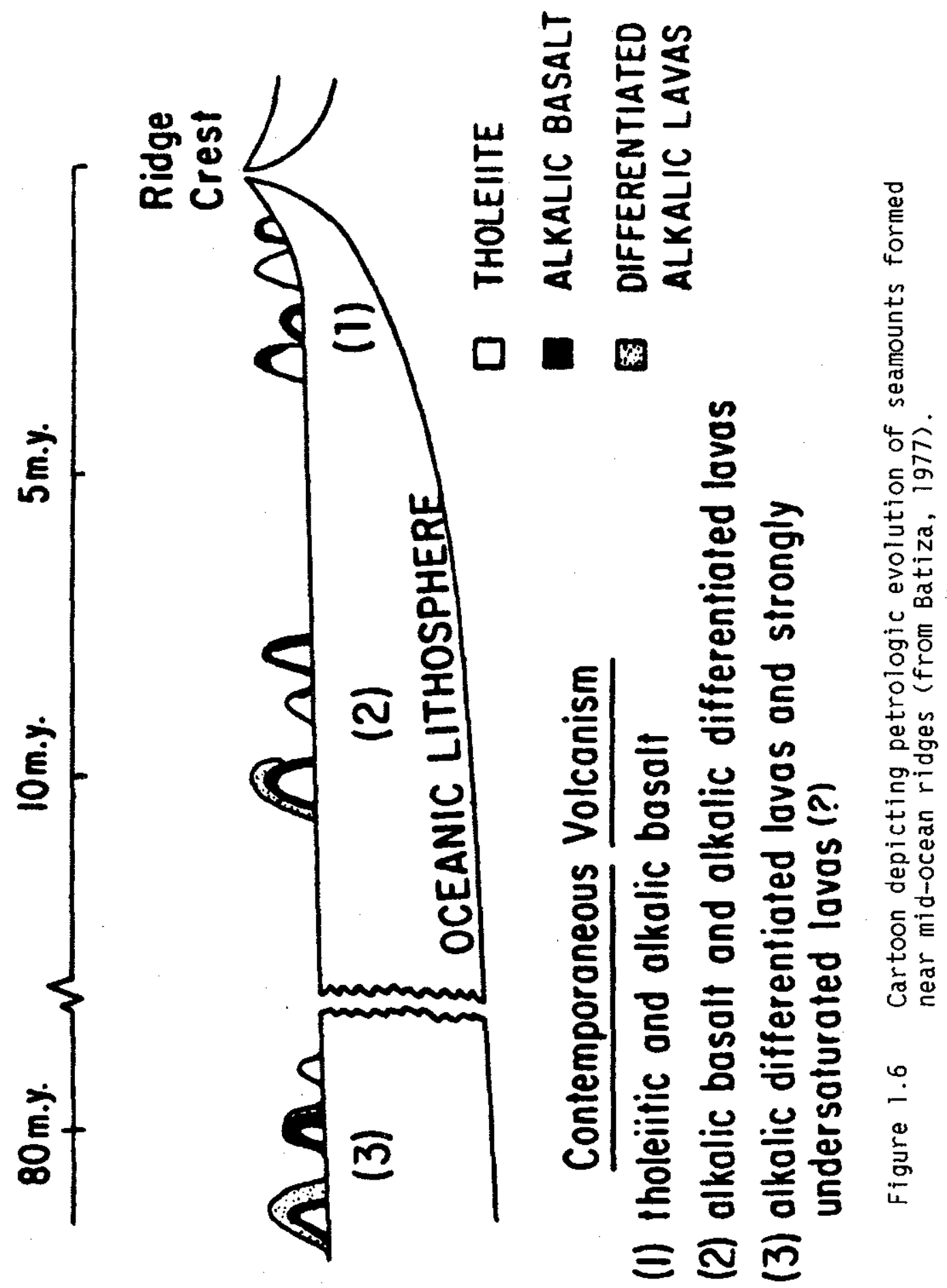


evolution of the conduit system and magmatic reservoirs are inextricably linked to the processes of lithospheric thickening. Seamount evolution also appears to involve smaller degrees of partial melting of isotopically heterogeneous mantle at progressively greater distances off-axis. The isotopic diversity of lavas erupted at small seamounts indicates that these heterogeneities are long lived $\left(\sim 10^{8}\right.$ years $)$ and have scale lengths on the order of kilometers (Batiza and Vanko, 1984; Zindler et al., 1984).

In chapter 3 , the temporal evolution of seamount 6 alkali basalts over the last 300,000 years is studied using $(U+T h) /{ }^{3}$ He ages determined from isotope disequilibrium between helium trapped in vesicles and dissolved in the glass phase. In chapter 4, $\mathrm{He}, \mathrm{Pb}, \mathrm{Sr}$ and $\mathrm{Nd}$ isotope results from young seamounts are discussed with respect to magma genesis and mantle heterogeneity beneath the East Pacific.

\subsection{Helium and Lead Isotopes in South Atlantic MORB} and Lavas from the Island of St. Helena

Geochemically distinct provinces in the sub-oceanic mantle are also inferred from regional mapping of the $\mathrm{Pb}, \mathrm{Sr}, \mathrm{Nd}$ and He isotope distributions in basalts erupted along mid-ocean ridges. Dupré and Allègre (1983), Hamelin and Allègre (1985a) and Hamelin et al. (1985b) showed that the mantle underlying the Indian Ocean and parts of the South Atlantic has distinctly higher ${ }^{87} \mathrm{Sr} /{ }^{86} \mathrm{Sr}$ and ${ }^{208} \mathrm{~Pb} /{ }^{204} \mathrm{~Pb}$ (at similar values of ${ }^{206} \mathrm{~Pb} /{ }^{204} \mathrm{~Pb}$ ) than the mantle underlying the North Atlantic and East Pacific. They inferred that these domains have 
remained effectively separated for geologically significant time periods $\left(\sim 10^{9} \mathrm{y}\right)$. They suggested that the results can be viewed in light of a contamination model, where the depleted MORB mantle (DM) is similar to that beneath the North Atlantic, but has been periodically polluted with different contaminants. These contaminants may have isotopic characteristics similar to the sources for Walvis Ridge (enriched mantle or EM 1 in the terminology of Zindler and Hart, 1986a), Samoa (EM 2) or St. Helena (HIMU). EM 1 may derive from lower continental crust (Hart et al., 1986); similar low $\mathrm{Nd}$ and $\mathrm{Pb}$ isotopic ratios have also been measured in Therzolite xenoliths from East Africa (Cohen et a1., 1984). These xenoliths display a narrow range in ${ }^{3} \mathrm{He} /{ }^{4} \mathrm{He}$, with a mean value of $\sim 6 R_{A}$ (Porcelli et al., 1986), similar to values measured at Tristan da Cunha and Gough Island (Kurz et al., 1982a). Recycled sediments or upper continental crust have been proposed as the source for EM 2 (White, 1985; Zindler and Hart, 1986a; Wright and White, 1986). The origin of HIMU is not clear (Zindler et al., 1982; White, 1985; Hart et al., 1986). These components are not geographically isolated, al though they occur less frequently in the northern hemisphere. For example, Shirey et a1. (1987) have detected EM 1 isotopic structures at the Oceanographer Fracture Zone in the North Atlantic. Isotopic results from Shimada seamount at $17^{\circ} \mathrm{N}$ in the East Pacific (chapter 4) display a significant EM 2 component.

DM (depeleted MORB mantle) and HI 3 (Loihi seamount source) are characterized by ${ }^{3} \mathrm{He} /{ }^{4} \mathrm{He}$ of $\sim 8.4 \mathrm{R}_{\mathrm{A}}$ and $\geq 32 \mathrm{R}_{\mathrm{A}}$, respectively (Kurz et a1., 1982a). EM 1, EM 2 and HIMU are not as well characterized for He isotopes. To the extent that Tristan da Cunha and Gough Island 
reflect an EM 1 signature, this component has ${ }^{3} \mathrm{He} /{ }^{4} \mathrm{He}$ less than MORB (Kurz et a1., 1982a). Within the North Atlantic basin are two provinces with low ${ }^{3} \mathrm{He} /{ }^{4} \mathrm{He}$; the Azores platform region between $33-50^{\circ} \mathrm{N}$ (Kurz et a1., 1982b) and the Mohn's Ridge and Jan Mayen (Poreda et al., 1986; Kurz et al., 1982a). These regions also have elevated ${ }^{87} \mathrm{Sr} /{ }^{86} \mathrm{Sr}$ and $(\mathrm{La} / \mathrm{Sm})_{\mathrm{N}}$. The low ${ }^{3} \mathrm{He} /{ }^{4} \mathrm{He}$ demonstrates that elevated $\mathrm{Sr}$ isotope signatures do not necessarily imply a more primitive mantle source, but rather that either subducted material in the source regions, or multiple enrichment events ("metasomatism") may have led to higher time-integrated $(\mathrm{U}+\mathrm{Th}) /{ }^{3} \mathrm{He}$ and $\mathrm{Rb} / \mathrm{Sr}$.

Chapter 5 presents helium isotope results from a survey of mid-ocean ridge basalt glasses dredged from the South Atlantic, between $0-46^{\circ} \mathrm{S}$, and for phenocrysts in lavas from the island of St. Helena. Most of the MORB samples have been analyzed for $\mathrm{Pb}$ isotopes by Hanan et al. (1986). Whole rock powders from St. Helena were analyzed for $\mathrm{Pb}$ isotopes. ${ }^{3} \mathrm{He} /{ }^{4} \mathrm{He}$ ratios along much of the mid-ocean ridge in the South Atlantic are lower than normal MORB values $\left(\sim 8.4 R_{A}\right)$, and are correlated with $\mathrm{Pb}$ isotopes in specific cases. The He-Pb relationships along the ridge and at St. Helena suggest that ${ }^{3} \mathrm{He} /{ }^{4} \mathrm{He}$ may be $\sim 6 \mathrm{R}_{\mathrm{A}}$ for HIMU. $\mathrm{Pb}-\mathrm{Sr}-\mathrm{Nd}$ and $\mathrm{He}$ isotope results for Shimada seamount (chapter 4) suggest that EM 2 also has ${ }^{3} \mathrm{He} /{ }^{4} \mathrm{He}$ less than MORB mantle, 4-5 $R_{A}$. Chapter 6 discusses the implications for convective mixing of isotopic components in the mantle and the temporal evolution of He and $\mathrm{Pb}$ isotopes in the Earth. 
CHAPTER 2

METHODS

$-27-$ 
Basalt glasses were used exclusively in the work on East Pacific seamounts and South Atlantic MORB because they represent most closely the quenched melt extruded onto the seafloor and therefore contain the major inventory of volatiles, and because the effects of seawater alteration can be minimized by selecting only the freshest samples. Samples from St. Helena analyzed for $\mathrm{Pb}$ isotopes were whole rock powders and for He isotopes were phenocrysts separated from the same samples.

\subsection{Sr and Nd Analyses}

All chemistry and solid source mass spectrometry were performed at Lamont-Doherty Geological Observatory. Samples from the small EPR seamounts were analyzed for $\mathrm{Sr}$ and $\mathrm{Nd}$ isotopes and $\mathrm{Sr}, \mathrm{Nd}$ and $\mathrm{Sm}$ concentrations following established methods (Zindler et al., 1984). Glass was handpicked to avoid alteration phases (and phenocrysts where possible), ultrasonically cleaned in methanol, then in ultrapure deionized water for $\sim 30$ minutes, and rinsed several times to remove any fine grained suspended material. Typically 25 to $50 \mathrm{mg}$ of unleached glass was dissolved for analysis. Samples were spiked with a multi-element spike (LaMES 1) containing enriched isotopes of ${ }^{40} \mathrm{~K}$, ${ }^{87} \mathrm{Rb},{ }^{137} \mathrm{Cs},{ }^{84} \mathrm{Sr},{ }^{149} \mathrm{Sm}$ and ${ }^{150} \mathrm{Nd}$. Sr and $\mathrm{Nd}$ i sotope ratios and concentrations and Sm concentrations were determined on the same aliquot. Spike was added to each sample in an amount to achieve optimally a measured ${ }^{150} \mathrm{Nd} /{ }^{146} \mathrm{Nd} \simeq 0.7$. Blanks determined for $\mathrm{Sr}$ and $\mathrm{Nd}$ were less than $2 \mathrm{ng}$ and $0.1 \mathrm{ng}$, respectively. 


\section{$2.2 \mathrm{~Pb}$ Analysis}

Several hundred milligrams of fresh glass, free of visible alteration, were handpicked under a binocular microscope. Whole rock powders were prepared from cut rock interiors to remove surface weathering. All traces of saw cuts were removed from the slabs by polishing with silicon carbide paper before jaw crushing. Powders were prepared from jaw crushed pieces using an agate mill.

After ultrasonic cleaning in methanol, then in deionized water, samples were leached in clean teflon beakers for 1 hour with ultrapure, cold $2.5 \mathrm{~N} \mathrm{HCl}$. After rinsing several times with ultrapure distilled water and drying, samples were dissolved in covered beakers using $\sim 5 \mathrm{ml}$ 8:1 HF: $\mathrm{HClO}_{4}$ at $150^{\circ} \mathrm{C}$. Separation of $\mathrm{Pb}$ was achieved using $\mathrm{AGl} \times 8$ 200-400 mesh anion-exchange resin following chemical procedures modified from Göpel et a1, (1985). B.lank levels were between 1-1.5 ng, negligible for the samples studied here. Samples were loaded onto modified, single Re loop-type filaments using the $\mathrm{Si}-g \mathrm{e} / / \mathrm{H}_{3} \mathrm{PO}_{4}$ technique. Samples were heated at $1000^{\circ} \mathrm{C}$ for $30 \mathrm{~min}$ in the mass spectrometer, and data was always collected between $1200-1300^{\circ} \mathrm{C}$ (see Tatsumoto, 1978). Typically, at least 3 blocks of 6 ratio determinations each were measured at three successively higher temperatures in the $1200-1300^{\circ} \mathrm{C}$ interval, and within-run precision was usually better than $.05 \% / a m u$. All data has been corrected using the sum of mean values of $6 / 4,7 / 4$ and $8 / 4$ fractionation from 13 analyses of NBS SRM 981 during this study (see Fig. 2.1). Mass discrimination was calculated assuming a linear fractionation law relative to accepted values for NBS 981 (Catanzaro et al., 1968), 
Figure 2.1 ${ }^{208} \mathrm{~Pb} /{ }^{204} \mathrm{~Pb}$ and ${ }^{207} \mathrm{~Pb} /{ }^{204} \mathrm{~Pb}$ against ${ }^{206} \mathrm{~Pb} /{ }^{204} \mathrm{~Pb}$

for analyses of NBS SRM 981 during the course of this work.

The mass discrimination line is $R=R_{m}(1+\varepsilon \delta m)$, where

$R=$ the real ratio, $R_{m}=$ the measured ratio, $\varepsilon=$ the

mass discrimination coefficient and $\delta m=$ the mass

difference (Hamelin et al., 1985b). The ${ }^{204} \mathrm{~Pb}$ error line

has a slope $=R_{2} / R_{1}$. The mass discrimination line

is constructed for $\varepsilon=1.37 \%$ /amu through the values for

absolute ratios in NBS 981 (given by Catanzaro et a1.,1968;

$6 / 4=16.937096,7 / 4=15.491344$ and $8 / 4=36.72134$, shown

by the open square). The ${ }^{204} \mathrm{~Pb}$ error line is shown

through the mean values measured here for NBS $981(6 / 4=$

$16.887 \pm .009,7 / 4=15.432 \pm .010$ and $8 / 4=36.523 \pm .027$;

uncertainties are $(\sigma)$. The open circles show values for

NBS 981 redetermined in the Paris lab using the

double-spike method $(6 / 4=16.918,7 / 4=15.465,8 / 4=$

36.622; Hamelin et al., 1985b). 


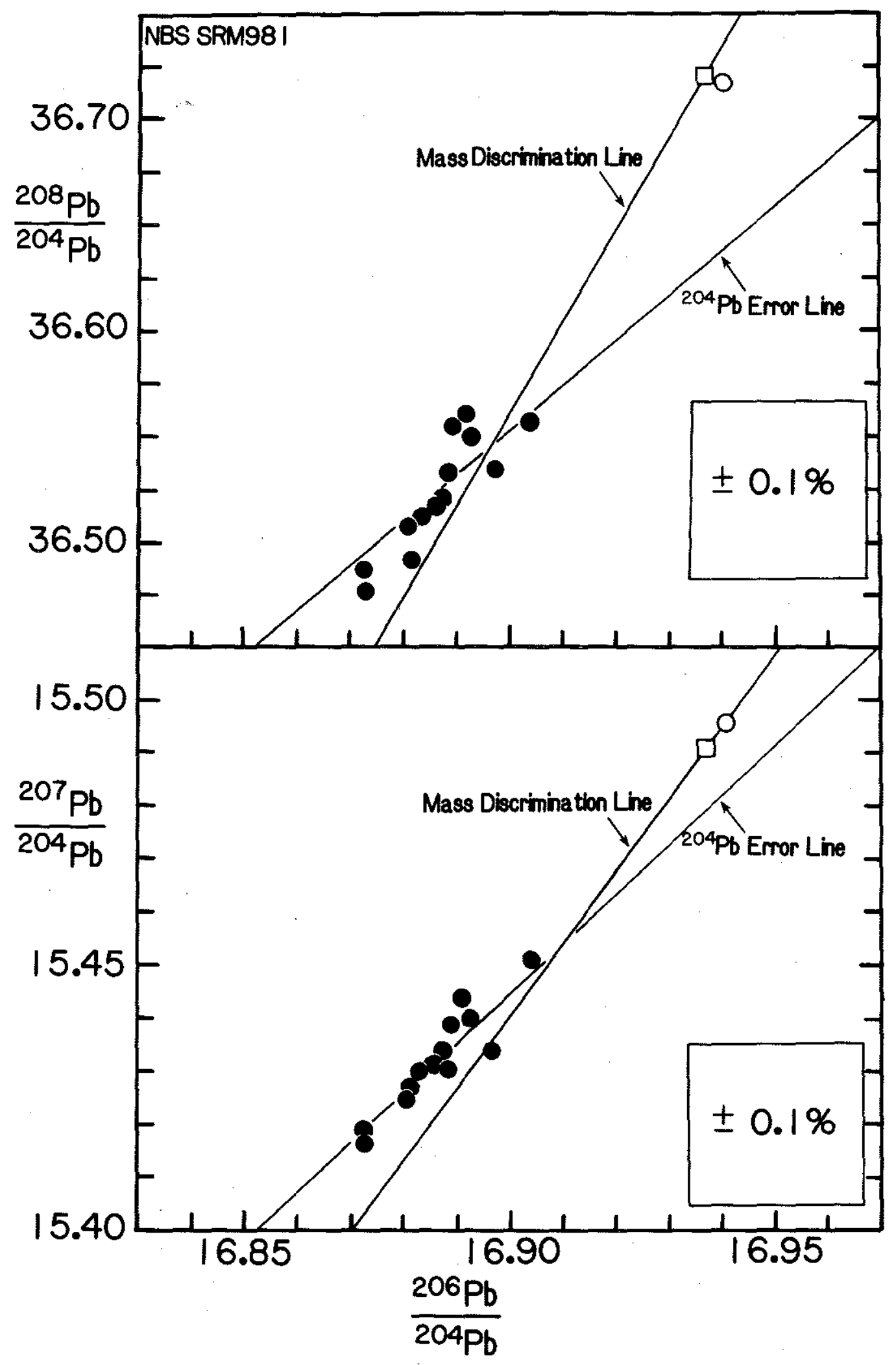


following methods outlined in Hamelin et a1. (1985b). The mean fractionation was $-1.37 \pm 0.23(1 \sigma) \% / \mathrm{amu}(\mathrm{n}=39)$ and all $\mathrm{Pb}$ data has been corrected using this mean value. Where replicate sample analyses were performed results were within the estimated uncertainty. Three glassy basalts from seamount 6 have also been analyzed for [Pb] by i.sotope dilution using a ${ }^{208} \mathrm{~Pb}$ spike and the procedures outlined above.

$\mathrm{Sr}, \mathrm{Nd}$ and $\mathrm{Pb}$ analyses were performed on a modified VG Micromass 30 mass spectrometer (12 inch radius) at Lamont-Doherty Geological Observatory. The signal measurement system consists of a Keithley 642 electrometer and a Hewlett-Packard 3456 A high-speed digital voltmeter. Room temperature and humidity is strictly controlled to provide good electronic stability.

\subsection{He Analysis}

Sample Preparation

Large glass chunks were crushed in a steel mortar, sieved and ultrasonically cleaned several times in $50 \%$ nitric acid, then in deionized water and then in ethanol. Only shards showing no sign of alteration were hand-picked under a binocular microscope, usually from the 2-4 $\mathrm{mm}$ size fraction, but in some cases a smaller size fraction had to be used to insure good glass quality. For tholeites, $\sim 50 \mathrm{mg}$ of sample was typically analyzed, while for alkali basalts, amounts ranged from 100 to $300 \mathrm{mg}$. Phenocrysts analyzed for He were separated from rock matrix by crushing rock chunks with a steel mortar and pestle, sieving to

a desirable size fraction, removing fine magnetic fractions by hand with a magnet, then using a Franz isodynamic magnetic separator. Phenocrysts 
were hand picked using a binocular microscope, ultrasonically cleaned in $50 \%$ nitric acid, water, acetone and methanol. The phenocrysts were then repicked under the microscope to assure good sample quality, selecting only grains of high optical purity. Sample descriptions are presented in the appendix.

All samples were analyzed at least once by crushing in vacuo. The crushing was performed using stainless steel sample tubes and solenoid-actuated pistons made of magnetic stainless steel. Some crushed powders retrieved from this analysis were sieved for the $<100 \mu \mathrm{m}$ fraction; these were then melted in a resistively heated furnace, using a tungsten heating element in a secondary vacuum, separated from the primary vacuum by a tantalum crucible. In some cases a split of uncrushed shards was melted to check the sample He budget. The experimental apparatus is also described in Kurz et al. (1987b).

Sample Purification and Mass Spectrometry

All sample processing is performed under computer automation. The sample processing line is shown schematically in Fig. 2.2. The line is constructed of $3 / 4$ inch O.D. stainless steel and is bakeable to $400^{\circ} \mathrm{C}$. All valves are pneumatically actuated stainless steel bellows valves. Much of the He isotope measurements, particularly the detection of He isotope disequilibrium (previousiy not observed in young basalts; chapter 3) have been realized due to the construction of this low blank sample processing vacuum line. The capability to analyze small samples represents a fundamental difference between this and previous data sets. 
Figure 2.2 Schematic diagram of the He isotope processing line. $L T C T=$ low temperature cryogenic trap; $H T C T=h i g h$ temperature cryogenic trap; RGA=residual gas analyzer (quadrupole mass spec); TP=turbomolecular pump; IP=ion pump; $R P=$ rotary pump. 


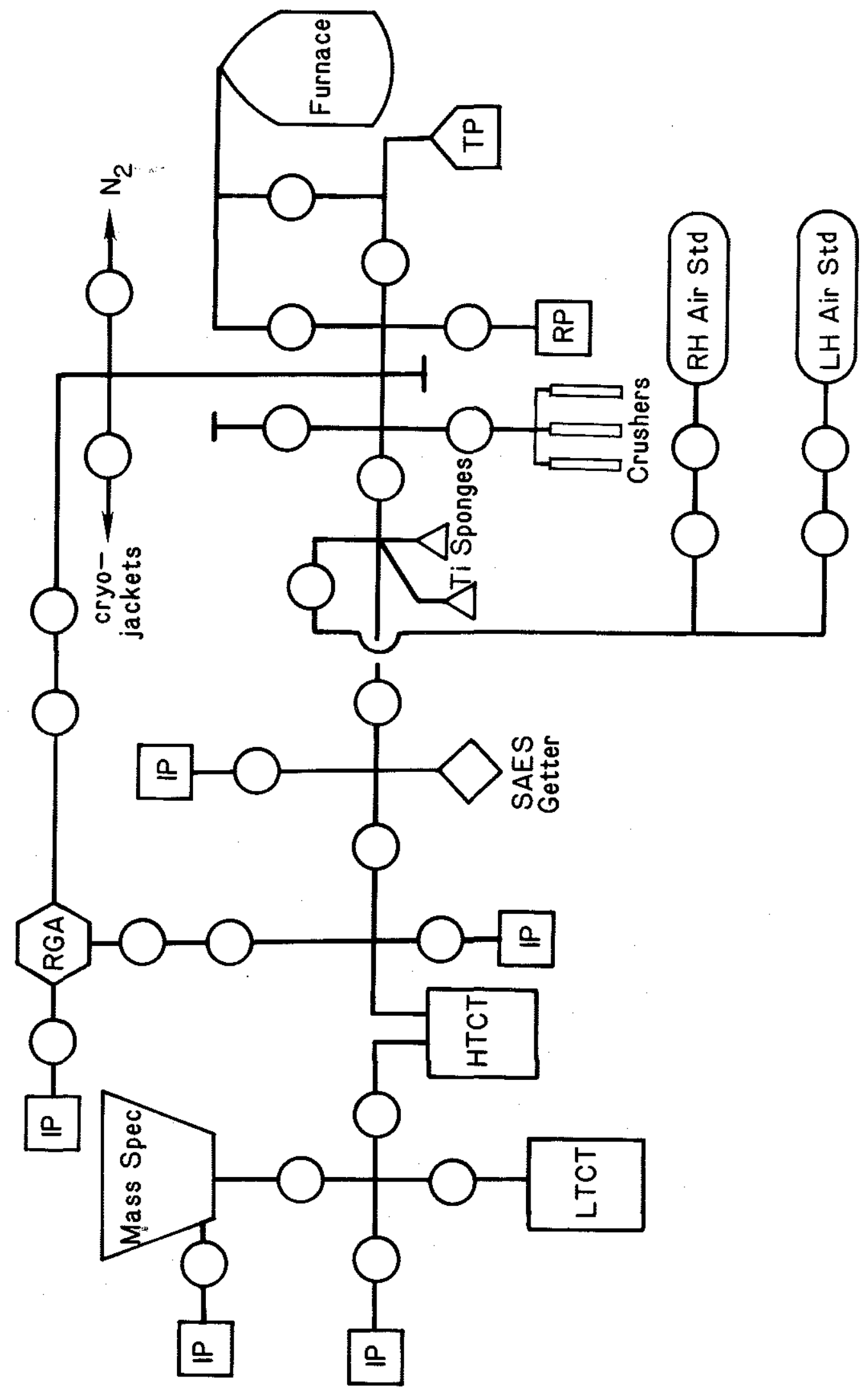


Extracted gases are purified sequentially; first by exposure to a hot $\left(800^{\circ} \mathrm{C}\right)$ titanium sponge which is then cooled to less than $200^{\circ} \mathrm{C}$, thereby removing reactive gases such as $\mathrm{CO}_{2}, \mathrm{CO}, \mathrm{O}_{2}$, and $\mathrm{N}_{2}$, and then to a SAES $\mathrm{Zr}-\mathrm{Al}$ getter cooled to room temperature to remove $\mathrm{H}_{2}$. A small split $(\sim 1 / 2000)$ of the sample is then inlet to a quadrupole mass spectrometer. The size of the measured ${ }^{4} \mathrm{He}$ peak is used to determine the subseqent split level of the sample (i.e. the fraction of the sample to be introduced to the mass spectrometer) prior to cryogenic pumping of the noble gases. The heavy noble gases ( $\mathrm{Ar}, \mathrm{Kr}$ and $\mathrm{Xe}$ ) were then adsorbed onto a stainless steel frit trap (high temperature cryo trap--HTCT) at $26^{\circ} \mathrm{K}$. He and $\mathrm{Ne}$ are then quantitatively $(>99.8 \%)$ adsorbed onto charcoal (low temperature cryo-trap--LTCT) at temperatures below $15^{\circ} \mathrm{K}$. He is cryogenically separated from $\mathrm{Ne}$ by selectively warming the LTCT to $38^{\circ} \mathrm{K}$, releasing the He into the mass spectrometer. The system is similar to that described by Lott and Jenkins (1984). Separation of He from $\mathrm{Ne}$ in this manner reduces uncertainties resulting from gas pressure effects on ion source characteristics in the mass spectrometer. Sample sizes introduced to the mass spectrometer ranged from $2 \times 10^{-10}$ to $2 \times 10^{-8} \operatorname{cCSTP}{ }^{4} \mathrm{He}$. Procedural blanks for both crushing and melting were typically $4 \pm 1 \times 10^{-11}$ cCSTP ${ }^{4} \mathrm{He}$.

The mass spectrometer is a $25.4 \mathrm{~cm}$ radius, branch tube design $\left(90^{\circ}\right.$ sector, all metal-type, modified after Nier, 1940), previously described by Jenkins (1974), Clarke et al. (1976) and Kurz (1982). It has an electron multiplier and faraday cup, used for simultaneous collection of ${ }^{3} \mathrm{He}$ and ${ }^{4} \mathrm{He}$, respectively, and is operated in static mode. Samples are introduced by expansion from the cryotrap through an activated Ti 
trap to remove hydrogen. Additionally, hydrogen within the mass spectrometer is reduced by two activated $\mathrm{Ti}$ traps in the static volume. The ion source is a modified Nier design with an electron beam focusing-electromagnet. Mass discrimination is calibrated by air standards. The accelerating voltage is controlled to within $0.025 \mathrm{~V}$ (out of $\sim 2845 \mathrm{~V}$ ) and the analyzer magnet current is stable to about $10 \mathrm{ppm}$. The mass spec is operated at a relatively low accelarating voltage to minimize memory effects. Precise timing of the analyses is controlled by the computer (PDP11/03). The system has never been used for extraterrestrial samples or for isotope dilution.

He is expanded into the mass spec for precisely 30 seconds. ${ }^{4} \mathrm{He}$ is measured on a faraday cup with a resolution of $1: 230$ while ${ }^{3} \mathrm{He}$ is simultaneously measured using a JLI model MM-2 electron multiplier with an adjustable acceptance slit. The slit is normally set for a resolution of 625 to resolve ${ }^{3} \mathrm{He}$ from $\mathrm{HD}-\mathrm{H}_{3}$. Interference between peaks at ${ }^{3} \mathrm{He}$ is undetectable at the $10^{-16}$ cCSTP ${ }^{3} \mathrm{He}$ level. The detection limit for samples is $5 \times 10^{-12}$ cCSTP ${ }^{4} \mathrm{He}$ and $\sim 3 \times 10^{-16}$ ccSTP ${ }^{3} \mathrm{He}$. The precision of the ${ }^{3} \mathrm{He} /{ }^{4} \mathrm{He}$ ratio is limited by ion-counting statistics. For samples of the order of $3 \times 10^{-9} \operatorname{cCSTP}{ }^{4} \mathrm{He}$ and ${ }^{3} \mathrm{He} /{ }^{4} \mathrm{He} 1.4 \times 10^{-6}$ (atmospheric ratio) the wihin-run precision is $\sim 4 \%$. The relative error for ${ }^{3} \mathrm{He}$ scales inversely with the square root of the ${ }^{3} \mathrm{He}$ sample size.

The response of the mass spectrometer is calibrated by introduction of air standards from an all-metal dual reservoir. A "standard rock" was also periodically analyzed (ALV 519 2-1-A) during the course of this work (Table 2.1). This sample is a small glassy lava bud approxixmately $3 \mathrm{~cm}$ 
Table 2.1

Analyses of ALV519 2-1-A

"Standard Rock"

\begin{tabular}{lcc}
\hline Date & $\begin{array}{c}{ }^{3} \mathrm{He} /{ }^{4} \mathrm{He} \\
\left(\mathrm{R} / \mathrm{R}_{\mathrm{A}}\right)\end{array}$ & $\sigma$ \\
\hline & & \\
$7 / 27 / 83$ & 8.18 & .10 \\
$8 / 8 / 83$ & 8.19 & .06 \\
$8 / 9 / 83$ & 8.22 & .06 \\
$8 / 13 / 83$ & 8.19 & .08 \\
$9 / 1 / 83$ & 8.30 & \\
$10 / 19 / 83$ & 8.19 & \\
$3 / 7 / 84$ & 8.02 & \\
$3 / 27 / 84$ & 8.16 & .06 \\
$6 / 19 / 85$ & 8.18 & .07 \\
$8 / 16 / 85$ & 8.17 & .05 \\
$10 / 25 / 85$ & 8.09 & .05 \\
$9 / 4 / 86$ & 8.13 & .04 \\
$11 / 29 / 86$ & 8.04 & \\
& $8.16 \pm 0.08(10)$ \\
mean & & \\
\hline A11 analyses by crushing in vacuo.
\end{tabular}


in diamater, part of FAMOUS sample ALV 519 2-1. The mean value for ${ }^{3} \mathrm{He} /{ }^{4} \mathrm{He}$ over the course of this work was $8.16 \pm 0.08(1 \sigma)$, or a precision of $\sim 1 \%$. The mean value is somewhat lower than the value obtained for another piece of the same rock sample (ALV 519 2-1-B) previously analyzed by Kurz (1982) as a "standard rock" ( ${ }^{3} \mathrm{He} /{ }^{4} \mathrm{He}=$ $7.94 \pm 0.12 R_{A}(1 \sigma)$. 
$-40-$ 


\section{CHAPTER 3}

HE ISOTOPE DISEQUILIBRIUM IN GLASSY

SUBMARINE BASALTS 


\section{1 Background}

The $(U+T h) / H e$ method is the oldest method of geochronology that involves radioactivity, but historically it has not been particularly successful. Even when problems of poor He retention and loss due to radiation damage are circumvented by analyzing suitable mineral phases (Keevil, 1943; Hurley, 1950; Fanale and Kulp, 1963), problems frequently remain with inherited He (Damon and Kulp, 1958; Noble and Naughton, 1968). In this chapter I use the isotope disequilibrium of ${ }^{3} \mathrm{He} /{ }^{4} \mathrm{He}$ between He trapped in vesicles and that dissolved in the glass phase of some young seamount basalts to determine $\left(U_{+} T h\right) / \mathrm{He}$ ages. The ${ }^{3} \mathrm{He} /{ }^{4} \mathrm{He}$ in vesicles (extracted by crushing in vacuo) allows a correction to be made in the dissolved phase He (by fusion of the remaining powder) for the inherited component in order to compute the radiogenic [He]. The method is applicable to rocks containing phases with different $\left(U_{+} T h\right) / H e$, and the results have implications for dating lavas in the age range of $10^{3}$ to $10^{6}$ years (potentially filling a gap between the limits of other directly applied geochronometers such as ${ }^{14} \mathrm{C}$ and $\mathrm{K}-\mathrm{Ar}$ ), and for reconstructing the geochemical history of young volcanic systems.

A suite of basaltic glasses from small seamounts near the East Pacific Rise has been analyzed. This seamount field erupts chemically diverse lavas ranging from tholeite (with MORB chemistry) to alkali basalt (from a source with time integrated higher $\mathrm{Rb} / \mathrm{Sr}, \mathrm{Nd} / \mathrm{Sm}$ and $\left(U_{+} T h\right) / H e$; (Batiza and Vanko, 1984; Zindler et al., 1984; Graham et al., 1984). Here I report data from seamount 6 , a small volcano (volume $=60$ 
$\mathrm{km}^{3}$; height $\left.=1300 \mathrm{~m}\right)$ located on $3 \mathrm{~m} \cdot \mathrm{y}$. old seafloor $\left(12^{\circ} 44^{\mathrm{t}} \mathrm{N}\right.$, $\left.102^{\circ} 35^{\prime} \mathrm{W}\right)$. Results for other seamount lavas are discussed in chapter

4. Seamount 6 consists of three coalesced volcanoes which have erupted a broad range of lava types. In all but one case, the alkali-rich lavas show $\mathrm{He}$ isotope disequilibrium between vesicles and glass (Table 3.1; Fig. 3.1). The glass phase shows a clear radiogenic signature, with ${ }^{3} \mathrm{He} /{ }^{4} \mathrm{He}$ much less than the atmospheric ratio $\left(R_{A}=1.384 \times 10^{-6}\right.$;

Clarke et al., 1976). Because the alkalic rocks are both enriched in $U$ and Th and have low He concentrations with respect to tholeites, radiogenic ingrowth of ${ }^{4} \mathrm{He}$ is clearly detectable on the short time scale involved, that is, $10^{3}$ to $10^{6} \mathrm{y}$. Transitional basalts, presumably derived by mixing of tholeitic and alkalic magmas (Batiza and Vanko, 1984; Zindler et al., 1984), sometimes show He isotope disequilibrium. Only one of 22 tholeites from this seamount field shows significant disequilibrium.

Following in vacuo crushing and analysis as outlined in chapter 2 , the $<100 \mu \mathrm{m}$ fraction was transferred to a clean Al-foil boat. The powders were then analyzed for the remaining helium by melting in vacuo in the resistively heated furnace. Furnace hot blanks were run before and after every sample. The average blank attributable to the Al boats is indetectable. The total processing blank for crushing and melting was the same, $\sim 4.3 \pm 0.3(1 \sigma) \times 10^{-11}$ cCSTP He. Results for three samples of different ages have been replicated, and one sample (6B2) was also analyzed by melting whole glass shards. Calculated ages for these cases are in agreement within analytical uncertainty (Table 3.1). 


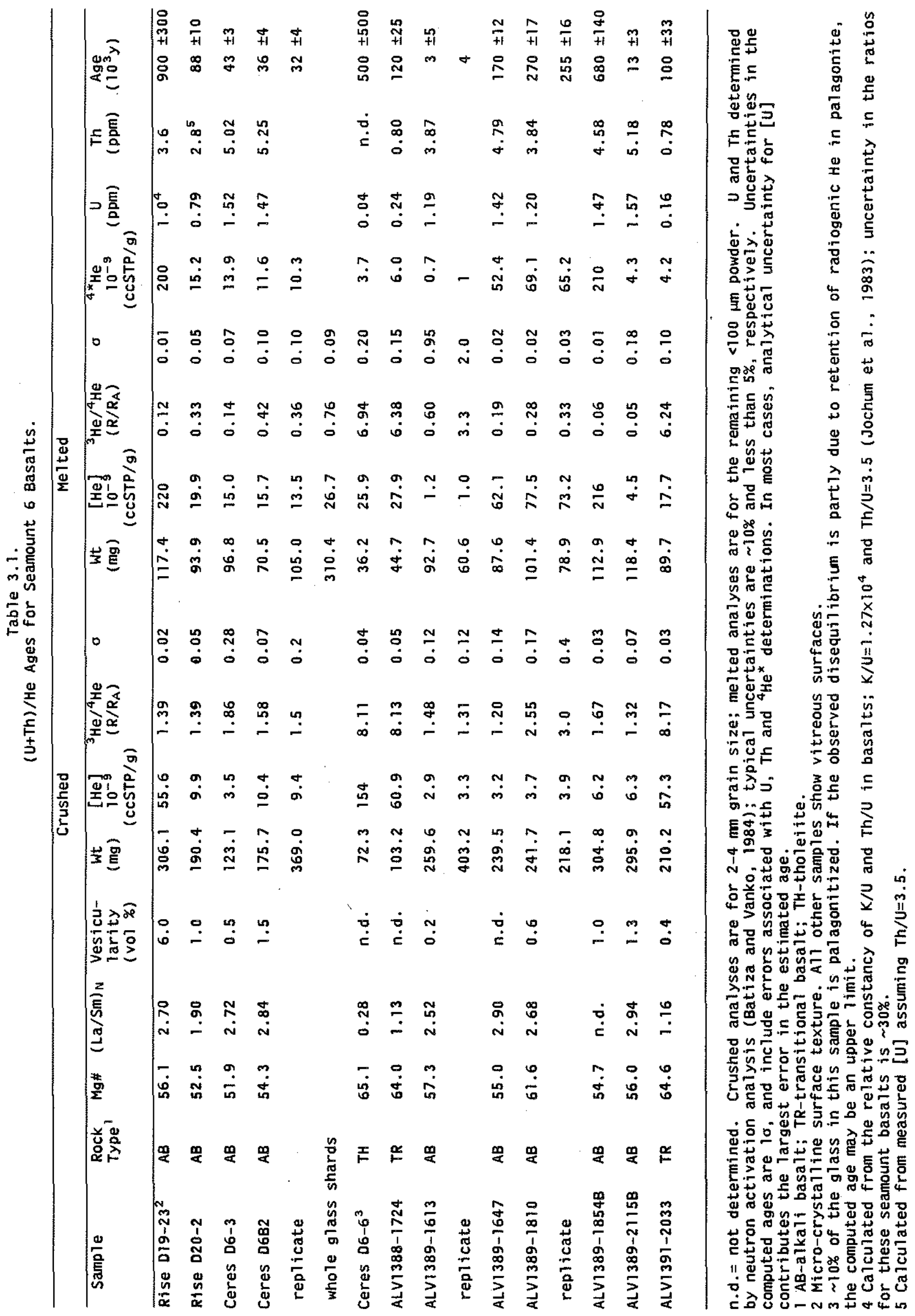


Figure 3.1 Histogram of ${ }^{3} \mathrm{He} /{ }^{4} \mathrm{He}$ in samples showing He isotope disequilibrium between vesicles and glass at seamount 6 . The range of ${ }^{3} \mathrm{He} /{ }^{4} \mathrm{He}$ in 22 other tholeites and transitional basalts from young seamounts near the East Pacific Rise is shown for comparison. 


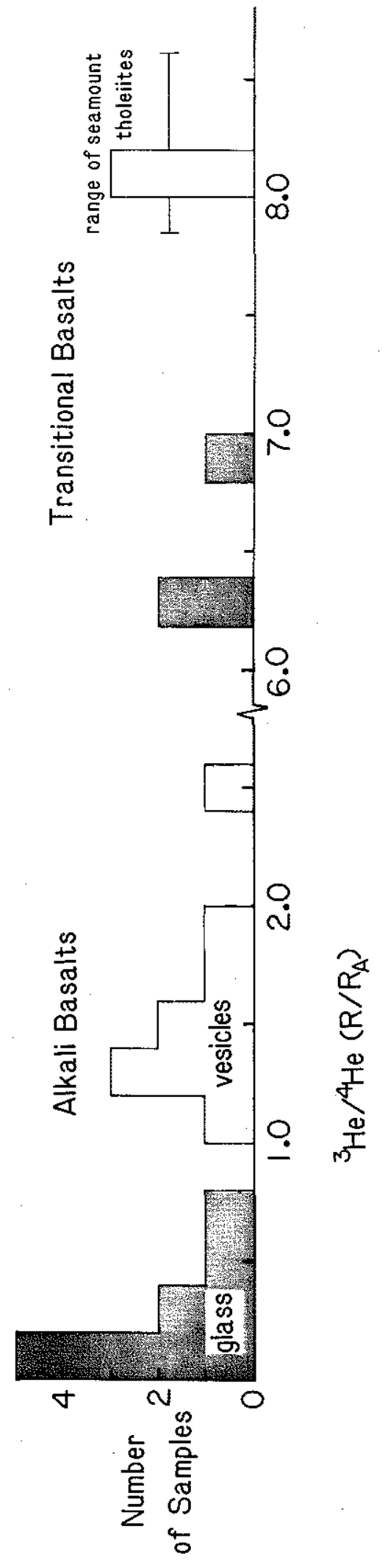

$-46-$ 


\section{$3.2(\underline{U}+\mathrm{Th}) /^{3} \mathrm{He}$ Dating}

The minimum detectable age is dependent upon the $U+T h$ content and the detection limit for He isotope disequilibrium. The amount of radiogenic He produced in a time $T$ (calculated from eq. 1.2, where for $T<10^{7} y$, $\left.e^{\lambda t}-1 \simeq \lambda t\right)$ is

$$
{ }^{4} \mathrm{He}^{*}=2.80 \times 10^{-8}[\mathrm{U}]\{(4.35+\mathrm{Th} / \mathrm{U})\} \mathrm{T} \quad(\mathrm{ccSTP} / \mathrm{g})
$$

where $T$ is in m.y., Th/U is the atom ratio, and [U] is the uranium concentration in ppm. I have used accepted decay constants (Steiger and Jager, 1977) and assumed secular equilibrium. The limiting factors in detecting ingrown ${ }^{4} \mathrm{He}$ are the reproducibility of the processing blank for analysis by mass spectrometry, and contamination from inherited He. For most of the present work the latter was the major limitation. The ${ }^{3}$ He detection limit $\left(\sim 2.8 \pm 0.3(1 \sigma) \times 10^{-16}\right.$ cCSTP, defined as twice the variability of the measured ${ }^{3} \mathrm{He}$ content of sample line processing blanks) may also become significant in distinguishing small age differences in very young samples. The minimum detectable age is 5000 years for the sample types analyzed here.

$(U+T h) / H e$ ages are calculated using several simplifying assumptions. The glass is assumed to be a closed system since the time of eruption, with no isotope re-equilibration between vesicles and glass. By definition ${ }^{4} \mathrm{He}^{*}=\left[{ }^{4} \mathrm{He}\right]_{g}-\left[{ }^{4} \mathrm{He}_{1}\right]_{g}$ and ${ }^{3} \mathrm{He}^{*}=\left({ }^{4} \mathrm{He}^{*}\right) \mathrm{R}_{r}$ $=\left[{ }^{3} \mathrm{He}\right]_{g}-\left[{ }^{3} \mathrm{He}_{1}\right]_{g}$, where $g$ and $v$ refer to glass and vesicle phases, $i$ and $r$ denote inherited and radiogenic components, respectively, and $\mathrm{R}=\left({ }^{3} \mathrm{He} /{ }^{4} \mathrm{He}\right)$. If vesicle ${ }^{3} \mathrm{He} /{ }^{4} \mathrm{He}$ reflects the inherited 
${ }^{3} \mathrm{He} /{ }^{4} \mathrm{He}$ ratio, $\left[{ }^{4} \mathrm{He}_{\mathrm{f}}\right]_{\mathrm{g}}=\left[{ }^{3} \mathrm{He},\right]_{g} / \mathrm{R}_{v}$, and

${ }^{4} \mathrm{He} *=\left[{ }^{4} \mathrm{He}\right]_{g}-\left\{\left(\left[{ }^{4} \mathrm{He}\right]_{g} \mathrm{R}_{g}-{ }^{4} H e^{*} \mathrm{R}_{r}\right) / \mathrm{R}_{v}\right\}$.

Rearranging gives the radiogenic $\mathrm{He}$ as

${ }^{4} H e^{*}=[H e]_{g}\left\{\left(R_{v}-R_{g}\right) /\left(R_{v}-R_{r}\right)\right\}$.

$R_{r}$, the radiogenic production ratio, depends upon sample composition and is between $10^{-8}$ and $10^{-7}$ for basalts (Morrison and Pine, 1955;

Mamyrin and Tolstikhin, 1984; Andrews, 1985). By far the most important reaction for in situ production of ${ }^{3} \mathrm{He}$ in seafloor basalts is ${ }^{6} \mathrm{Li}(\mathrm{n}, \alpha)^{3} \mathrm{H} \rightarrow{ }^{3} \mathrm{He}$, where the neutron production results from $\alpha$-bombardment of $\mathrm{Mg}, \mathrm{Si}$ and $\mathrm{O}$ target atoms. Since $\mathrm{R}_{\mathrm{r}} \ll<R_{v}$, approximating (3.2) as

$$
{ }^{4} H e^{*}=[H e]_{g}\left\{1-\left(R_{g} / R_{v}\right)\right\}
$$

does not introduce appreciable errors in the present case. Combining (3.1) and (3.3) gives

$$
T=3.58 \times 10^{7}[\mathrm{He}]_{g}\left\{1-\left(R_{g} / R_{v}\right)\right\} /[U](4.35+T h / U)
$$

Age relationships can be viewed in the conventional isochron diagram. Fig. 3.2 displays the relation for ${ }^{4} \mathrm{He} /{ }^{3} \mathrm{He}$ atom ratio against $(U+T h) /{ }^{3} \mathrm{He}$ for the range of interest here. Isochrons on this diagram are not necessarily straight as in the case for other radiogenic systems, due to radiogenic production of ${ }^{3} \mathrm{He}$ (which is of minor importance here). Fig. 3.2 shows isochrons for a radiogenic production ratio applicable to basalts $\left(10^{-8}\right)$, for samples ranging between $10^{4}-10^{6}$ years old. Seamount 6 alkali basalts are shown with respect to this diagram in Fig. 3.3. 


\begin{tabular}{|c|c|}
\hline gure 3.2 & $\begin{array}{l}{ }^{4} \mathrm{He} /{ }^{3} \mathrm{He}-(U+T h) /{ }^{3} \mathrm{He} \text { isochron diagram for ages } \\
\text { between } 10^{4} \mathrm{y} \text { and } 10^{6} \text { y and }(U+T h) /{ }^{3} \mathrm{He} \text { of interest. } \\
\text { Isochrons (in units of } 10^{3} \mathrm{y} \text { ) have been constructed for } \\
\text { initial }{ }^{3} \mathrm{He} /{ }^{4} \mathrm{He}=2.0 \mathrm{R}_{\mathrm{A}} \text {, similar to values measured } \\
\text { in the vesicles of alkali basalts at seamount } 6 \text {. Note that } \\
\text { isochrons are not straight on this diagram due to a } \\
\text { radiogenic }{ }^{3} \mathrm{He} /{ }^{4} \mathrm{He} \text { production ratio of } 10^{-8} \text {, } \\
\text { characteristic of basalts. }\end{array}$ \\
\hline
\end{tabular}




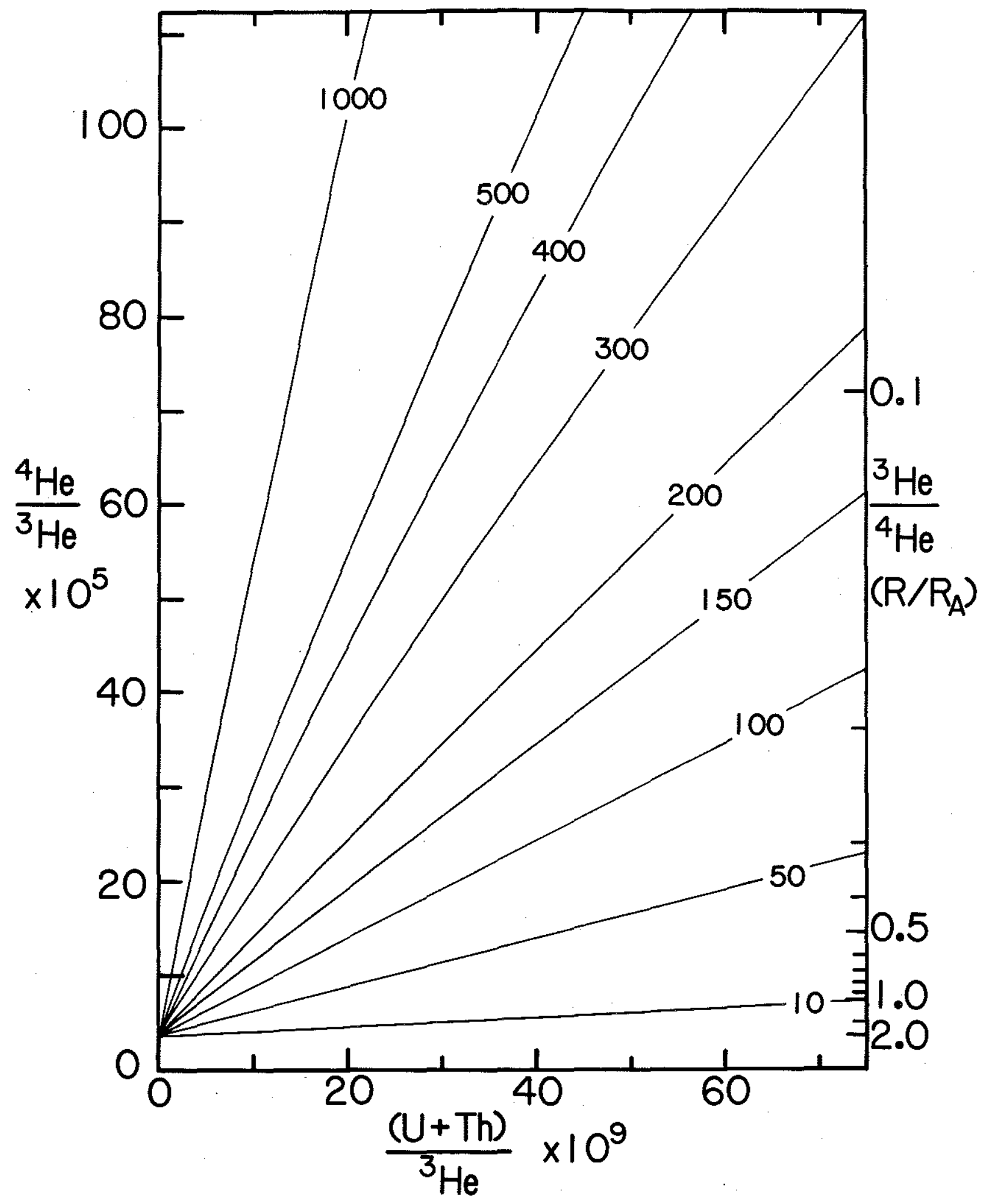


Figure 3.3 Seamount 6 alkali basalts on the ${ }^{4} \mathrm{He} /{ }^{3} \mathrm{He}-\left(U_{+} \mathrm{Th}\right) /{ }^{3} \mathrm{He}$ isochron diagram. 


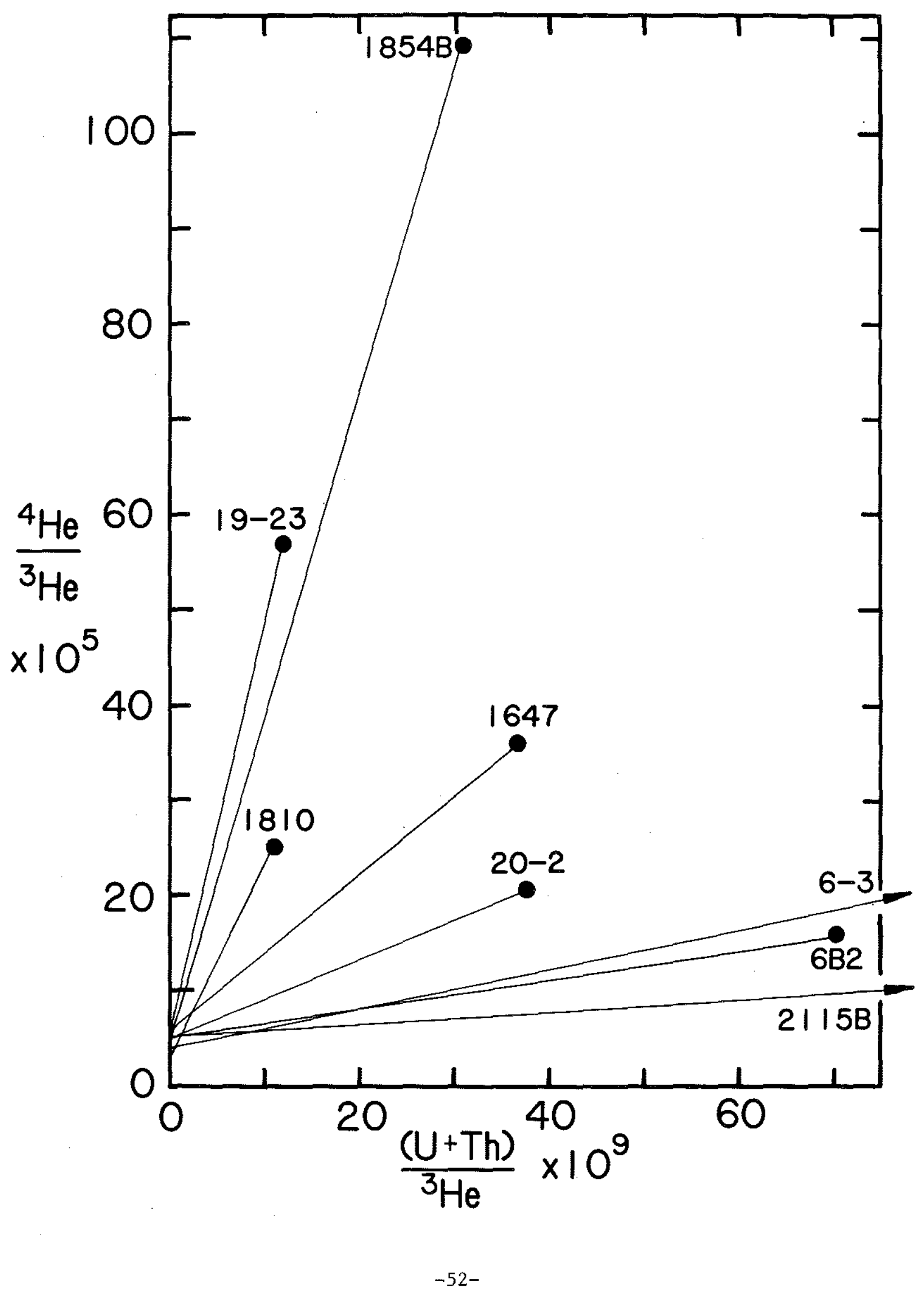




\subsection{Potential Problems}

Some processes considered in the following discussion which could potentially affect inferred eruption ages include 1) atmospheric contamination; 2) incomplete separation of radiogenic and inherited components; 3) alteration of $U$ and Th concentrations; 4) implantation of $\alpha$-particles from relatively $U$, Th-rich alteration surfaces and 5) He loss from the glass.

Vesicularities of the samples were estimated visually and range between 0.2 and 6 volume percent (Table 3.1), with vesicle diameters between $\sim 0.1-0.5 \mathrm{~mm}$. The ratio of ${ }^{3} \mathrm{He}$ trapped in vesicles to that dissolved in the glass is similar to the value determined for MORB at comparable vesicularities (Fig. 3.4), where He isotope disequilibrium has not been observed (Kurz and Jenkins, 1981). The fact that partitioning of inherited He $\left({ }^{3} \mathrm{He}\right)$ is similar for these different rock types suggests that no isotope fractionation occurred between gas and melt during eruption. Atmospheric contamination of the dissolved phase He is insignificant, as the ${ }^{3} \mathrm{He} /{ }^{4} \mathrm{He}$ ratio is much less than $1 \mathrm{R}_{\mathrm{a}}$ and close to the theoretical production ratio for basalts. In addition, the dissolved [He] in a basalt at equilibrium with air-saturated seawater is $2 \times 10^{-9} \mathrm{ccSTP} / \mathrm{g}$ (for Henry's Law constant $\mathrm{K}=3.7 \times 10^{-4} \mathrm{ccSTP} / \mathrm{g}-\mathrm{atm}$; Kurz, 1982; Jambon et a1., 1985; Marty and Ozima, 1986), whereas measured concentrations in the alkali basalts range up to $2 \times 10^{-7} \mathrm{cCSTP} / \mathrm{g}$. At the present time it is difficult to demonstrate unequivocally that the vesicles of these alkali basalts do not contain a fraction of an atmospheric (or seawater) He component, but such contamination requires 
Figure $3.4 \quad{ }^{3} \mathrm{He}_{\text {vestales }} /{ }^{3} \mathrm{Heglass}$ VS. vesicularity (volume $\%$ )

for seamount 6 transitional and alkali basalts. MORB partitioning curve from Kurz (1982). 


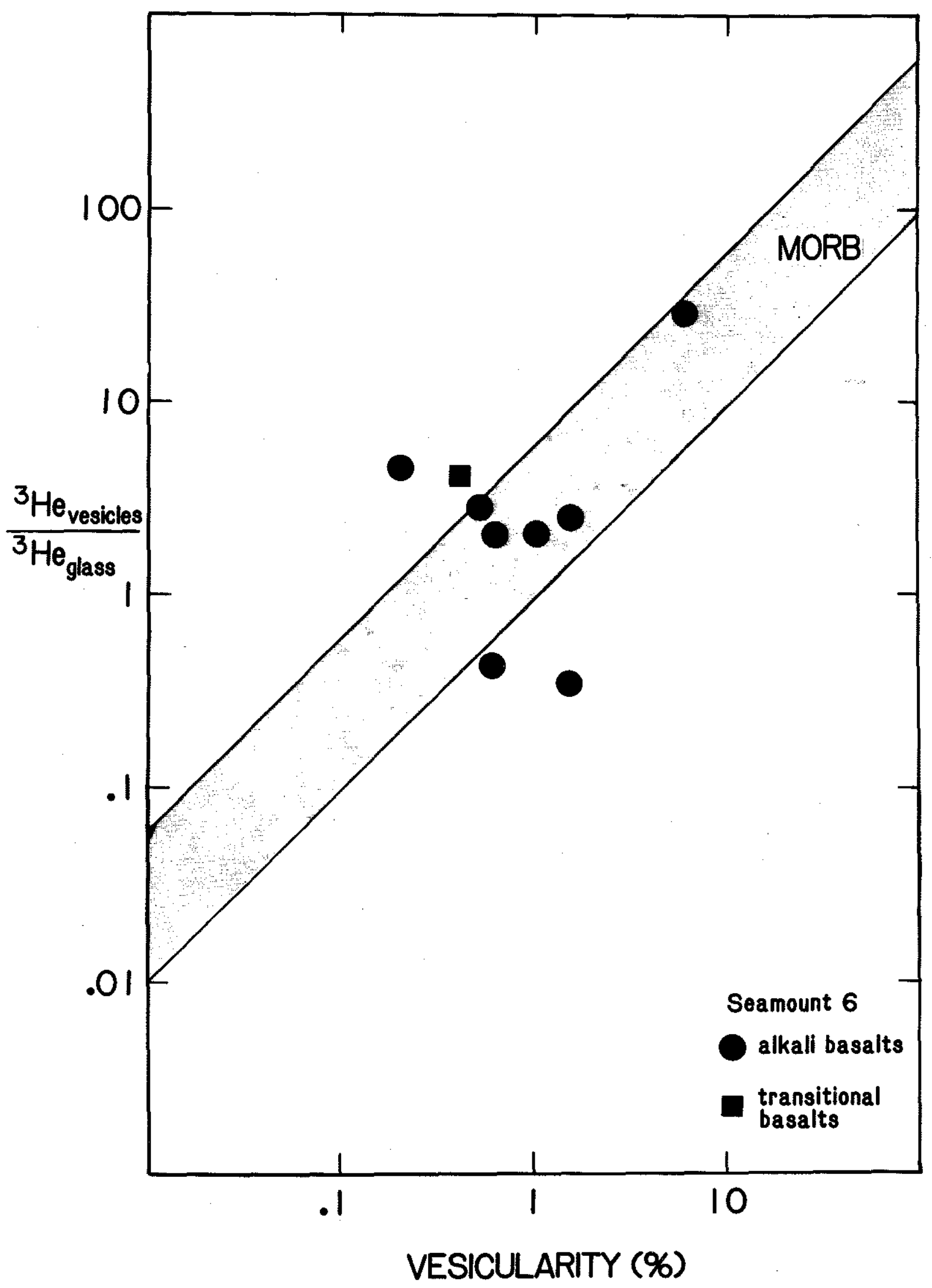


He migration along cracks because volume diffusion is too slow. I found no evidence for the presence of significant cracks in either vesicle walls or the surrounding glass using the scanning electron microscope.

The age computations using He isotope disequilibrium assume that crushing and melting afford effective separation of inherited and radiogenic components. The subatmospheric ${ }^{3} \mathrm{He} /{ }^{4} \mathrm{He}$ in the glass demonstrates clearly that the dissolved He is predominantly of radiogenic origin, but transfer of radiogenic He from newly exposed surfaces during crushing might lower the isotopic ratio of the inherited He. Such an effect should be related to surface area and relative He concentrations in vesicies and glass. To address this problem, I crushed two samples in a stepwise manner (CD 6B2 and ALV 1389-1810; Table 3.2). Systematically lower ${ }^{3} \mathrm{He} /{ }^{4} \mathrm{He}$ was not measured in sequentially crushed aliquots of these two samples, demonstrating that the ${ }^{3} \mathrm{He} /{ }^{4} \mathrm{He}$ measured by more extensive crushing of other samples predominantly reflects the trapped (inherited) component.

$U$ and Th addition to glass could have varying effects on measured ages depending upon the degree of retention of the generated $\alpha$-particles. Surficial $U$ and Th may implant $\alpha$-particles, but this process al so causes some radiation damage, and most of the added He will likely be lost due to enhanced diffusion. Palagonite and manganese crusts are the most important $U$ and Th-rich alteration phases (Macdougall et al., 1979; Newman et al., 1983). Significant contribution from alteration phases has been avoided by careful cleaning and microscopic selection of very fresh samples that show vitreous surfaces on all sides. 
Table 3.2

Stepwise Crushing Results for Seamount 6 Alkali Basalts

\begin{tabular}{|c|c|c|c|c|}
\hline Sample & $\begin{array}{l}\text { Weight } \\
\text { (mg) }\end{array}$ & $\begin{array}{l}\text { He released } \\
\left(10^{-10} \text { ccSTP }\right)\end{array}$ & $\begin{array}{l}{ }^{3} \mathrm{He} /{ }^{4} \mathrm{He} \\
\left(\mathrm{R} / \mathrm{R}_{\mathrm{A}}\right)\end{array}$ & $\sigma$ \\
\hline \multirow[t]{2}{*}{$\mathrm{CD} \quad 6 \mathrm{~B} 2$} & 369.0 & $\begin{array}{l}8.32 \\
2.54 \\
9.56 \\
5.36 \\
4.62 \\
4.12\end{array}$ & $\begin{array}{l}1.33 \\
1.66 \\
1.27 \\
1.43 \\
2.07 \\
1.84\end{array}$ & $\begin{array}{l}.20 \\
.31 \\
.10 \\
.25 \\
.16 \\
.57\end{array}$ \\
\hline & \multicolumn{4}{|c|}{$\begin{array}{l}\text { total }[\mathrm{He}]=9.4 \times 10^{-9} \mathrm{ccSTP} / \mathrm{g} \\
{ }^{3} \mathrm{He} /{ }^{4} \mathrm{He}=1.5 \pm 0.3(1 \sigma) \mathrm{R}_{\mathrm{A}}\end{array}$} \\
\hline \multirow[t]{2}{*}{$\begin{array}{r}A L V 1389 \\
-1810\end{array}$} & 218.1 & $\begin{array}{l}4.17 \\
1.42 \\
3.00\end{array}$ & $\begin{array}{l}2.40 \\
2.51 \\
4.10\end{array}$ & $\begin{array}{l}.21 \\
.61 \\
.53\end{array}$ \\
\hline & \multicolumn{4}{|c|}{$\begin{array}{l}\text { total }[\mathrm{He}]=3.9 \times 10^{-9} \mathrm{ccSTP} / \mathrm{g} \\
{ }^{3} \mathrm{He} /{ }^{4} \mathrm{He}=3.0 \pm 0.4(1 \sigma) \mathrm{R}_{\mathrm{A}}\end{array}$} \\
\hline
\end{tabular}


Some possible mechanisms of He loss include migration along high diffusivity paths, $\alpha$-ejection, and volume diffusion of He, which might lead to loss from vesicles or glass, or to their partial isotopic reequilibration. He loss to high diffusivity paths is related to the population of micro-cracks, which ultimately depends upon the thermo-mechanical response of the glass to cooling and other changes. Significant $(>10 \%)$ loss requires crack spacing to be of order 10 times the diffusive distance for a given sample age, and of appropriate geometry that He loss is effective. For a diffusion coefficient $\left(D_{\mathrm{He}}\right) \simeq 10^{-17} \mathrm{~cm}^{2} / \mathrm{sec}$ at seafloor temperatures (Kurz and Jenkins, 1981) and ages of $10^{4}$ to $10^{5} \mathrm{y}$, crack scale lengths of $10-100 \mu \mathrm{m}$ are required. There is no evidence for such cracks with the SEM. Ultimately, weathering and devitrification are likely to be more important violations of glass remaining a closed system in $(U+T h) / H e$ dating, but careful sample selection avoids these problems.

The average $\alpha$-stopping distance for an alkali basalt glass is 25 $\mu m$. (A sample calculation for the ${ }^{238} \mathrm{U}$ decay chain for $6 \mathrm{~B} 2$ is given in Table 3.3). From geometric considerations only $25 \%$ of the ${ }^{4} \mathrm{He}$ generated within a surface layer of this thickness can be ejected from the sample (Bender, 1970). Such loss produces less than $1 \%$ uncertainty in the computed age for a sample from the outer $2 \mathrm{~mm}$ (the typical size of glass chips analyzed here) of a basalt pillow. Seamount 6 samples are from pillow rims typically $0.5-1.0 \mathrm{~cm}$ thick. The diffusion coefficient for He in basaltic glass is presently a point of debate (Kurz and Jenkins, 1981; Jambon et al., 1985), but upper limits for the extent of diffusive loss $\left(D_{\mathrm{He}} \simeq 10^{-15} \mathrm{~cm}^{2} / \mathrm{sec}\right.$ at seafloor temperatures and 


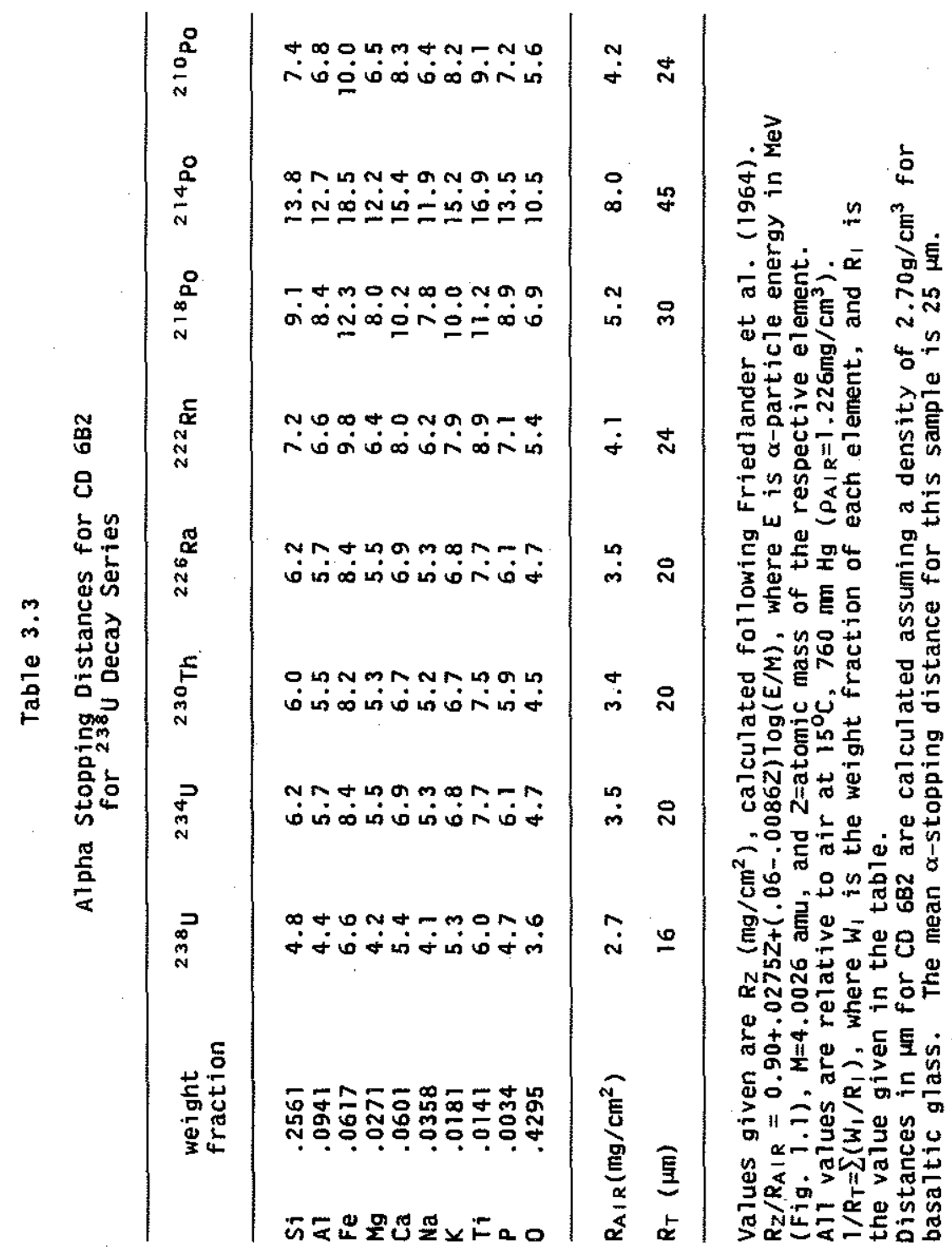


$0.5 \mathrm{~cm}$ pillow rim thickness) are $4 \%$ and $11 \%$ in $10^{4} \mathrm{y}$ and $10^{5} \mathrm{y}$, respectively. These losses, although significant, are comparable to the uncertainties.

The extent of re-equilibration between glass and vesicles was estaimated using a simple diffusion model that assumes homogeneous distribution of spherical vesicles with uniform radius. Results of this model are shown in Fig. 3.5 along with the apparent age reduction that would occur for seamount 6 samples. The true age is increasingly underestimated as vesicularity increases and as vesicle size decreases. A typical deviation from the true age $\left(10^{5} \mathrm{y}, 1 \%\right.$ vesicularity and 300 $\mu \mathrm{m}$ vesicle radius) is about $1 \%$. Such a calculation is simplistic, (e.g., it neglects the size distribution of vesicles) but it demonstrates the relative magnitude of the reequilibration effect. Partial re-equilibration between vesicles and glass also leads to lower vesicie ${ }^{3} \mathrm{He} /{ }^{4} \mathrm{He}$. Although this may be a significant effect $(\sim 10 \%)$ on our estimate of the inherited ${ }^{3} \mathrm{He} /{ }^{4} \mathrm{He}$ for older samples, it has much less effect on the calculated age because the inherited component of the glass phase He is a smaller fraction of the measured [He]. In addition, if more than one vesicle size population is present, the larger vesicles (which are less affected by such re-equilibration) will dominate the measured ${ }^{3} \mathrm{He} /{ }^{4} \mathrm{He}$ because of larger He contents. Micro-vesicles may contribute to the $\mathrm{He}$ content determined by melting previously crushed powders, but unless they have ${ }^{3} \mathrm{He} /{ }^{4} \mathrm{He}$ much different from the He released by crushing, the calculated ages will be similar. This is because the amount of. ${ }^{4} \mathrm{He}$ * calculated in eq. 3.2 remains unaffected (i.e., $\left[{ }^{4} \mathrm{He}\right]$ increases but $\mathrm{R}_{\mathrm{g}}$ increases correspondingly). The 
Figure 3.5 Model for partial vesicle-glass equilibration by diffusion. The deviation (lowering) of the age $T$ (in $\%$ ) as a function of the true age is shown for vesicularities of $1 \%$ and $10 \%$ and a range of vesicle diameters from $100-300 \mu \mathrm{m}$. The diffusion coefficient of $\mathrm{He}$ in basalt glass is $\simeq 10^{-17}$ $\mathrm{cm}^{2} / \mathrm{sec}$. Vesicle geometry in this model is assumed to be the simplest case of homogeneously distributed spheres of uniform size. For low vesicularities $(<10 \%)$ an individual vesicle domain is defined by a surrounding glass volume, $V=$ $p(4 \pi / 3) r^{3} / v e s$, where ves is the volume fraction of vesicles and $p$ is a geometric factor accounting for the vesicle packing fraction. A concentric shell in diffusive communication with a vesicle has a thickness approximated by $\sqrt{D T}$, and volume $V_{D}=(4 \pi / 3)\left\{(r+\sqrt{D T})^{3}-r^{3}\right\}$. The fractional lowering ( $f$ ) of the apparent age from the true age will be the fraction of ${ }^{4} \mathrm{He}^{*}$ missing from the glass which is lost to vesicles. For glass cubes with uniform $U$ and Th distribution $(p=8 /(4 \pi / 3)), f=V_{D} / V$ $=\operatorname{ves}(\pi / 6)\left\{(r+\sqrt{D T})^{3} / r^{3}-1\right\}$. Circles are alkali basalts and the square is a transitional basalt from seamount 6. The diffusive effects are not appreciable in this model except in the case of the oldest sample. 


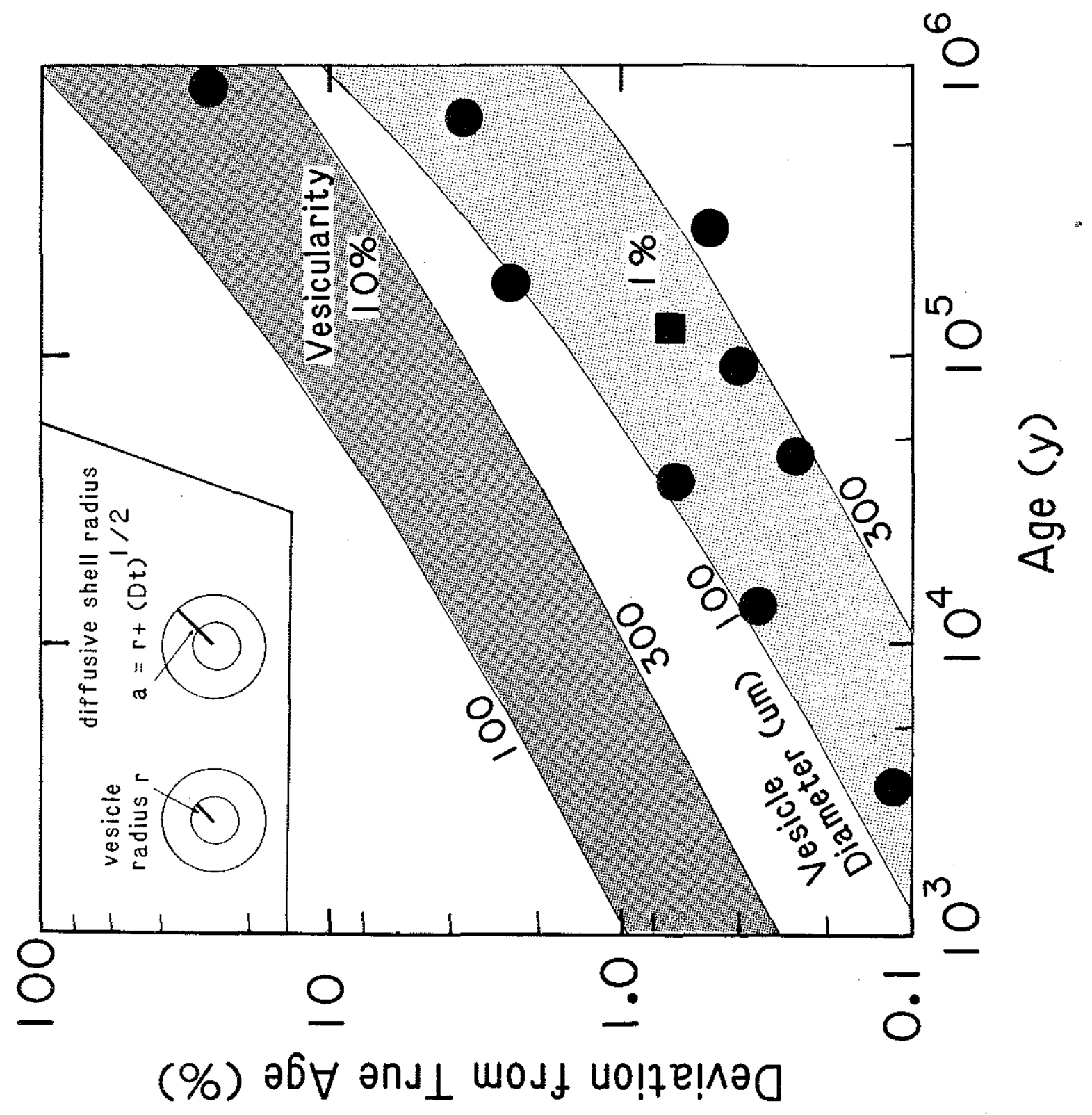


assumption of insignificant transfer of radiogenic He from the glass phase to the vesicle phase is more important. This assumption appears to be justified in the present case, given the relatively uniform ${ }^{3} \mathrm{He} /{ }^{4} \mathrm{He}$ measured by crushing over a wide range of He contents dissolved in the glass, and the stepwise crushing results (Table 3.2). Although there are some inherent complications in the $(U+T h) / H e$ technique, the uncertainties introduced are comparable to, or less than, the analytical error for the studied samples.

\subsection{Volcanic Evolution at Seamount 6}

At seamount 6 , a pair of transitional basalts from the eastern satellite cone (ALV 1388 and 1391) have similar ages, 100,000 y; (Fig. 3.6); another pair of samples, the two Ceres 6 alkali basalts, dredged from a terrace between this eastern cone and the main vent, also have similar ages, $\sim 40,000 \mathrm{y}$. Collectively, the alkali basalts show a smooth trend in Mg number vs. age, with a minimum between 50,000 to 100,000 y ago (Fig. 3.7). The approximate agreement between the age of the eastern cone and the age of the Mg \# minimum suggests that a change in magmatic "plumbing" occurred near this time. The event is marked by subsequent supply of less differentiated magma to the central volcanic complex. It may also be evident as a temporal trend in inherited He $\left({ }^{3} \mathrm{He}\right)$ content of the erupted lavas. Total ${ }^{3} \mathrm{He}$ content, and the partitioning of inherited He between vesicles and melt is shown in Fig. 3.8. More recent lavas appear to have been "mined" of their magmatic He and show lower inherited He contents: 
Figure 3.6 SEABEAM map of seamount 6 (from Smith, 1987) showing distribution of $\left(U_{+} T h\right) /$ He ages. 


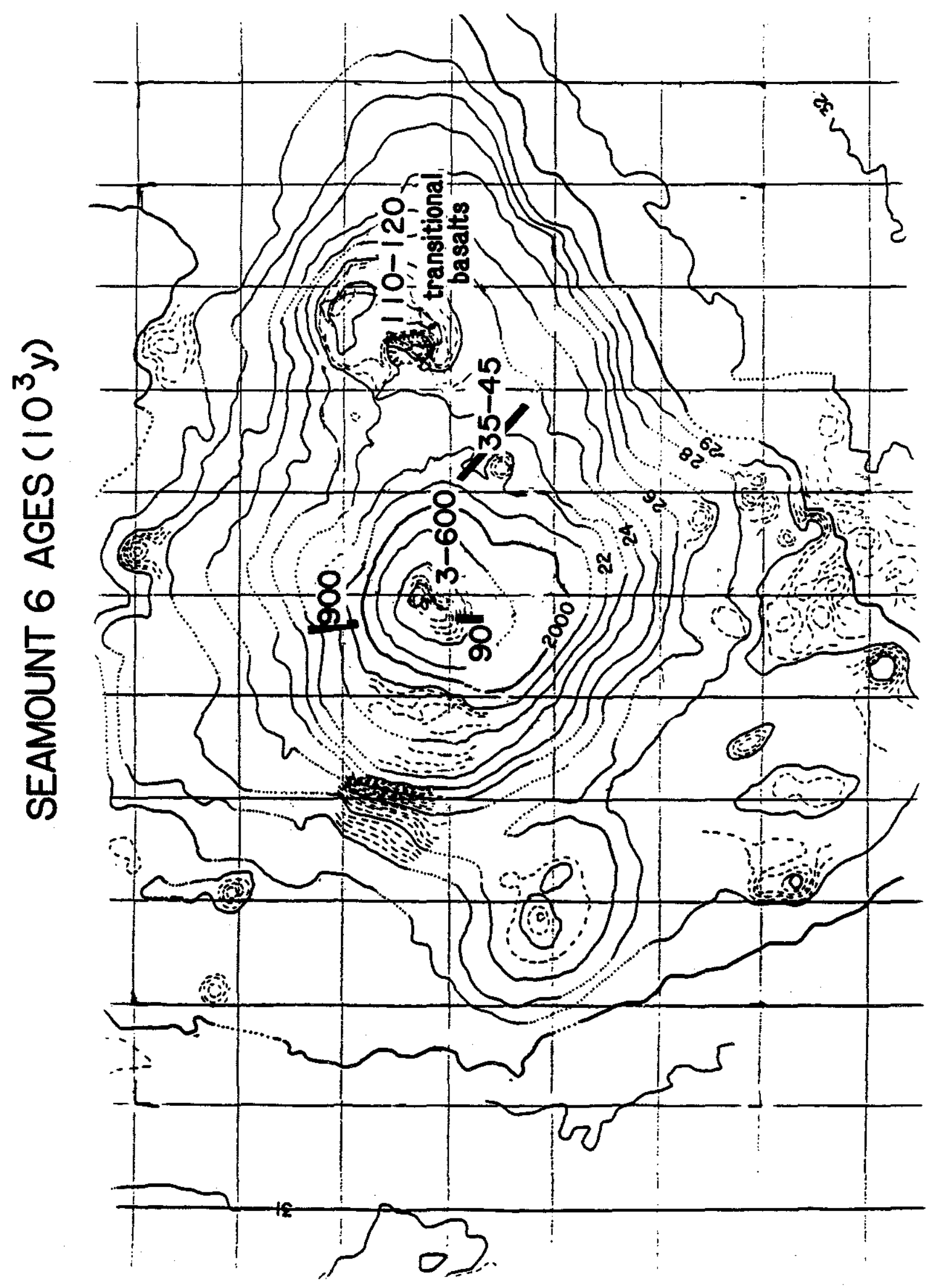


Figure $3.7 \mathrm{Mg \#}\left(=100 \times \mathrm{Mg} /\left[\mathrm{Mg}+\mathrm{Fe}^{2+}\right]\right)$ vs. Age for the youngest seamount 6 alkali basalts. Age uncertainties are $\pm 2 \sigma$; uncertainties in Mg\# are similar to the size of sample points. 


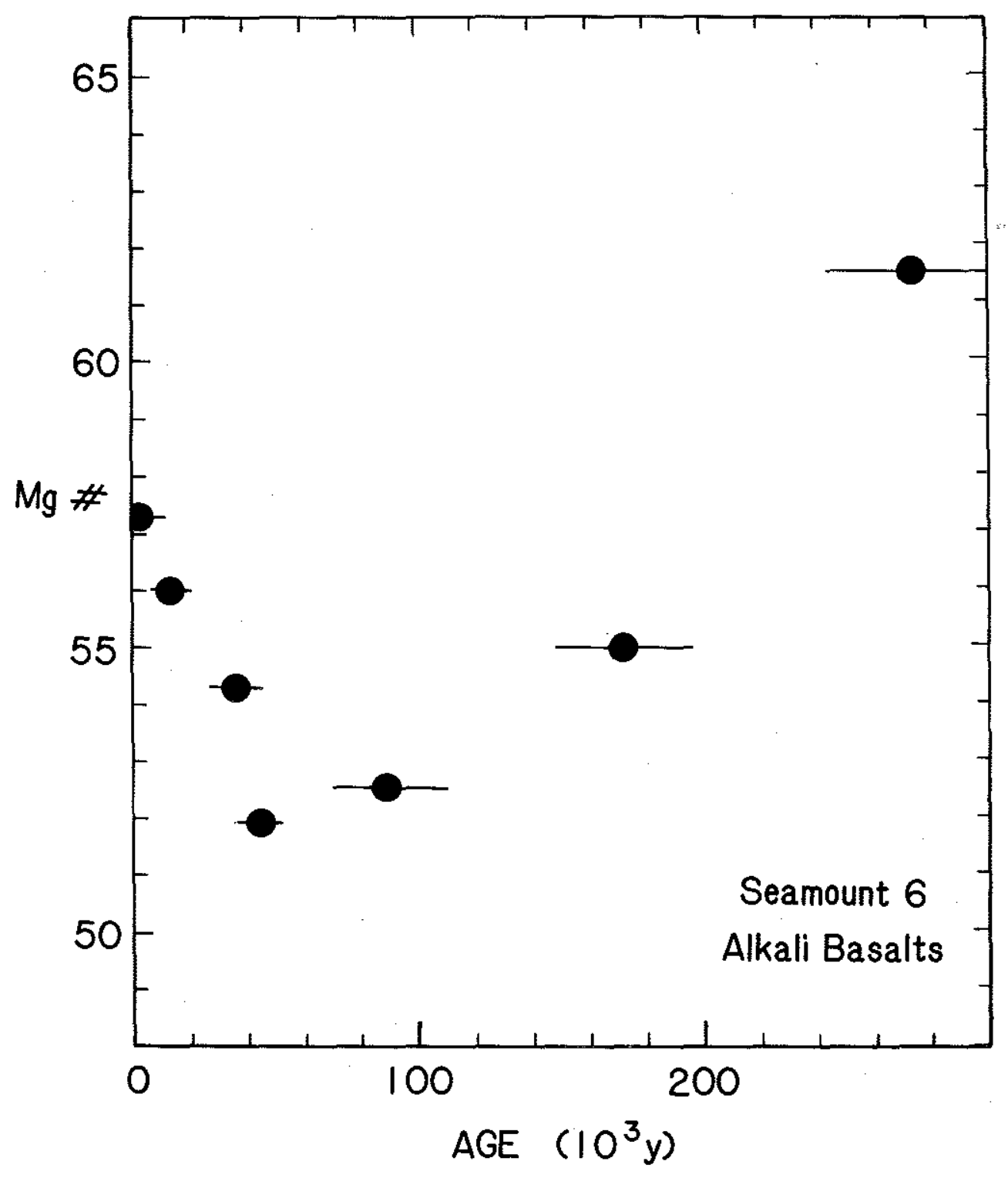


Figure 3.8 A. $\left({ }^{3} \mathrm{He}\right)_{\text {ves }} /\left({ }^{3} \mathrm{He}\right)_{\text {total }}$ and
B. Total $\left[{ }^{3} \mathrm{He}\right]$ for seamount 6 alkali basalts
against age of eruption. $2 \sigma$ uncertainties are indicated. 


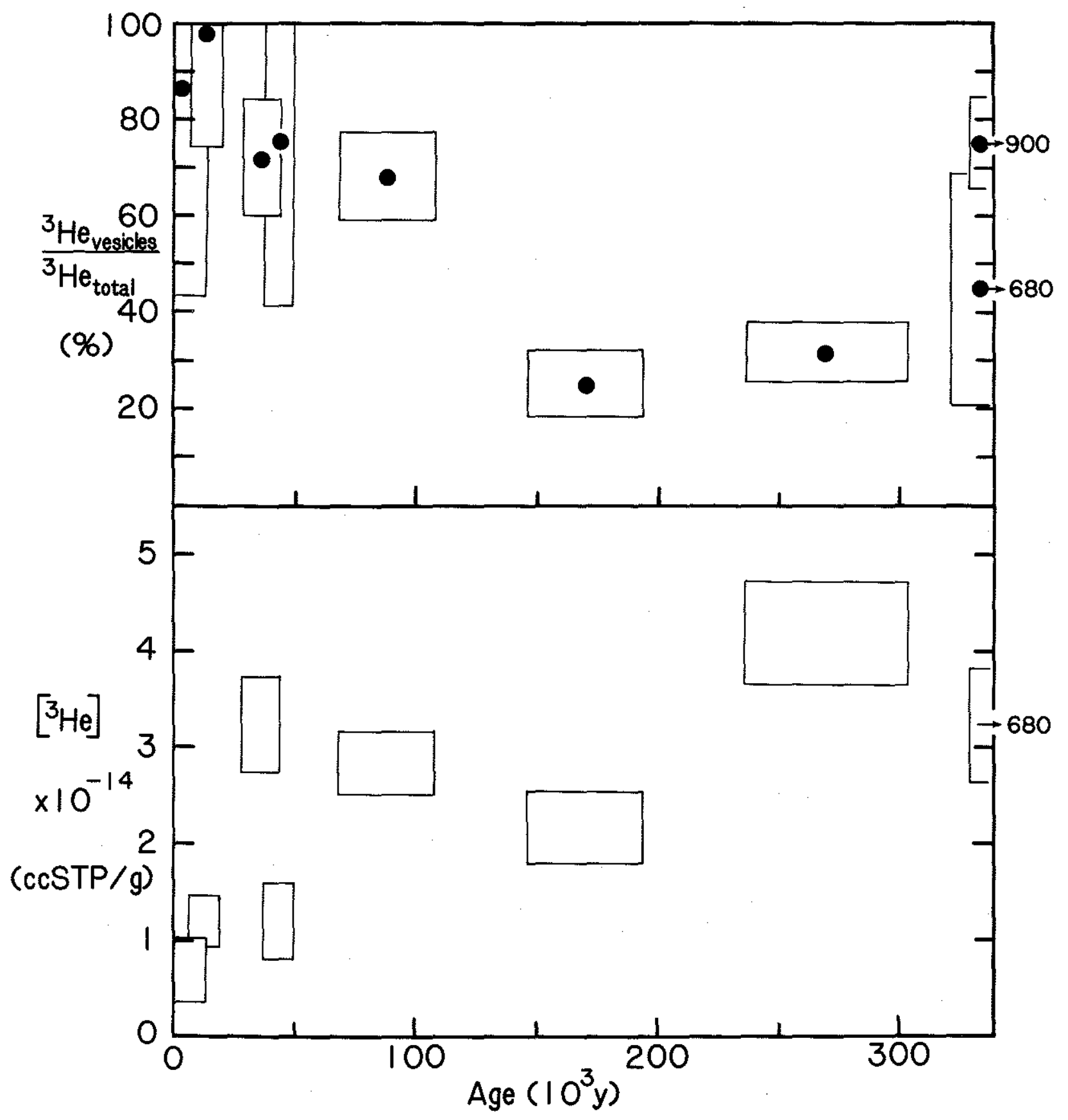


Although the spatial distribution of ages for the summit lavas (RISE and ALV1389 samples) is complex, they do not appear to violate principles of stratigraphic superposition. Additionally, the uniform ages obtained for the two distinct areas away from the main summit are evidence that the ages are geologically meaningful, representing times of eruption, and thus provide a means to study volcanic evolution. The youth of the exposed lavas at seamount 6 has been confirmed by ALVIN dive observations (e.g., the lack of significant sediment cover) and is also consistent with magnetic gradiometer measurements (McNutt, 1986). Honda et al. (1987) have determined a ${ }^{40} \mathrm{Ar} /{ }^{39} \mathrm{Ar}$ model age $<2 \mathrm{~m} . \mathrm{y}$. for RISE D19-23, consistent with the He isotope disequilibrium age of $\sim 8 \times 10^{5}$ y. All evidence points to volcanism occurring at seamount 6 at a significant distance off-axis of the East Pacific Rise. These results demonstrate that $(U+T h) / H e$ dating holds considerable promise for studying young volcanic systems and for directly dating seafloor rocks on flow lines away from spreading centers. A preliminary analysis of olivine and pyroxene phenocrysts in some older ocean island basalts (age 10 m.y.) from St. Helena and Tubuai i (chapter 5) shows that He isotope disequilibrium is clearly detectable (for the Tubuai sample), and that the inherited ${ }^{3} \mathrm{He} /{ }^{4} \mathrm{He}$ may be recovered in cases of relatively high inherited He contents (inferred to be much of the He released by crushing). Before the results can be reliably used for age determinations, considerable effort will be needed to delineate how effective the separtion of $U_{+} T h$ from He has been for both the inclusions and dissolved components contained within the lattice of phenocrysts. 


\section{CHAPTER 4}

HELIUM, LEAD, STRONTIUM AND NEODYMIUM ISOTOPE

CONSTRAINTS ON MAGMA GENESIS AND MANTLE HETEROGENEITY

BENEATH YOUNG PACIFIC SEAMOUNTS 


\subsection{Introduction}

In this chapter I discuss the results for $\mathrm{He}, \mathrm{Pb}, \mathrm{Sr}$ and $\mathrm{Nd}$ isotopes in glassy tholeitic, transitional and alkali basalts erupted at young seamounts in the eastern Pacific. The isotope systematics have implications for the nature of mantle heterogeneity, and for magma genesis beneath young oceanic lithosphere during the transition of submarine volcanoes from a ridge flank to a mid-plate environment.

\subsubsection{EPR Seamounts}

Two suites of near axis seamounts have been studied. The first is a set of small seamounts located on young $(<7 \mathrm{m.y.})$, relatively thin lithosphere east of the East Pacific Rise, between $9-14^{\circ} \mathrm{N}$ on the Cocos Plate (Fig. 4.1; Table 4.1). The second is Larson's seamounts (seamounts $B, C$ and $E$ ) near $21^{\circ} \mathrm{N}$. The $21^{\circ} \mathrm{N}$ seamounts are composed of tholeitic basalts, while the $9-14^{\circ} \mathrm{N}$ seamounts have erupted more diverse lavas ranging from tholeites to alkali basalts (Batiza and Vanko, 1984). Representative major element analyses are given in Table 4.2. Lavas erupted at these near-axis seamounts typically have higher Mg\# $\left(=\mathrm{Mg} /\left(\mathrm{Mg}+\mathrm{Fe}^{2+}\right)\right)$ than lavas from nearby ridge segments (Batiza and Vanko, 1984). Evolved lavas (e.g., tholeiltes at seamount B, and hawaites at seamount 6) are sometimes associated with caldera collapse (Batiza et a1., 1984; Smith, 1987), evidence that magma evolution may occur within volcanic plumbing systems which are distinct from those feeding the nearby ridge axis.

For the present work alkali basalts are distinguished by 1) plotting above the Macdonald and Katsura (1964) line on a total alkalies- $\mathrm{SiO}_{2}$ 
Table 4.1

Seamounts Studied

\begin{tabular}{|c|c|c|c|c|c|c|}
\hline Seamount & $\begin{array}{l}\text { Lat } \\
{ }^{0} \mathrm{~N}\end{array}$ & $\begin{array}{l}\text { Long } \\
{ }^{\circ} \mathrm{W}\end{array}$ & $\begin{array}{l}\text { Height } \\
\text { (km) }\end{array}$ & $\begin{array}{l}\text { Vol ume } \\
\left(\mathrm{km}^{3}\right)\end{array}$ & $\begin{array}{l}\text { Lithosphere } \\
\text { Age (m.y.) }\end{array}$ & $\begin{array}{l}\text { Rock Type } \\
\text { Recovered }\end{array}$ \\
\hline B & $20^{\circ} 48^{\prime}$ & $109^{\circ} 17^{\prime}$ & 0.7 & $\sim 7$ & 0.4 & $\mathrm{TH}$ \\
\hline C & $20^{\circ} 50^{\prime}$ & $109^{\circ} 12^{\prime}$ & 0.7 & $\sim 7$ & 0.4 & TH \\
\hline$E$ & $20^{\circ} 48^{\prime}$ & $109^{\circ} 23^{\prime}$ & 0.7 & $\sim 7$ & 0.6 & TH, TR \\
\hline $\mathrm{N}-2$ & $12^{\circ} 02^{\prime}$ & $101^{\circ} 34^{\prime}$ & 1.28 & 35 & 4.5 & $\mathrm{TH}, \mathrm{TR}$ \\
\hline$N-3$ & $11^{\circ} 27^{\prime}$ & $101^{\circ} 35^{\prime}$ & 0.50 & 13 & 4.2 & $\mathrm{TH}, \mathrm{AB}$ \\
\hline$N-5$ & $12^{\circ} 15^{\prime}$ & $100^{\circ} 30^{\prime}$ & 1.10 & 19 & 7 & $A B$ \\
\hline$N-7$ & $11^{\circ} 13^{\prime}$ & $101^{\circ} 08^{\prime}$ & & & 5 & $T H, T R$ \\
\hline 1 & $8^{\circ} 48^{\prime}$ & $103^{\circ} 54^{\prime}$ & 1.3 & 47 & 0.6 & $\mathrm{TH}$ \\
\hline 6 & $12^{\circ} 45^{\prime}$ & $102^{\circ} 30^{\prime}$ & 1.28 & 59 & 3.0 & $T H, T R, A B$ \\
\hline 7 & $13^{\circ} 22^{\prime}$ & $102^{\circ} 33^{\prime}$ & 2.30 & 590 & 3.5 & TH, TR \\
\hline \multicolumn{7}{|c|}{ Mathematicians Ridge } \\
\hline $\begin{array}{l}\text { intra-trans- } \\
\text { form smt }\end{array}$ & $16^{\circ} 06^{\prime}$ & $111^{\circ} 33^{\prime}$ & $\sim 2$ & $\sim 600$ & 6.5 & $A B$ \\
\hline $\begin{array}{l}\text { elongate } \\
\text { smt }\end{array}$ & $18^{\circ} 10^{\prime}$ & $113^{\circ} 52^{\prime}$ & & & 3.5 & $A B$ \\
\hline $\begin{array}{l}\text { Clarion Isl. } \\
\text { flank }\end{array}$ & $18^{\circ} 21^{\prime}$ & $114^{\circ} 43^{\prime}$ & & & & $A B$ \\
\hline Shimada & $16^{\circ} 52^{\prime}$ & $117^{\circ} 28^{\prime}$ & 3.90 & 1500 & $18-21$ & Icelandite \\
\hline
\end{tabular}




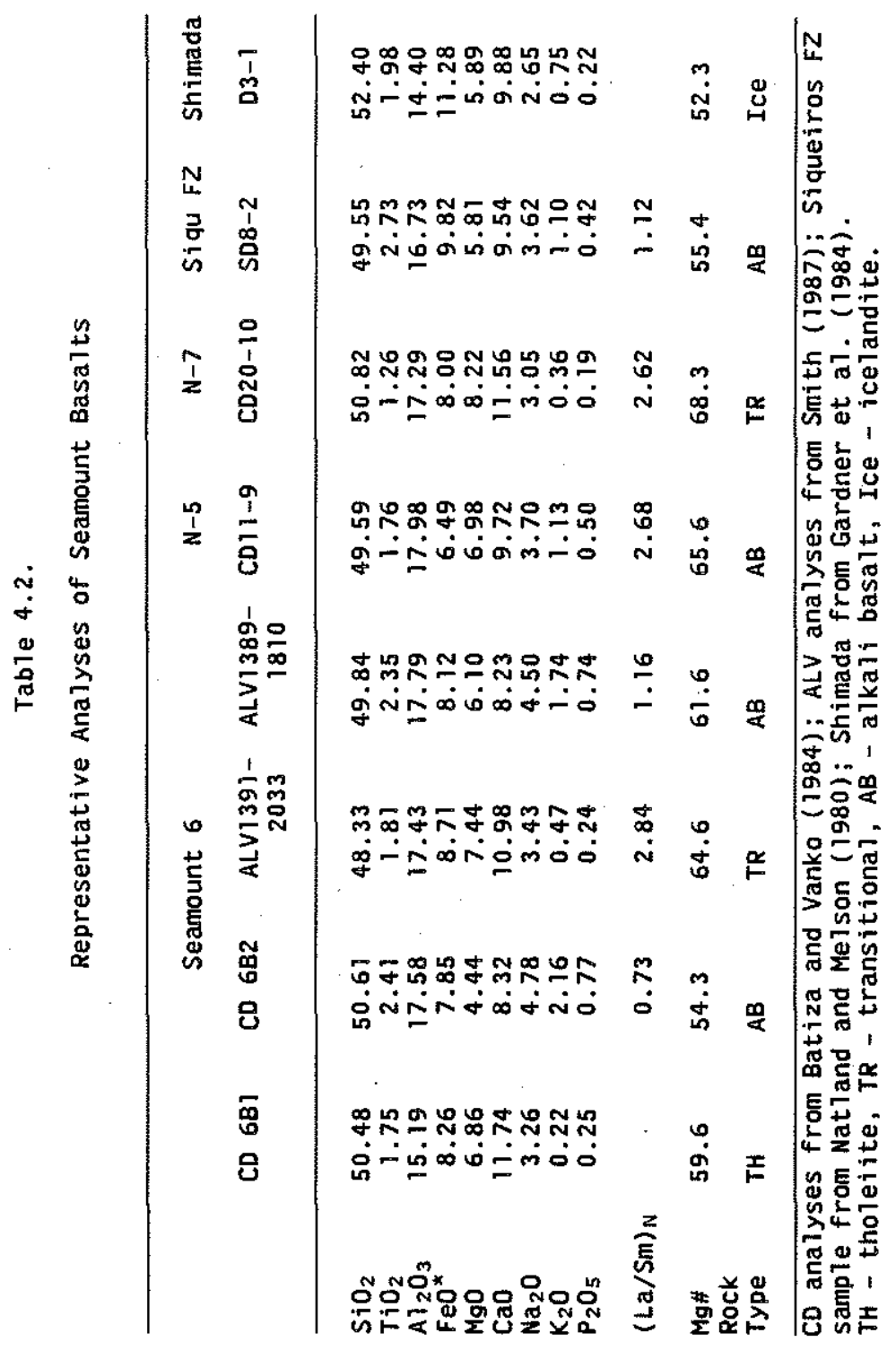




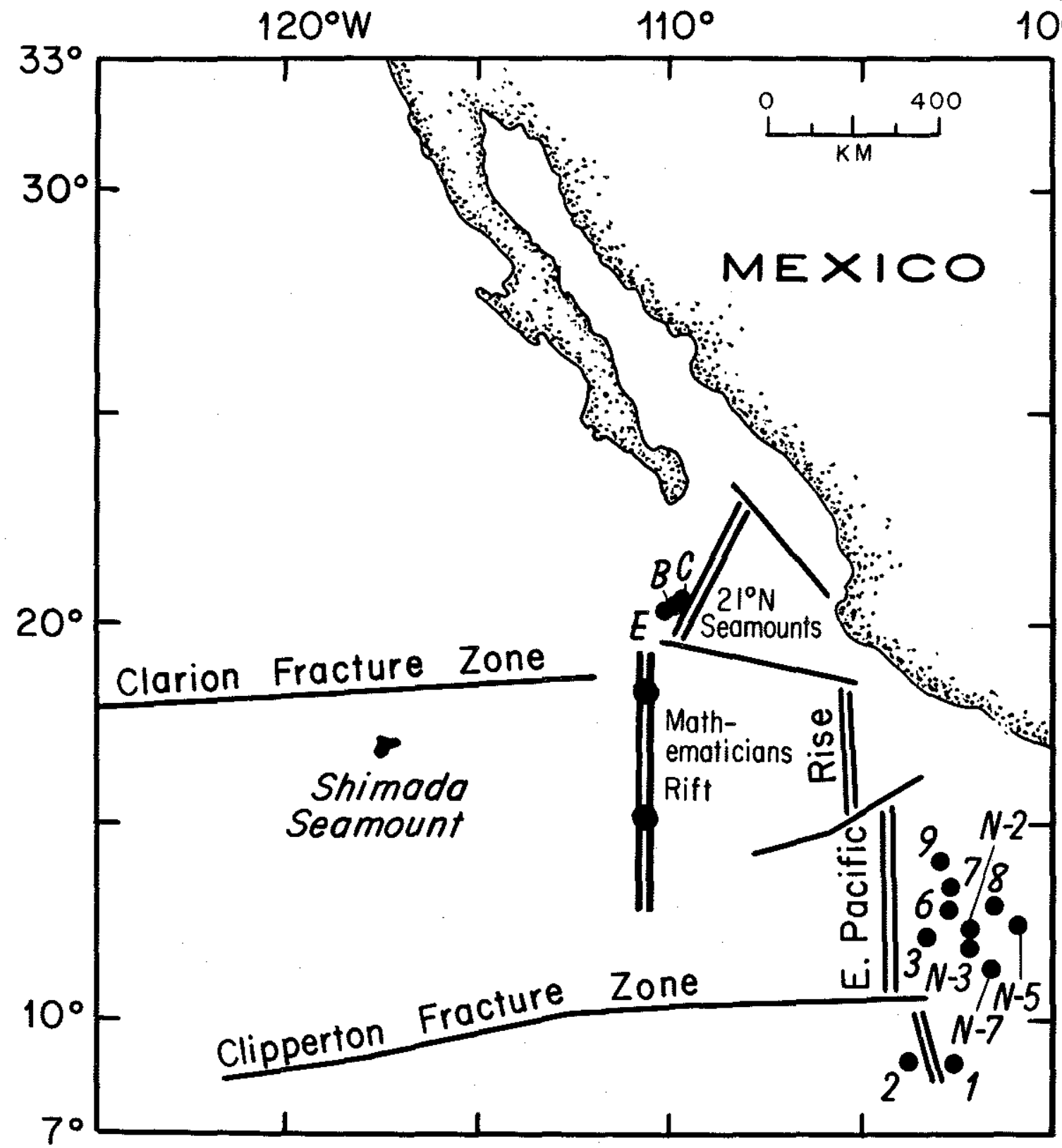

Figure 4.1 Map of East Pacific seamounts studied. 
diagram (which distinguishes Hawai ian alkali basalts from tholeiites;

Fig. 4.2) and 2) having $(\mathrm{La} / \mathrm{Sm})_{N}$ greater than 2. Tholeites fall on or below the line and have (La/Sm) less than 1. Remaining samples are considered transitional in alkali content and $(\mathrm{La} / \mathrm{Sm})_{\mathrm{N}}$. Isotope compositions are very systematic for the rock types defined in this way; i.e., seamount tholeites (and most transitional basalts) show distinctly less radiogenic $\mathrm{He}, \mathrm{Pb}$ and $\mathrm{Sr}$ isotopic compositions than alkali basalts. The only exception is ${ }^{3} \mathrm{He} /{ }^{4} \mathrm{He}$ in lavas from seamount 7 ; by the criteria above they are tholeiites, but in terms of ${ }^{3} \mathrm{He} /{ }^{4} \mathrm{He}$ they appear more characteristic of transitional basalts. The transitional basalts appear to be produced by mixing of tholeitic and alkalic end-members derived from chemically distinct source regions. Alkali basalts at these seamounts are not systematically lower in $\mathrm{SiO}_{2}$ than the tholeites or transitional basalts. Thus, their alkalic affinity does not result from $\mathrm{SiO}_{2}$ depletion (a characteristic of melting peridotite at high pressure), but rather from high $\mathrm{Na}_{2} \mathrm{O}+\mathrm{K}_{2} \mathrm{O}$ abundances, which might result from low degrees of partial melting (Batiza and Vanko, 1984). The alkali basalts also do not show systematic depletions in heavy rare earth elements, as might be expected for melting in the presence of garnet at higher pressure.

\subsubsection{Shimada Seamount}

Shimada seamount is an isolated volcano located on 20 m.y. old crust south of the Clarion Fracture Zone at $16^{\circ} 52^{\prime} \mathrm{N}, 117^{\circ} 28^{\prime} \mathrm{W}$ (Gardner et al., 1984; Fig. 4.1). It is a relatively large volcano which rises more than $3 \mathrm{~km}$ from surrounding seafloor to within $50 \mathrm{~m}$ of the sea surface. 
Figure 4.2 Total alkalies vs. silica for seamount samples studied. Line distinguishes Hawaijan tholeitites from alkali basalts (Macdonald and Katsura, 1964).

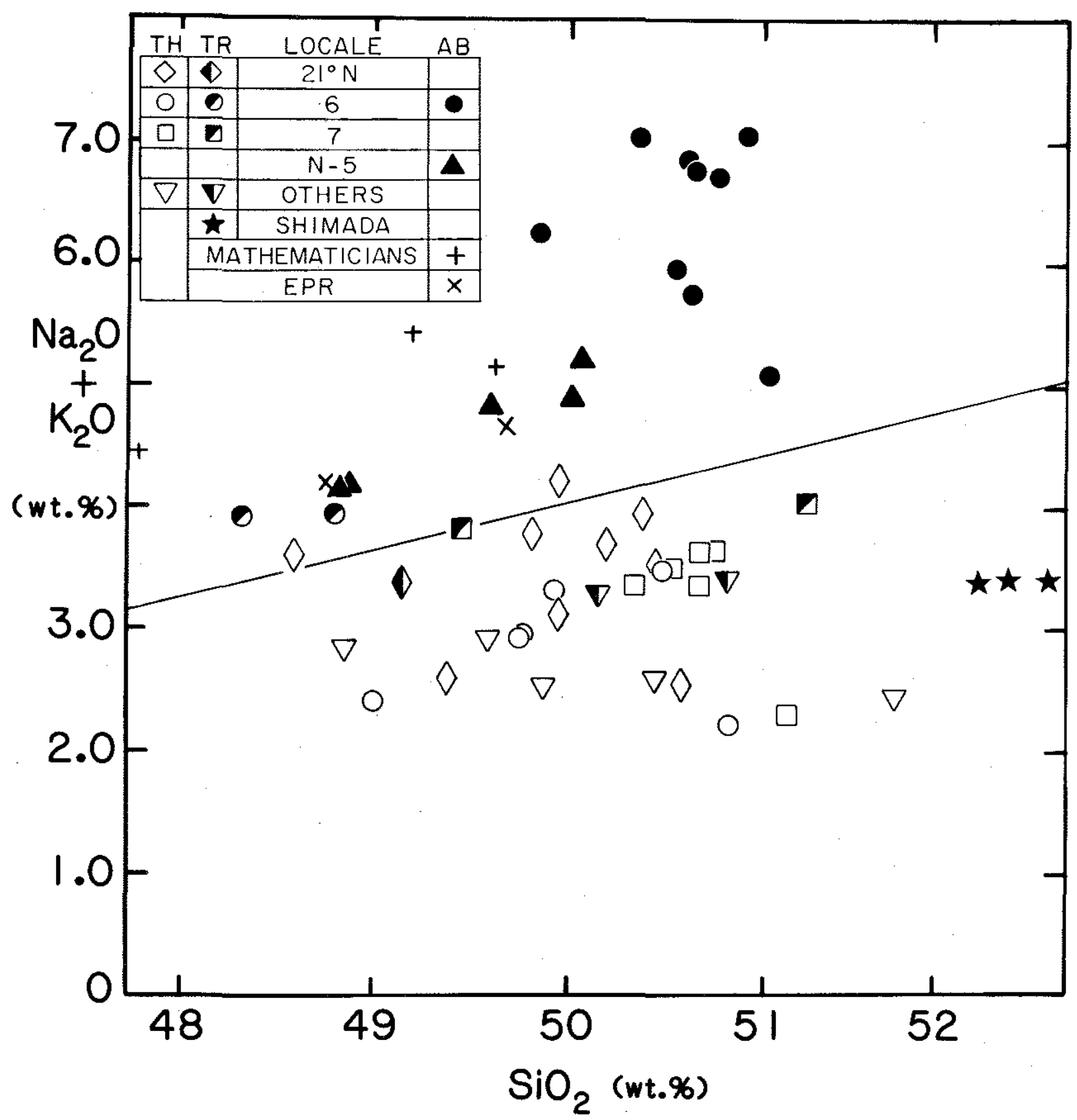


The magnetization direction is not uniform throughout the seamount, and is more complicated than if Shimada seamount had formed near the ridge axis, suggesting episodic evolution (Gardner et al., 1984). Fresh glassy pillow basalts (too young to date by $\mathrm{K} / \mathrm{Ar}$ ) were dredged from the summit; these rocks are classified here as icelandites (basaltic andesites; LeBas et al., 1986) based on total alkalies vs. $\mathrm{SiO}_{2}$ (Fig. 4.2). Shimada seamount's origin and history clearly differ from the EPR seamounts. Shimada seamount may represent either the early phase of a young hotspot, or the later stage of an isolated volcano that is approaching a mid-plate setting.

\subsubsection{Mathematicians Seamounts}

Alkali basalts were erupted at a failed transform seamount along the southern end of the Mathematicians Ridge, following its abandonment as a spreading center before about $6.5 \mathrm{~m} . \mathrm{y}$. ago (Batiza and Vanko, 1985). Two dredges ( $D 1$ and $D 2$ ) recovered primitive rocks ( $M g \#>65$ ) similar to alkali basalts erupted at $\mathrm{N}-5$, one of the small EPR seamounts. Along the northern end of the ridge more differentiated hawaites and trachytes

were dredged from a linear bathymetric feature south of the Clarion Fracture Zone (D9; Fig. 4.1). These rocks were very fresh and some were "popping" when brought on deck (Batiza and Vanko, 1985).

\subsubsection{East Pacific Rise}

Two alkali basalts from the EPR have been studied for comparison with seamount alkali basalts. One sample, SD 8-2 from near the Siqueiros Fracture Zone at $8^{\circ} 24^{\prime} \mathrm{N}$ (Natland and Melson, 1980), is similar in major 
element chemistry (Table 4.2) to an alkali basalt from the same dredge previously analyzed for $S r$ and $N d$ isotopes (Carlson et a T., 1978). A second alkali basalt, R15-56 was recovered from the west wall of the overlapping spreading center near $9^{\circ} 03^{\prime} \mathrm{N}$ (Natland and Macdougall, 1986).

\subsection{Results}

\subsubsection{EPR Seamounts}

$\mathrm{Pb}, \mathrm{Sr}$ and $\mathrm{Nd}$ Isotopes

$\mathrm{Pb}, \mathrm{Sr}$ and $\mathrm{Nd}$ isotope results are given in Table 4.3. All tholeiites are isotopically indistinguishable from typical MORB, consistent with the hypothesis that tholeiites erupted at these seamounts are derived from MORB-type mantle (zindler et a1., 1984). In contrast, the alkali basalts have significantly lower ${ }^{143} \mathrm{Nd} /{ }^{144} \mathrm{Nd}$, and more radiogenic $\mathrm{He}, \mathrm{Pb}$ and $\mathrm{Sr}$ isotope ratios than tholeites. The transitional basalts sometimes show intermediate isotope compositions, but often they resemble the tholeittes. Data from seamount 6 spans most of the observed range in isotope compositions, which is $\sim 50 \%( \pm 10 \%)$ of the observed global variability of MORB (Fig. 4.3-4.6) and more than $80 \%$ of the observed range for Pacific MORB (White et al., 1987). Batiza and Vanko (1984) suggested that the diversity of seamount lavas increases with crustal age, as reflected by the range in $(\mathrm{La} / \mathrm{Sm})_{N}$. In terms of isotopic diversity, ${ }^{206} \mathrm{~Pb} /{ }^{204} \mathrm{~Pb}$ increases with crustal age in seamount alkali basalts (Fig. 4.7); any other isotope trends with age are difficult to discern given the limited number of analyses. 


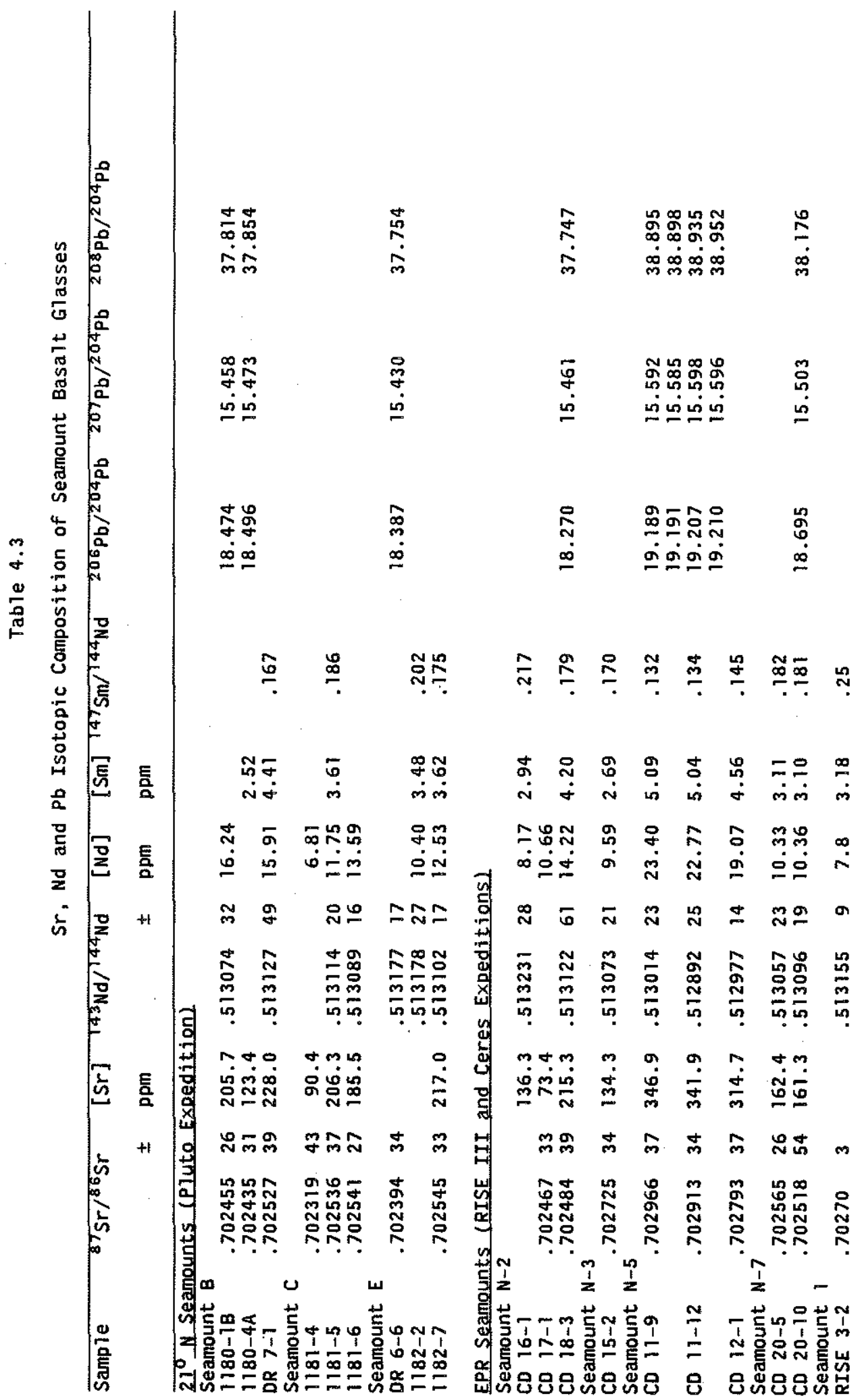




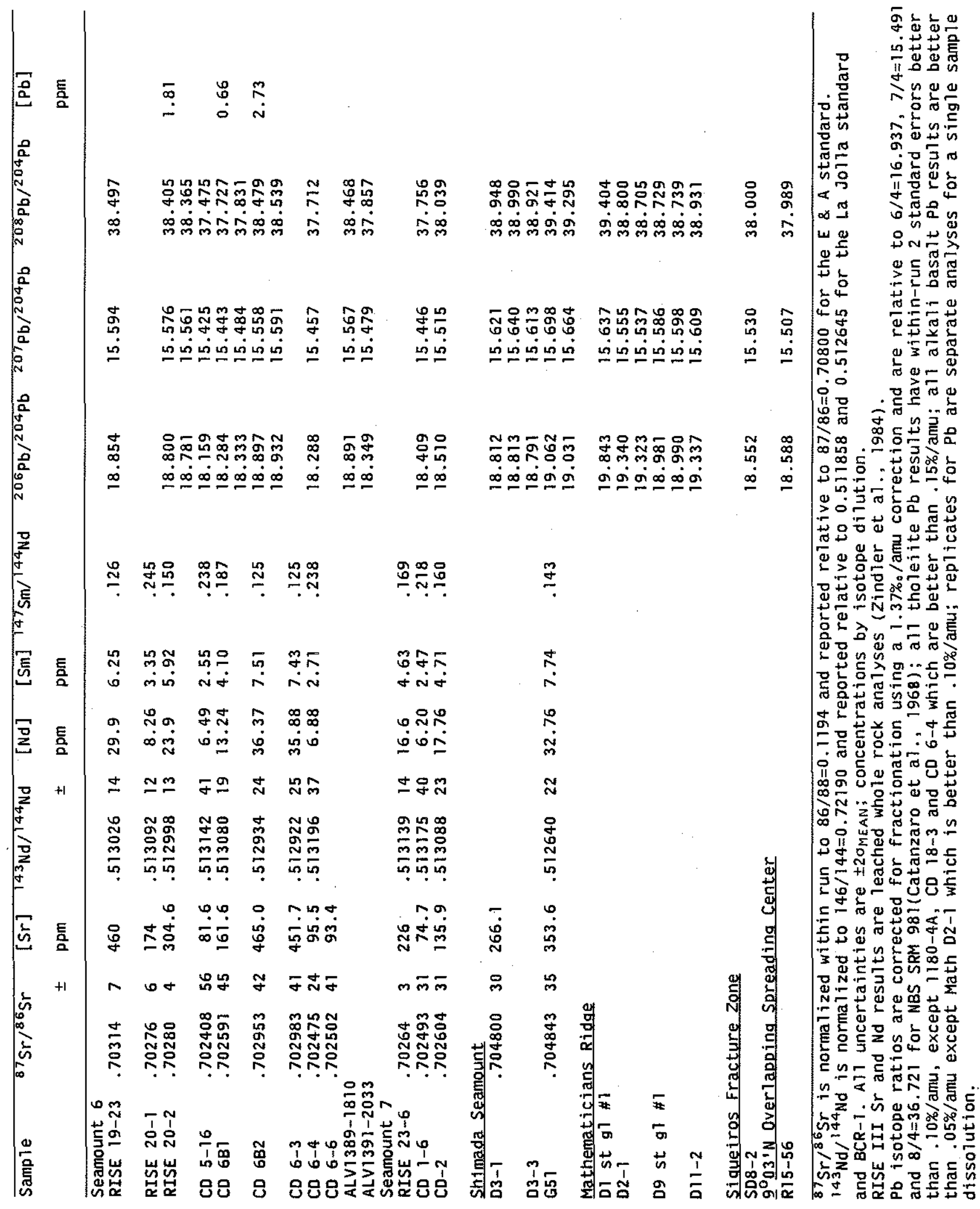


Figure $4.3 \quad$ A. ${ }^{207} \mathrm{~Pb} /{ }^{204} \mathrm{~Pb}$ Vs. ${ }^{206} \mathrm{~Pb} /{ }^{204} \mathrm{~Pb}$ for seamount glasses relative to other Pacific islands.

B. ${ }^{208} \mathrm{~Pb} /{ }^{204} \mathrm{~Pb}$ vs. ${ }^{206} \mathrm{~Pb} /{ }^{204} \mathrm{~Pb}$.

Fields for St. Helena, Walvis Ridge, Kerguelen, Gough, New England Seamounts and MORB are from the compilation by Zindler and Hart (1986a). G K, G K-T and G T are Gorgona komatiites, potassic tholeiites and tholeites, respectively and are from Dupré and Echeverria (1984). $\mathrm{NH}=$ Nuku Hiva and UP=Ua Pou are Marquesas Islands, Mangaia, Atiu, Aitutaki and Rarotonga are Cook Islands, and Tubuaii, Rurutu and Rapa are Austral Islands, from Palacz and Saunders (1986) and Duncan et al. (1986). Northeast Pacific seamount data are from Church and Tatsumoto (1975). 


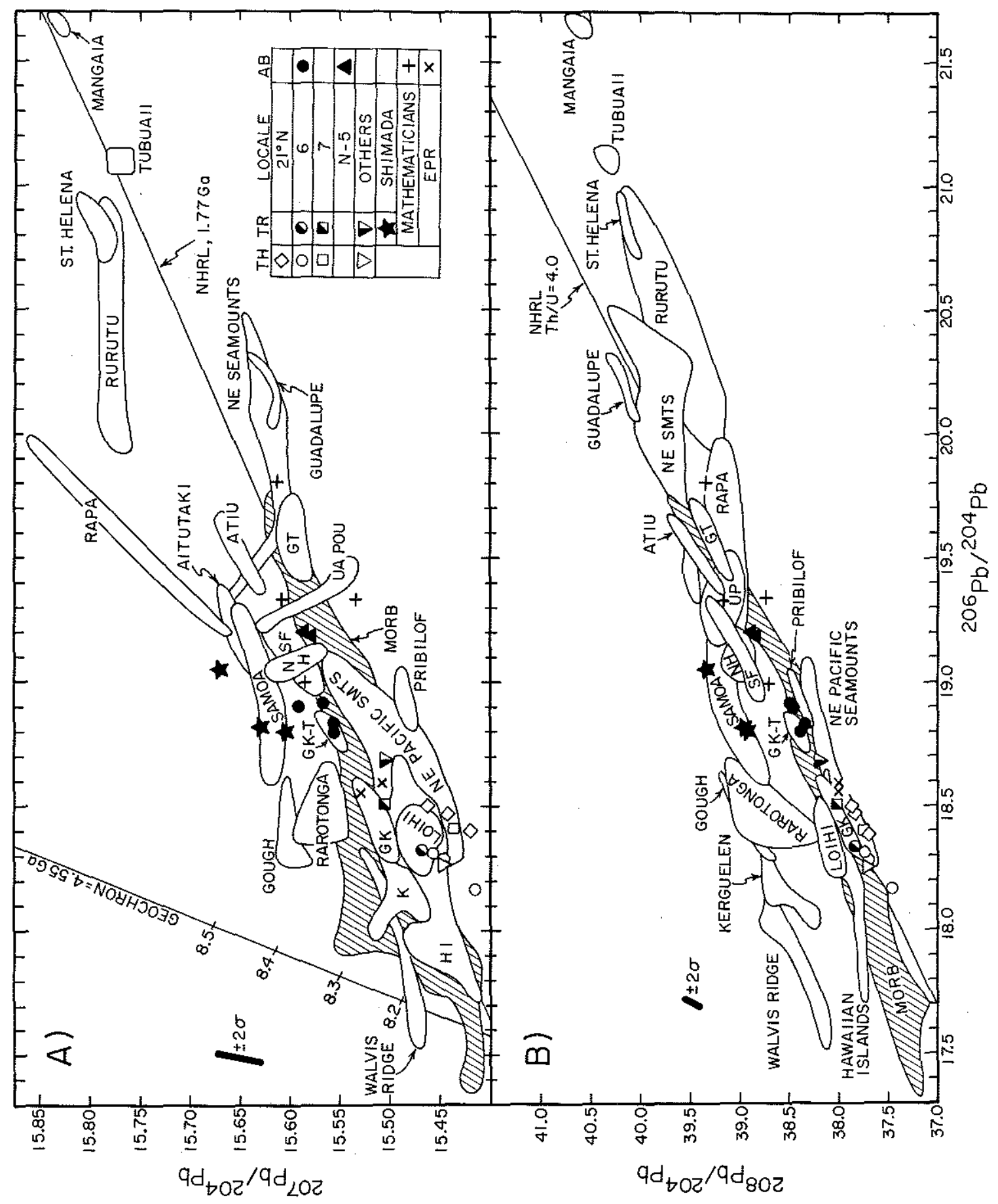


Figure $4.4 \quad{ }^{143} \mathrm{Nd} / /^{144} \mathrm{Nd}$ Vs. ${ }^{87} \mathrm{Sr} /{ }^{86} \mathrm{Sr}$ for the EPR seamounts and Shimada seamount relative to other Pacific islands. Whole rock data from $Z$ indler et a1. (1984) for the EPR seamounts is included. Data are from White and Hofmann (1982), Zindler et al. (1982) and other sources given in Fig. 4.3 . 


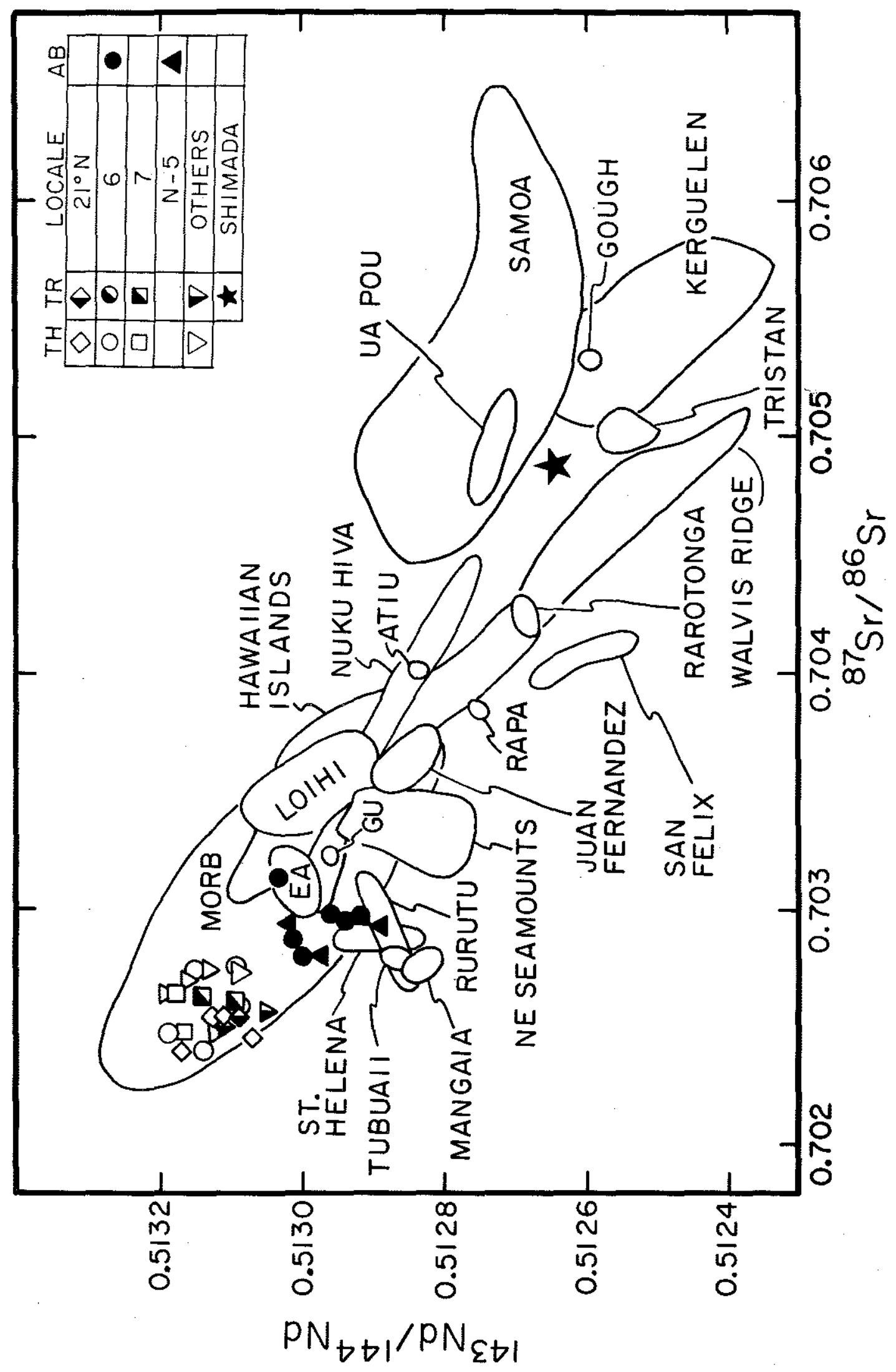




\begin{abstract}
Figure $4.5{ }^{87} \mathrm{Sr} /{ }^{86} \mathrm{Sr}$ vs. ${ }^{206} \mathrm{~Pb} /{ }^{204} \mathrm{~Pb}$ for seamount glasses relative to other Pacific islands. Data from sources as for Fig. 4.3; for Cobb and Hodkins, Pb isotope data is from Kay et al. (1980), and for Sr isotopes from Subbarao et al. (1973). Fields shown are for paired analyses only, except Hodgkins, Cobb, Easter and Guadalupe.
\end{abstract}




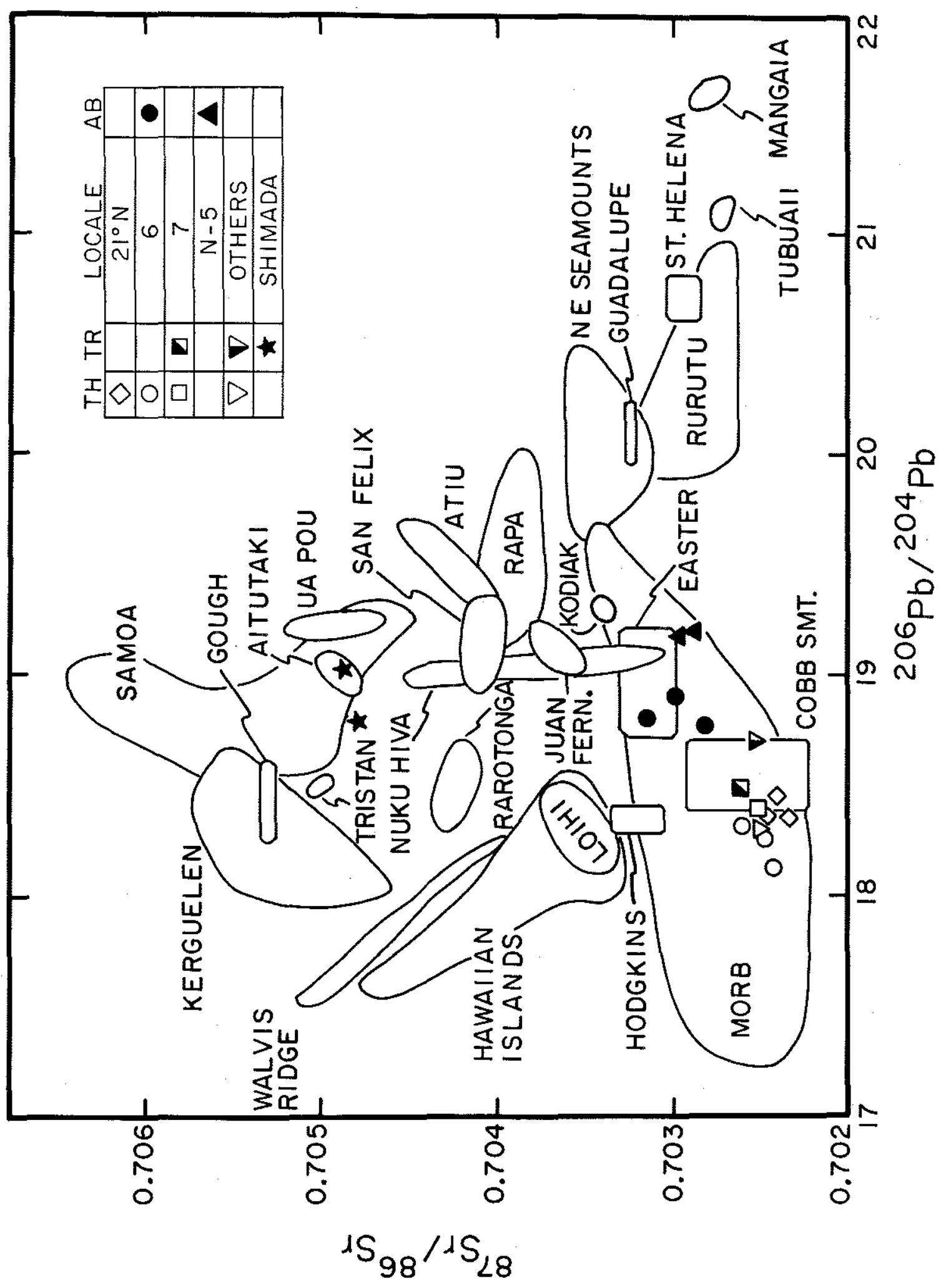


Figure $4.6 \quad{ }^{143} \mathrm{Nd} / /^{144} \mathrm{Nd}$ vs. ${ }^{206} \mathrm{~Pb} /{ }^{204} \mathrm{~Pb}$ for seamount glasses and Pacific islands. 


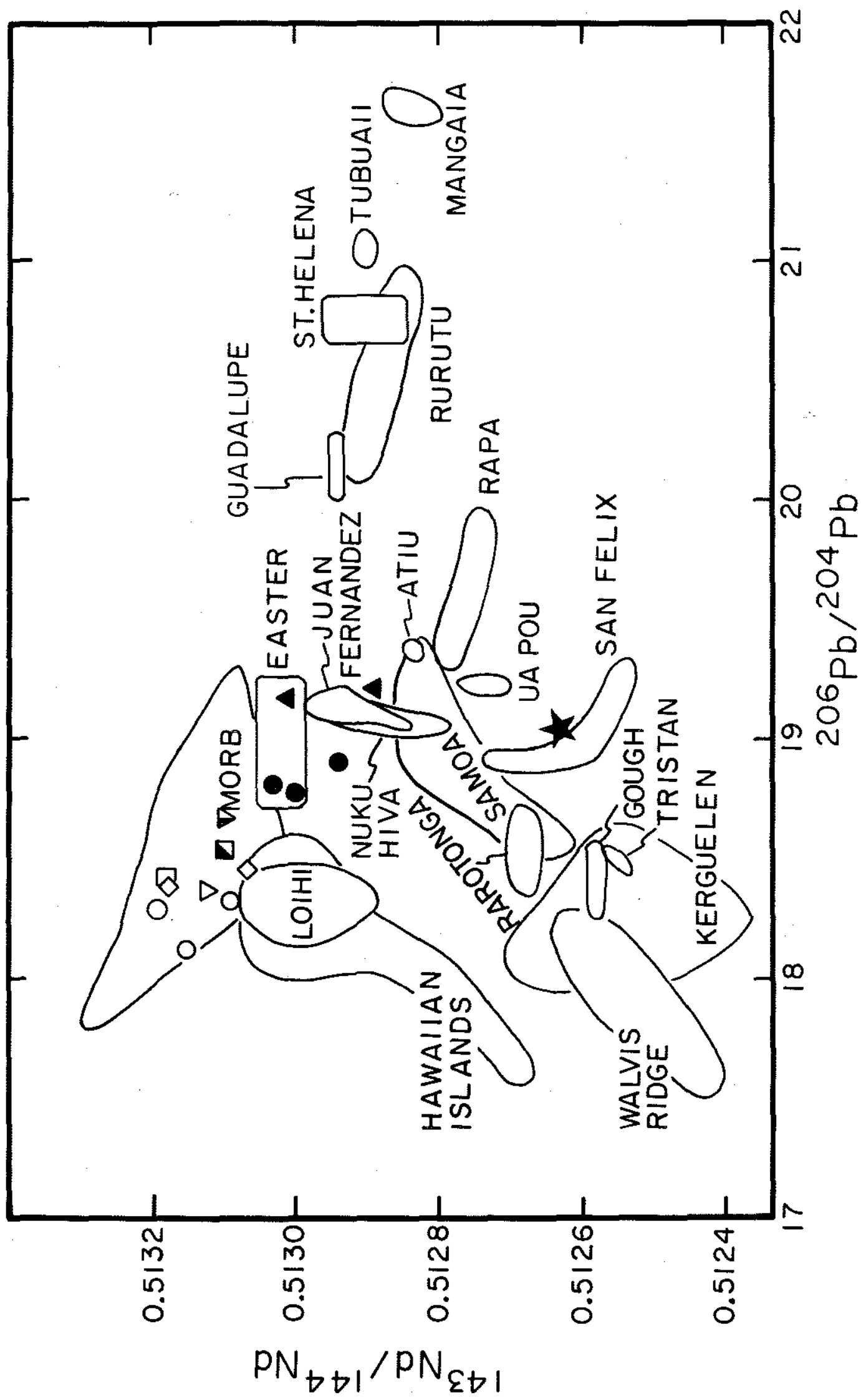




\section{Figure $4.7 \quad \mathrm{~A} .{ }^{3} \mathrm{He} /{ }^{4} \mathrm{He}, \mathrm{B},{ }^{206} \mathrm{~Pb} /{ }^{204} \mathrm{~Pb}, \mathrm{C} .{ }^{87} \mathrm{Sr} /{ }^{86} \mathrm{Sr}$ and D. ${ }^{143} \mathrm{Nd} /{ }^{144} \mathrm{Nd}$ vs. seafloor age. Sample designations as in Fig. 4.3. The circled sample from the Mathematicians Ridge is the popping rock.}




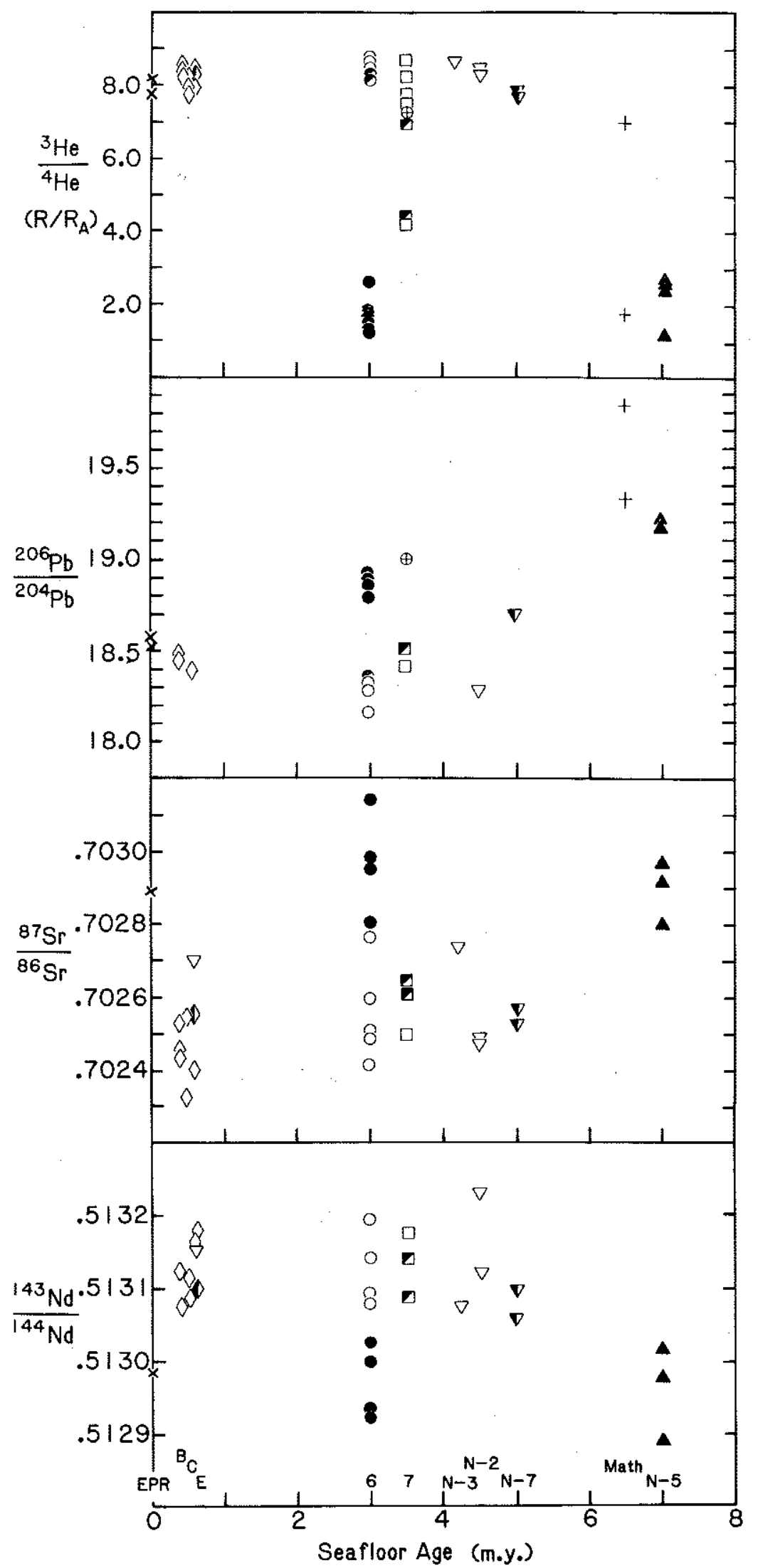


$\mathrm{Pb}$ isotope results are displayed in Fig. 4.3. $\mathrm{Pb}$ isotope compositions for the EPR seamounts are distinct for tholeites and alkali basalts with no overlap, and with alkali basalts always having more radiogenic values. ${ }^{206} \mathrm{~Pb} /{ }^{204} \mathrm{~Pb}$ in tholeites ranges from $18.1-18.5$ and ${ }^{208} \mathrm{~Pb} /{ }^{204} \mathrm{~Pb}$ from $37.4-37.9$; transitional basalts are intermediate and range up to 18.7 and 38.2 , respectively. Alkali basalts range from $18.8-19.2$ in ${ }^{206} \mathrm{~Pb} /{ }^{204} \mathrm{~Pb}$ and from $38.3-39.0$ in ${ }^{208} \mathrm{~Pb} /{ }^{204} \mathrm{~Pb}$, indicating their derivation from a source with higher time-integrated $\mathrm{U} / \mathrm{Pb}$ and $\mathrm{Th} / \mathrm{Pb}$ ratios than the tholeites. Much of the observed range in isotope composition is present at seamount 6 alone. ${ }^{206} \mathrm{~Pb} /{ }^{204} \mathrm{~Pb}$ ratios for the Small EPR seamounts are similar to values for other near axis seamounts in the Pacific, near the Juan de Fuca and Gorda Ridges (Church and Tatsumoto, 1975; Fig. 4.3), but the EPR seamount alkali basalts have slightly higher ${ }^{207} \mathrm{~Pb} /{ }^{204} \mathrm{~Pb}$ and ${ }^{208} \mathrm{~Pb} /{ }^{204} \mathrm{~Pb}$.

Tholeijtes and alkali basalts at these seamounts define distinct fields on the Nd-Sr "mantle array" (Fig. 4.8). The tholeite field is similar to that for MORB erupted at the nearby East Pacific Rise (Macdougall and Lugmair, 1986). The range of $\mathrm{Sr}$ and $\mathrm{Nd}$ isotope compositions in fresh glasses is the same as that previously defined for whole rocks from the same seamount field (Zindler et al., 1984), but ${ }^{87} \mathrm{Sr} /{ }^{86} \mathrm{Sr}$ in some whole rock samples appears systematically higher than values measured in glass samples for equivalent ${ }^{143} \mathrm{Nd} /{ }^{144} \mathrm{Nd}$. This suggests that some of the ${ }^{87} \mathrm{Sr} /{ }^{86} \mathrm{Sr}$ reported for whole rocks may be partly influenced by interaction with seawater. EPR seamount alkali basalts have a range in $\mathrm{Sr}$ and $\mathrm{Nd}$ isotope compositions between values similar to Easter Island and St. Helena. They also encompass Sr and $\mathrm{Nd}$ 


$$
\begin{aligned}
& \text { Figure } 4.8 \quad{ }^{143} \mathrm{Nd} /{ }^{144} \mathrm{Nd} \text { vs. }{ }^{87} \mathrm{Sr} /{ }^{86} \mathrm{Sr} \text { for glasses (GL) and } \\
& \text { whole rocks (WR) for the small EPR seamounts. Also shown } \\
& \text { are data for transitional and alkali basalt glasses from } \\
& \text { the Siqueiros transform (Carlson et al., 1978), and fields } \\
& \text { for MORB glasses from } 12-13^{\circ} \mathrm{N}, 21^{\circ} \mathrm{N} \text {, the Easter } \\
& \text { microplate and two basalts from Easter Island (Macdougall } \\
& \text { and Lugmair, 1986). Mixing curves are shown for } \\
& \text { representative tholeiite and alkali basalt end-members and } \\
& \text { selected } R \text { values }\left(R=(\mathrm{Sr} / \mathrm{Nd})_{A B} /(\mathrm{Sr} / \mathrm{Nd})_{T H}\right) \text {. The } \\
& \text { end-members } \$ 11 \text { ustrated have }{ }^{87} \mathrm{Sr} /{ }^{86} \mathrm{Sr}=0.70230 \\
& \text { (tholeiite) and } 0.70299 \text { (alkali basalt) and }{ }^{143} \mathrm{Nd} /{ }^{144} \mathrm{Nd} \\
& =0.51323 \text { and } 0.51289 \text {, respectively. Measured } R \text { values } \\
& \text { range between } \sim 0.7-1.5 \text {. Tick marks represent } 10 \% \\
& \text { intervals. }
\end{aligned}
$$




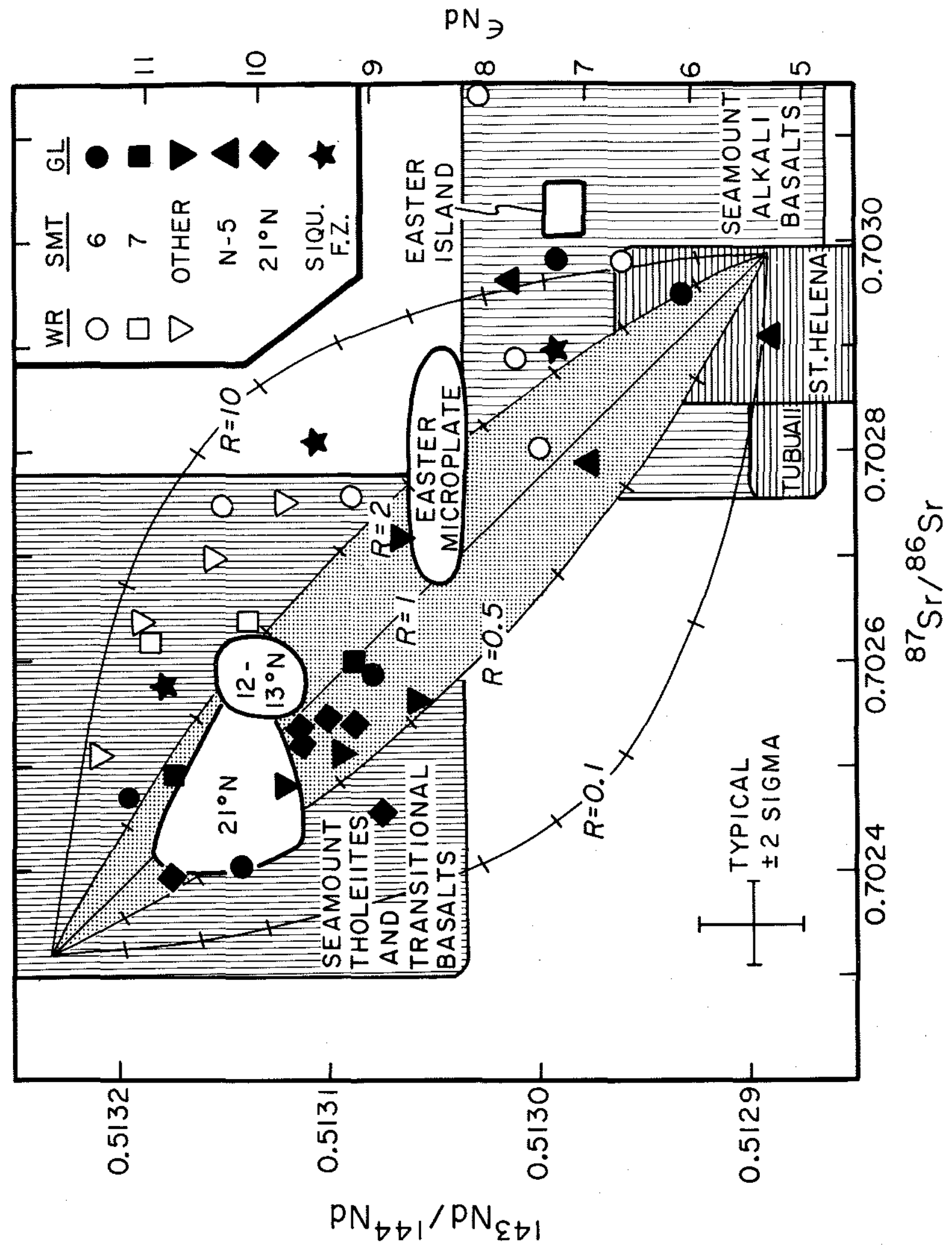


isotope compositions measured for an alkali basalt from the East Pacific Rise near the Siqueiros transform fault (Carlson et al., 1978). Pb isotope compositons for the alkali basalts are within the range of those reported for Easter Island. The scatter in $\mathrm{Pb}-\mathrm{Nd}-\mathrm{Sr}$ isotope compositions indicates that if a binary mixing model is used to explain the observations (Zindler et al., 1984), significant variability in one or both end-members appears to be required.

He Isotopes

He analyses are given in Table 4.4 and displayed in histogram form in Fig. 4.9. Tholeiites range in ${ }^{3} \mathrm{He} /{ }^{4} \mathrm{He}$ from 7.8 to 8.7 times the atmospheric ratio $\left(R_{A}=1.384 \times 10^{-6}\right)$. Transitional lavas sometimes have slightly lower ${ }^{3} \mathrm{He} /{ }^{4} \mathrm{He}$, but of ten are similar to tholeiites.

Transitional basalts range from 7.0-8.2 $R_{A}$. These ranges exclude one transitional basalt (CD-2; $4.3 \mathrm{R}_{\mathrm{A}}$ ) and one tholeifte ( $\mathrm{ALV}$ 1394-1821; $4.3 R_{A}$ ) from seamount 7. A T-test shows the tholeiites (mean ${ }^{3} \mathrm{He} /{ }^{4} \mathrm{He}=8.35 \mathrm{R}_{a}, \sigma=0.23, n=20$ ) to be isotopically indistinguishable from normal MORB (mean ${ }^{3} \mathrm{He} /{ }^{4} \mathrm{He}=8.40 \mathrm{R} a, \sigma=0.36$, $n=32 ; \operatorname{Kurz}, 1982$ ).

The He in vesicles of seamount alkali basalts have lower ${ }^{3} \mathrm{He} /{ }^{4} \mathrm{He}$ ratios, between $1.2-2.6 R_{A}$. A striking feature of the paired crushing-melting results is the observed degree of isotope disequilibrium. In nearly all the seamount alkali basalts and in some transitional lavas, the He dissolved in the glass phase has lower ${ }^{3} \mathrm{He} /{ }^{4} \mathrm{He}$ than that released from the vesicles by crushing. This reflects post-eruptive radiogenic ingrowth of ${ }^{4} \mathrm{He}$ as discussed in chapter 3. He isotope disequilibrium sometimes occurs in the 


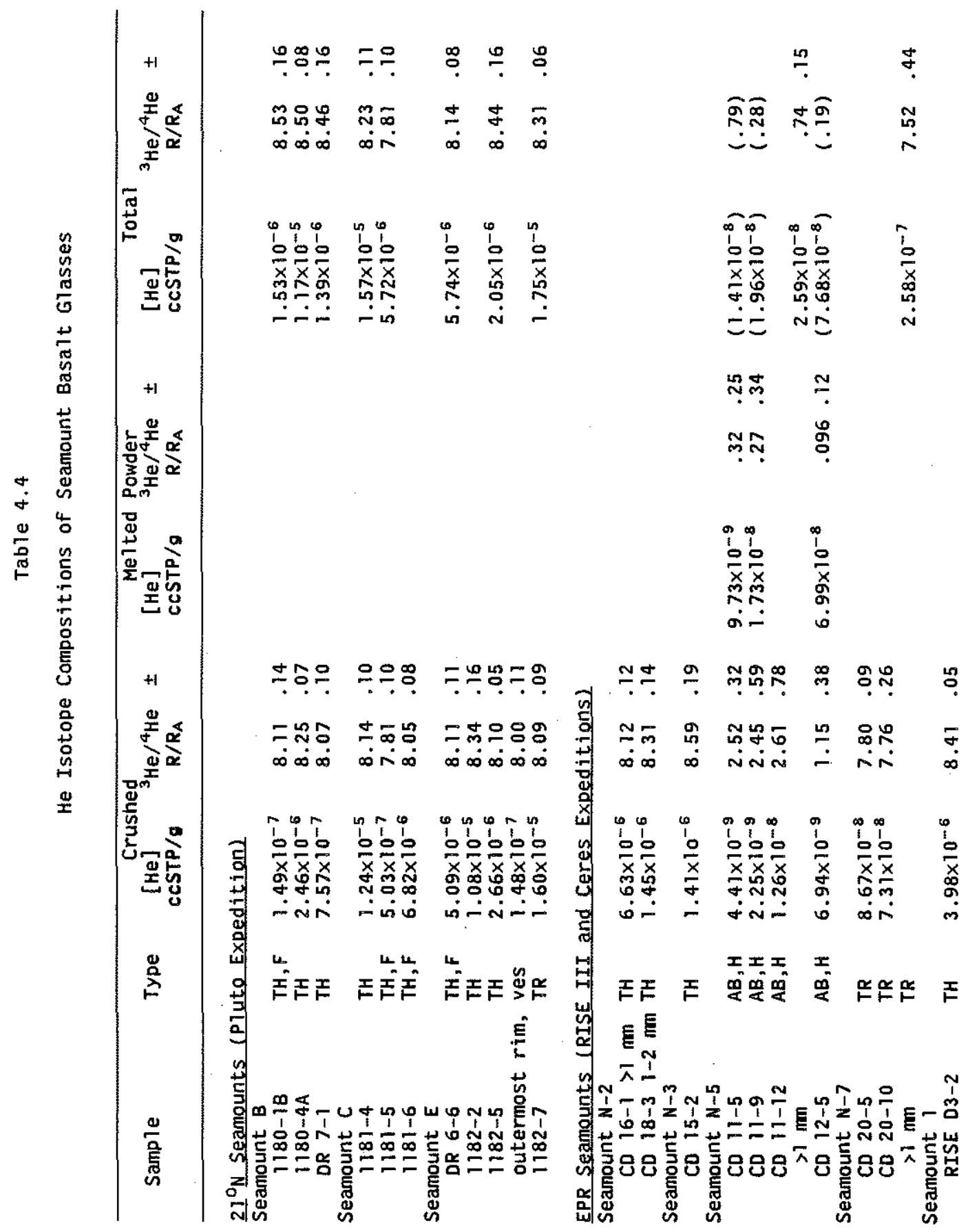




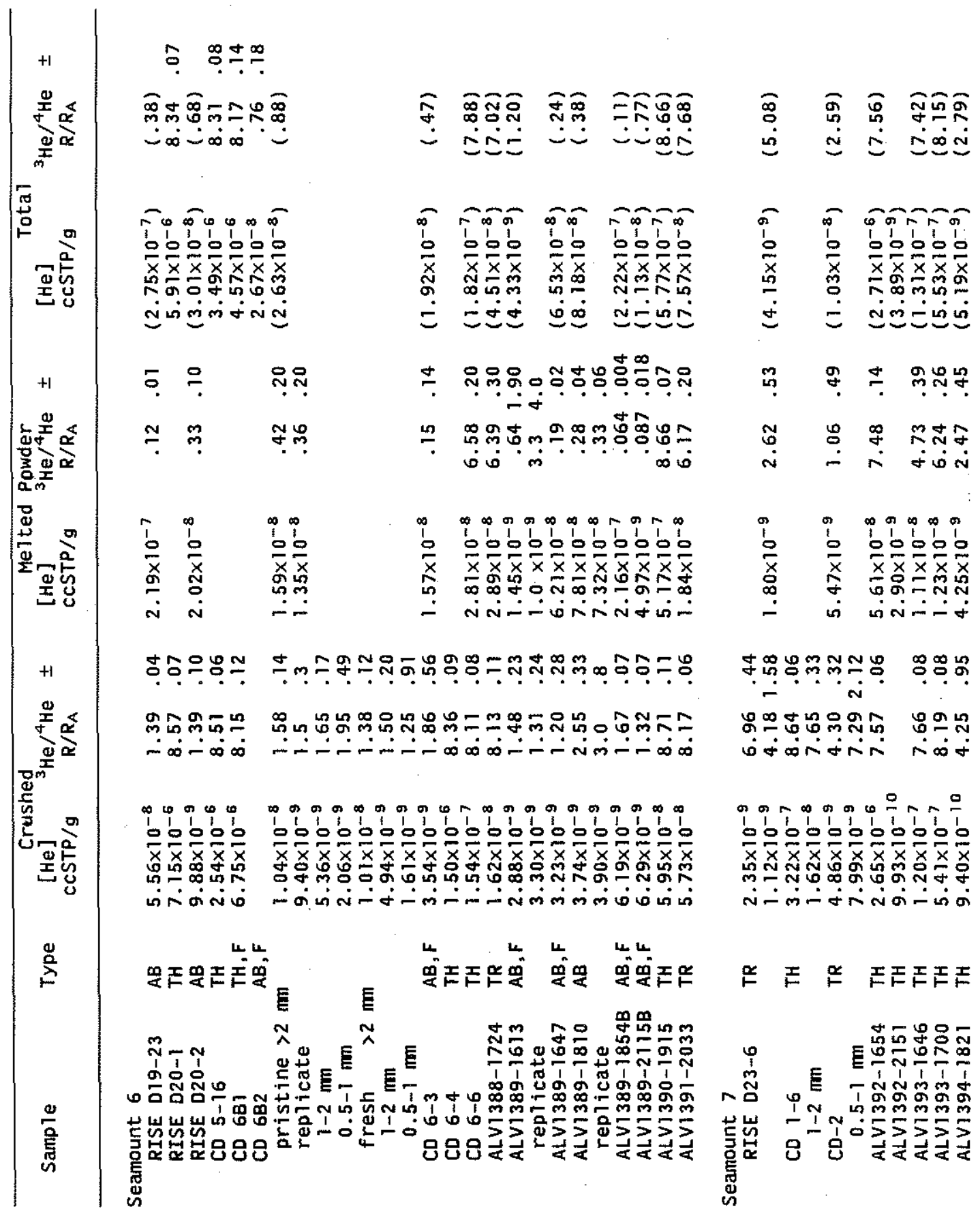




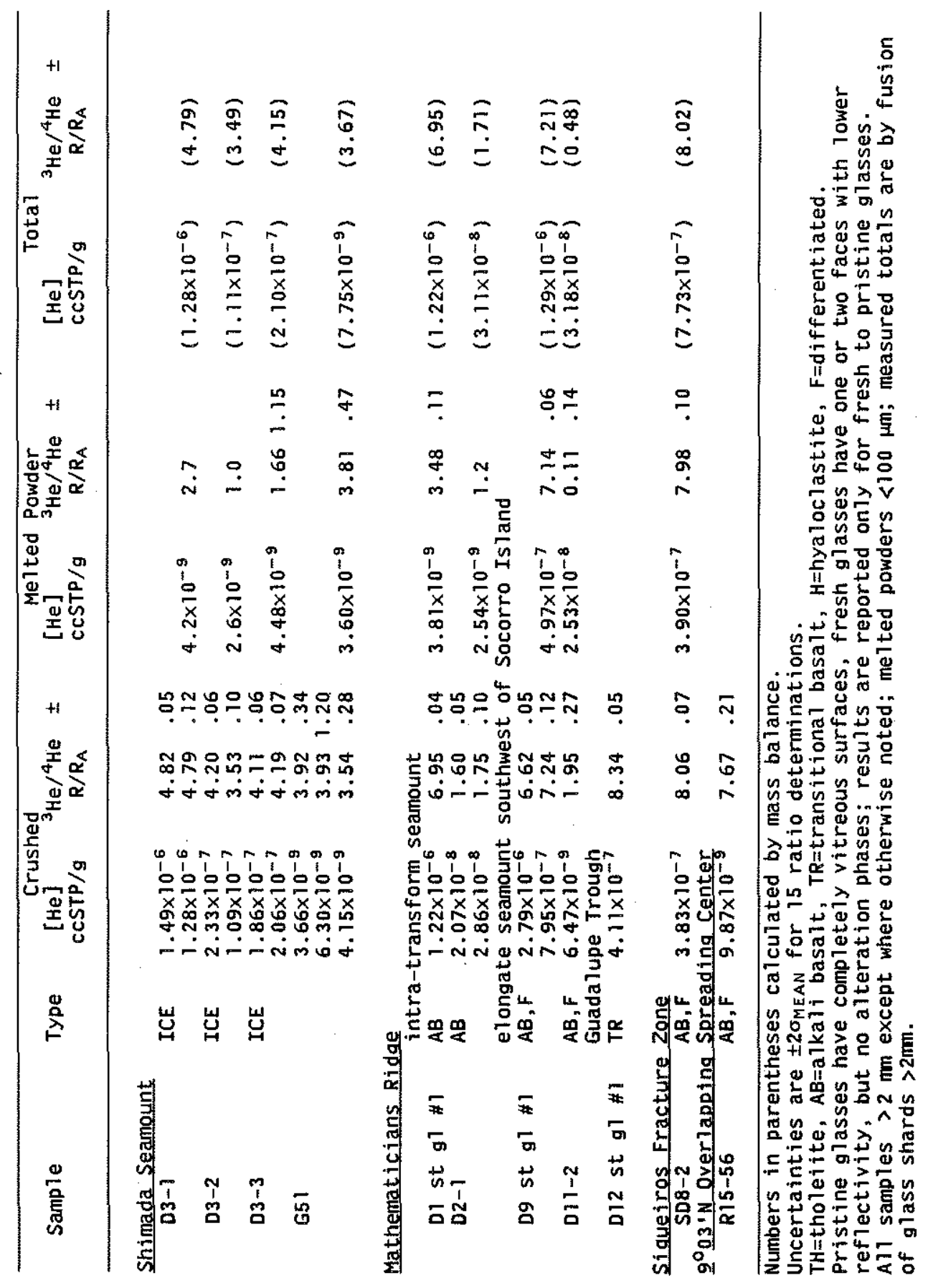


Figure 4.9 Histogram of ${ }^{3} \mathrm{He} /{ }^{4} \mathrm{He}$ in vesicles (released by crushing) and dissolved in the glass phase (released by melting) of tholei ites (open symbols), transitional (half-filled) and alkali basalts (filled) from Pacific seamounts. The circled sample from the Mathematicians is the popping rock. 


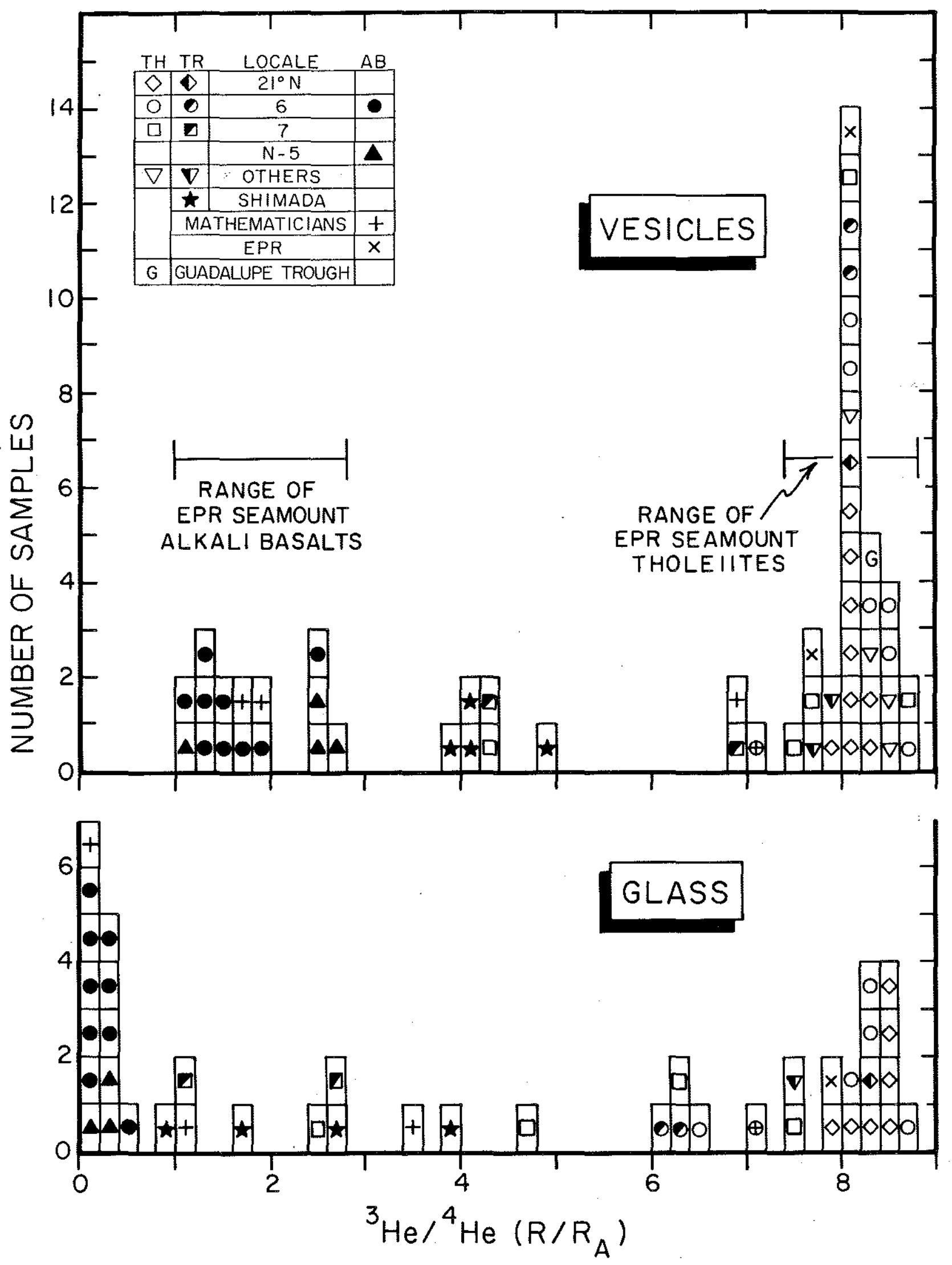


transitional basalts, but estimated ages are often not significantly different from zero (e.g., in seamount 7 basalts), due to very low [He] in the glass and the relatively large uncertainties in $U$ and $T h$ contents. Despite the fact that the alkali basalt ages range from $10^{4}$ to $10^{6} \mathrm{y}$, the ${ }^{3} \mathrm{He} /{ }^{4} \mathrm{He}$ released by crushing is rather uniform, suggesting that the vesicles have retained their magmatic He isotopic signature. Furthermore, inherited He $\left({ }^{3} \mathrm{He}\right)$ in these samples plots near the MORB partitioning curve for a Henry's Law constant $K=3 \times 10^{-4}$ std CC/g-atm (Fig. 3.4).

Fig. 4.10 shows ${ }^{3} \mathrm{He} /{ }^{4} \mathrm{He}$ and [He] vs. Mg \# in samples for which total [He] was measured (determined by the sum of crushing plus melting the remaining powder or by total fusion). The highest He concentrations are associated with the most primitive tholeiites at the $21^{\circ} \mathrm{N}$ seamounts $\left([\mathrm{He}] \simeq 2 \times 10^{-5} \operatorname{ccSTP} / g\right)$, and are comparable to some of the highest values reported for MORB $\left(\simeq 3 \times 10^{-5}\right.$ CCSTP/g; Fisher, 1979; Kurz, 1982). [He] at all three $21^{\circ} \mathrm{N}$ seamounts decreases systematically with

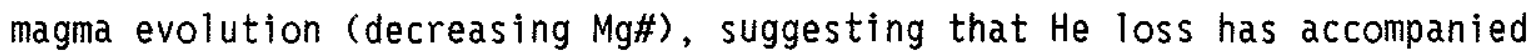
differentiation. Given the low $\left(U_{+} T h\right) / H e$ in these Iavas, systematic variations in ${ }^{3} \mathrm{He} /{ }^{4} \mathrm{He}$ with $\mathrm{Mg \#}$ (e.g., due to radiogenic ingrowth during magmatic differentiation) are not observed. Variations in [He] with Mg\# are not systematic for seamount 6 . The highest $\mathrm{He}$ concentrations at the $9-14^{\circ} \mathrm{N}$ seamounts are $\simeq 7 \times 10^{-6} \mathrm{ccSTP} / \mathrm{g}$ in tholei ites from seamount 6 ; these samples have Mg\# $=60-65$. However, the most primitive tholeite at seamount $6(M g \#=72)$ has a total He concentration approximately ten times lower. 
Figure 4.10 A. ${ }^{3} \mathrm{He} /{ }^{4} \mathrm{He}$ vs. Mg\#. Alkali basalts with higher ${ }^{3} \mathrm{He} /{ }^{4} \mathrm{He}$ are more primitive (Mg\# 62) magmas.

B. Total [He] vs. Mg\#. For transitional and alkali basalts where isotope disequilibrium between vesicles and glass was measured, points are plotted at the measured vesicle [He], and the arrows terminate at the inherited [He] (estimated to reflect the magmatic value upon eruption); inherited $[\mathrm{He}]=[\mathrm{He}]_{\text {ves }}+\left(\mathrm{R}_{\mathrm{g} i} / \mathrm{R}_{\mathrm{ves}}\right)[\mathrm{He}]_{\mathrm{gl}}$. Field for Loihi seamount (data from Kurz et a1., 1983 and Frey and Clague, 1983) is shown for comparison. 


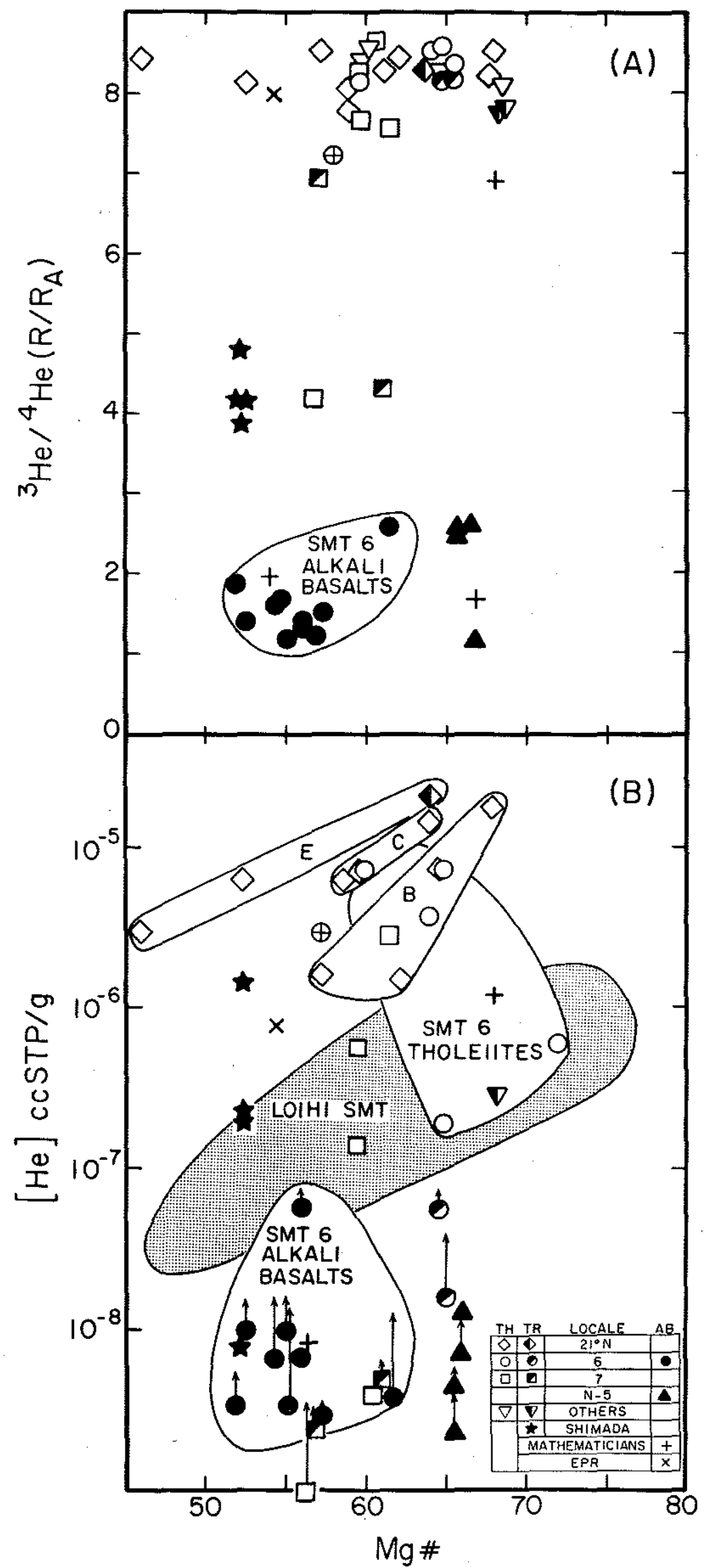


Crushed analyses for alkali basalts from the small EPR seamounts appear to be bimodal, although the number of analyses is limited $(n=13)$. Four of the five primitive alkali basalts $(M g \#>62)$ have ${ }^{3} \mathrm{He} /{ }^{4} \mathrm{He}$ between 2.4-2.6 $R_{A}$ (Fig. 4.10 A). More evolved alkali basalts (Mg\#<58) have lower ${ }^{3} \mathrm{He} /{ }^{4} \mathrm{He}$, between $1.2-1.8 \mathrm{R}_{\mathrm{A}}$, suggesting some degree of magmatic control on ${ }^{3} \mathrm{He} /{ }^{4} \mathrm{He}$ in these samples. The low ${ }^{3} \mathrm{He} /{ }^{4} \mathrm{He}$ in vesicles of alkali basalts is typically associated with low vesicle $[\mathrm{He}]\left(<5 \times 10^{-8} \mathrm{cCSTP} / \mathrm{g}\right)$. Note that this is not the case for other rock types (e.g., Shimada D3-1 and RISE D23-6 from seamount 7).

\subsubsection{Shimada Seamount}

$\mathrm{Pb}, \mathrm{Sr}$ and $\mathrm{Nd}$ Isotopes

Icelandites from Shimada seamount have ${ }^{206} \mathrm{~Pb} /{ }^{204} \mathrm{~Pb}$ comparable to the EPR seamount alkali basalts, but ${ }^{207} \mathrm{~Pb} /{ }^{204} \mathrm{~Pb}(15.6-15.7)$ and ${ }^{208} \mathrm{~Pb} /{ }^{04} \mathrm{~Pb}(38.9-39.3)$ are displaced to higher values (Fig. 4.3). $\mathrm{Sr}$ and $\mathrm{Nd}$ isotope ratios are also distinct $\left({ }^{87} \mathrm{Sr} /{ }^{86} \mathrm{Sr}=.7048\right.$ and $\left.{ }^{143} \mathrm{Nd} /{ }^{144} \mathrm{Nd}=.51268 ; \mathrm{Fig} .4 .4\right)$, and plot near "bulk earth" values on the $\mathrm{Nd}-\mathrm{Sr}$ array. These $\mathrm{Pb}-\mathrm{Sr}-\mathrm{Nd}$ characteristics resemble the enriched mantle component (EM 2; Zindler and Hart, 1986a) which gives rise to post-erosional basalts at Samoa ( $\mathrm{Palacz}$ and Saunders, 1986; Wright and White, 1987; Fig. 4.3-4.6). The high ${ }^{207} \mathrm{~Pb} /{ }^{204} \mathrm{~Pb}$ indicates long-term $(>2 \mathrm{Ga})$ isolation of $\mathrm{Pb}$ in the source region from typical upper mantie material as sampled by MORB. Shimada thus represents the third identified case of "Dupal" signature (Hart, 1984) in the northern hemisphere, along with Sao Miguel in the Azores (Dupré, 1983) and tholei ites from the Koolau shield on Oahu (Stille et al., 1986). 
He Isotopes

${ }^{3} \mathrm{He} /{ }^{4} \mathrm{He}$ ranges from 3.9 to $4.8 \mathrm{R}_{\mathrm{A}}$, and one sample (D3-1) has relatively high [He] $\left(\simeq 1.5 \times 10^{-6} \operatorname{ccSTP} / g\right)$. The lack of significant disequilibrium in samples from Shimada seamount is consistent with its estimated youth and fast growth rate (Gardner et al., 1984). The low ${ }^{3} \mathrm{He} /{ }^{4} \mathrm{He}$ may reflect melting of lithosphere with locally high $\left(U_{+} T h\right) / H e$, but given the [He] in D3-1 a considerable time $(\sim 5$ m.y. $)$ is required for its development (as discussed below). Alternatively, in conjunction with the $\mathrm{Pb}-\mathrm{Sr}-\mathrm{Nd}$ i sotope compositions, the low ${ }^{3} \mathrm{He} /{ }^{4} \mathrm{He}$ is a source characteristic of EM 2 material.

\subsubsection{Mathematicians Seamounts}

$\mathrm{Pb}$ Isotopes

Alkali basalts from the Mathematicians seamounts have ${ }^{206} \mathrm{~Pb} /{ }^{204} \mathrm{~Pb}$ $=19.0-19.8$ (Fig. 4.3), equivalent to the upper $\sim 40 \%$ of the global MORB range, and higher than the most radiogenic values in Pacific MORB ( 19.2; White et al., 1987). Much of this range (19.3-19.8) is found within the intra-transform seamount (D1 and $D 2$ ). The least radiogenic $\mathrm{Pb}$ from along this ridge is found in the "popping rock" (D9).

He Isotopes

An alkali basalt from the intra-transform seamount has low ${ }^{3} \mathrm{He} /{ }^{4} \mathrm{He}$, and shows no significant He isotope disequilibrium, suggesting a very young age. Another alkali basalt from this same seamount (DI) does have higher ${ }^{3} \mathrm{He} /{ }^{4} \mathrm{He}\left(6.9 \mathrm{R}_{\mathrm{A}}\right)$, with significant disequilibrium. ${ }^{3} \mathrm{He} /{ }^{4} \mathrm{He}$ in the glass phase is $3.5 \mathrm{R}_{\mathrm{A}}$, but the [He] is so low $\left(\sim 4 \times 10^{-9} \mathrm{CC} \mathrm{STP/g}\right)$ that its age is not significantly 
different from zero (assuming $U=0.9 \mathrm{ppm}$, estimated from $K / U=1.27 \times 10^{4}$; Jochum et al., 1983). One other alkali basalt (the popping rock, D9) also has ${ }^{3} \mathrm{He} /{ }^{4} \mathrm{He}$ similar to seamount transitional basalts $\left(7.2 R_{A}\right)$, and shows no significant He isotope disequilibrium.

\subsubsection{East Pacific Rise}

$\mathrm{Pb}$ Isotopes

${ }^{206} \mathrm{~Pb} /{ }^{204} \mathrm{~Pb}$ in the two alkali basalts from the EPR (Siqueiros Fracture Zone and $9^{\circ} \mathrm{N}$ overlapping spreading center) are similar, 18.55 and 18.58 , respectively. ${ }^{20.7} \mathrm{~Pb} /{ }^{204} \mathrm{~Pb}(15.51$ and 15.53$)$ and ${ }^{208} \mathrm{~Pb} /{ }^{204} \mathrm{~Pb}(37.99$ and 38.00$)$ also are not significantly different. These values are within the range of MORB and are similar to some of the EPR seamount transitional basalts.

He Isotopes

${ }^{3} \mathrm{He} /{ }^{4} \mathrm{He}$ in EPR alkali basalts is between $7.7-8.1 R_{A}$, within the range of MORB and similar to seamount transitional basalts. The four alkali basalts with highest ${ }^{3} \mathrm{He} /{ }^{4} \mathrm{He}\left(6.6-8.0 \mathrm{R}_{\mathrm{A}}\right)$ are associated with ridge (active and failed) environments (these two EPR alkali basalts and Mathematicians $\mathrm{DI}$ and $\mathrm{Dg})$. Although ${ }^{3} \mathrm{He} /{ }^{4} \mathrm{He}$ ratios are higher in these samples than in alkali basalts of similar composition found at off-axis seamounts, they are, on average, lower than seamount or ridge tholeiites. These ridge alkali basalts have higher [He] and show no significant He isotope disequilibrium, which is consistent with their young age and lower $(U+T h) /$ He relative to samples from off-axis seamounts. 


\section{3 $\mathrm{Pb}, \mathrm{Sr}$ and $\mathrm{Nd}$ Isotope Evidence for Mantle Heterogeneity, End-Member}

Variability and Mixing

Major, trace element and isotopic results for the small EPR seamounts are consistent with derivation of intermediate magma compositions by mixing alkalic and tholeitic end-members. This case can obviously be made more strongly for individual volcanoes than for a seamount field. Isotope relationships for the small EPR seamounts exhibit some degree of bimodality, i.e., fields for tholeijtes and alkali basalts do not significantly overlap. Transitional lavas are often similar to tholeites, possibly due to derivation from a large proportion of that end-member. The implication is that hybrid lavas result from a narrow range of mixing proportions, possibly because the extent of mixing is restricted by dynamic considerations (e.g., density and/or viscosity).

In cases of simple binary mixing, plots of ${ }^{206} \mathrm{~Pb} /{ }^{204} \mathrm{~Pb}$, ${ }^{143} \mathrm{Nd} /{ }^{144} \mathrm{Nd}$ and ${ }^{87} \mathrm{Sr} /{ }^{86} \mathrm{Sr}$ vs. reciprocal concentration will show linear trends (Langmuir et al., 1978). Trends within some rock types from a given seamount (e.g., seamount 7 tholeiites and transitional basalts, seamount 6 alkali basalts) are "semi-linear" (Fig. 4.11). Alkali basalts show steeper trends on these diagrams than do associated tholeites. The wide geographic distribution of samples undoubtedly contributes to some of the scatter. Collectively, the scatter indicates that binary mixing of melts derived from two homogeneous sources does not adequately describe sample compositions. Although the interpretation of Fig. 4.11 is complicated by the effects of the degree of partial melting, 
Figure 4.11 A. ${ }^{143} \mathrm{Nd} / /^{144} \mathrm{Nd}$ vs. $1 /[\mathrm{Nd}]$.

B. ${ }^{87} \mathrm{Sr} /{ }^{86} \mathrm{Sr}$ vs. $1 /[\mathrm{Sr}]$.

Whole rock data from 2 indler et al. (1984) is included. 

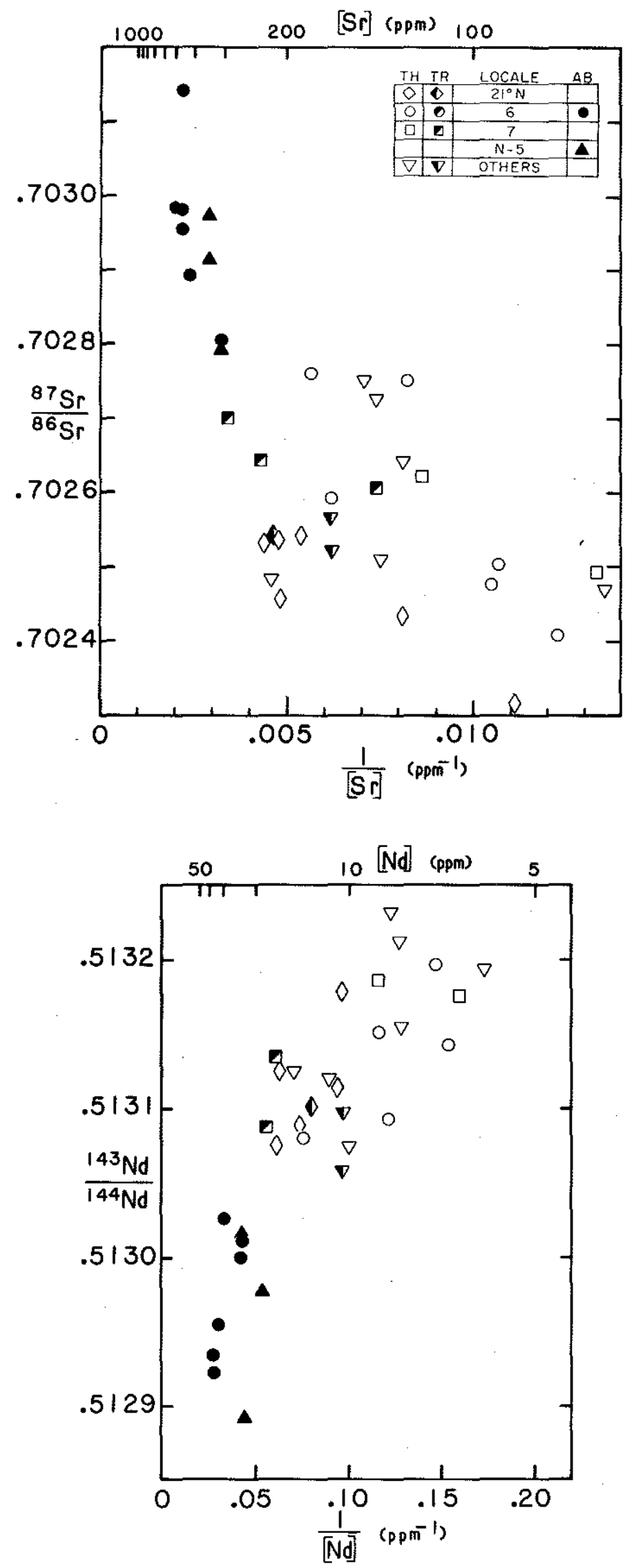

$-109-$ 
fractional crystallization and variability in source composition (and in the case of $\mathrm{Sr}$, possible small amounts of seawater contamination), several pertinent observations can be made. Firstly, there is considerable range of values within the alkali basalts from seamount 6 alone. Secondly, seamount 6 hawaites and the primitive alkali basalts from $\mathrm{N}-5$ plot very near each other on these diagrams. To derive the seamount 6 alkali basalts by fractional crystallization of an $\mathrm{N}-5$ parent magma requires $\sim 40 \%$ crystallization (Batiza and Vanko, 1984); Nd and $\mathrm{Sr}$ concentrations should be larger in seamount 6 alkali basalts with respect to those from $\mathrm{N}-5$ (by a factor of $\sim 2.5$ ). On average, they are higher by $\sim 50 \%$. Therefore, both partial melting and fractional crystallization effects have likely contributed to the differences in [Nd] and [Sr] between seamount 6 and $\mathrm{N}-5$ alkali basalts. Given a source region that is heterogeneous on the scale of sampled melts, different extents of melting might produce an isotopically variable alkalic end-member beneath these seamounts. In addition, the source for alkali basalts from seamounts 6 and $N-5$ may be different. Thirdly, the slopes for seamounts 6,7 and the $21^{\circ} \mathrm{N}$ seamounts are different (Fig. 4.11), and the trend for seamount 6 basalts considered collectively is distinctly non-linear. This also suggests a more complicated history than simple binary mixing. Overall either 1) the sources giving rise to the end-member magmas are compositionally heterogeneous, 2) some degree of solid-liquid mixing has occurred and/or 3) end-member magmas show variable trace element enrichments, due to different extents of partial melting in the source regions. 
Extrapolation to zero values of reciprocal concentration allows crude estimates for end-member compositions, but the steepness of the alkali basalt arrays on Fig. 4.11 introduces too large an uncertainty for the estimates to be meaningful. In a simple binary mixing model, the linear trend for ${ }^{205} \mathrm{~Pb} /{ }^{204} \mathrm{~Pb}$ vs. $1 /[\mathrm{Pb}]$ in seamount 6 basalts would suggest end-member ${ }^{206} \mathrm{~Pb} /{ }^{204} \mathrm{~Pb}$ near 19.1 (Fig. 4.12) similar to values measured at $\mathrm{N}-5(19.2)$. These $[\mathrm{Pb}]$ results are not very conclusive due to the limited data set. However, if the sources for alkali basalts at seamount 6 and $\mathrm{N}-5$ have similar $\mathrm{Pb}$ isotopic compositions, then the most radiogenic $\mathrm{Pb}$ values measured (at $\mathrm{N}-5$ ) may be roughly similar to relatively unmodified source values.

Zindler et al. (1979) suggested that limiting cases for isotope variability can be described by the presence of large-scale, old mantle heterogeneities which mix in the melted state (LOM), or by smal1-scale, old heterogeneities which mix in the solid state (SOS). As amplified by Richardson et a1. (1982), magmas derived from a composite source with either of these characteristics (where the heterogeneities had the same isotopic composition at some time in the past) will describe similar $\mathrm{Pb}-\mathrm{Sr}-\mathrm{Nd}$ and $\mathrm{Pb}-\mathrm{Pb}$ isotope correlations, and similar correlations with reciprocal concentrations and parent/daughter ratios. However, in the SOS model the "isochron" diagrams may have more age significance. Fig. 4.13 and 4.14 show $\mathrm{Sm} / \mathrm{Nd}$ and $\mathrm{U} / \mathrm{Pb}$ isochrons for samples on which parent/daughter ratios have been determined. Results for $\mathrm{U} / \mathrm{Pb}$ at seamount 6 are correlated and give an apparent "age" near $150 \mathrm{~m} . \mathrm{y}$. , similar to the regional correlation observed in Pacific MORB glasses (Fig. 4.14; Cohen et al., 1980; Cohen and 0'Nions, 1982a; White et al., 
Figure $4.12^{206} \mathrm{~Pb} /{ }^{204} \mathrm{~Pb}$ vs. $1 /[\mathrm{Pb}]$ for the three seamount 6 basalts where $[\mathrm{Pb}]$ was measured by isotope dilution. [U] is from Batiza and Vanko (1984). 


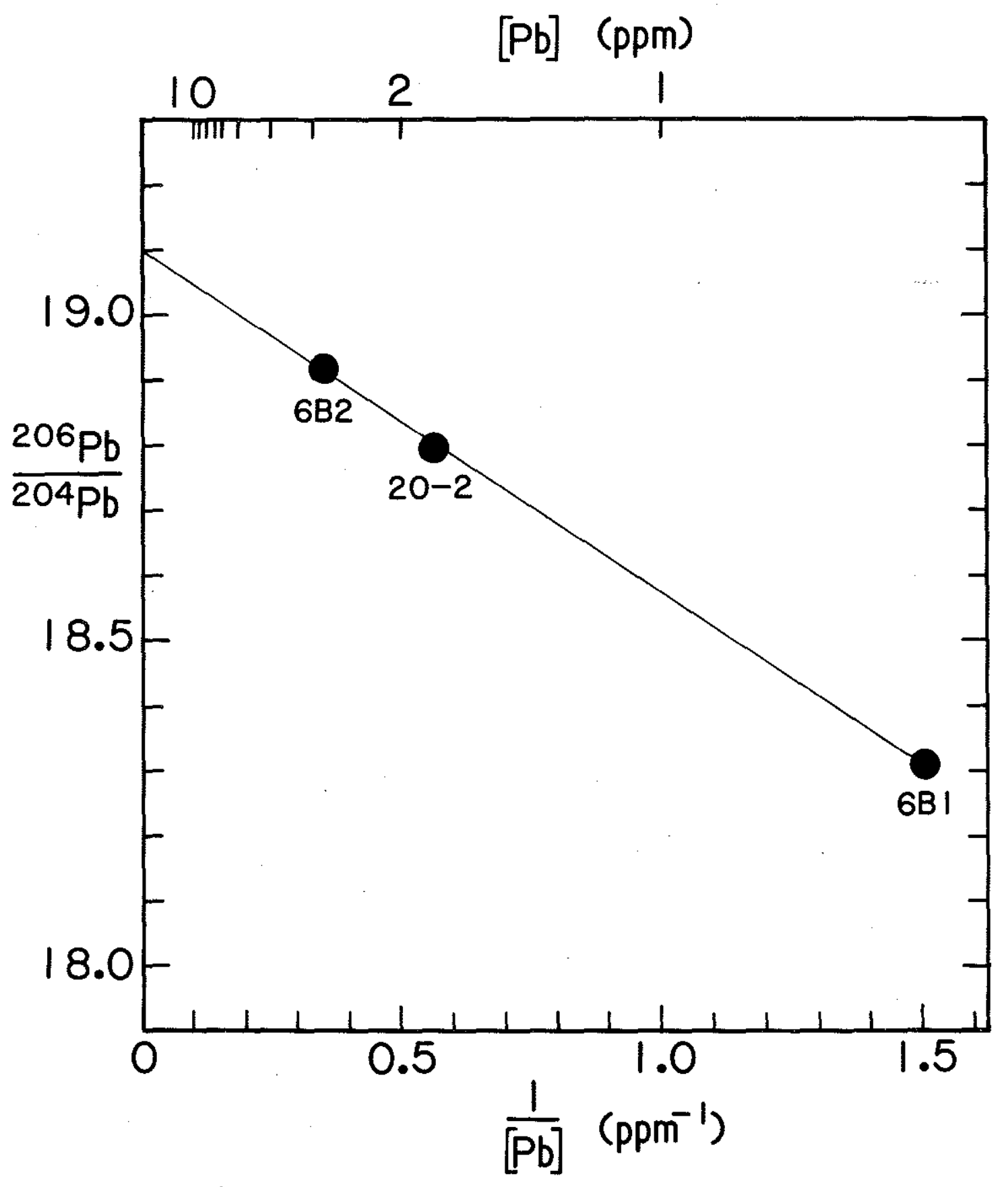


Figure 4.13 Sm-Nd "isochron" diagram for small EPR seamounts. 


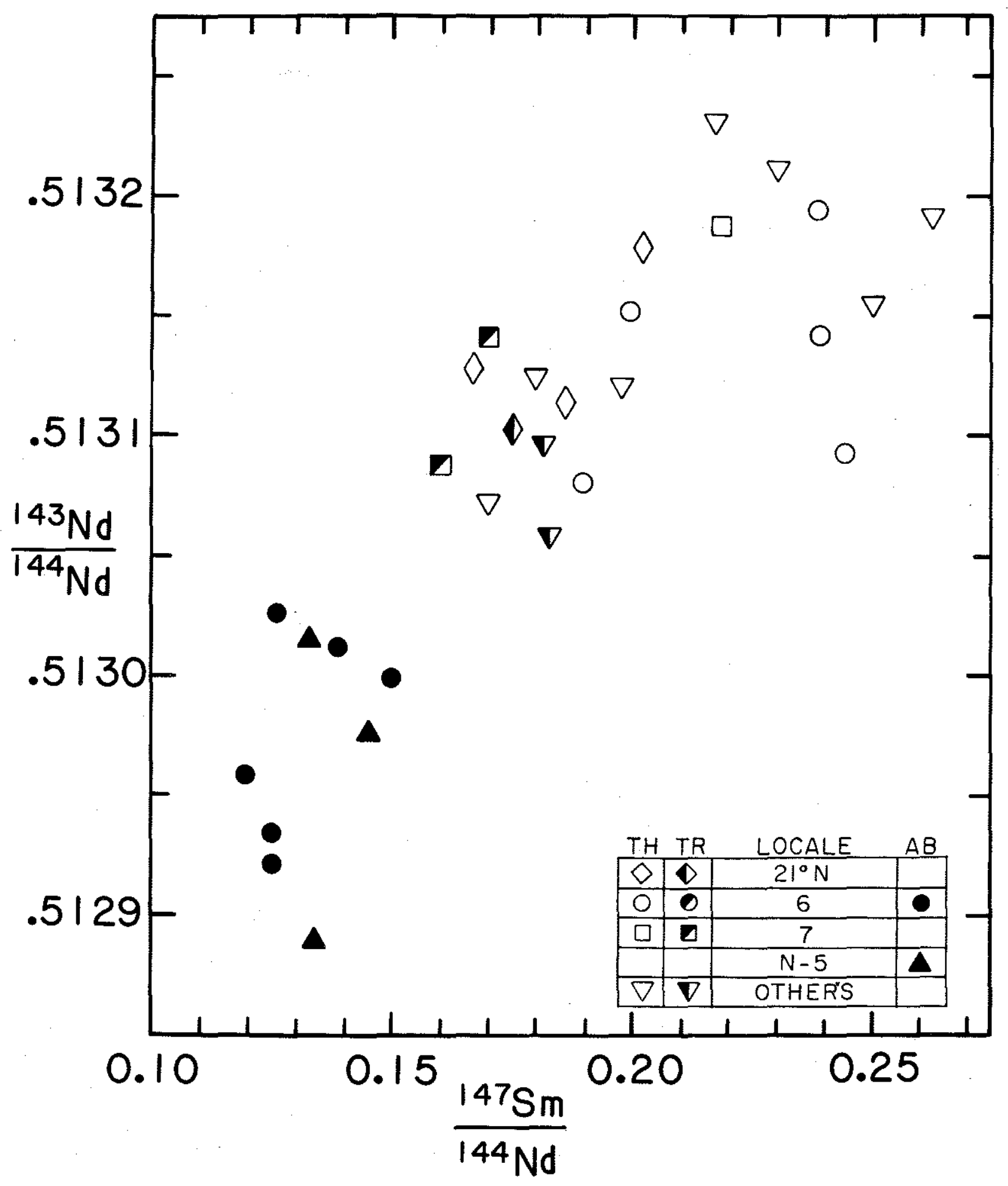


Figure 4.14 U-Pb "isochron" diagram. Line shown is for seamount 6 samples only. Other Pacific MORB glass data is from Cohen et a1. (1980), Cohen and O'Nions (1982a) and White et al. (1987); northeast Pacific seamount data are whole rock analyses from Church and Tatsumoto (1975). seamount 6; O Galapagos spreading center; $\square$ Juan de Fuca Ridge; - Juan de Fuca and Gorda seamounts; $\Delta$, other Pacific MORB. [U] for seamount 6 from Batiza and Vanko (1984). 


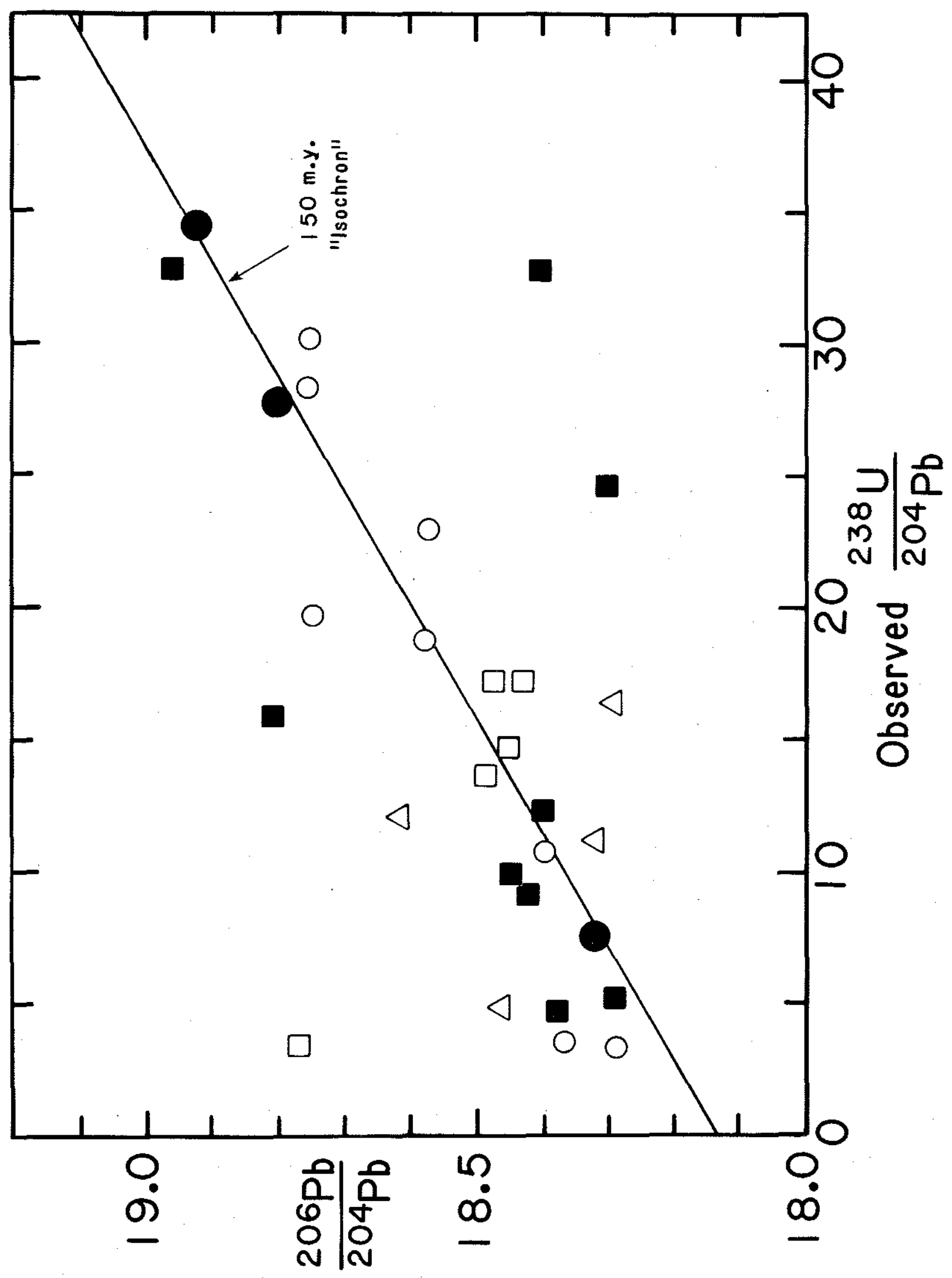


1987). This U/Pb "age" is similar in magnitude to that calculated from the slope of ${ }^{207} \mathrm{~Pb} /{ }^{204} \mathrm{~Pb}-{ }^{206} \mathrm{~Pb} /{ }^{204} \mathrm{~Pb}$ for seamount alkali basalts (Fig. 4.3, $990 \mathrm{~m} . \mathrm{y} . ;$ see below) but much different from consideration of all seamount $\mathrm{Pb}$ data $(\sim 2.5 \mathrm{Ga})$. The $\mathrm{Sm} / \mathrm{Nd}$ "age" for seamount 6 glasses is 260 m.y. (Fig. 4.13), similar to that previously calculated by Zindler et al. (1984) for both $\mathrm{Sm} / \mathrm{Nd}$ and $\mathrm{Rb} / \mathrm{Sr}$ in whole rocks, but the results again show considerable scatter, due to the complexities discussed above.

$\mathrm{Pb}-\mathrm{Pb}$ secondary isochron ages and associated parameters are given in Table 4.5 for Shimada seamount, for seamount 6 , for the EPR seamount tholeites and alkali basalts considered independently, and for all the EPR seamount data collectively. Multi-stage or quasi-continuous evolutionary histories for the source regions of these magmas are more likely than these two-stage histories, as evidenced by the correlation between $(\mathrm{La} / \mathrm{Sm})_{\mathrm{N}}$ and ${ }^{206} \mathrm{~Pb} /{ }^{204} \mathrm{~Pb}(\mathrm{Fig} .4 .15)$. Because several episodes of melting are needed to fractionate La/Sm, this correlation suggests that the isotope variations may be the result of a progressive process (Allegre et al., 1980). It also indicates that the extent of melting may be a dominant control on the $\mathrm{Pb}$ isotope composition of magmas generated in this region. Nevertheless, episodic models of isotope evolution reveal several intriguing aspects. Firstly, as is usual for oceanic basalts, the secondary $\mu(U / P b)$ values are always higher than the primary values, which cluster around a value of 7.9 (Chase, 1981). The small EPR seamount lavas considered collectively give an "age" of 2.6 Ga, while the alkali basalts give an "age" of $90 \mathrm{~m} . y$. . These results contrast with the $\mathrm{Rb} / \mathrm{Sr}$ and $\mathrm{Sm} / \mathrm{Nd}$ "isochron ages" of $\sim 0.25 \mathrm{Ga}$. 
Figure $4.15(\mathrm{La} / \mathrm{Sm})_{\mathrm{N}}$ vs. ${ }^{206} \mathrm{~Pb} /{ }^{204} \mathrm{~Pb} .(\mathrm{La} / \mathrm{Sm})_{\mathrm{N}}$ from Batiza and Vanko (1984), (1985) and Smith (1987). 


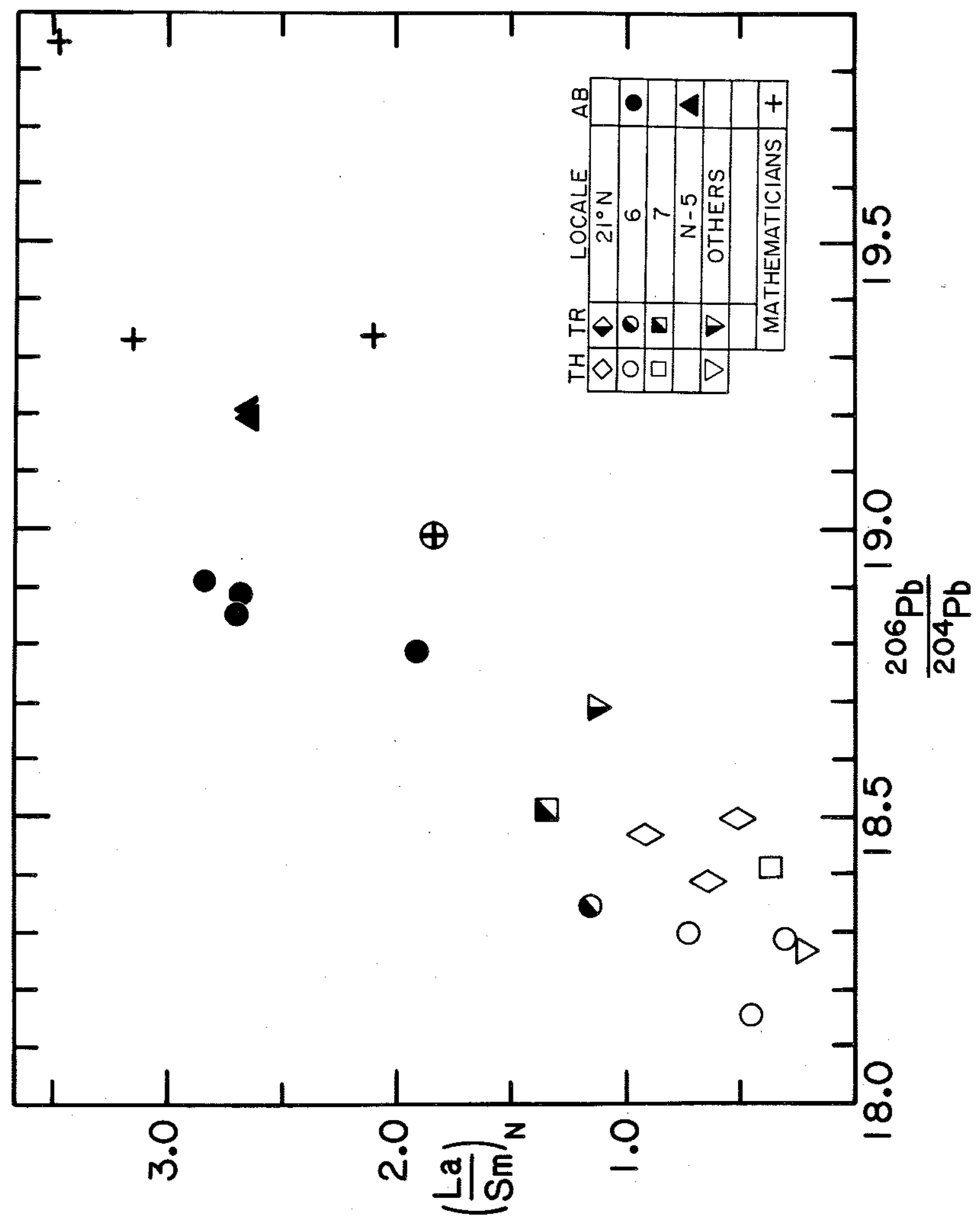




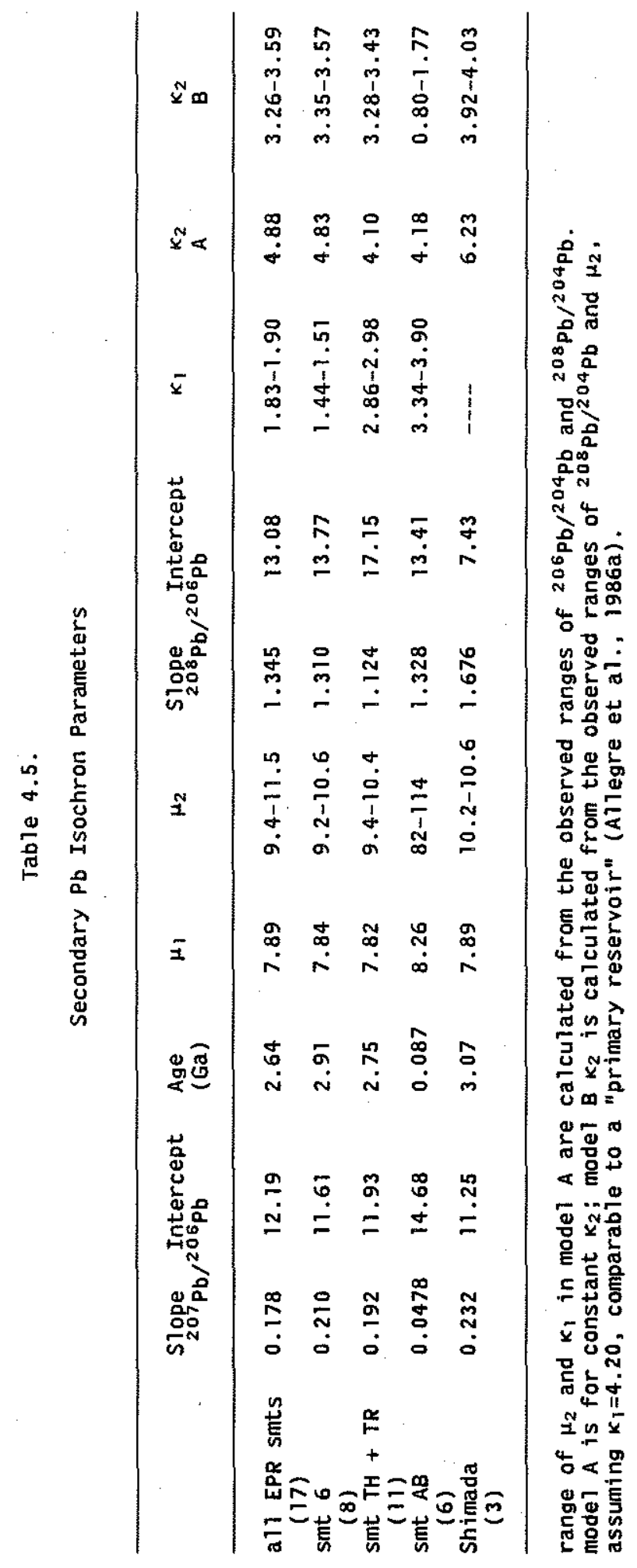


Obviously these results cannot be solely indicative of closed-system mantle aging, but instead are an artifact of the mixing process (see also Zindler et a1., 1984). Secondly, I considered two cases for modelling the Th/U ratio. For constant $\kappa$ in the second stage (model A; Table 4.5), ${ }^{208} \mathrm{~Pb} /{ }^{208} \mathrm{~Pb}$ requires an increase in $\mathrm{k}$ from first stage values much less than 4.2 . ${ }^{208} \mathrm{~Pb} /{ }^{204} \mathrm{~Pb}$ at Shimada seamount cannot be accomodated by such a model. The assumption of constant $k$ is unreasonable however, since processes which fractionate $\mu$ should fractionate $\kappa$, and produce variable $\kappa$ in the second stage (see White et a1., 1987). For the case where the various subsystems fractionated from a reservoir with $\kappa_{1}=4.20$ (model $B$ ), similar to that for a "primary reservoir" (Allègre et al., 1986a), one obtains second stage $k$ values higher than those estimated for depleted upper mantle $(\sim 2.5$, as deduced from Th-U isotopic systematics in MORB; Allègre and Condomines, 1982). In contrast to mode1 $\mathrm{A}$, this model requires lower second stage $\kappa$ values. Measurements of Th-U isotopic disequilibrium are required for more definitive statements concerning $T h / U$ in the source regions. Allègre et a1. (1980) showed that straight line correlations and oceanic basalt-type $\mathrm{Pb}$ can result from continuous fractionation of $\mathrm{U} / \mathrm{Pb}$ within the mantle and subsequent mixing. In their model of variable volume mantle domains all $\mathrm{Pb}-\mathrm{Pb}$ "isochrons" younger than $2.6 \mathrm{Ga}$ required isotopic exchange between domains in addition to mixing; this exchange will increase as the size of domains decrease. Perhaps the lower "age" for the EPR seamount alkali basalts considered alone $\left(\sim 10^{8}\right.$ y) reflects the scale of isotopic heterogeneity and the extent of melting in the underlying mantle. That is, at smaller scales of sampling by the 
melt generation process, exchange by diffusion becomes more readily detectable, because these "marble cake layers" have been significantly thinned down by convective strain during residence in the upper mantle (Allègre and Turcotte, 1986; Gurnis, 1986). When mixing between a MORB component and these heterogeneous domains occurs, it generates apparent isochrons of $\sim 2.5 \mathrm{Ga}$. The diffusion coefficient for $\mathrm{Pb}$ in mantle materials is not well known, but is likely between $10^{-10}$ to $10^{-13}$ $\mathrm{cm}^{2} / \mathrm{s}$ in solids and about $10^{-7} \mathrm{~cm}^{2} / \mathrm{s}$ in melts (Hofmann and Hart (1978). If the small-scale domains are incompletely homogenized by diffusion (as suggested by the isotopic variability) and are approximately $2.5 \mathrm{Ga}$ old, they would have scale lengths on the order of 1-30 $\mathrm{m}$. An upper limit is $\sim 1 \mathrm{~km}$ if these domains are partially molten.

\subsection{Implications for Distribution of Heterogeneities}

$\mathrm{Sr}, \mathrm{Nd}$ and $\mathrm{Pb}$ isotope results are compared in Fig. 4.3-4.6. Multi-isotopic projections permit the identification of mantle domains with similar long-term geochemical histories. Such comparisons also help to identify processes responsible for the isotope characteristics of oceanic islands, because it is unlikely that widely dissimilar processes produce similar multi-isotopic characteristics in different geographic regions. With respect to the EPR seamounts, all $\mathrm{Pb}, \mathrm{Sr}$ and $\mathrm{Nd}$ isotope compositions lie within the range of observed MORB values, but span $\sim 80 \%$ of the Pacific MORB range. The isotope and trace element systematics argue strongly for (at least) two-component mixing involving a normal MORB-source depleted peridotite and a relatively enriched 
material. This enriched material may be characterized by a narrow isotopic range, or it may in turn result from a mixture of components (with different isotope compositions) in roughly constant proportions. A comparison of $\mathrm{Pb}-\mathrm{Sr}-\mathrm{Nd}$ results for seamounts and islands provides some information on the distribution of this enriched material.

The EPR seamount data are roughly correlated on the Sr-Pb (Fig.4.5) and $\mathrm{Nd}-\mathrm{Pb}$ (Fig. 4.6) isotope diagrams. The overall results presumably reflect convective mixing of (several?) mantle components, but the effects are noisy. When other Pacific seamounts (Park et al., in prep.; Lamont, unpublished data) and islands are considered on these plots the data arrays form logical extensions from the enriched end of EPR seamount data, toward both Austral (Tubuaii, St. Helena-type) and Societies (Marquesas, Samoan-type) components. Thus, enriched MORB compositions (similar to seamount alkali basalts) often represent the least radiogenic signatures on seamounts and islands sampled away from ridge axes. Mixing of enriched MORB (rather than depleted MORB) with other components (HIMU, EM 1 and EM 2) may account for much of the observed variability at mid-plate environments. In turn, the EPR seamounts exhibit smaller proportions of the Austral and Societies end-members and Iarger proportions of depleted MORB mantle than do mid-plate seamounts and Pacific islands (Park et al., in prep.). The combined seamount data sets appear to intersect in a cluster at the radiogenic end of the MORB fields on the various isotope diagrams, near the fields for the Mathematicians and EPR seamounts on the $\mathrm{Pb}-\mathrm{Sr}-\mathrm{Nd}$ plots. This suggests that indeed there may be a rough correlation between the extent of enrichment or 
involvement of HIMU, EM 1 and EM 2 components and lithospheric development.

In a general way, the EPR seamount data suggests mixing from depleted MORB mantle (DM) toward a St. Helena-Tubuai i type end-member in $\mathrm{Pb}-\mathrm{Pb}$ space (HIMU). Seamounts sampled away from the East Pacific Rise (Shimada seamount and Mathematicians Ridge) do not display this trend. Following the discussion above, if the variations at these seamounts imply that mixing of different mantle components plays a role there, it involves an E-MORB composition (DM+HIMU?) and EM2. Again, this implies a relationship between sampling (location?) of some components and 1 i thosphere development.

Tatsumoto (1978) and Staudigel et al. (1984) documented $\mathrm{Pb}$ isotope trends along two tectonic lineaments at the island of Hawaij and Loini seamount. The volcanoes which lie on similarly magnetized crust or along crustal "isochrons" (Loihi-Mauna Kea, and Mauna Loa-Kohala) have similar ${ }^{206} \mathrm{~Pb} /{ }^{204} \mathrm{~Pb}$ and ${ }^{207} \mathrm{~Pb} /{ }^{204} \mathrm{~Pb}$. Both isotope ratios increase with decreasing age of the underlying lithosphere, suggesting some degree of lithospheric involvement (Tatsumoto, 1978; Stille et al., 1986). This age trend is opposite to that observed at East Pacific seamounts (Fig. 4.7 ), indicating that processes giving rise to the age progression in Hawai are different from those operating near the East Pacific Rise today. Staudigel et al. (1984) suggested that Koolau compositions (which have a significant EM 1 component) may represent ancient metasomatized mantle accreted to the lithosphere near the ridge, and that inclusion of this material into an ascending diapir which eventually gives rise to 
erupted lavas decreases in extent away from the ridge. There is no evidence for a significant contribution from EM 1 in the studied region near the East Pacific Rise during the last 5-10 m.y.

No ${ }^{3} \mathrm{He} /{ }^{4} \mathrm{He}$ greater than $8.7 \mathrm{R}_{\mathrm{A}}$ have been measured in any of the samples studied here. Primitive (relatively undegassed) mantle ${ }^{3} \mathrm{He} /{ }^{4} \mathrm{He}$ values are probably above $32 \mathrm{R}_{\mathrm{A}}$ (Kurz et al., 1983; Rison and Craig, 1983). The He results at seamounts in the East Pacific thus obviate the need for deep mantle plumes beneath the numerous small seamounts scattered around the world's ocean basins. The small size of these seamounts and their isotopic relationship to major intraplate seamount groups and islands (Fig. 4.3-4.5) suggest that the nature and magnitude of the heterogeneity sampled by the small seamounts may be fundamentally different from that required to explain variations between major "hotspot" volcano provinces. The chemical variations at these small seamounts, ranging from MOR tholeites to alkali basalts more typical of hotspots, likely represent differences in the way melting processes sample the mantle rather than variations in bulk mantle chemistry.

\subsection{Implications for Magmatic Plumbing}

${ }^{3} \mathrm{He} /{ }^{4} \mathrm{He}$ is shown vs. volcano volume in Fig. 4.16. Systematic trends are not apparent in either alkali basalts or tholejies on this diagram, but seamount 7 tholeites and transitional basalts do show lower ${ }^{3} \mathrm{He} /{ }^{4} \mathrm{He}$ than similar lava types at other, much smaller volcanoes. The seamount 7 samples with $10 \mathrm{w}{ }^{3} \mathrm{He} /{ }^{4} \mathrm{He}$ (near $4.0 \mathrm{R}_{\mathrm{A}}$ ) al so have the 


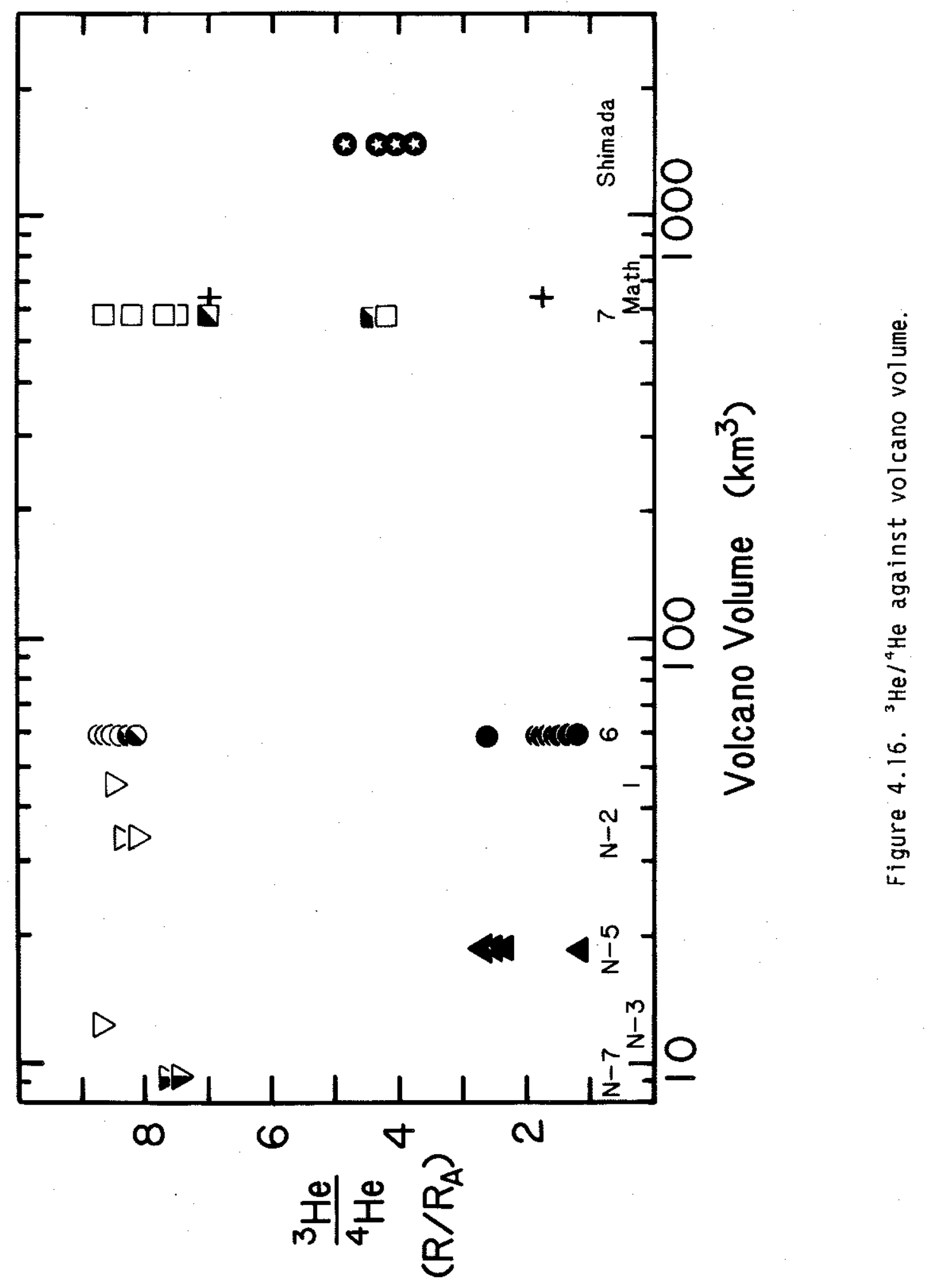


lowest He concentrations for any EPR seamount samples. This suggests that "mining" of He can sometimes occur within the volcanic plumbing system, and that the efficacy of this process may increase at larger volcanoes.

Mixing of tholeijte with an alkalic end-member having low [He] (similar to measured values) requires very high $(>90 \%$ ) proportions of that end-member to generate intermediate He isotopic compositions, inconsistent with other chemical arguments (Batiza and Vanko, 1984; Zindler et al., 1984). The bimodality in the isotope compositions appears best explained by limited mixing of compositionally heterogeneous end-members. Subsequent He loss is most prevalent in alkalic and some transitional magmas erupted at off-axis volcanoes. I infer that these alkalic magmas have lost He and suffered radiogenic He accumulation following mixing. This mixing presumably occurs near the region of melt generation and segregation (Batiza and Vanko, 1984); perhaps magma and/or source mixing triggers He loss in specific cases.

There are three potential processes for generating lower [He] and ${ }^{3} \mathrm{He} /{ }^{4} \mathrm{He}$ in the alkali basalts relative to the tholeiltes; 1 ) isotope fractionation during outgassing, 2) radiogenic ingrowth of ${ }^{4} \mathrm{He}$ following He loss and 3) differences in source composition. The second process has considerable potential for producing the observed variability in ${ }^{3} \mathrm{He} /{ }^{4} \mathrm{He}$. The somewhat systematic $\mathrm{He}-\mathrm{Sr}$ and $\mathrm{He}-\mathrm{Pb}$ relations indeed suggest that the alkali basalt source may have lower ${ }^{3} \mathrm{He} /{ }^{4} \mathrm{He}$, but it is not possible to distinguish this from pre-eruptive radiogenic ingrowth at the present time. 


\subsubsection{Rayleigh Fractionation}

The limit of isotope fractionation due to preferential removal of ${ }^{3}$ He during magma degassing can be estimated with a simple Rayleigh fractionation model. Fig. 4.17 shows ${ }^{3} \mathrm{He} /{ }^{4} \mathrm{He}$ vs. [He]. Assuming no gas loss for the samples with the highest [He], an arbitrary scale for the degree of helium outgassing has been constructed at the top of the diagram. The line shown is the Rayleigh fractionation curve, described by the equation

$$
\ln (R / R)_{0}=(\alpha-1) \ln F
$$

where $R=$ isotopic ratio in the residue, $R_{0}=$ initial ratio, $F=$ fraction of vapor remaining and $\alpha$ is assumed to be $\sqrt{4 / 3}$. No radiogenic production of ${ }^{9} \mathrm{He}$ is assumed in this model, along with removal of ${ }^{3} \mathrm{He}$ and ${ }^{4} \mathrm{He}$ being first order, with steady-state $[\mathrm{He}]=0$ for large times (Craig and Lupton, 1976). Because the alkali basalts fall near this curve it is not possible to eliminate this hypothesis as a possible cause for He isotope differences. However, three lines of evidence argue strongly against this mechanism. Firstly, seamount tholeijtes and most transitional basalts display little He isotope variation even though their He concentrations vary by a factor up to $10^{4}$. Secondly, the alkali basalts at these seamounts, like those from other tectonic settings, contain higher volatile inventories than associated tholeiites (primarily $\mathrm{H}_{2} \mathrm{O} ; \mathrm{Dr}$. D. Muenow, pers. comm.). Therefore their low He contents reflect other processes in addition to volatile loss from magmas with initial concentrations similar to the tholeites. Thirdly, no significant degree of disequilibrium between 
Figure $4.17{ }^{3} \mathrm{He} /{ }^{4} \mathrm{He}$ vs. [He]. The dashed line is the 1 imit for fractionating ${ }^{3} \mathrm{He} /{ }^{4} \mathrm{He}$ by Rayleigh degassing, assuming fractionation is proportional to $\sqrt{4 / 3}$. An arbitrary scale for the fraction of He degassed $(\%)$ is shown along the top assuming no degassing for the highest measured [He] in MORB $\left(\sim 3.0 \times 10^{-5} \mathrm{CCSTP} / \mathrm{g}\right)$. Right hand scale shows the change in ${ }^{3} \mathrm{He} /{ }^{4} \mathrm{He}$ relative to an initial ratio of $8.4 R_{A}$. Time contours $(y)$ are shown for a model of non-fractionating, single stage He degassing followed by closed system radiogenic ingrowth, for $[U]=1 \mathrm{ppm}$ and $T h / U=3$. These contours show the corresponding ${ }^{3} \mathrm{He} /{ }^{4} \mathrm{He}$ a sample would have for its measured magmatic [He]; times for lower [U] will be proportionally longer. For transitional and alkali basalts where isotope disequilibrium between vesicles and glass was measured, points are plotted at the measured vesicle [He], and the arrows terminate at the inherited [He] (estimated to reflect the magmatic value upon eruption as outlined in Fig. 4.10). 


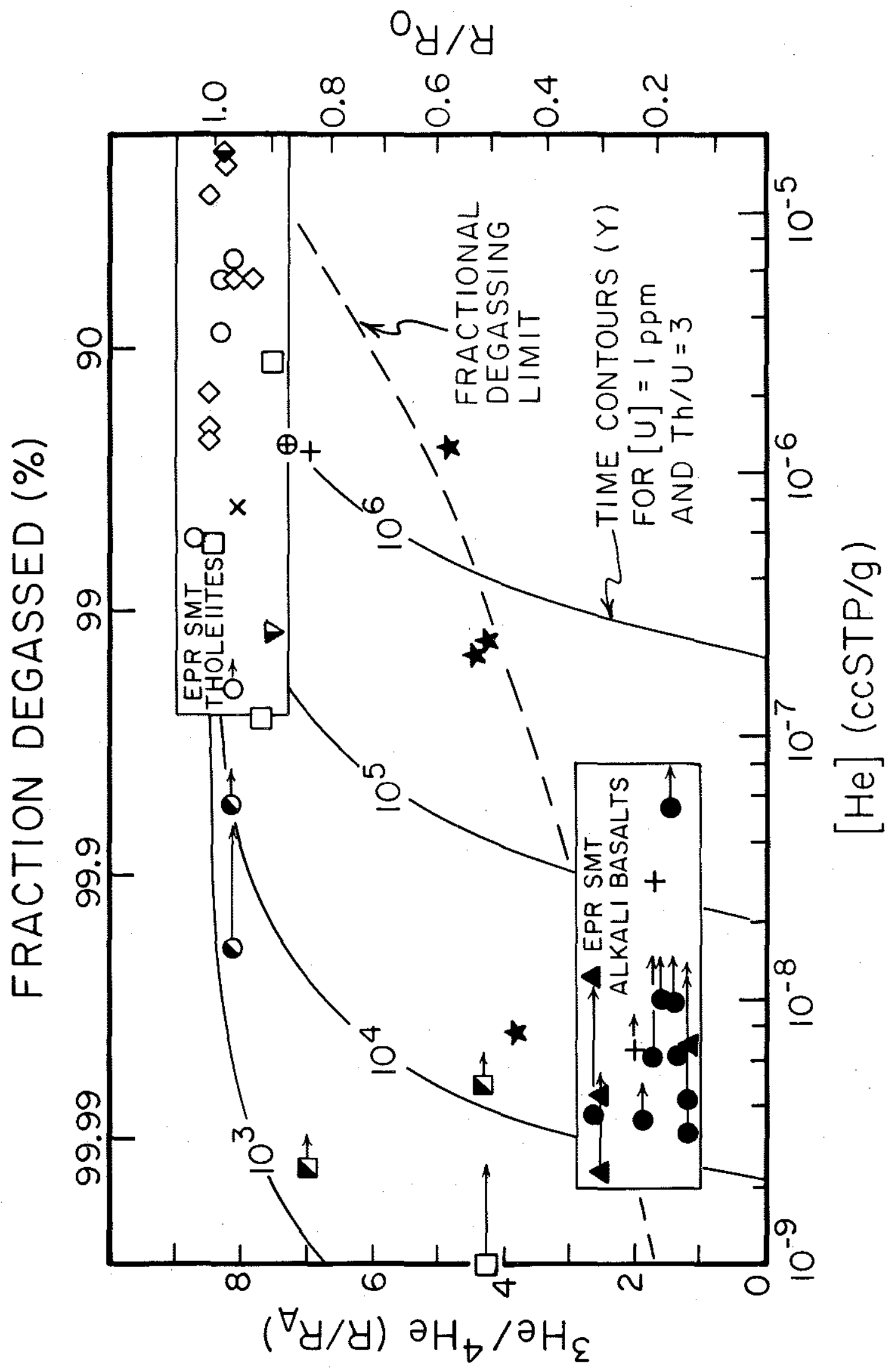


vesicles and glass has been found in extensive studies of ${ }^{3} \mathrm{He} /{ }^{4} \mathrm{He}$ on "zero-age" glasses of widely different [He] (Kurz, 1982; Kurz and Jenkins, 1981; Kurz et $21 ., 1982 \mathrm{~b}$, and the Siqueiros Fracture Zone alkali basalt analyzed in this work), as would be expected by the isotope fractionation model. I conclude that he isotope fractionation during outgassing is not significant for producing the observed ${ }^{3} \mathrm{He} /{ }^{a} \mathrm{He}$ differences.

\subsubsection{Radiogenic Ingrowth Following He LosS}

Given the low He concentrations observed, lowering of ${ }^{3} \mathrm{He} /{ }^{4} \mathrm{He}$ may occur by radiogenic ingrowth of ${ }^{4} \mathrm{He}$ in transitional and alkali basalt magmas, following pre-eruptive stripping of He by other volatiles. The alkalic lavas have $U$ contents up to $1.5 \mathrm{ppm}$ (average $T h / U=3.2$ ) while the tholeites have much lower [U], typically less than 0.1 ppm (Batiza and Vanko, 1984). Fig. 4.17 shows the effect of radiogenic ingrowth on ${ }^{3} \mathrm{He} /{ }^{4} \mathrm{He}$ as a function of magmatic [He], assuming initial ${ }^{3} \mathrm{He} /{ }^{4} \mathrm{He}$ $=8.4 R_{A}$. Curves shown are contours for magma "residence time" since He outgassing, modelled assuming single-stage He loss, $[U]=1 \mathrm{ppm}$ and $T h / U=3$. (If lower $U$ contents apply, times are correspondingly longer). This model calculation suggests that if pre-eruptive stripping of He occurs, the low ${ }^{3} \mathrm{He} /{ }^{4} \mathrm{He}$ in transitional and alkali basalts could be produced on time scales of $10^{4}$ to $10^{5} \mathrm{y}$. I have inferred that the low ${ }^{3} \mathrm{He} /{ }^{4} \mathrm{He}$ trapped in vesicles of the alkali basalts from the EPR seamounts represents the magmatic value because relatively uniform ratios were measured in samples of different age and total [He], and because inherited ${ }^{3} \mathrm{He}$ lies near the MORB partitioning curve (Fig. 3.4). As 
shown in Fig. 4.17, the potential of radiogenic ingrowth for modifying ${ }^{3} \mathrm{He} /{ }^{4} \mathrm{He}$ during magma transport and storage is large. It is not possible to unequivocally demonstrate that the ${ }^{3} \mathrm{He} /{ }^{4} \mathrm{He}$ in alkali basalts erupted at the EPR seamounts represents a source signature. If radiogenic ingrowth in the magma has occurred, the required time is on the order of $10^{4} \mathrm{y}$, consistent with Th-U isotopic disequilibrium studies of MORB and OIB (Allègre and Condomines, 1982; Newman et al., 1983; McKenzie, 1985). Times of this order are too slow to be associated with transport by magma fracture through the lithosphere (Shaw, 1980; Spera, 1981) and with residence in small crustal magma chambers. Rather, the magma "ages" might reflect the time scale for transport by magma migration in the underlying mantle. For melt migration rates on the order of $\sim 1 \mathrm{~m} / \mathrm{y}$ (Watson, 1982), these alkalic magmas would be generated only $10 \mathrm{~km}$ beneath the base of the lithosphere $(\sim 25 \mathrm{~km}$ for $3 \mathrm{~m} . \mathrm{y}$. old lithosphere), i.e. near $12 \mathrm{~kb}$. This is consistent with their apparent generation near the the plagioclase-spinel transition region (Batiza and Vanko, 1984).

The greater than hundred-fold difference in [He] at Shimada seamount and correspondingly small variation $(\sim 20 \%)$ in ${ }^{3} \mathrm{He} /{ }^{4} \mathrm{He}$ suggests very small magma age differences for these samples. The measured [He] in Shimada 03-1 requires an aging time greater than $5 \mathrm{~m} . \mathrm{y}$. by the ingrowth model outlined above (Fig. 4.17), unreasonably long to be attributed to volcanic plumbing effects alone. Of course the true ${ }^{3} \mathrm{He} /{ }^{4} \mathrm{He}$ of the Shimada source depends upon the extent to which the measured values reflect mixing, for example between an enriched (high $\left.\left(U_{+} T h\right) / H e\right)$ end-member and a MORB component. 
Below I present a model for the evolution of ${ }^{3} \mathrm{He} /{ }^{4} \mathrm{He}$ in alkali basalts at seamount 6 , as these results are the most comprehensive and systematic. ${ }^{3} \mathrm{He} /{ }^{4} \mathrm{He}$ of the more evolved alkali basalts $(1.2-1.8$ $R_{A}$ ) is assumed to be an indicator of the magmatic value, allowing the effective volcanic plumbing times for eruption to be computed from the differences in ${ }^{3} \mathrm{He} /{ }^{4} \mathrm{He}$ relative to that of the most primitive alkali basalt ( $A L V 1810 ;{ }^{3} \mathrm{He} /{ }^{4} \mathrm{He}=2.5 \mathrm{R}_{\mathrm{A}}$ ). The "plumbing time" is given by

$$
T=3.6 \times 10^{10}\left\{{ }^{4} \mathrm{He}^{*} /(4.4 \mathrm{U}+\mathrm{Th})\right\} \quad\left(10^{3} \mathrm{y}\right)
$$

where ${ }^{4} \mathrm{He}^{*}=$ amount of radiogenic ${ }^{4} \mathrm{He}$ added to an alkalic magma (with initial ${ }^{3} \mathrm{He} /{ }^{4} \mathrm{He}=2.5 \mathrm{R}_{\mathrm{A}}$ ) which lowers the ${ }^{3} \mathrm{He} /{ }^{4} \mathrm{He}$ by the requisite amount and satisfies the mass balance for ${ }^{3} \mathrm{He}$ and ${ }^{4} \mathrm{He}$ (see eq. 3.2). I assume all ${ }^{3} \mathrm{He}$ is inherited and no gas is lost at eruption; the residence times calculated are therefore minima. ${ }^{4} \mathrm{He}^{*}$ $=\left[{ }^{3} \mathrm{He}\right]\left\{1 /\left({ }^{3} \mathrm{He} /{ }^{4} \mathrm{He}\right)_{V}-1 / 2.5\left(\mathrm{R}_{\mathrm{A}}\right)\right\}$. A striking result of this model is that Mg\# shows an exponential decrease with increasing magma age (Fig. 4.18). Shown in Fig. 4.18 are curves for the evolutionary histories of spherical magma bodies. These curves were constructed for spheres of various sizes with different temperature contrasts between magma and wallrock. Mg\# was parameterized as a function of temperature ( $T$ ) using experimental data from Grove and Bryan (1983); $\left(\mathrm{Mg \#}=0.178 \mathrm{~T}-149.4, \mathrm{~T}\right.$ in $\left.{ }^{\circ} \mathrm{C}\right)$. The average temperature of a magma sphere $(T(t))$ is calculated from

$$
\left(T(t)-T_{\text {out }}\right) /\left(T^{0}-T_{\text {out }}\right)=\left(6 / \pi^{2}\right) \sum\left(1 / n^{2}\right) \exp \left(-n^{2} \pi^{2} K t / r^{2}\right)
$$

where $T^{0}=$ initial melt $T, T_{\text {out }}=$ wall rock $T, K=$ thermal conductivity $\left(2.5 \times 10^{-3} \mathrm{cal} /{ }^{\circ} \mathrm{C}-\mathrm{cm}-\mathrm{sec}\right), r=$ radius $(\mathrm{km})$ and $\mathrm{t}=$ time (Jost, 1952). 
Figure 4.18 Mg\# vs. "magma residence time" for seamount 6 alkali basalts according to the model presented in the text. Numbers next to cooling curves are spherical magma body diameters $(\mathrm{km})$ and magma-wallrock temperature contrasts $\left({ }^{\circ} \mathrm{C}\right)$. Also shown are 10 error estimates in residence time calculated by propogating analytical uncertainties through eq. 4.2 . 


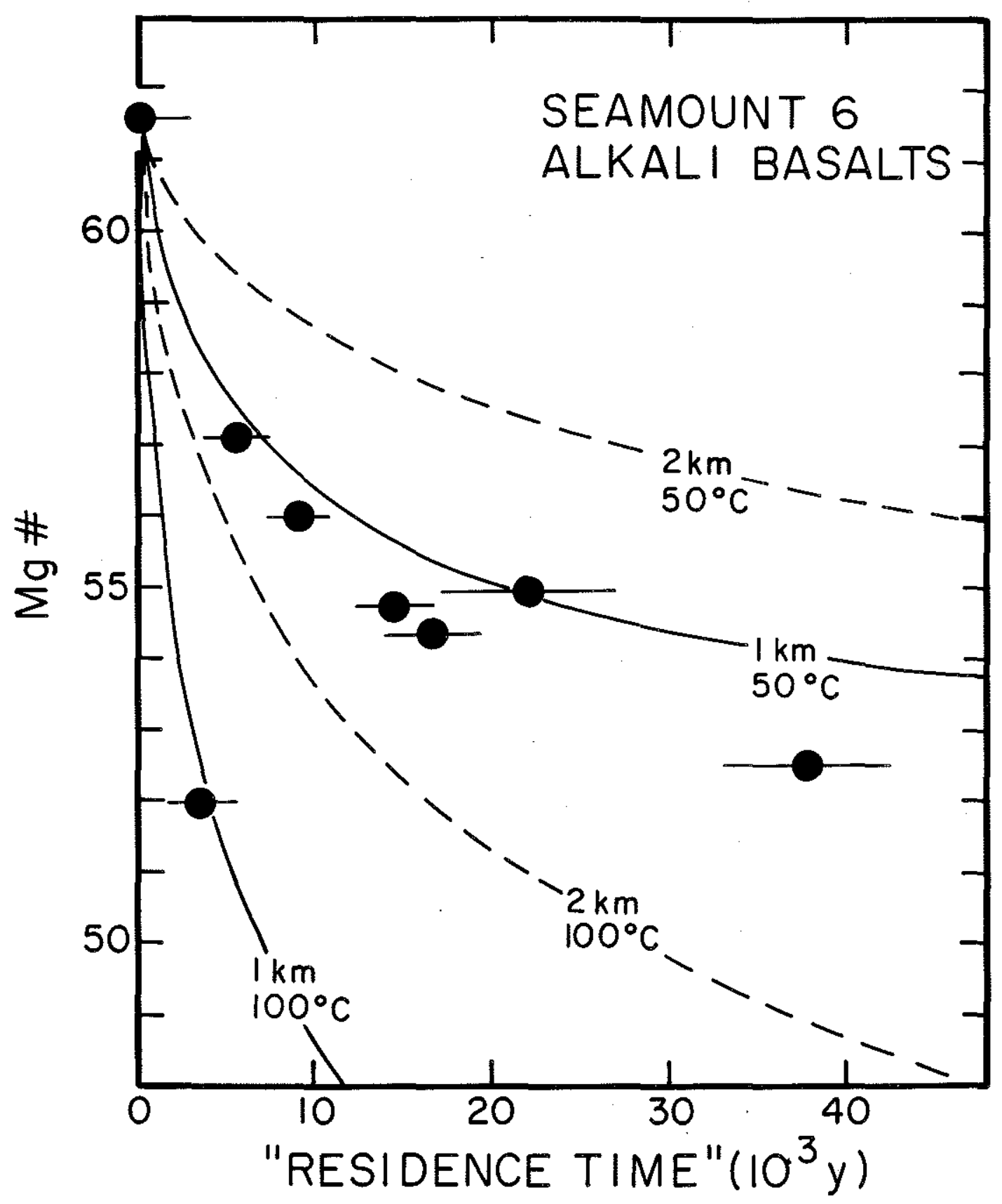


Density of magma $(\rho)$ and wallrock are taken to be $2.7 \mathrm{~g} / \mathrm{cm}^{3}$ and specific heat $\mathrm{c}=0.36 \mathrm{cal} / \mathrm{g}-{ }^{\circ} \mathrm{C}$. The effects of the latent heat of fusion $(L=110 \mathrm{cal} / \mathrm{g}$ ) are included by modifying $k$ iteratively (thermal diffusivity, $k_{i+1}=K_{i} / \rho c^{\prime} ; c^{\prime}=c+L /\left(T^{0}-T(t)\right)$; Jaeger, 1957). In general the alkali basalt lavas at seamount 6 with lower Mg\# exhibit longer "plumbing" times, supporting the pre-eruptive ingrowth hypothesis. For reasonably sized magma bodies $(\mathrm{km})$, this simple model requires that small magma-wall rock temperature contrasts $\left(<100^{\circ} \mathrm{C}\right)$ be maintained for long time periods $\left(\sim 10^{4} y\right)$. If such processes obtain at the EPR seamounts, this simple model suggests that they probably occur deeper than in crustal magma chambers, so that less substantial pre-heating of surrounding wall rock is required.

Another means to investigate the length scale required for lowering the ${ }^{3} \mathrm{He} /{ }^{4} \mathrm{He}$ of a magma batch is a continuous diffusive loss model from a sphere, with coupled radiogenic ingrowth. This model has been presented previously by Hart and Zindler (1987). The assumptions are 1) a spherical magma body with in situ ${ }^{4} \mathrm{He}$ production loses both initial and radiogenic He by diffusive loss, 2) the concentration of He at the boundary $=0,3$ ) there is no radiogenic production of ${ }^{3} \mathrm{He}$, 4) the magma body is non-convecting and 5) equal diffusion coefficients for ${ }^{3} \mathrm{He}$ and ${ }^{4} \mathrm{He}$ apply. The governing equation is

$$
\partial \mathrm{He} / \partial \mathrm{t}=\mathrm{D}\left\{\partial^{2} \mathrm{He} / \partial \mathrm{r}^{2}+(2 / r) \partial \mathrm{He} / \partial r\right\}+\lambda_{8}^{238} \mathrm{U}_{0} \mathrm{e}^{-\lambda_{8}}{ }^{\mathrm{t}}
$$

for the coupled production from ${ }^{238} \mathrm{U}$ and diffusive loss. Similar equations apply for ${ }^{235} \mathrm{U}$ and ${ }^{232} \mathrm{Th}$. The solution (given by Hart and Zindler, 1987; modified from Tilton, 1960) is 


$$
\left({ }^{4} H e /{ }^{238} U\right)_{P}=\left(6 P_{8} / \pi^{2}\right) \sum\left\{\lambda\left[e^{\left(\lambda-n^{2} B\right) t}-1\right] / n^{2}\left(\lambda-n^{2} B\right)\right\}=
$$

$$
\{P D S, 235\}=\left(6 P_{5} / 137.8 \pi^{2}\right) \sum\left\{\lambda\left[e^{\left(\lambda-n^{2} B\right) t}-1\right] / n^{2}\left(\lambda-n^{2} B\right)\right\} .
$$

$$
\{P D S, 232\}=\kappa\left(6 P_{2} / \pi^{2}\right) \sum\left\{\lambda\left[e^{\left(\lambda-n^{2} B\right) t}-1\right] / n^{2}\left(\lambda-n^{2} B\right)\right\},
$$

where $P=$ number of ${ }^{4} \mathrm{He}$ atoms produced per decay of ${ }^{238} \mathrm{U}(8),{ }^{235} \mathrm{U}$ (7) and ${ }^{232} \mathrm{Th}(6)$, respectively, $\lambda$ is the respective decay constant, $r$ is the magma body radius, and $B=\pi^{2} D / r^{2}$. The value for $D$ was extrapolated from data for basaltic glass (Kurz and Jenkins, 1981) to $1200^{\circ} \mathrm{C}$, giving $D_{H e}=7.5 \times 10^{-5} \mathrm{~cm}^{2} / \mathrm{sec}$. (Note that this value is approximately three times larger than recently determined experimentally for a tholeiitic basalt melt at the same temperature; Lux, 1987). The diffusive loss of initial ${ }^{3} \mathrm{He}$ and ${ }^{4} \mathrm{He}$ have no production terms and thus are

$$
\begin{aligned}
& \left({ }^{3} \mathrm{He}_{\mathrm{P}} /{ }^{3} \mathrm{He} \mathrm{e}_{0}\right)=\left({ }^{4} \mathrm{He}_{\mathrm{P}} /{ }^{4} \mathrm{He} \mathrm{e}_{0}\right)=\left(6 / \pi^{2}\right) \sum\left\{\mathrm{e}^{-n^{2} \mathrm{Bt}} / \mathrm{n}^{2}\right\}=\{\mathrm{DS}\} \\
& \left({ }^{4} \mathrm{He} /{ }^{3} \mathrm{He}\right)_{\mathrm{P}}=\left({ }^{4} \mathrm{He} /{ }^{3} \mathrm{He}\right)_{0}+ \\
& \left({ }^{2{ }^{3}} \mathrm{U} /{ }^{3} \mathrm{He}\right)_{0}[\{\mathrm{PDS}, 238\}+\{\mathrm{PDS}, 235\}+\{\mathrm{PDS}, 232\}] /\{\mathrm{DS}\}
\end{aligned}
$$

For He loss greater than $85 \%$, and for $r$ less than $3 \mathrm{~km}$ (i.e., $\lambda<<$ ) \{DS\} and \{PDS\} converge with 3 terms. The results of this model for two different size magma batches, 1 and $0.2 \mathrm{~km}$ diameter are shown as a function of time in Fig. 4.19 and 4.20. The specified initial conditions are arbitrary but reasonable, and are only chosen to illustrate the effects. The lowering of ${ }^{3} \mathrm{He} /{ }^{4} \mathrm{He}$ applicable to the present work, for timescales on the order of $10^{4} \mathrm{y}$, requires magma diameters on the order of hundreds of meters. For the $0.2 \mathrm{~km}$ case (Fig. 4.20), steady-state is reached after about $43 \times 10^{3} \mathrm{y}$, at which time 
Figure 4.19 Continuous diffusive loss model of Hart and Zindler (1987) for a $1 \mathrm{~km}$ diameter magma chamber with the following initial conditions; ${ }^{3} \mathrm{He} /{ }^{4} \mathrm{He}=8.4 \mathrm{R}_{\mathrm{A}},[\mathrm{He}]=5 \times 10^{-7}$ $\operatorname{cCSTP} / \mathrm{g},[U]=0.5 \mathrm{ppm}$ and $T h / U=3$. The diffusion coefficient for He at $1200^{\circ} \mathrm{C}$ was taken to be $7.5 \times 10^{-5} \mathrm{~cm}^{2} / \mathrm{sec}$, extrapolated from data in Kurz and Jenkins (1981). No radiogenic production of ${ }^{3} \mathrm{He}$ is assumed. Steady-state, where loss by diffusion equals production by radioactive decay, is reached for the case shown in $\sim 950 \times 10^{3} y$. 


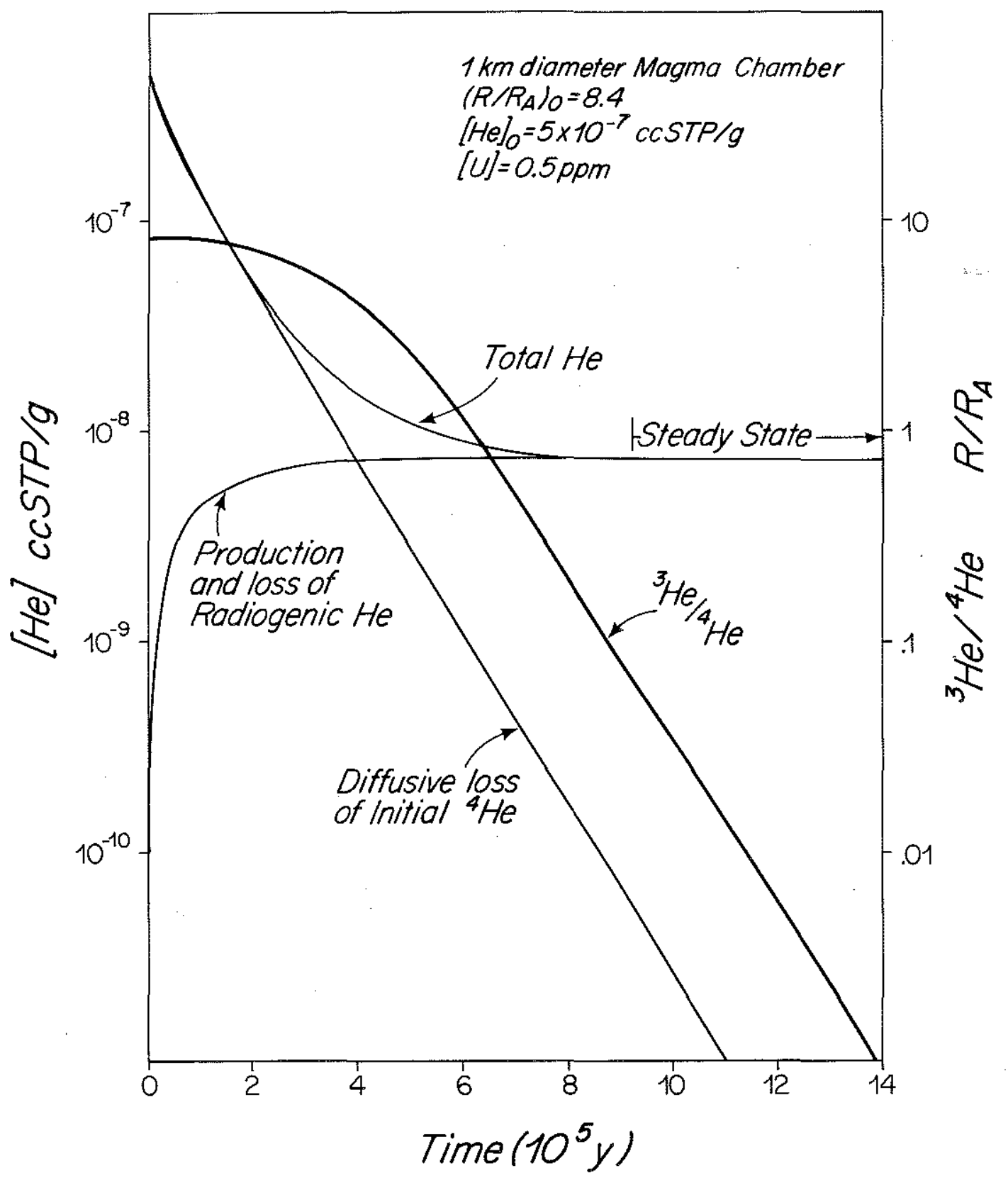


Figure 4.20 Continuous diffusive loss model for a $0.2 \mathrm{~km}$ magma body with the same conditions as specified for Fig. 4.19. Steady-state is reached for this case in $\sim 43 \times 10^{3} \mathrm{y}$. 


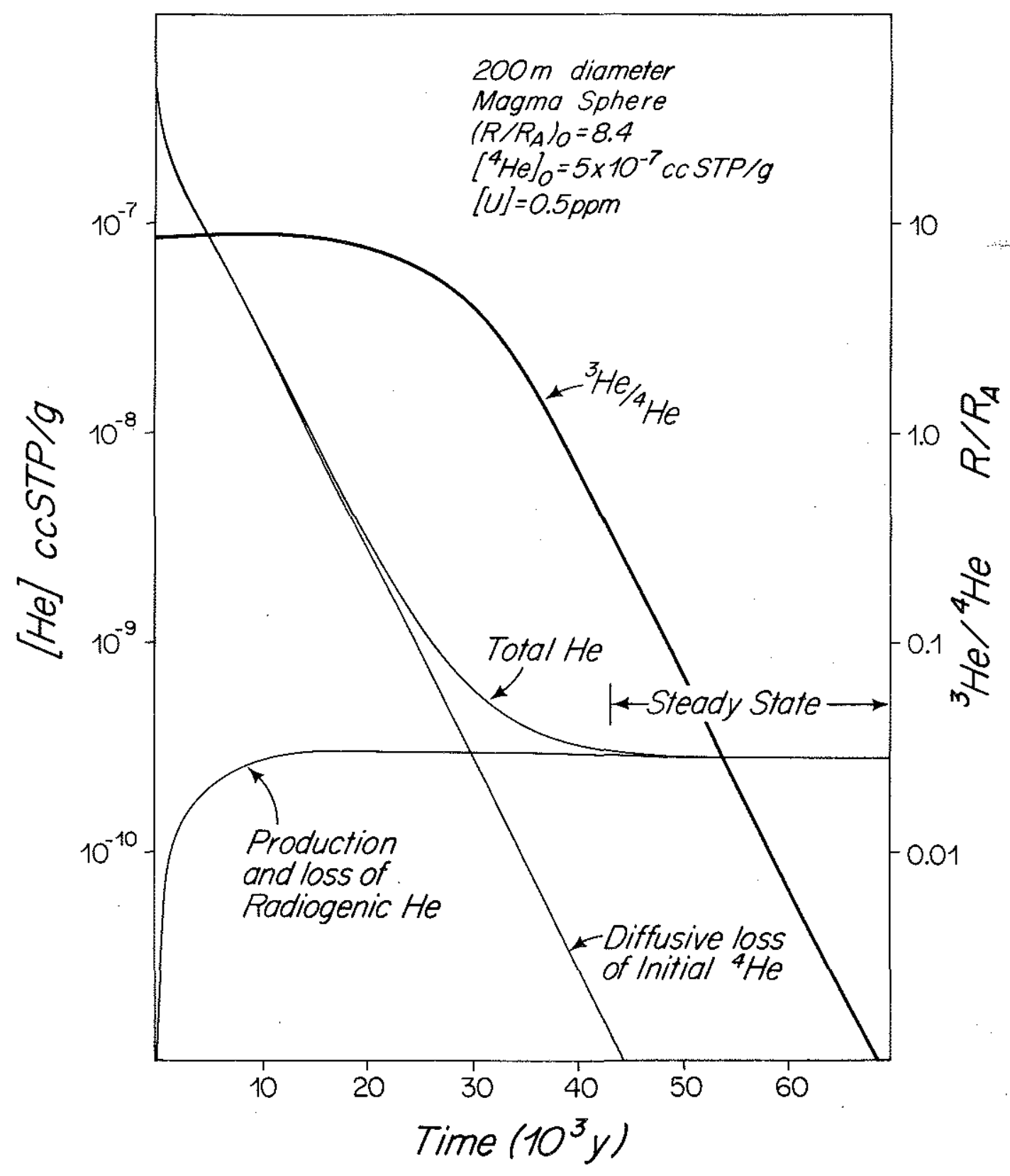


diffusive loss balances radiogenic production. Larger sizes require progressively longer times to achieve steady-state. (For example, a $1 \mathrm{~km}$ diameter body requires $\left.\sim 10^{6} \mathrm{y}.\right)$ The lowering of ${ }^{3} \mathrm{He} /{ }^{4} \mathrm{He}$ is not a strong function of the initial U/He ratio, for inherited [He] less than about $5 \times 10^{-6} \mathrm{CCSTP} / \mathrm{g}$ (Fig 4.21). At higher inherited [He] the model will not work for typical $U$ contents and any reasonable size volume of magma, because not enough He can be lost by diffusion.

For a cooling sphere of magma that loses heat only by conduction, the maximum permissible temperature contrast between magma and wallrock can be estimated as a boundary condition prior to complete solidification of the sphere. Following Hart and Zindler (1987) this is given by

$$
V / A=\left[\left(T_{m}-T_{0}\right) / \rho_{s} L\right]\left[(2 / \sqrt{\pi})\left(\sqrt{K_{m} \rho_{m} C_{m} t_{f}}\right)+K_{m} t_{f} / r\right)
$$

where $V=s p h e r e$ volume, $A=s u r f a c e$ area, $m$ and $s$ are melt and solidified melt (wall rock), $K=$ thermal conductivity, $c=$ specific heat, $t_{f}=$ total solidification time and $L$, the latent heat of fusion, is taken as 110 $\mathrm{cal} / \mathrm{g}+0.36\left(100^{\circ} \mathrm{C}\right)=146 \mathrm{cal} / \mathrm{g}, . \mathrm{Fig} .4 .22$ shows the calculated temperature contrast as a function of time for magma bodies of various size. Contours are also shown for the cases of lowering ${ }^{3} \mathrm{He} /{ }^{4} \mathrm{He}$ (from an initial ratio of $8.4 R_{A}$ ) by $10 \%$ and $90 \%$, respectively, that occur for each initial U/He ratio in a given batch. For the problem of interest here, a $1 \mathrm{~km}$ diameter batch must maintain a temperature contrast less than $20^{\circ} \mathrm{C}$ for more than $10^{5}$ y to remain molten. The continuous diffusive loss model applied to such a magma body predicts that its ${ }^{3} \mathrm{He} /{ }^{4} \mathrm{He}$ could be lowered by more than $90 \%$ if initial $\mathrm{U} / \mathrm{He}$ $(\mathrm{ppm} / \mathrm{ccSTP} / \mathrm{g})$ is greater than $10^{8}$ (comparabie to seamount alkali basalts). Such small temperature contrasts (similar to those outlined 


\section{Figure $4.21{ }^{3} \mathrm{He} /{ }^{4} \mathrm{He}$ against time for the two cases illustrated in Fig. 4.19 and 4.20. Note the strong dependence on magma body size for the specified conditions, and the weaker dependence on initial U/He (in ppm/cC STP/g).}




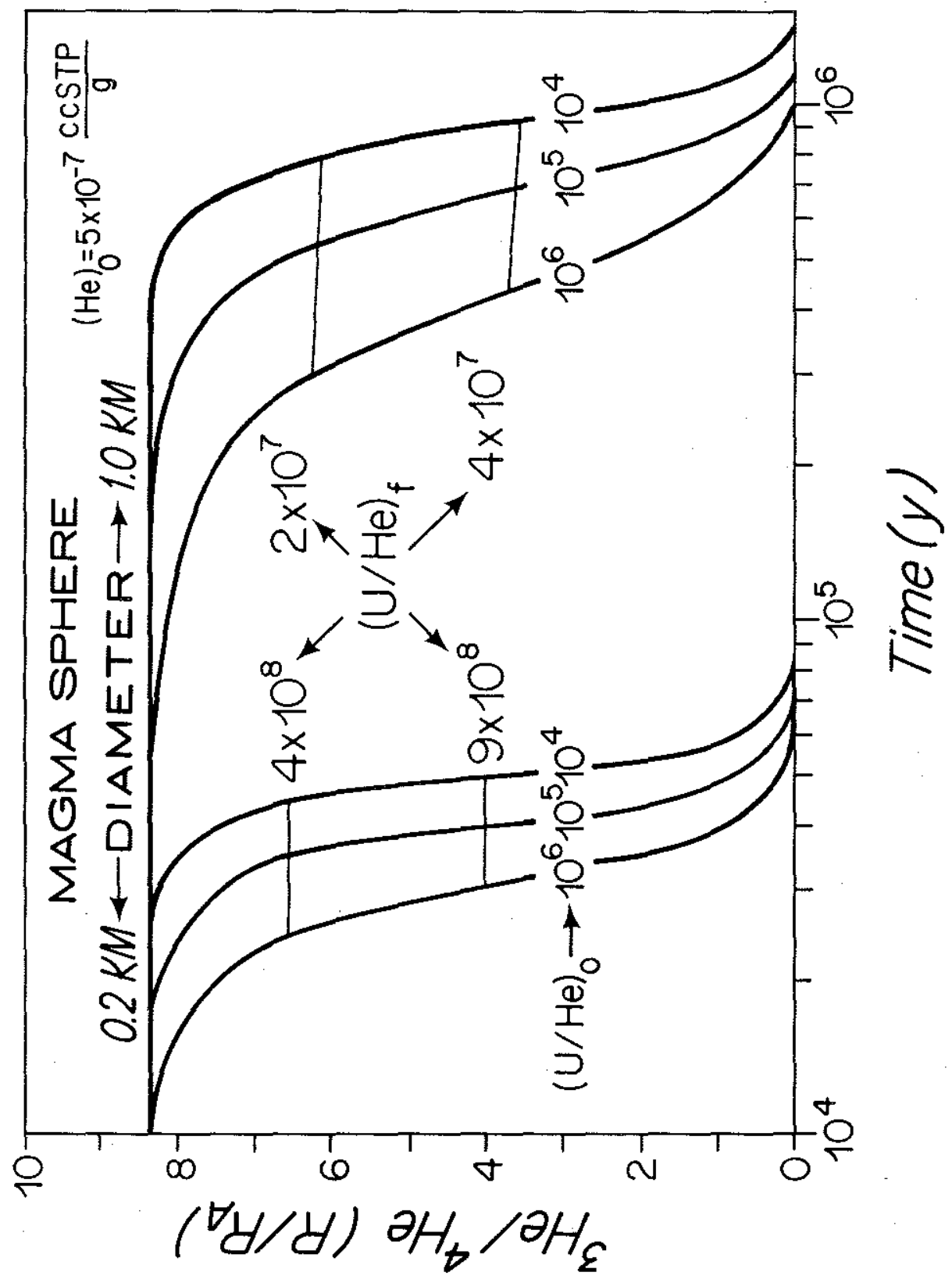


Figure 4.22 Magma sphere cooling model (adapted from the fixed melting point formulation of Flemings, 1968) following Hart and Zindler (1987) (eq. 4.10 in text). $\Delta T$ is the temperature contrast between molten magma and solidified wallrock. Numbers next to curves are initial U/He (in ppm/ccSTP/g). Paired curves are for a $90 \%$ (upper) and 10\% (lower) lowering of initial ${ }^{3} \mathrm{He} /{ }^{4} \mathrm{He}\left(8.4 \mathrm{R}_{\mathrm{A}}\right)$ in the specified time $(y)$. For example, to achieve a $90 \%$ decrease in a $1 \mathrm{~km}$ diameter unreplenished magma body requires an initial $(\mathrm{U} / \mathrm{He})$ of $10^{8}$, and a temperature contrast less than $20^{\circ} \mathrm{C}$ to be maintained for more than $1.8 \times 10^{5} \mathrm{y}$. 


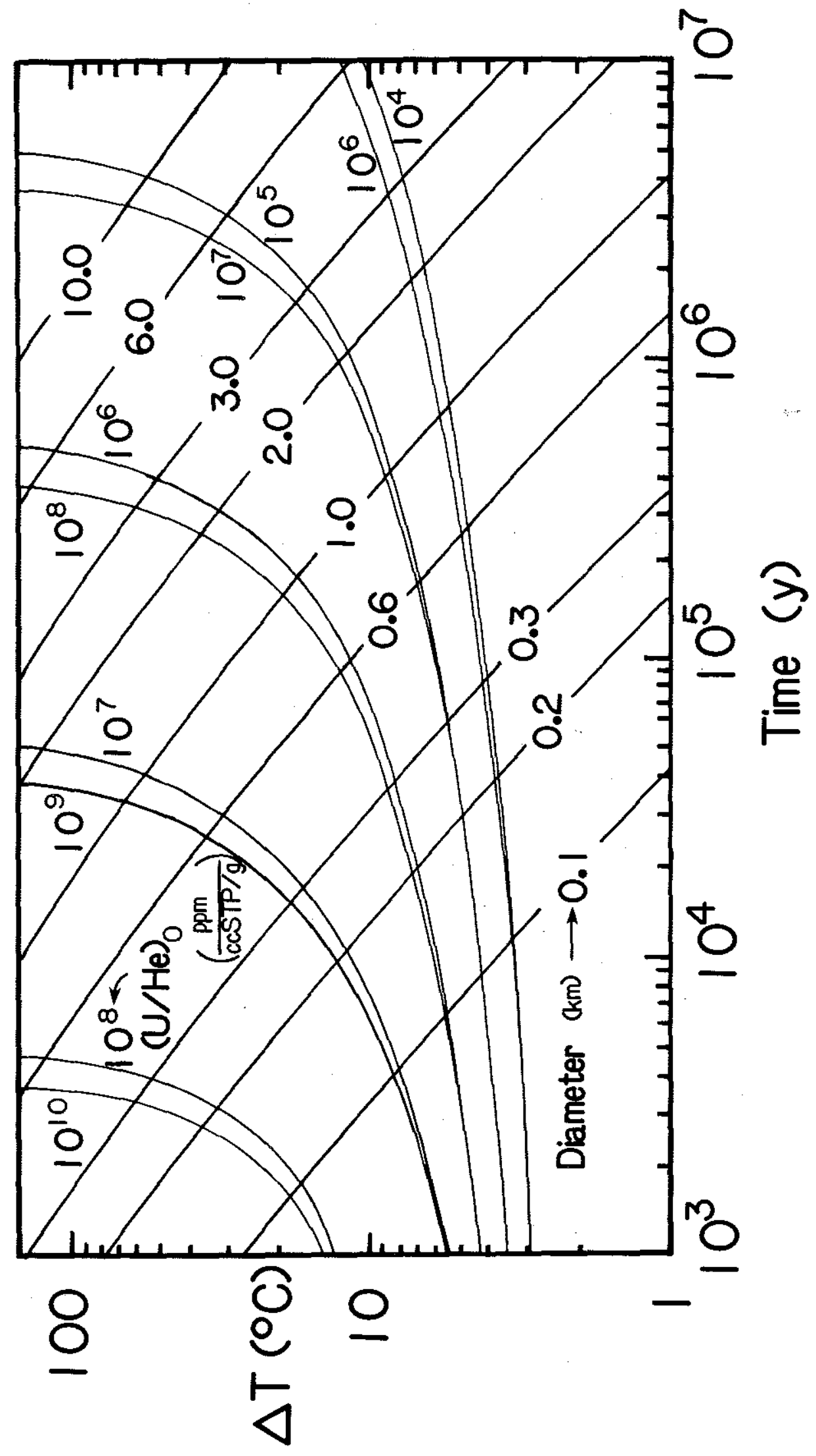


above for the seamount 6 alkali basalts) require a significant preheating of surrounding wallrock. This would be difficult to achieve in a crustal setting cooled by hydrothermal circulation. Thus, if the model is applicable it suggests that magma batches lose nearly all their He deeper in the lithosphere. This model is overly simplistic in that it neglects magma convection, and the movement and changing geometry of magma batches, but it is enlightening as a first approach. If the dynamic effects were included, the effective magma batch size could certainly be larger. In a dynamic model He and heat loss would ultimately reduce to a boundary layer problem in which transport would be dominated by diffusion. Therefore the temperature contrasts required might not be very different than those estimated here.

\subsection{Implications for the Alkali Basalt Source}

Seamount alkali basalts may be generated by discrete batches of magma which segregate from the mantle source region. These batches are small, such that cooling during ascent may be significant. Discrete batches might interact with other, more voluminous tholeitic melts. Given the complexity of the plumbing systems (e.g., cracks in the lithosphere), this interaction should occur predominantly along conduit walls or other boundary layers. This may produce the bimodality in some isotope compositions. Batches generated by smaller degrees of partial melting (leading to more alkalic magmas) may be produced by melting smaller mantle domains; given their smaller size, these batches may lose proportionally more heat and He, thus leading to increased $\left(U_{+} T h\right) / H e$. Crystallization would also be more extensive for smaller batches. 
Seamounts in many cases are related to the loci of fracture zones and transform faults (Batiza and Vanko, 1983). Diverse magma production, of both primitive and evolved types, has also been attributed to transform fault effects along ridge axes (Langmuir and Bender, 1984; Langmuir et al., 1986). In cases where seamounts tap magma from less restricted plumbing systems (e.g., in association with the mid-ocean ridge) the He systematics may partially reflect mixing with voluminous MORB magmas and evolution in larger reservoirs. For example, the $21^{\circ} \mathrm{N}$ seamounts are very close to the ridge axis and possibly connected to its magmatic system. Tholei ites from those seamounts show decreases in [He] accompanying crystal fractionation (Fig. 4.10).

The fundamental observation that $10{ }^{3} \mathrm{He} /{ }^{4} \mathrm{He}$ is associated with low [He] in alkali basalts from the EPR seamounts constrains the separation of $(U+T h)$ from $H e$ to be a recent event $\left(<10^{5} y\right)$. It is possible that alkalic magmas lose proportionately more He upon ascent and eruption, due to higher volatile contents and correspondingly lower viscosities. Vesicularities in the EPR seamount alkali basalts are less than $6 \%$, insufficient to account for the large difference in tholeite and alkali basalt [He] solely by gas loss at eruption. The low [He] may reflect the stripping effect by volatiles prior to eruption. If the low [He] reflects gas loss just prior to eruption, with the low ${ }^{3} \mathrm{He} /{ }^{4} \mathrm{He}$ $\left(2.5 \mathrm{R}_{\mathrm{A}}\right.$ ) in high $\mathrm{Mg}$ \# alkali basalts derived by mixing between a MORB magma and an enriched melt (generated from a source which has remained a closed system with respect to radiogenic He accumulation), a crude estimate of those source characteristics can be made. For a time scale comparable to that inferred from Pb-Sr-Nd sytematics $\left(\sim 10^{8} \mathrm{y}\right)$, the 
enriched end member would have $[\mathrm{He}] \approx 2 \times 10^{-6} \mathrm{CCSTP} / \mathrm{g}$ and ${ }^{3} \mathrm{He} /{ }^{4} \mathrm{He} \approx 0.01 R_{A}$, assuming no initial $\mathrm{He}$. (For $U=1 \mathrm{ppm}$, $T h / U=3$ in the source, the production rate of ${ }^{4} \mathrm{He}$ is $2 \times 10^{-7}$ CC STP/g/m.y.). ${ }^{3} \mathrm{He} /{ }^{4} \mathrm{He}$ would equal $2.5 \mathrm{R}_{\mathrm{A}}$ in alkali basalts derived by mixing approximately $40 \%$ of an alkalic magma generated by $10 \%$ partial melting of this enriched material ( $[\mathrm{He}]_{\operatorname{magma}}=2 \times 10^{-5} \mathrm{cCSTP} / \mathrm{g}$ ) with approximately $60 \%$ of a MORB magma ( $[\mathrm{He}]=3 \times 10^{-5} \mathrm{cCSTP} / \mathrm{g}$ and ${ }^{3} \mathrm{He} /{ }^{4} \mathrm{He}=8.4 \mathrm{R}_{\mathrm{A}}$ ). By this scenario, the low [He] in alkali basalts must be explained by very recent $\left(<10^{3} y\right)$ separation of $\left(U_{+} T h\right)$ from He by gas loss. The Mg\#-plumbing time relationship (Fig. 4.18) must then be considered fortuitous.

\subsection{He-Sr-Pb Isotope Systematics and Magma Genesis}

${ }^{3} \mathrm{He} /{ }^{4} \mathrm{He}$ vs. ${ }^{87} \mathrm{Sr} /{ }^{85} \mathrm{Sr}$ is shown in Fig. 4.23 for some oceanic islands and seamounts. As discussed, tholeittes and alkali basalts from the EPR seamounts do not overlap in isotopic composition, with alkali basalts always having more radiogenic (lower ${ }^{3} \mathrm{He} /{ }^{4} \mathrm{He}$ ) values. $\mathrm{Sr}-\mathrm{Nd}-\mathrm{Pb}$ systematics at Shimada seamount resemble those of Samoan post-erosional lavas (Wright and White, 1987); on the He-Sr diagram Shimada seamount approaches values similar to Tristan da Cunha and Gough Island. Samoan xenoliths have high ${ }^{3} \mathrm{He} /{ }^{4} \mathrm{He}$ (Rison and Craig, 1982; Fig. 4.23). However, as discussed by Wright and White (1987), the xenoliths found in the Samoan post-erosional lavas are probably melting residues of the shield source and are unrelated to the post-erosional source. The Shimada results suggest that the EM 2 component has ${ }^{3} \mathrm{He} /{ }^{4} \mathrm{He}$ less than MORB. Alternatively, the low ${ }^{3} \mathrm{He} /{ }^{4} \mathrm{He}$ suggests 


\section{Figure $4.23 \quad{ }^{3} \mathrm{He} /{ }^{4} \mathrm{He}$ vs. ${ }^{87} \mathrm{Sr} /{ }^{86} \mathrm{Sr}$ for seamount glasses, some oceanic islands and MORB. H=Hualalai, Hawai $i, K=K i l a u e a$, ML=Mauna Loa. Data sources are Kurz et a1. (1982a) and Lupton (1983).}




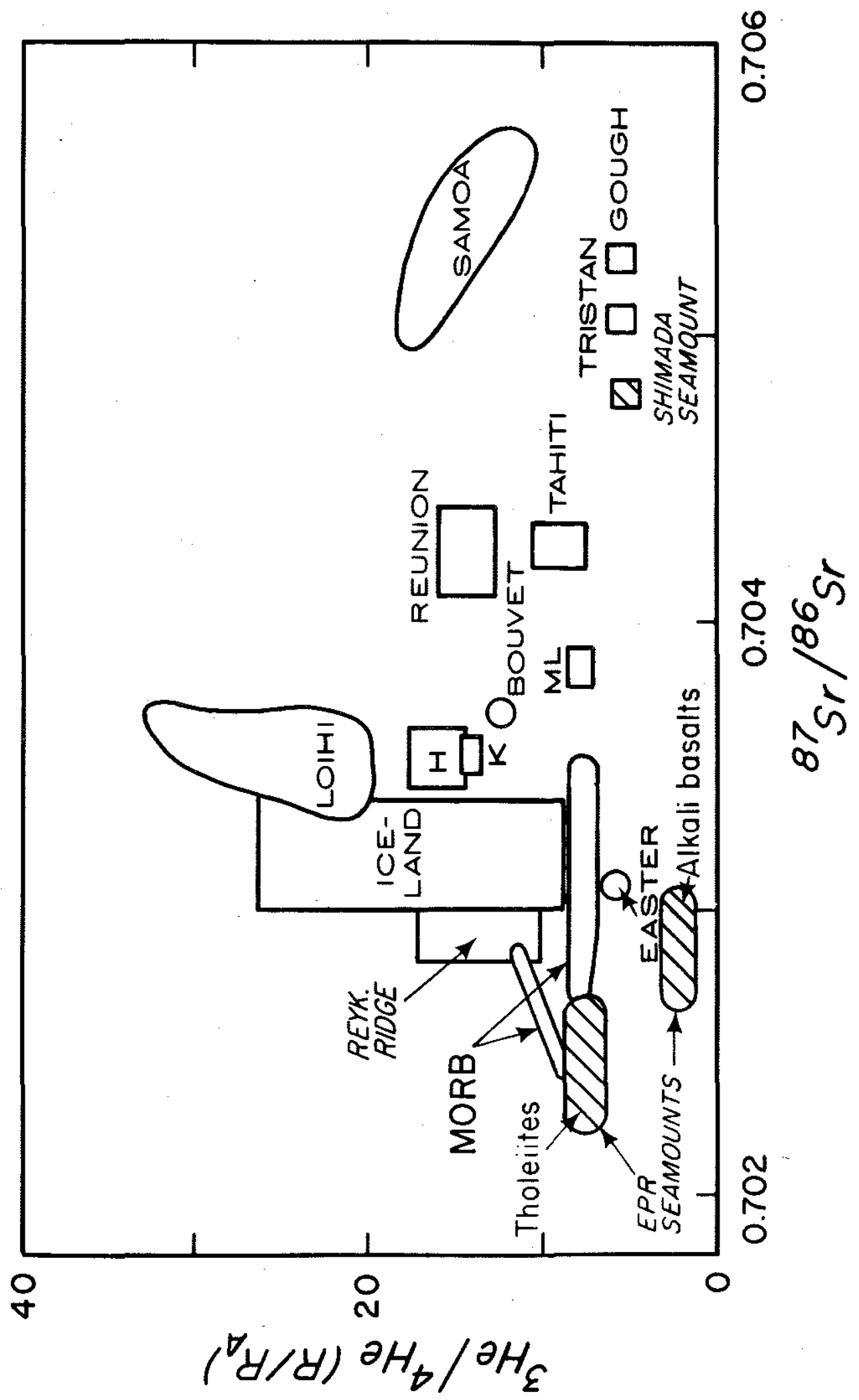


that recent $\left(\sim 10^{7} y\right)$ local generation of high $\left(U_{+} T h\right) /$ He domains may obscure simple relationships between He and other long-lived radiogenic systems. Creation of high $\left(U_{+} T h\right) /$ He domains in the lithosphere during its thickening away from ridge axes, or metasomatism with high $(U+T h) / H e$ fluids in the source region are two mechanisms whereby $\mathrm{He}$ and $\mathrm{Pb}$ isotope variations might become decoupled.

${ }^{3} \mathrm{He} /{ }^{4} \mathrm{He}$ vs. ${ }^{206} \mathrm{~Pb} /{ }^{204} \mathrm{~Pb}$ is shown in Fig. 4.24 for all paired analyses. The "popping rock" from the Mathematicians Ridge (D9) and the two alkali basalts from the East Pacific Rise have ${ }^{3} \mathrm{He} /{ }^{4} \mathrm{He}=7.2-8.0$ $R_{A}$ and intermediate ${ }^{206} \mathrm{~Pb} /{ }^{204} \mathrm{~Pb}(=18.6)$, similar to EPR seamount transitional basalts. These ridge alkali basalts and the seamount transitional basalts appear to partly define a mixing curve between tholeites and seamount alkali basalts. The sample from seamount 7 $(C D-2)$ with low ${ }^{3} \mathrm{He} /{ }^{4} \mathrm{He}$ has very low [He] and likely has suffered radiogenic contamination of the magma. One alkali basalt from the transform seamount on the Mathematicians Ridge (DI) is completely different however, having the most radiogenic $\mathrm{Pb}$ of all samples analyzed $\left({ }^{206} \mathrm{~Pb} /{ }^{204} \mathrm{~Pb}=19.8\right)$, but intermediate ${ }^{3} \mathrm{He} /{ }^{4} \mathrm{He}\left(6.9 \mathrm{R}_{\mathrm{A}}\right)$. ${ }^{3} \mathrm{He} /{ }^{4} \mathrm{He}$ and ${ }^{206} \mathrm{~Pb} /{ }^{204} \mathrm{~Pb}$ results in the East Pacific are not correlated in a simple manner, making it difficult to identify discrete components beneath East Pacific seamounts from the $\mathrm{He}-\mathrm{Pb}$ isotope diagram. The He-Pb characteristics of Math $\mathrm{D}-1$ are intermediate when compared to results for samples from the island of St. Helena and some MORB from the South Atlantic, as discussed in chapter 5.

If ${ }^{3} \mathrm{He} /{ }^{4} \mathrm{He}$ is relatively homogeneous beneath the East Pacific Rise, there are at least three possible mechanisms by which recent 
Figure $4.24{ }^{3} \mathrm{He} /{ }^{4} \mathrm{He}$ vs. ${ }^{206} \mathrm{~Pb} /{ }^{204} \mathrm{~Pb}$ for Pacific seamounts.

Only paired analyses are included. 





separation of $\left(U_{+} T h\right)$ from He might occur. These mechanisms all invoke a process by which different elements derive from different source volumes during magma generation, with more incompatible elements being drawn from a larger mantle volume than that giving rise to the magma itself (O'Hara, 1985). These mechanisms include 1) differential solid/melt partitioning of $\left(U_{+} T h\right)$ relative to $H e$, due to residual trace phases in which $U$ and/or Th are moderately compatible (Galer and O'Nions, 1986); 2) early separation of a fluid phase (McKenzie, 1985b; Galer and O'Nions, 1986) enriched in He relative to $(U+T h)$ prior to more extensive melting at shallower depths; or 3) differential melt/solid migration and magma-wall rock chemical exchange (McKenzie, 1985b; Richter, 1986). ${ }^{3} \mathrm{He} /{ }^{4} \mathrm{He}$ may well be coupled to the isotope systematics of $\mathrm{Pb}, \mathrm{Sr}$ and Nd at depth beneath the ridge, but its signature could be significantly overprinted by such effects during magma genesis.

One intriguing scenario is the following (Fig. 4.25). When isotopically diverse mantle rises, the material directly beneath the ridge axis passes through the zone of maximum melt extraction, while farther away from the axis the degree of melt extraction is less (oxburgh and Turcotte, 1968; Sleep, 1984; O'Hara, 1985; Mckenzie, 1985b). At some distance away from the central axis, a spatial limit of physically separable melt is reached (within the zone of meiting). Material which passes outside this envelope is accreted to the lower lithosphere. If seamounts close to the ridge tap this material during volcanism, their systematic displacement toward MORB isotope compositions could be explained by more extensive melting than at seamounts farther off-axis. For example, smaller volumes may be melted farther from the ridge due to 
Figure 4.25 Cartoon depicting a scenario for separation of $\left(U_{+} T h\right)$ from He in mantle source regions during magma genesis beneath a mid-ocean ridge. 


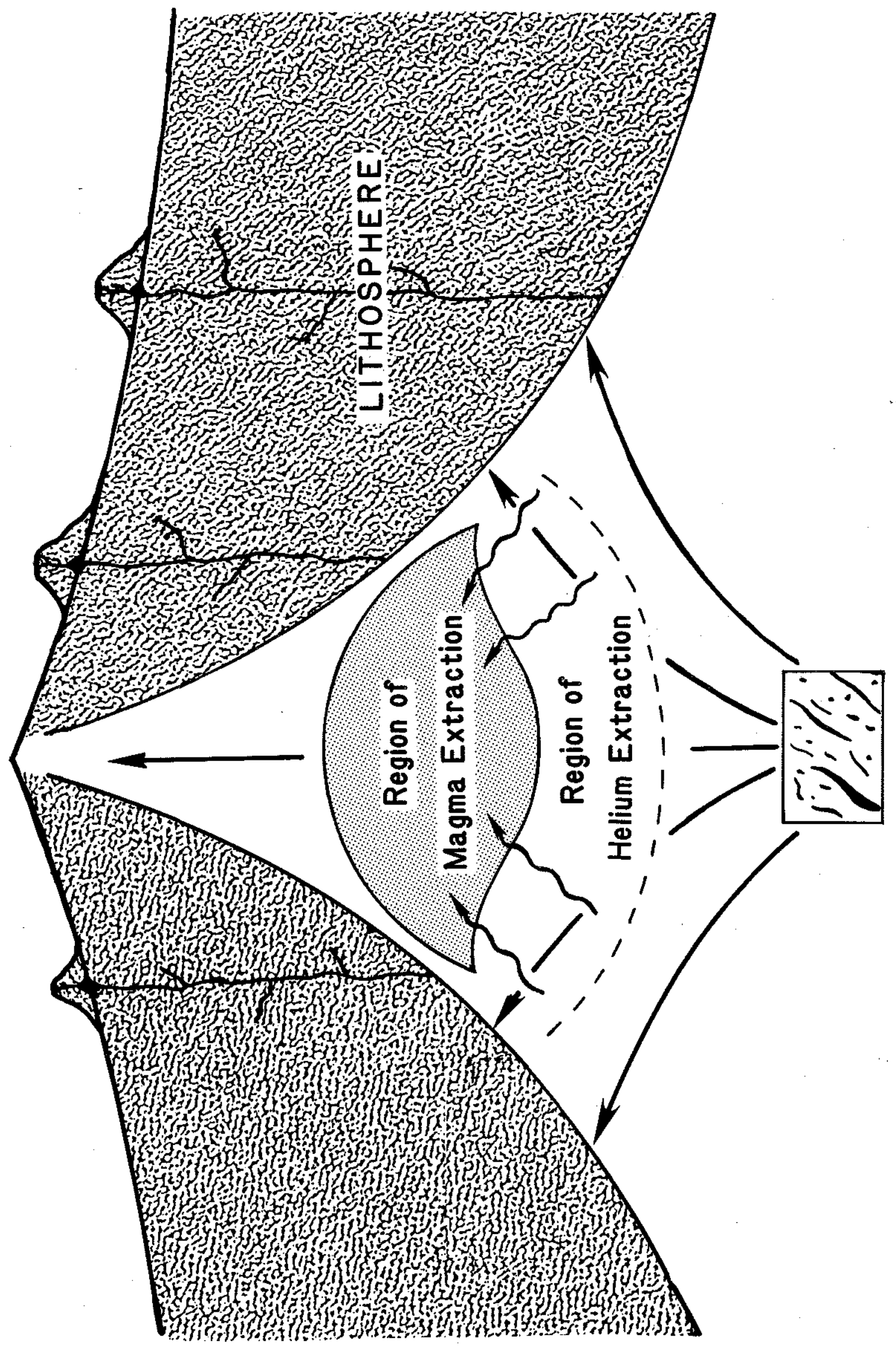


lower heat input. Decreases in the volume of the melting domain are ultimately related to a lower geothermal gradient. Melting associated with ridge volcanism likely produces a non-uniform distribution of heterogeneities in the lower lithosphere. Thus another possibility is that isotopic domains enriched in ${ }^{206} \mathrm{~Pb} /{ }^{204} \mathrm{~Pb},{ }^{87} \mathrm{Sr} /{ }^{86} \mathrm{Sr}$ (and $\left.{ }^{4} \mathrm{He} /{ }^{3} \mathrm{He}\right)$ are more concentrated in lithosphere accreted farther from the ridge, and seamounts closer to the ridge tap shallower material, some of which has passed through the zone of melt extraction and is more depleted. With regard to these points, seamount 6 is located on 3 million year old seafloor, where the lithosphere is $\sim 15 \mathrm{~km}$ thick. If the oceanic crust is generated by $\sim 10-25 \%$ partial melting of the underlying mantle, then to a first approximation lithosphere below the upper $10-25 \%$ of the thickest oceanic 1 ithosphere $(\sim 100 \mathrm{~km})$ will not see significant melt extraction. This might explain why the isotope diversity is so dramatic at seamount 6 ; it represents the onset of tapping of material from lower 1 ithosphere where more enriched material and/or less uniform distribution of heterogeneities becomes predominant.

During transit just outside the melt extraction region some of the enriched domains (which possibly possess a lower solidus and higher volatile content) may undergo He extraction in the absence of significant melt extraction. The region of melt extraction beneath the ridge may thus act as a He sink. When the chemically diverse material is tapped as the source material for alkali basalts at an off-axis seamount, its low ${ }^{3} \mathrm{He} /{ }^{4} \mathrm{He}$ potentially reflects the time since volatile loss. Thus, the origin of low ${ }^{3} \mathrm{He} /{ }^{4} \mathrm{He}$ components sampled at some oceanic islands may arise from processes operating near the ridge axis during lithosphere 
formation.

The inference that He may be enriched in magma source regions has implications for the coupled oceanic fluxes of heat and helium. This inference is highly tentative. The He/heat flux ratio depends on chemical and thermal Peclet numbers (the effective transport distances by diffusion/advection), permeability and degree of elemental partitioning associated with migrating fluids (Bickle and McKenzie, 1987). These parameters are not well constrained for mantle conditions.

\subsection{Summary}

$\mathrm{He}, \mathrm{Pb}, \mathrm{Sr}$ and $\mathrm{Nd}$ isotope systematics of basaltic glasses from young seamounts near the East Pacific Rise are consistent with mixing of compositionally heterogeneous tholeitic and alkalic end-members near the source of magma generation. Tholei ites at these seamounts are isotopically indistinguishable from normal MORB, while alkali basalts always show more radiogenic signatures. Collectively, the isotope results imply that during the early stages of near-axis seamount volcanism, the high input of heat, due to proximity to the ocean ridge, generates tholeitic magma derived largely from a MORB-like source. As volcanoes erupt farther off axis, the overlying lithosphere continues to remove melt, and transfer of material from enriched sources becomes more significant.

The $\mathrm{Pb}, \mathrm{Sr}$ and $\mathrm{Nd}$ isotope systematics of glasses from Shimada seamount are similar to isotope compositions observed at some Pacific hotspots like Samoa. The high ${ }^{207} \mathrm{~Pb} /{ }^{204} \mathrm{~Pb}$ requires ancient $(>2 \mathrm{Ga})$ isolation of $\mathrm{Pb}$ in the source region. This ancient "Dupal" component is 
not restricted to the southern hemisphere. Shimada seamount shows no evidence for significant He isotope disequilibrium between vesicles and glass, consistent with the apparent young age and rapid growth of this volcano; the ${ }^{3} \mathrm{He} /{ }^{4} \mathrm{He}$ ranges between $3.9-4.8 \mathrm{R}_{\mathrm{a}}$ and one sample has relatively high $[\mathrm{He}]\left(>10^{-6} \mathrm{cCSTP} / \mathrm{g}\right)$. If the ${ }^{3} \mathrm{He} /{ }^{4} \mathrm{He}$ at Shimada seamount has been lowered from typical MORB ratios by separation of U+Th from He during evolution of the lower lithosphere, such a process began prior to $5 \mathrm{~m} . \mathrm{y}$. ago, when the 1 ithosphere was younger than $15 \mathrm{~m} . \mathrm{y}$. old. Alternatively the low ${ }^{3} \mathrm{He} /{ }^{4} \mathrm{He}$ is a source characteristic and possibly reflects the presence of a recycled component with high $\left(U_{+} T h\right) / H e$ in the mantle source region, as proposed for Tristan da Cunha and Gough Island (Kurz et al., 1982a) and for the post-erosional lavas at Samoa (Wright and White, 1987).

$\mathrm{He}-\mathrm{Sr}$ and $\mathrm{He}-\mathrm{Pb}$ isotope considerations suggest the presence of a low ${ }^{3} \mathrm{He} /{ }^{4} \mathrm{He}$ component in the sub-Pacific mantle. Potential lowering by radiogenic contamination of magma complicates precise interpretation of ${ }^{3} \mathrm{He} /{ }^{4} \mathrm{He}$ source characteristics for the small EPR seamount alkali basalts. Results of simple models suggest that the time since separation of $(U+T h)$ from $\mathrm{He}$ (and potentially the time since magma genesis) is $\sim 10^{4}-10^{5}$ years for alkalic lavas erupted at near axis seamounts, similar to time-scales estimated from U-Th series disequilibrium in MORB. 
CHAPTER 5

HELIUM AND LEAD ISOTOPE SYSTEMATICS IN SOUTH ATLANTIC MORB AND VOLCANIC ROCKS FROM THE ISLAND OF ST. HELENA 
In this chapter I discuss helium isotope results for mid-ocean ridge basalt glasses dredged from the South Atlantic, between $0-46^{\circ} \mathrm{S}$, and for phenocrysts in lavas from the island of St. Helena. Some of the MORB samples (from AII 107-7) were previously studied for He isotopes by Kurz (1982). Samples have been analyzed for major and trace elements by X-ray fluorescence (Humphris et al., 1985; Schilling et al., 1985, Humphris, unpublished data) providing a good petrologic and geochemical data base: with which to discuss the He results. Most of the MORB samples have also been analyzed for $\mathrm{Pb}$ isotopes by Hanan et a1. (1986). Whole rock powders from St. Helena were analyzed for $\mathrm{Pb}$ isotopes. The results show that ${ }^{3} \mathrm{He} /{ }^{4} \mathrm{He}$ ratios along much of the mid-ocean ridge in the South Atlantic are lower than normal MORB values (i.e., $<8.4 R_{A}$ ), and are correlated with $\mathrm{Pb}$ isotopes in specific cases. The $\mathrm{He}-\mathrm{Pb}$ isotope relationships are useful in characterizing ${ }^{3} \mathrm{He} /{ }^{4} \mathrm{He}$ in St. Helena material, and may have implications for the temporal evolution of He and $\mathrm{Pb}$ isotopes in mantle source regions.

\subsection{Isotope Variations in South Atlantic MORB and Oceanic Islands}

The South Atlantic is an intriguing area for isotopic study for several reasons. As outlined in chapter 1 , it may represent a regional boundary for mantle isotopic provinces. In addition, Schilling and co-investigators have suggested that the asthenosphere sampled by South Atlantic MORB contains material partly contaminated by nearby off-ridge hotspots (Schilling, 1985; Schilling et al., 1985; Humphris et al., 1985; 
Hanan et al., 1986). This is manifested by local bathymetric and geochemical anomalies. Spike-like anomalies in $(\mathrm{La} / \mathrm{Sm})_{\mathrm{N}}$ and $\mathrm{Pb}$ isotope ratios occur along the ridge at the latitudes of major islands. This has led them to pose the hotspot source - migrating-ridge sink model. In the South Atlantic, the mid-ocean ridge has been migrating westward in an absolute plate motion sense (i.e., fixed hotspot frame of reference) since $\sim 25 \mathrm{~m} . \mathrm{y}$. ago (Duncan, 1981). In the proposed mode1, a residual connection remains between the hotspot and ridge during ridge migration away form the hotspot. As a consequence, the width of geochemical anomalies along the ridge is inversely related to radial distance from the hotspot (Schilling, 1985; Hanan et a1., 1986). Hanan et al. (1986) showed that the ridge is segmented with respect to axial $(\mathrm{La} / \mathrm{Sm})_{N}$ and $\mathrm{Pb}$ isotope variations. "These segments appear to be discrete units in terms of nearby hotspot influence. These segments include $2-12^{\circ} \mathrm{S}$ (apparently associated with Circe seamount to the east), $12-20^{\circ} \mathrm{S}$ (St. Helena), $20-30^{\circ} \mathrm{S}$ (a transition region), and $31-46^{\circ} \mathrm{S}$ (Tristan da Cunha and Gough Island). The latter segment shows three separate spike-like anomalies in $(\mathrm{La} / \mathrm{Sm})_{N}$, termed $\mathrm{T}-1, \mathrm{~T}-2$, and $\mathrm{T}-3$ (see Fig. 5.4). The inferred mixing relationships for the respective ridge segments show considerable variability, which suggests that the mixing process is highly irregular. Collectively, at least two distinct mixing trends have been discerned. One trend, for MORB erupted along the Tristan platform, has the Tristan component and depleted MORB mantle as end-members; apparent mixing trends for the more northerly segments associated with St. Helena and Circe are distinct from the Tristan trend, having 
different enriched and depleted end-members (Hanan et al., 1986; Cole et a)., 1985).

Within the South Atlantic basin, at least three discrete mantle components are present, represented by MORB, Walvis Ridge-Tristan da Cunha-Gough, and St. Helena (depleted MORB mantle, EM 1 and HIMU, respectively). DM (depleted mantle) is well characterized with respect to helium $\left(\sim 8.4 R_{A}\right)$. EM 1, to the extent that it is represented by Gough Island and Tristan da Cunha, has ${ }^{3} \mathrm{He} /{ }^{4} \mathrm{He}$ less than MORB, between $\sim 5-6 R_{A}$. Characterizing ${ }^{3} \mathrm{He} /{ }^{4} \mathrm{He}$ for HIMU is somewhat problematic. The last volcanic activity at the island of St. Helena was prior to 7 m.y. ago (Abdel-Monem and Gast, 1967; Baker et a1., 1967); due to the long time since eruption and high $\left(U_{+} T h\right) /{ }^{3} \mathrm{He}$ in alkaline lavas, it is difficult to unequivocally reconstruct the inherited He isotope signature of this hotspot. However, as discussed above, $\mathrm{Pb}$ isotope signatures characteristic of St. Helena material have been identified along the ridge. These MORB glasses are "zero age" rocks, and therefore provide a unique opportunity to corroborate the He isotope results obtained by directly analyzing St. Helena lavas. They also provide additional information about the influence of mantle dynamics on $\mathrm{He}$ hotspot signatures along the mid-ocean ridge.

MORB samples were obtained from dredges taken aboard cruise AII 107-7, EN 061 and EN 063. Locations are shown in Fig. 5.1. The axial variations in $\mathrm{Pb}$ isotope ratios (from Hanan et al., 1986) are reproduced in Fig. 5.2, and given in Table 5.1 for samples analyzed here for ${ }^{3} \mathrm{He} /{ }^{4} \mathrm{He}$. 
Figure 5.1 Dredge locations of South Atlantic MORB samples from EN 061 , EN 063 and AII 107-7. 


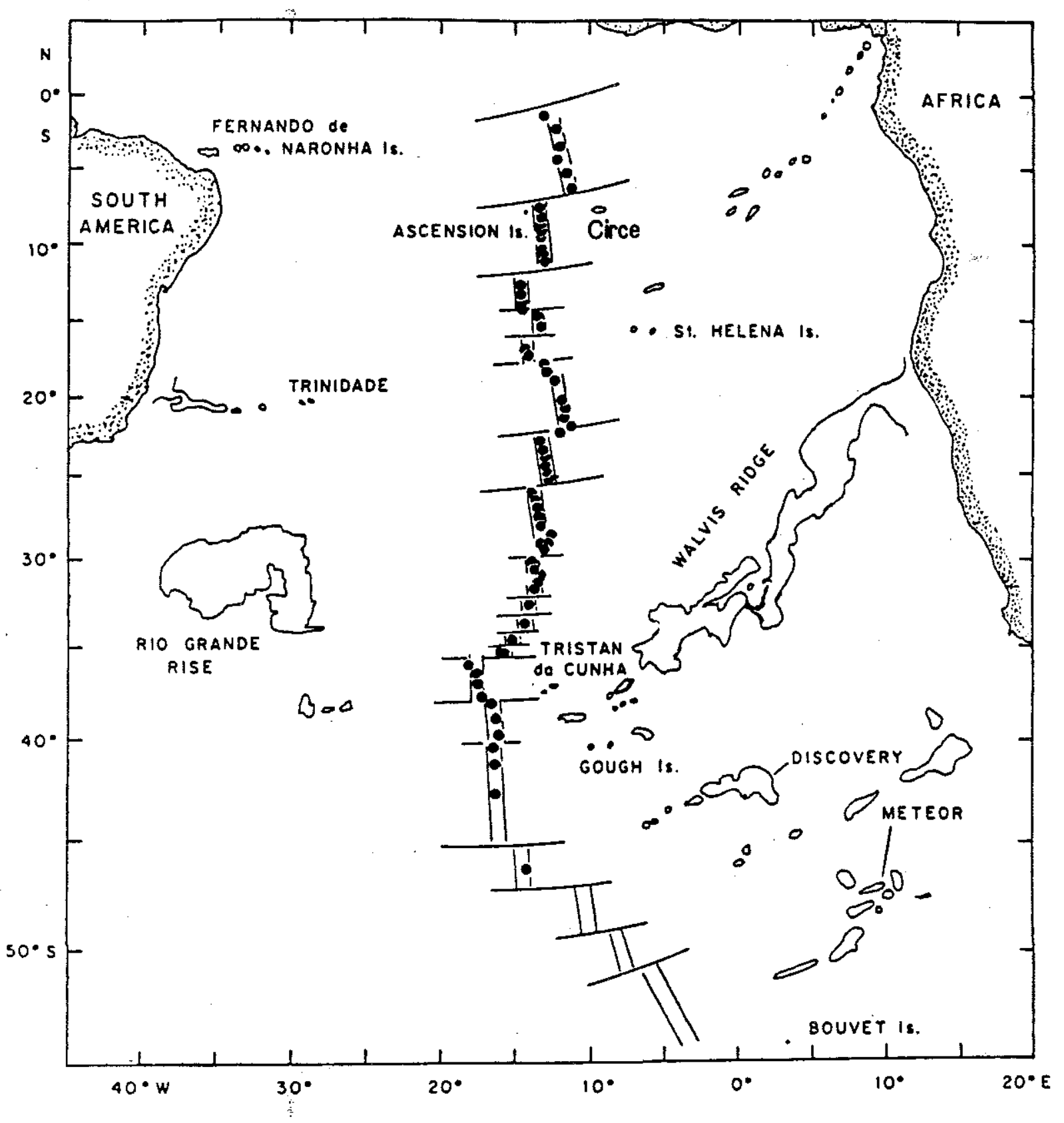


Figure 5.2 $\mathrm{Pb}$ isotope variations in the South Atlantic along the ridge axis (from Hanan et al., 1986). Solid symbols show samples analyzed for He isotopes, half-filled symbols are those for which samples from the same dredge have been analyzed. 


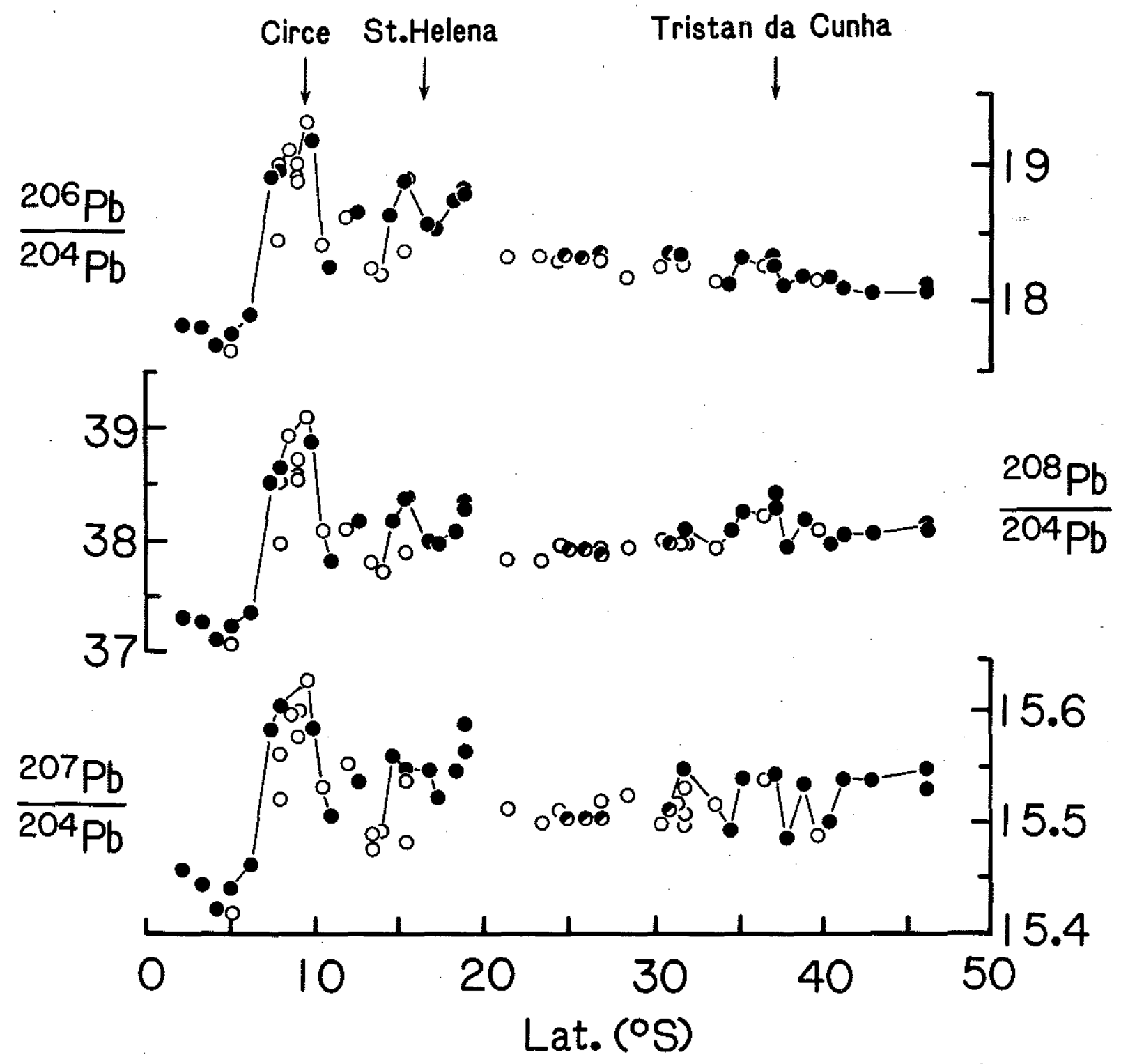




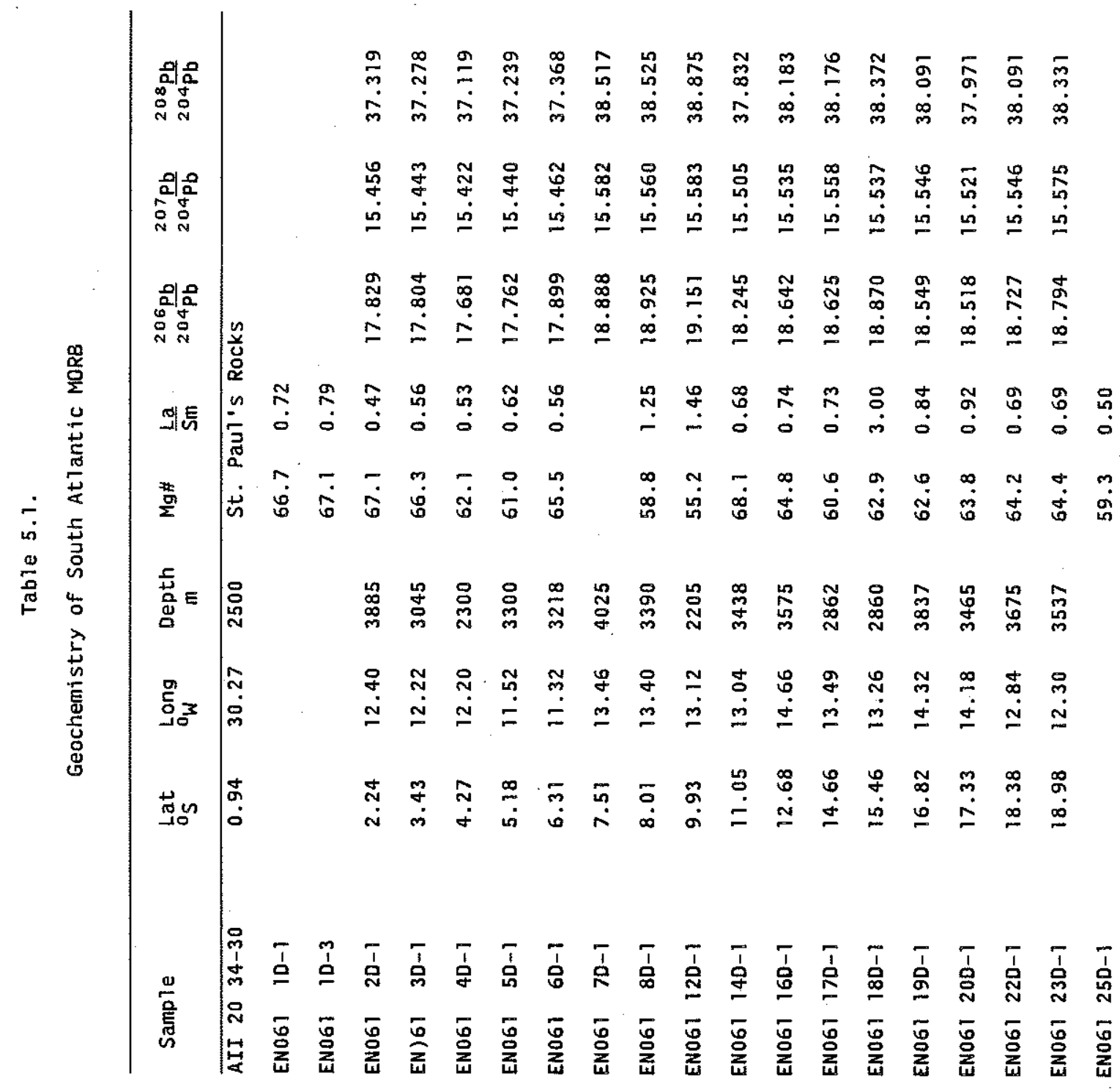




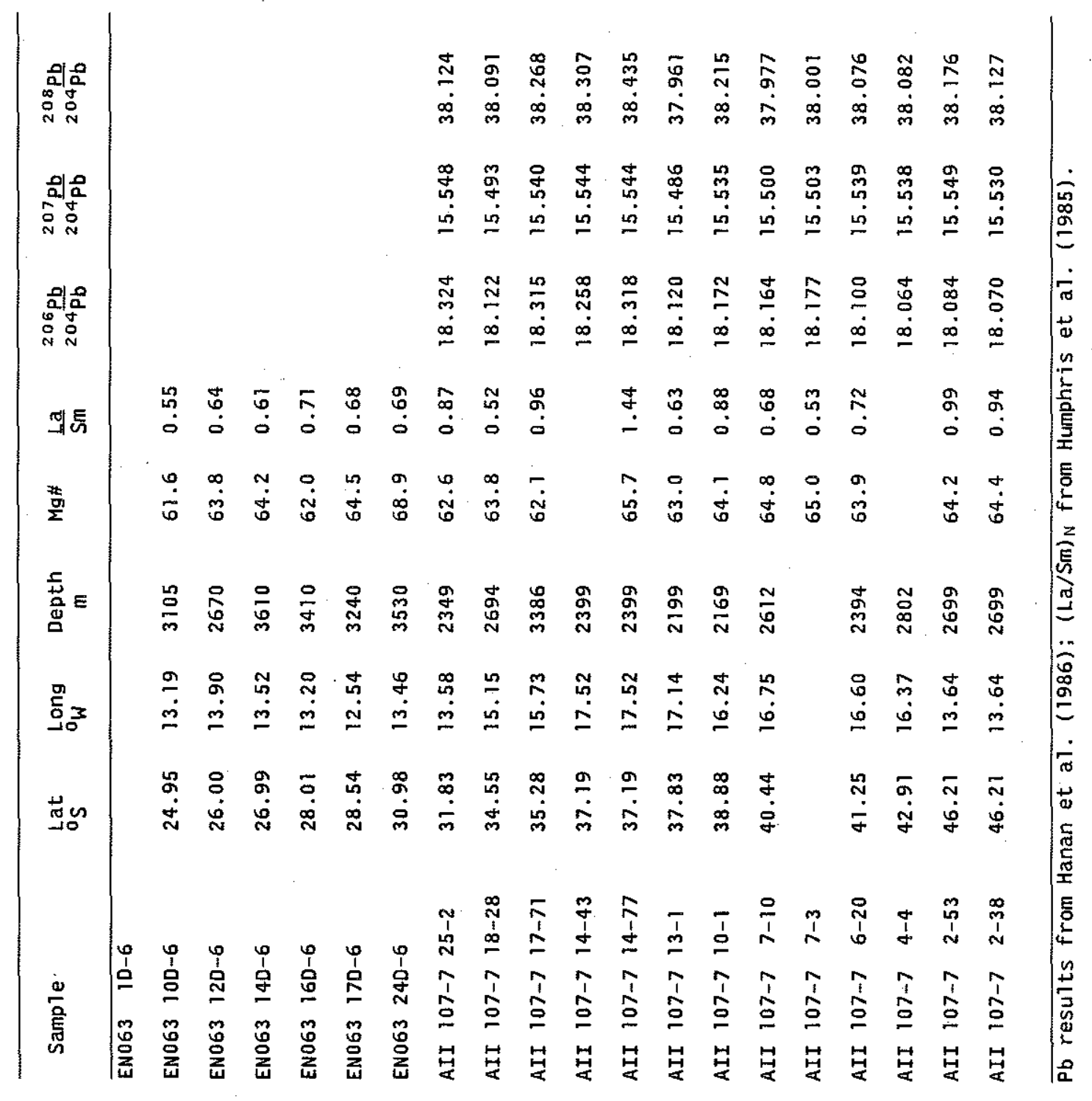




\subsection{St. Helena}

The island of St. Helena, located at $16^{\circ} 00^{\prime} \mathrm{S} 5^{\circ} 40^{\prime} \mathrm{W}$, is $\sim 120$ $\mathrm{km}^{2}$ in area. It consists of two coalesced shield volcanoes (Baker, 1969). The smaller northeastern volcano was largely buried beneath the flanks of the main southwestern shield after a subaerial lifetime of approximately $3 \mathrm{~m} . y$. , between 14.6-11.4 m.y. ago. After volcanic activity shifted to the southwest (about $12 \mathrm{~km}$ away) the new center continued to erupt for another $\sim 3 \mathrm{~m} . \mathrm{y}$. , between $11.3-8.5 \mathrm{~m} . \mathrm{y}$. ago. In the later stages, highly alkaline dikes intruded the center and upper flanks of the southwestern shield at approximately $7.5 \mathrm{~m} . \mathrm{y}$. ago. Thus the total subaerial 1 ifetime was $\sim 7.5 \mathrm{~m} . \mathrm{y}$ (Baker et al., 1967). Ankaramites and picritic basalts are found at stratigraphically low levels; these were extruded early in the history of the island and may be accumulative (Baker, 1969). For the lower and the main shields, basalts occur at all levels, but intermediate rocks such as trachybasalts and trachytes are volumetrically more abundant. These were produced primarily by low pressure differentiation of the parental basalt, and the final phases of volcanism produced the most highly differentiated rock types. Volumetrically, basalts comprise $\sim 70-80 \%$, trachybasalts 15-25\%, and trachytes and phonolites <5\% (Baker, 1969).

Five samples encompassing the range of rock types found at St. Helena have been studied. Sample locations are shown in Fig. 5.3 and sample descriptions are given in Appendix 1. Whole rock powders were analyzed for $\mathrm{Pb}$ isotopes, and phenocrysts from three samples were analyzed for ${ }^{3} \mathrm{He} /{ }^{4} \mathrm{He}$ by crushing in vacuo as outlined in chapter 2 . 
Figure 5.3 Location of St. Helena samples analyzed for He and $\mathrm{Pb}$ isotopes (after Baker, 1969). 


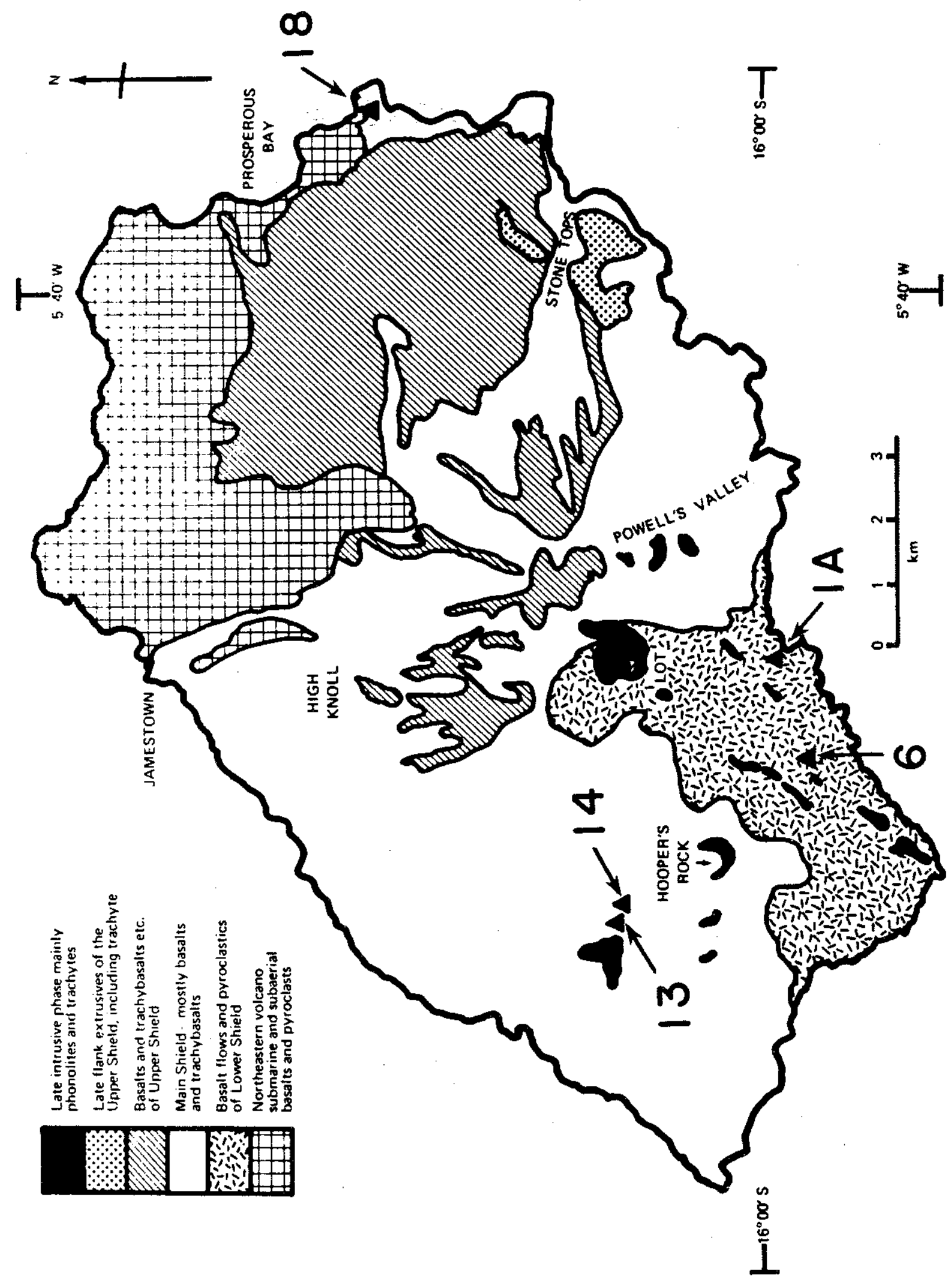




\subsection{Results and Discussion}

\subsubsection{He in South Atlantic MORB}

He isotope results for South Atlantic MORB are given in Table 5.2. The along axis variations in ${ }^{4} \mathrm{He} /{ }^{3} \mathrm{He}$ atom ratio are displayed in Fig. 5.4, along with $(\mathrm{La} / \mathrm{Sm})_{N}$ and bathymetry. Along the Circe segment $\left(2-12^{\circ} \mathrm{S}\right){ }^{4} \mathrm{He} /{ }^{3} \mathrm{He}$ increases southward until the vicinity of the St. Helena segment. Between $12-20^{\circ} \mathrm{S}$, the local variability in ${ }^{4} \mathrm{He} /{ }^{3} \mathrm{He}$ is large. The two samples from the St. Helena ridge segment with the strongest radiogenic He signatures are not found precisely at the latitude of the St. Helena flow 1 ine $\left(\sim 17^{\circ} \mathrm{S}\right)$ but are found at its distal ends. These samples also show more radiogenic $\mathrm{Pb}$ compositions. If the isotopic signatures are representative (i.e., they are not biased by the limited sampling) then a dynamic process may be operative whereby St. Helena material is more readily sampled by ridge axis volcanism near $12^{\circ} \mathrm{S}$ and $20^{\circ} \mathrm{S}$. The samples dredged at $12^{\circ}$ and $20^{\circ}$ are from just south of a right lateral offset (Bode Verde F.Z.) and north of a left lateral offset (Martin Vaz F.Z.), respectively. Although very speculative, perhaps the extent to which St. Helena material is sampled by axial volcanism is related to flow boundaries in the mantle, as manifested by fracture zones in the overlying lithosphere. South of $20^{\circ} \mathrm{S},{ }^{4} \mathrm{He} /{ }^{3} \mathrm{He}$ shows $\sim 10 \%$ variability. A local spike-like anomaly, similar to that for $(\mathrm{La} / \mathrm{Sm})_{N}$, occurs at the latitude of Tristan da Cunha.

He isotope results for South Atlantic MORB are shown in histogram fashion in Fig. 5.5. The mean ${ }^{3} \mathrm{He} /{ }^{4} \mathrm{He}$ in South Atlantic MORB is 
Figure 5.4 Axial variations of ${ }^{4} \mathrm{He} /{ }^{3} \mathrm{He}$ (atom ratio), (La/Sm) and bathymetry for South Atlantic MORB. Uncertainties in ${ }^{4} \mathrm{He} /{ }^{3} \mathrm{He}$ are $\pm 2 \sigma$. 


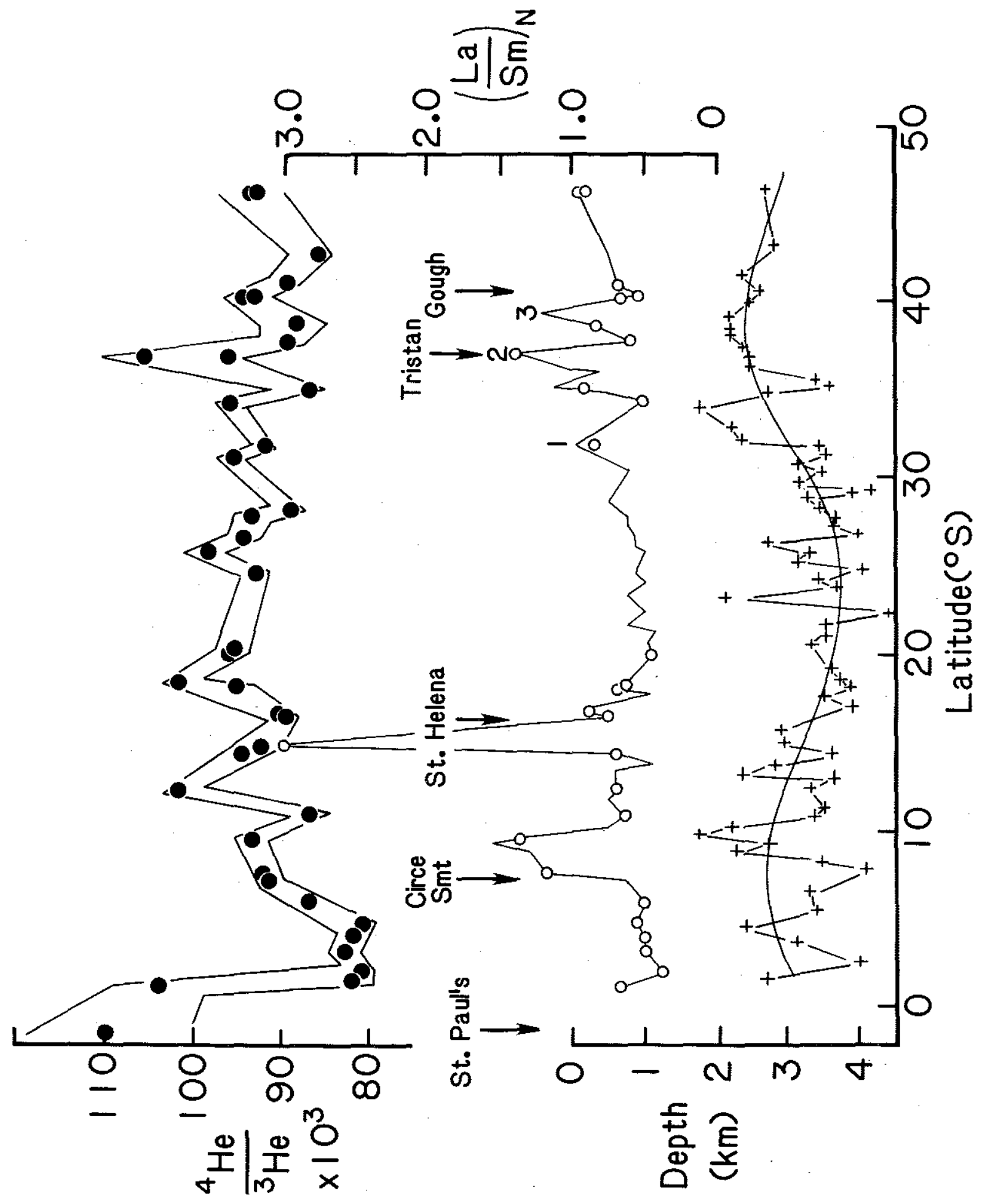


Figure 5.5 Histogram of ${ }^{3} \mathrm{He} /{ }^{4} \mathrm{He}$ in South Atlantic MORB. Ridge segments were selected following Hanan et al (1986); Circe -- $2-12^{\circ} \mathrm{S}$; St. Helena -- $12-22^{\circ} \mathrm{S}$; transition segment -- $22-30.75^{\circ} \mathrm{S}$; Tristan segment is $30.75-46^{\circ} \mathrm{S}$, with T-1 - $30.75-34^{\circ} \mathrm{S}, \mathrm{T}-2-\mathrm{C}^{-} 34-39^{\circ} \mathrm{S}$ and T-3 -$39-46^{\circ} \mathrm{S}$. 


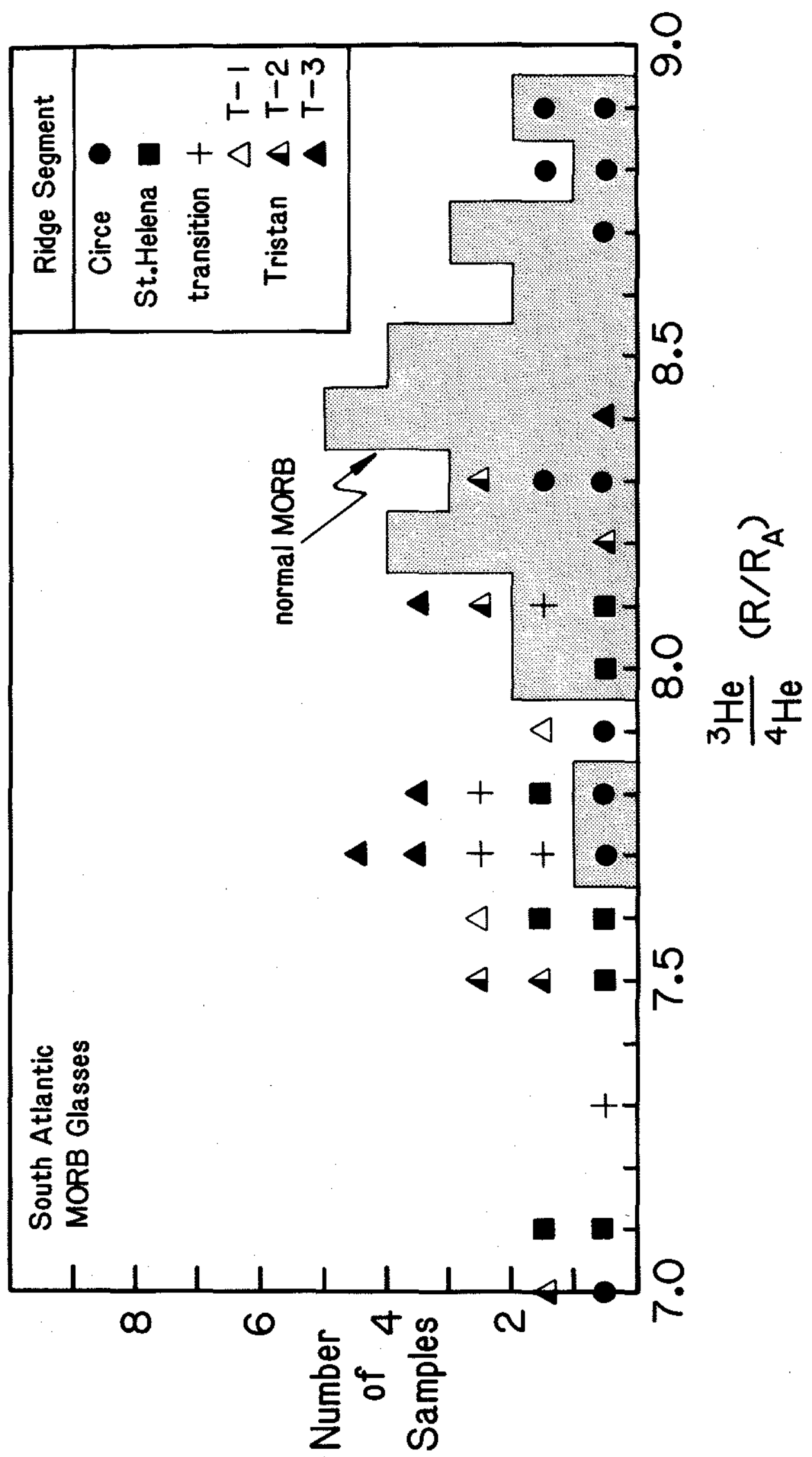




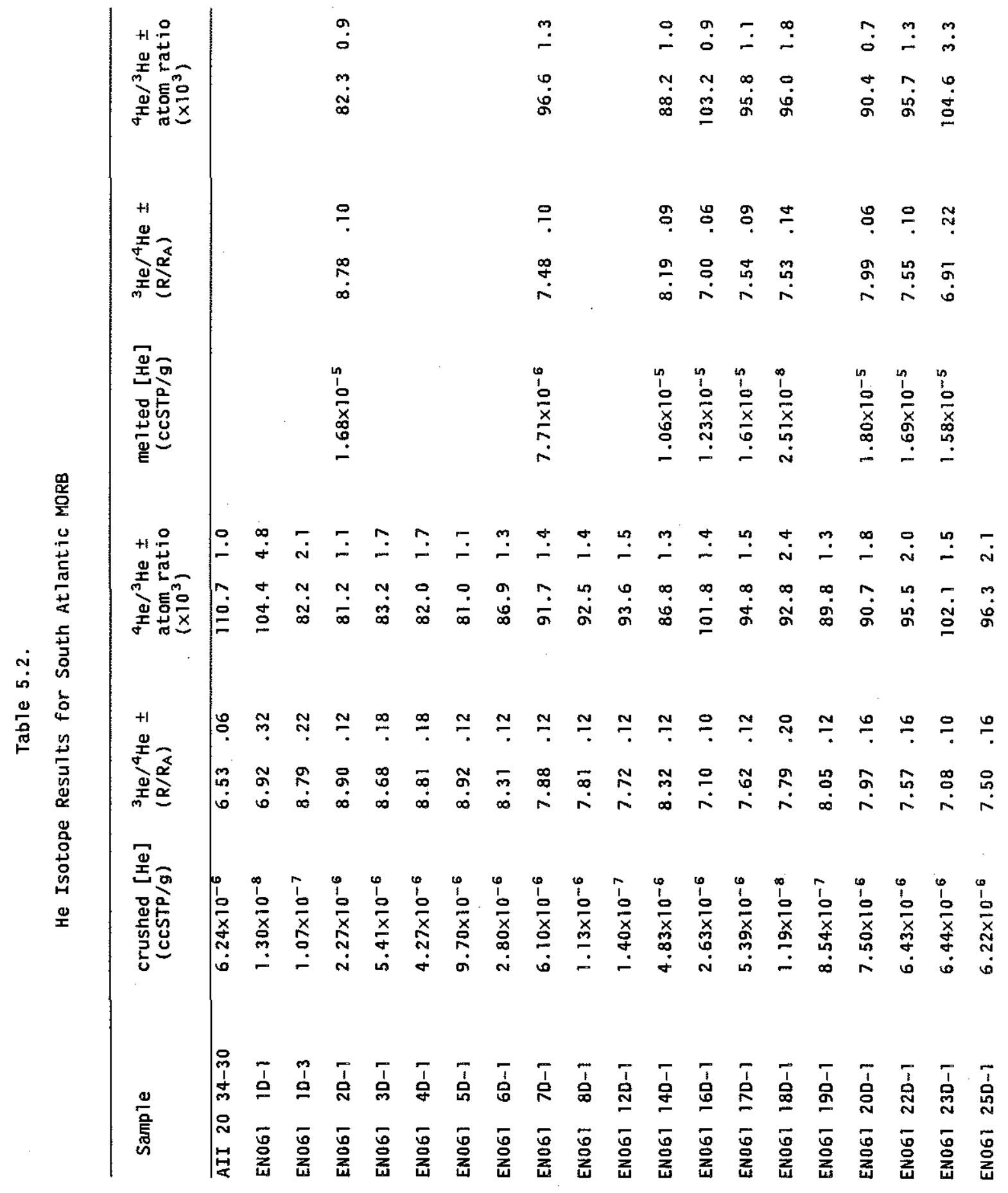




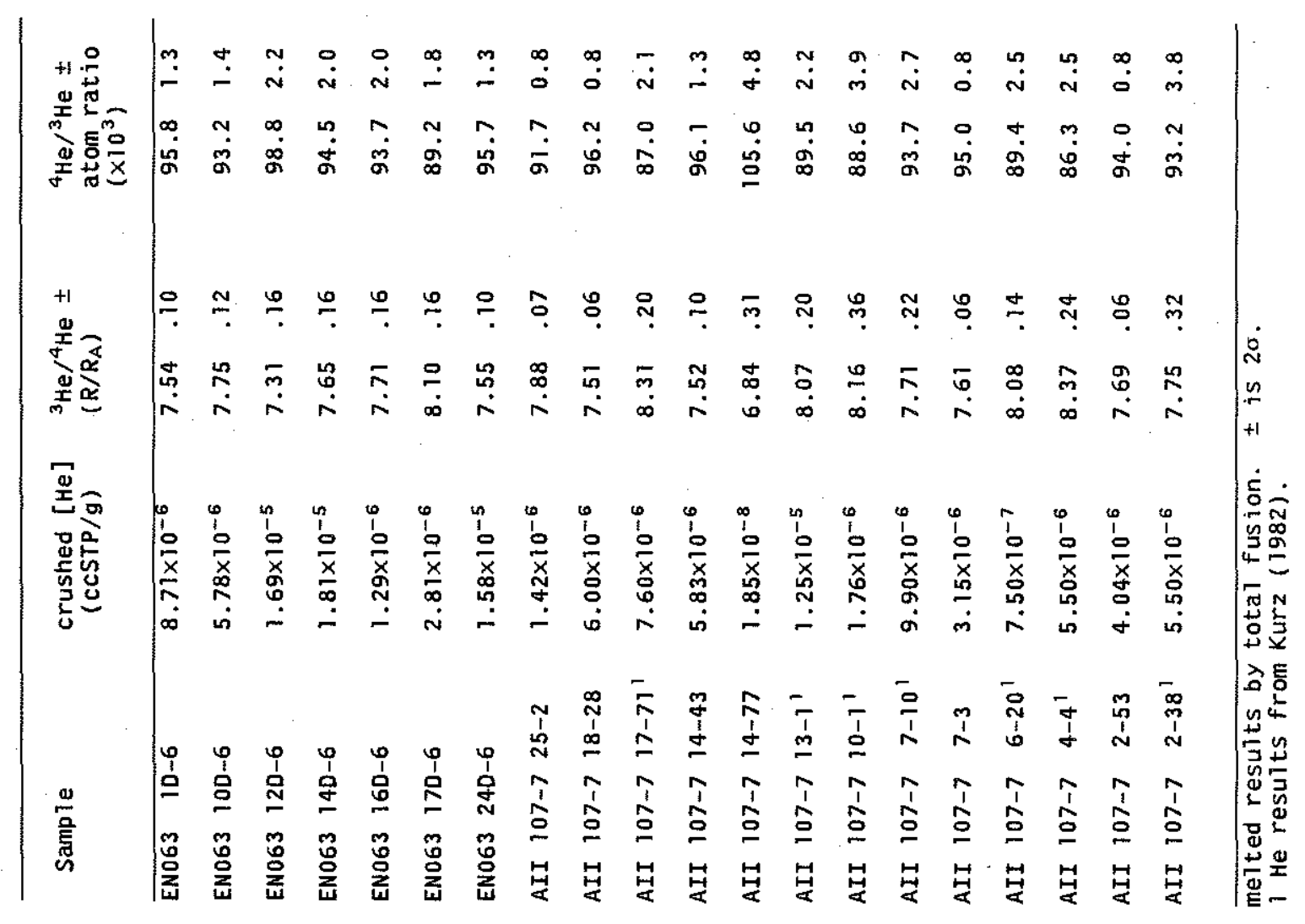


significantly lower (greater than $99 \%$ confidence level with T-test) than the mean value for "normal" MORB (mean ${ }^{3} \mathrm{He} /{ }^{4} \mathrm{He}=7.87 \mathrm{R}_{\mathrm{A}}$ in the $\mathrm{S}$. Atlantic vs. $8.40 \mathrm{R}_{\mathrm{A}}$ for N-MORB; Kurz, 1982; see Table 5.3). Such a simple statistical comparison is complicated by several effects however, which include 1) the possibility that the data sets may not truly represent normal distributions, and 2) samples from the South Atlantic with radiogenic $\mathrm{Pb}$ signatures were preferentially analyzed (see Fig. 5.2). However, the Circe segment $\left(2-12^{\circ} \mathrm{S}\right)$ displays the most radiogenic $\mathrm{Pb}$ signatures along the ridge, yet the mean ${ }^{3} \mathrm{He} /{ }^{4} \mathrm{He}$ is indistinguishable from normal MORB. This segment is also characterized by some of the least radiogenic ${ }^{87} \mathrm{Sr} /{ }^{86} \mathrm{Sr}$ ratios found in MORB, as low as 0.70214 (Cole et al., 1985). The St. Helena (mean ${ }^{3} \mathrm{He} /{ }^{4} \mathrm{He}=$ $7.58 R_{A}$ ) and Gough-Tristan da Cunha ridge segments (mean ${ }^{3} \mathrm{He} /{ }^{4} \mathrm{He}=$ $7.79 \mathrm{R}_{\mathrm{A}}$ ) appear to have ${ }^{3} \mathrm{He} /{ }^{4} \mathrm{He}$ lower than normal MORB. The distance between the ridge axis and the respective islands ranges between 400-800 km. In the hotspot source-ridge sink model, this distance plays a role when comparing mean ${ }^{3} \mathrm{He} /{ }^{4} \mathrm{He}$ values. The variability in ${ }^{3} \mathrm{He} /{ }^{4} \mathrm{He}$ along the ridge, and the limited number of analyses, make mixing relationships with nearby hotspot materials difficult to define. A more extensive data set for ${ }^{3} \mathrm{He} /{ }^{4} \mathrm{He}$ is required. A particularly important test will be the degree of ${ }^{3} \mathrm{He} /{ }^{4} \mathrm{He}$ variability at one location, because single dredge hauls display a range of trace element ratios (Schilling et al., 1985).

${ }^{3} \mathrm{He} /{ }^{4} \mathrm{He}$ is shown against $(\mathrm{La} / \mathrm{Sm})_{N}$ in $\mathrm{Fig}, 5.6$. The circe ridge segment shows a negative correlation, suggesting at least two possibilities; 1) two-component mixing of depleted MORB mantle and a 
Figure $5.6 \quad{ }^{3} \mathrm{He} /{ }^{4} \mathrm{He}$ vs. $(\mathrm{La} / \mathrm{Sm})_{N}$ for South Atlantic MORB. Sample designations as for Fig. 5.5; open cicle is from north of the Circe segment. 


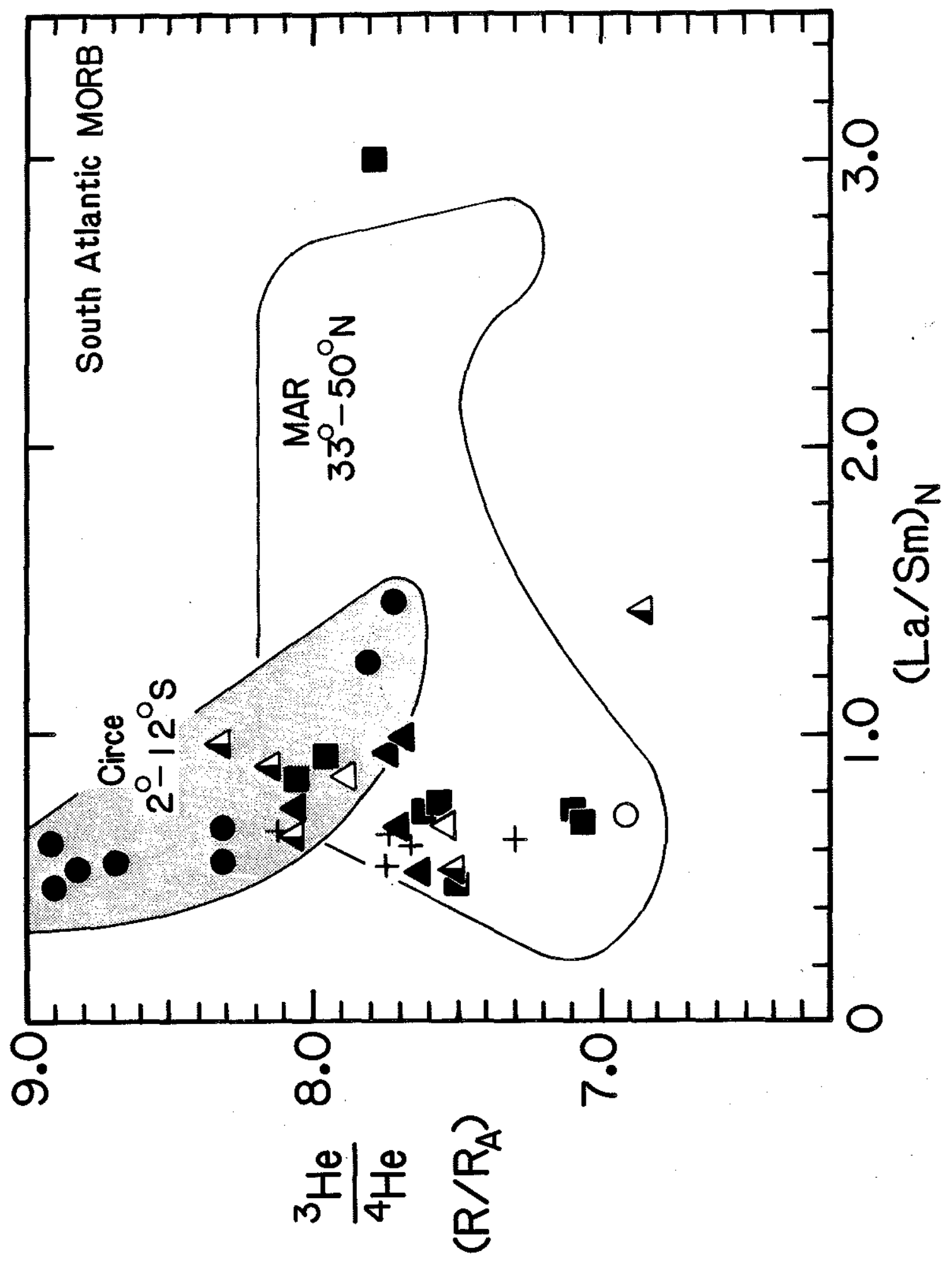


Table 5.3.

Comparison of ${ }^{3} \mathrm{He} /{ }^{4} \mathrm{He}$ for South Atlantic MORB

\begin{tabular}{lccc}
\hline $\begin{array}{c}\text { Ridge } \\
\text { Segment }\end{array}$ & $\begin{array}{c}\text { mean } \\
{ }^{3} \mathrm{He} /{ }^{4} \mathrm{He} \\
\left(\mathrm{R} / \mathrm{R}_{\mathrm{A}}\right)\end{array}$ & $\sigma$ & $\mathrm{n}$ \\
\hline $\begin{array}{c}\text { Circe } \\
2-12^{\circ} \mathrm{S}\end{array}$ & 8.37 & 0.48 & 9 \\
$\begin{array}{c}\text { St. Helena } \\
12-22^{\circ} \mathrm{S}\end{array}$ & 7.58 & 0.34 & 9 \\
$\begin{array}{c}\text { transition } \\
22-30.75^{\circ} \mathrm{S}\end{array}$ & 7.70 & 0.28 & 5 \\
$\begin{array}{c}\text { Tristan } \\
30.75-46^{\circ} \mathrm{S}\end{array}$ & 7.79 & 0.40 & 14 \\
$\begin{array}{c}\text { South Atlantic } \\
2-46^{\circ} \mathrm{S}\end{array}$ & 7.87 & 0.48 & 37 \\
$\mathrm{~N}-\mathrm{MORB}$ & 8.40 & 0.36 & 32 \\
\hline
\end{tabular}


large ion lithophile (LIL) element-enriched source has occurred, or 2) at low degrees of melting, a component with lower ${ }^{3} \mathrm{He} /{ }^{4} \mathrm{He}$ contributes proportionately more $\mathrm{He}$, possibly from $\left(U_{+} T h\right) /{ }^{3} \mathrm{He}$ variability in the underlying mantle source. Systematic ${ }^{3} \mathrm{He} /{ }^{4} \mathrm{He}-(\mathrm{La} / \mathrm{Sm})_{\mathrm{N}}$ relationships are not present for the other ridge segments. Most notably, EN $061180-1$, the sample with the highest $(\mathrm{La} / \mathrm{Sm})_{\mathrm{N}}(\sim 3.0)$ occurs along the St. Helena ridge segment; it also has alkaline affinities, being slightly nepheline normative (characteristic of St. Helena). This sample has the lowest [He] of any MORB samples analyzed but it has intermediate ${ }^{3} \mathrm{He} /{ }^{4} \mathrm{He}\left(7.8 \mathrm{R}_{\mathrm{A}}\right)$. Low He concentrations appear to be associated with higher $(\mathrm{La} / \mathrm{Sm})_{\mathrm{N}}$ in some other MORB samples (e.g., AII107-7, 14-77 from the Tristan segment). Low [He] and high $(\mathrm{La} / \mathrm{Sm})_{N}$ are also characteristic of alkali basalts erupted at small seamounts near the East Pacific Rise (chapter 4). The alkaline affinities, low ${ }^{3} \mathrm{He} /{ }^{4} \mathrm{He}$ and high $(\mathrm{La} / \mathrm{Sm})_{\mathrm{N}}$ in some oceanic rocks may have similar origins (e.g., similar recycled materials). The exact $\mathrm{He}-\mathrm{Pb}-\mathrm{Sr}-\mathrm{Nd}$ isotopic character is, of course, not the same in all erupted products with these He and La/Sm properties. This may in part be related to differences in residence time of the materials in the convecting upper mantle, and to the contrasting style in which volcanism at ridges, seamounts and islands samples the underlying mantle during magma genesis. In addition, metasomatic processes may lead to elevated $\left(U_{+} T h\right) /{ }^{3} \mathrm{He}$ and $(\mathrm{La} / \mathrm{Sm})_{N}$ in the different tectonic provinces. If such events occurred recently $\left(\sim 10^{7}\right.$ y ago $)$ they might produce dramatic changes in ${ }^{3} \mathrm{He} /{ }^{4} \mathrm{He}$ and $\mathrm{La} / \mathrm{Sm}$ while leaving ${ }^{206} \mathrm{~Pb} /{ }^{204} \mathrm{~Pb}$, ${ }^{87} \mathrm{Sr} /{ }^{86} \mathrm{Sr}$ and ${ }^{143} \mathrm{Nd} / /^{144} \mathrm{Nd}$ relatively unaffected. 
${ }^{3} \mathrm{He} /{ }^{4} \mathrm{He}$ along the ridge also does not appear related in a simple way to $\mathrm{Mg} \#$ (Fig. 5.7). Assuming that variations in $\mathrm{Mg} \#$ of the observed magnitude predominantly reflect crystal fractionation processes, this precludes the possibility that the low ${ }^{3} \mathrm{He} /{ }^{4} \mathrm{He}$ in these samples is solely due to modification of a constant ${ }^{3} \mathrm{He} /{ }^{4} \mathrm{He}$ source ratio by radiogenic ingrowth in magmas with high $(U+T h) /{ }^{3} \mathrm{He}$. (Such an effect might be expected in association with longer residence times (lower Mg \#) in magma chambers undergoing more extensive fractional crystallization, such as discussed in chapter 4.) In fact, a weak negative relationship between ${ }^{3} \mathrm{He} /{ }^{4} \mathrm{He}$ and $\mathrm{Mg} \#$ is observed along both the St. Helena and Gough-Tristan da Cunha segments, suggesting that more primitive magmas may have lower ${ }^{3} \mathrm{He} /{ }^{3} \mathrm{He}$, possibly in association with stronger hotspot signatures.

\subsubsection{He-Pb Isotopic Variations in South Atlantic MORB}

In the following discussion, variations in ${ }^{4} \mathrm{He} /{ }^{3} \mathrm{He}$ (the inverse of ${ }^{3} \mathrm{He} /{ }^{4} \mathrm{He}$ ) are coupled to those in radiogenic $\mathrm{Pb}$ isotope ratios, because the issue of temporal evolution in the mantle source regions can be more readily addressed. ${ }^{4} \mathrm{He} /{ }^{3} \mathrm{He}$ is shown against the three $\mathrm{Pb}$ isotope ratios in Fig. 5.8-5.10. The Circe segment shows the most systematic relationship, where ${ }^{4} \mathrm{He} /{ }^{3} \mathrm{He}$ is linearly correlated with all three $\mathrm{Pb}$ isotope ratios. ${ }^{4} \mathrm{He} /{ }^{3} \mathrm{He}$ also increases with radiogenic $\mathrm{Pb}$ along the $\mathrm{St}$. Helena segment, but with more scatter. He-Pb results for the Tristan platform are more complex, but also are consistent with mixing of MORB mantle and material of similar isotopic compositon to Tristan da Cunha and Gough. 
Figure $5.7{ }^{3} \mathrm{He} /{ }^{4} \mathrm{He}$ vs. Mg\# for South Atlantic MORB. Sample designations as for Fig. 5.5. 


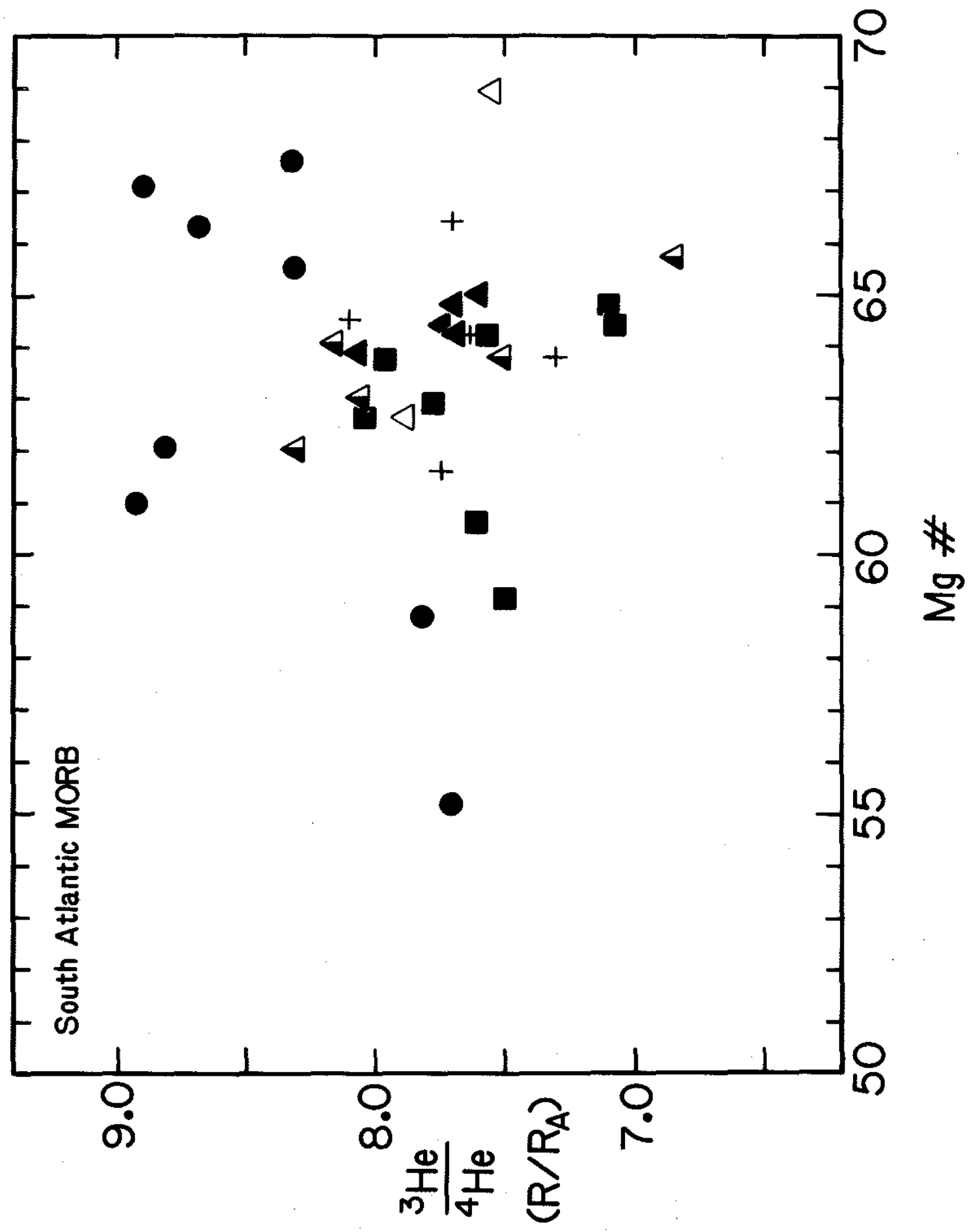


Figure $5.8{ }^{4} \mathrm{He} /{ }^{3} \mathrm{He}$ vs. ${ }^{206} \mathrm{~Pb} /{ }^{204} \mathrm{~Pb}$ for South Atlantic MORB. Range of ${ }^{206} \mathrm{~Pb} /{ }^{204} \mathrm{~Pb}$ at Walvis Ridge (Richardson et a1., 1982) and at Gough and Tristan da Cunha (Sun, 1980) are shown for comparison; ${ }^{4} \mathrm{He} /{ }^{3} \mathrm{He}$ for Gough and Tristan is from Kurz et al. (1982a). Selected MORB and St. Helena end-members are; MORB $-{ }^{206} \mathrm{~Pb} /{ }^{204} \mathrm{~Pb}=18.50$, ${ }^{207} \mathrm{~Pb} /{ }^{204} \mathrm{~Pb}=15.52,{ }^{208} \mathrm{~Pb} / 20{ }^{4} \mathrm{~Pb}=37.97$, ${ }^{4} \mathrm{He} /{ }^{3} \mathrm{He}=88.8 \times 10^{3}\left({ }^{3} \mathrm{He} /{ }^{4} \mathrm{He}=8.10 \mathrm{R}_{\mathrm{A}}\right) ; \mathrm{St}$. Helena $-{ }^{206} \mathrm{~Pb} /{ }^{204} \mathrm{~Pb}=20.70,{ }^{207} \mathrm{~Pb} / 20{ }^{4} \mathrm{~Pb}=15.77$, ${ }^{208} \mathrm{~Pb} /{ }^{204} \mathrm{~Pb}=40.00,{ }^{4} \mathrm{He} /{ }^{3} \mathrm{He}=120 \times 10^{3}$ $\left({ }^{3} \mathrm{He} /{ }^{4} \mathrm{He}=6.00 \mathrm{R}_{\mathrm{A}}\right)$. Mixing curves are shown for $\mathrm{R}$ $\left({ }^{3} \mathrm{He} /{ }^{204} \mathrm{~Pb}\right)=1$ and 10 . 


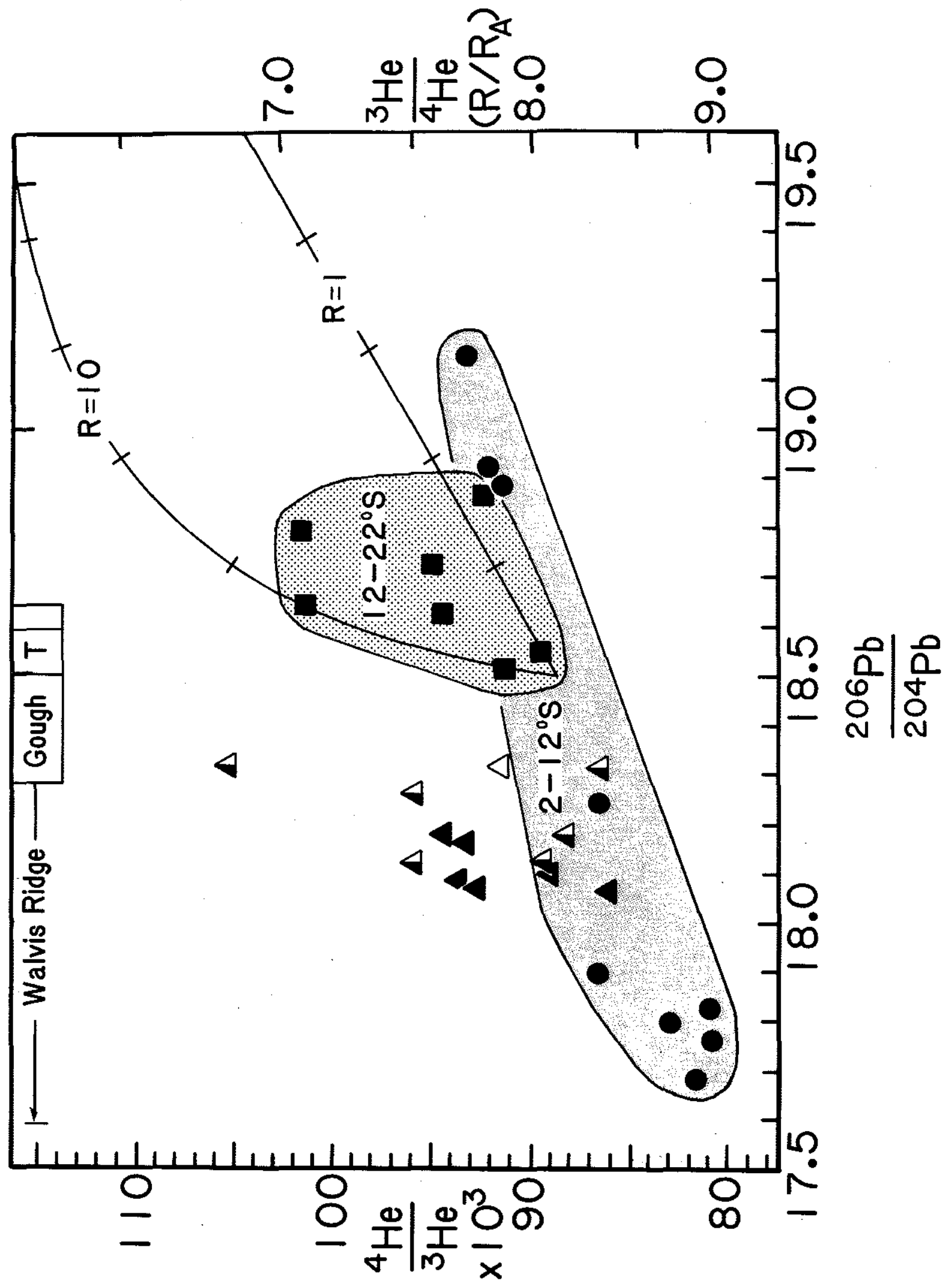


Figure $5.9{ }^{4} \mathrm{He} /{ }^{3} \mathrm{He}$ vs. ${ }^{207} \mathrm{~Pb} /{ }^{204} \mathrm{~Pb}$ for South Atlantic MORB.

Selected end-member compositions for mixing curves are given in caption to Fig. 5.8 . 


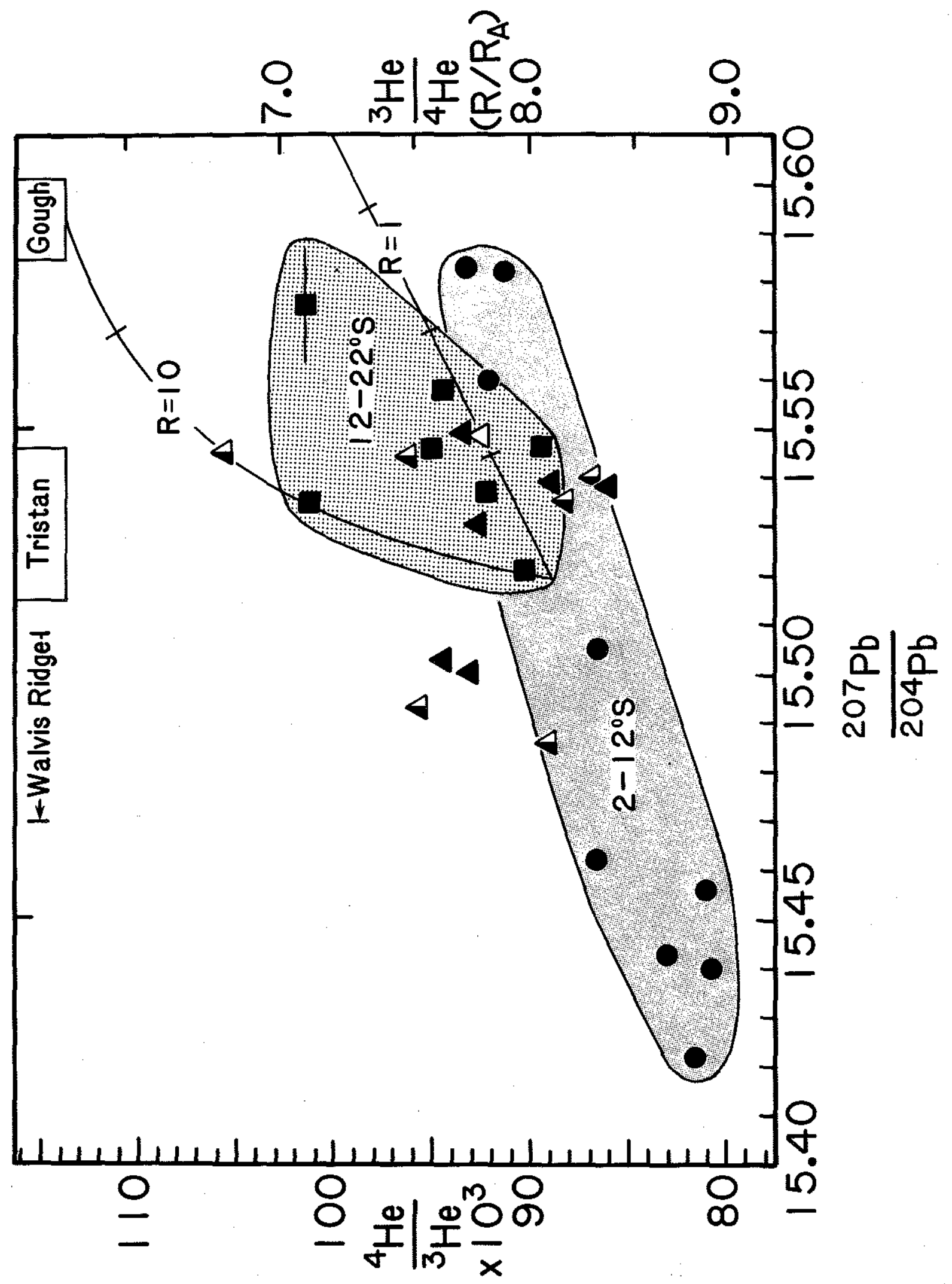


Figure $5.10{ }^{4} \mathrm{He} /{ }^{3} \mathrm{He}$ vs. ${ }^{208} \mathrm{~Pb} /{ }^{204} \mathrm{~Pb}$ for South Atlantic MORB.

Selected end-member compositions for mixing curves are given in caption to Fig. 5.8 . 


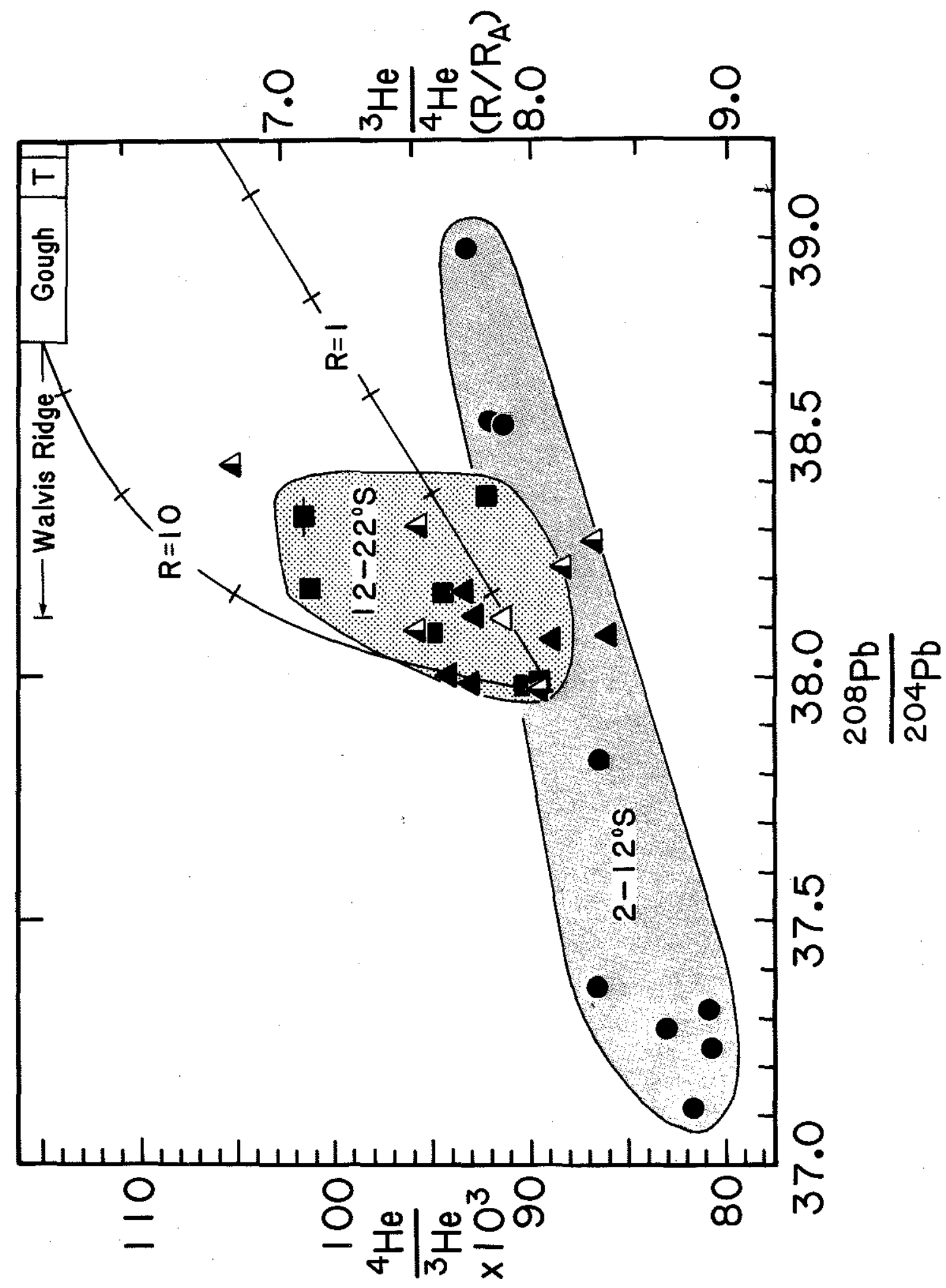


St. Helena is characterized by extremely radiogenic $\mathrm{Pb}$ $\left({ }^{206} \mathrm{~Pb} /{ }^{204} \mathrm{~Pb}>20.7\right)$, but the highest ${ }^{206} \mathrm{~Pb} /{ }^{204} \mathrm{~Pb}$ occurs along the Circe ridge segment, possibly related to the closer proximity of that hotspot. ${ }^{4} \mathrm{He} /{ }^{3} \mathrm{He}$ is highest along the St. Helena segment however, and shows a positive correlation with radiogenic $\mathrm{Pb}$ ( $\mathrm{Fig}, 5.8-5.10)$. This is evidence that St. Helena is characterized by ${ }^{4} \mathrm{He} /{ }^{3} \mathrm{He}$ higher than normal MORB values

Results of mixing calculations for selected end-members are also depicted in Fig. 5.8-5.10. Mixing trajectories are calculated following methods outlined by Langmuir et al. (1978), according to the following

$$
\begin{aligned}
& X_{m}=f X_{1}+(1-f) X_{2} \\
& Y_{m}=\{f /[f+R(1-f)]\} Y_{1}+\{R(1-f) /[f+R(1-f)]\} Y_{2}
\end{aligned}
$$

where $X$ and $Y$ are radiogenic isotope ratios, the subscripts 1,2 and $m$ denote relevant end-members and the two-component mixture, respectively, $f$ is the fraction contributed by component 1 of element $X$ in the mixture, and $R$ is the concentration ratio $(Y / X)_{2} /(Y / X)_{1}$. The St. Helena end-member was selected to have ${ }^{3} \mathrm{He} /{ }^{4} \mathrm{He} \simeq 6.0 \mathrm{R}_{\mathrm{A}}\left({ }^{4} \mathrm{He} /{ }^{3} \mathrm{He}=\right.$ $120 \times 10^{3}$ ) and ${ }^{205} \mathrm{~Pb} /{ }^{204} \mathrm{~Pb}=20.7$ ( similar to values measured in St. Helena basalts, discussed below). MORB end-members for the $2-12^{\circ} \mathrm{S}$ and $12-20^{\circ} \mathrm{S}$ segments were chosen to have isotope compositions similar to the most depleted values observed $\left({ }^{3} \mathrm{He} /{ }^{4} \mathrm{He}=8.90\right.$ and $8.10 \mathrm{R}_{\mathrm{A}}$ and ${ }^{206} \mathrm{~Pb} /{ }^{204} \mathrm{~Pb}=17.60$ and 18.50 , respectively). If mixing with a St. Helena component was responsible for the $\mathrm{He}-\mathrm{Pb}$ trend of the Circe segment, $R$ values of $0.5-1.0$ would be required ( $i . e .$, the enriched end-member would have ${ }^{3} \mathrm{He} /{ }^{20}{ }^{4} \mathrm{~Pb}$ similar to the depleted end-member with which it mixed). In addition, the depleted MORB material would be 
diluted by about $30 \%$ with the St. Helena end-member in order to produce the MORB end-member observed along the St. Helena segment. This scenario is unlikely for at least two reasons. Firstly, the Circe $\mathrm{Pb}-\mathrm{Pb}$ isotope trends are not consistent with St. Helena as an end-member (Hanan et al., 1986). Secondly, it is unlikely that hotspot material such as that at St. Helena (derived from a source other than depleted MORB mantle) has a similar ${ }^{3} \mathrm{He} /{ }^{204} \mathrm{~Pb}$ ratio. If mixing explains the $\mathrm{He}-\mathrm{Pb}$ isotopic variations along the Circe segment, Circe ${ }^{4} \mathrm{He} /{ }^{3} \mathrm{He}$ is higher than depleted MORB mantle. The precise value cannot be constrained solely from variations along the ridge. Ascension Island is located at about the same latitude as Circe but to the west of the ridge and is an unlikely candidate for the hotspot source in terms of the migrating ridge model. If the binary mixing model applies and Circe has $\mathrm{Pb}$ isotope compositions similar to Ascension, its ${ }^{4} \mathrm{He} /{ }^{3} \mathrm{He}$ should be $\sim 97 \times 10^{3}$ $\left(\sim 7.5 R_{A}\right)$. This also seems unlikely given the $\mathrm{Pb}-\mathrm{Pb}$ isotope trends for the Circe segment (Hanan et al., 1986).

An alternate explanation is that the linear ${ }^{4} \mathrm{He} /{ }^{3} \mathrm{He}$ ${ }^{206} \mathrm{~Pb} /{ }^{204} \mathrm{~Pb}$ correlation (and ${ }^{207} \mathrm{~Pb} /{ }^{204} \mathrm{~Pb}-{ }^{206} \mathrm{~Pb} / 204 \mathrm{~Pb}$ and ${ }^{208} \mathrm{~Pb} / 204 \mathrm{~Pb}^{206} \mathrm{~Pb} /{ }^{204} \mathrm{~Pb}$ correlations) is produced by coupled temporal evolution in the depleted mantle subunit giving rise to the MORB along the Circe segment. The ${ }^{4} \mathrm{He} /{ }^{3} \mathrm{He}-{ }^{206} \mathrm{~Pb} /{ }^{204} \mathrm{~Pb}$ slope is 8190 with $r^{2}=0.914$. The ${ }^{207} \mathrm{~Pb} /{ }^{204} \mathrm{~Pb}-{ }^{206} \mathrm{~Pb} /{ }^{204} \mathrm{~Pb}$ slope from Hanan et al. (1986) (0.1210, $\left.r^{2}=0.982, n=18\right)$ gives a $P b-P b$ age for this ridge segment of $1.97 \times 10^{9} y$, and second stage $\mu$ ranges from $8.18-12.8$. The ${ }^{208} \mathrm{~Pb} /{ }^{204} \mathrm{~Pb}$ slope $\left(=1.198, r^{2}=0.993\right)$ implies $\kappa_{2}=4.18$ (constant $\kappa$ mode 1 ). These parameters, used in conjunction with the 
He-Pb isotope correlation and two-stage fractionation model imply initial ${ }^{3} \mathrm{He} /{ }^{4} \mathrm{He}$ of $\sim 12.6 \mathrm{R}_{\mathrm{A}}$ for this subsystem (see chapter 6 ).

The $\mathrm{He}-\mathrm{Pb}$ isotope data for the St. Helena segment does not fall on a single binary mixing curve. Relative to the hotspot source-ridge sink model, the He-Pb results along this ridge segment suggest that the St. Helena end-member has a higher ${ }^{3} \mathrm{He} /{ }^{204} \mathrm{~Pb}$ ratio (by a factor of $3-10$ ) and lower ${ }^{3} \mathrm{He} /{ }^{4} \mathrm{He}$ ratio than depleted MORB mantle (Fig. 5.8-5.10). These parameters offer insight into some aspects of the hotspot - ridge interaction. For example, prior to mixing with St. Helena material, the depleted mantle asthenosphere may have been "mined" of some fraction of its He. During such a process, the end-members retain their ${ }^{3} \mathrm{He} /{ }^{4} \mathrm{He}$ and ${ }^{206} \mathrm{~Pb} /{ }^{204} \mathrm{~Pb}$ ratios, but different $\mathrm{He} / \mathrm{Pb}$ mixing ratios occur. The observed trends on Fig. 5.8-5.10 for the St. Helena segment are consistent in a general way with the mining and mixing hypothesis, but have the added requirement of variable ${ }^{3} \mathrm{He} /{ }^{204} \mathrm{~Pb}$ mixing ratios. An alternative is that the source materials may be melted to different extents prior to mixing. For example, a small amount of melting of the St. Helena source might lead to elevated $\mathrm{He} / \mathrm{Pb}$ in that end-member prior to mixing with the depleted mantle material.

To better constrain these effects within the framework of He concentrations, some of the MORB glasses were analyzed for total [He] by fusion of large (2-4 mm) glass shards. For the Circe segment, more radiogenic He signatures are associated with decreasing He content. The relationship for the St. Helena segment is much weaker. ${ }^{4} \mathrm{He} /{ }^{3} \mathrm{He} v \mathrm{~s}$. $1 /\left[{ }^{3} \mathrm{He}\right]$ (Fig. 5.11) shows that the three samples analyzed from the Circe segment are highly correlated $\left(r^{2}=0.998\right.$, and ${ }^{3} \mathrm{He} /{ }^{4} \mathrm{He}$ 
Figure 5.11. Total fusion ${ }^{4} \mathrm{He} /{ }^{3} \mathrm{He}$ vs. $1 /\left[{ }^{3} \mathrm{He}\right]$ for South Atlanic MORB glasses. 


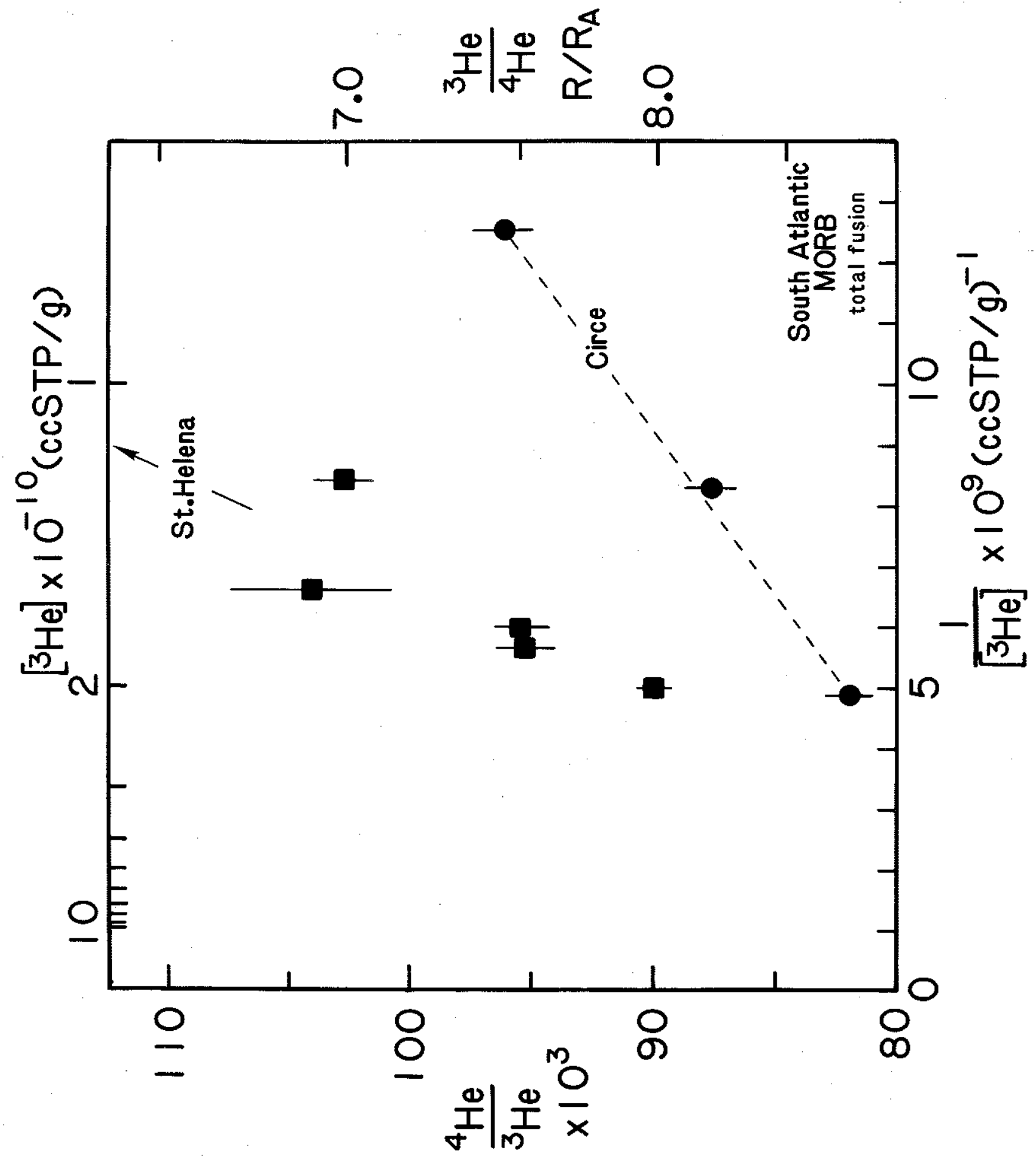


intercept $=10 \mathrm{R}_{\mathrm{A}}$ at zero $\left.[\mathrm{He}]\right)$. The Circe results are consistent with an earlier fractionation of $(U+T h) /{ }^{3} \mathrm{He}$ from a common reservoir. The linear ${ }^{4} \mathrm{He} /{ }^{3} \mathrm{He}-1 /\left[{ }^{3} \mathrm{He}\right]$ would suggest that in the episodic model, the time-integrated history of $\left(U_{+} T h\right) /{ }^{3} \mathrm{He}$ for each sample may be controlled by the extent of He loss. Binary mixing of a MORB end-member with a radiogenic He component also produces straight lines on this diagram and therefore cannot be eliminated as a possibility. Samples from the St. Helena segment also show (although weakly) that as ${ }^{3} \mathrm{He}$ content decreases more radiogenic He signatures are observed. Sample 18D-1 is an exception; it apparently suffered recent loss of He relative to the other samples along this segment of the ridge, possibly associated with its eruption. The $\mathrm{He}-\mathrm{Pb}$ isotope results for the St. Helena segment require ${ }^{3} \mathrm{He} /{ }^{204} \mathrm{~Pb}$ ratios in the St. Helena end-member which are higher than in the depleted MORB end-member (Fig. 5.8-5.10). However, the hotspot He signature becomes increasingly detectable when lower He concentrations are measured in the erupted products (Fig. 5.11). If the higher $\mathrm{He} / \mathrm{Pb}$ in the St. Helena end-member is due to higher He contents, then its He signature is more readily detected because either 1) prior to mixing, He has been lost from the MORB source region or 2) the depleted end-member is solid and the St. Helena material is an incipient melt. Alternatively, the higher $\mathrm{He} / \mathrm{Pb}$ in St. Helena material is due to lower $\mathrm{Pb}$ contents in the St. Helena source. It is not possible to distinguish which effect is dominant from the He and $\mathrm{Pb}$ data alone. The mining hypothesis is attractive because it is consistent with the low ${ }^{3} \mathrm{He} /{ }^{4} \mathrm{He}$ and $\mathrm{He}$ contents observed in seamount alkali basalts near the East Pacific Rise, as discussed in chapter 4. 


\subsubsection{He and $\mathrm{Pb}$ Isotopic Variations in St. Helena Lavas}

Results for He isotopic compositions measured by in vacuo crushing of phenocrysts separated from St. Helena rocks are given in Table 5.4, along with $\mathrm{Pb}$ isotope analyses for whole rock powders prepared from the same samples. The $\mathrm{Pb}$ isotope results are shown in Fig. 5.12. Note that one sample, CEl8 (an ankaramite), has lower $\mathrm{Pb}$ isotope ratios than previously measured at St. Helena by Sun (1980). Its $\mathrm{Pb}$ isotope composition is more radiogenic than that reported for one sample by Cohen and O'Nions $(1982 b)$, and it lies along the trend defined by the other analyses. The ${ }^{207} \mathrm{~Pb} /{ }^{204} \mathrm{~Pb}-{ }^{206} \mathrm{~Pb} /{ }^{204} \mathrm{~Pb}$ slope gives a secondary isochron "age" for the St. Helena source of $1.62 \mathrm{Ga}\left(r^{2}=0.73, n=19 ;\right.$ all data $)$. From the ${ }^{208} \mathrm{~Pb} /{ }^{204} \mathrm{~Pb}-{ }^{206} \mathrm{~Pb} /{ }^{204} \mathrm{~Pb}$ slope, $\kappa_{2}$ is 2.3 (constant second-stage $\kappa$ modell.

Helium was extracted by crushing different phenocryst phases separated from three basalts (CE IA, CE 13 and CE 18). These samples represent different eruptive episodes at the island (see Fig. 5.3). The results show a restricted range in He isotope composition, with ${ }^{3} \mathrm{He} /{ }^{4} \mathrm{He} \sim 5.1-5.8 \mathrm{R}_{\mathrm{A}}\left({ }^{4} \mathrm{He} /{ }^{3} \mathrm{He} \sim 120-155 \times 10^{3}\right)$. Three different phenocryst types (olivine and brown pyroxene in CE $1 A$, brown and green pyroxenes in CE 18, brown pyroxene in CE 13) were analyzed. Baker (1969) has described the pyroxenes in these types of St. Helena rocks to be titanaugite and aegirine-augite, respectively. The brown pyroxene from CE.13 (a trachybasalt representing a later stage of evolution) has a much lower He content than the same phase in the other samples, and the measured He isotope ratio is much less certain $\left(2.8 \pm 2.4(2 \sigma) R_{A}\right)$. 


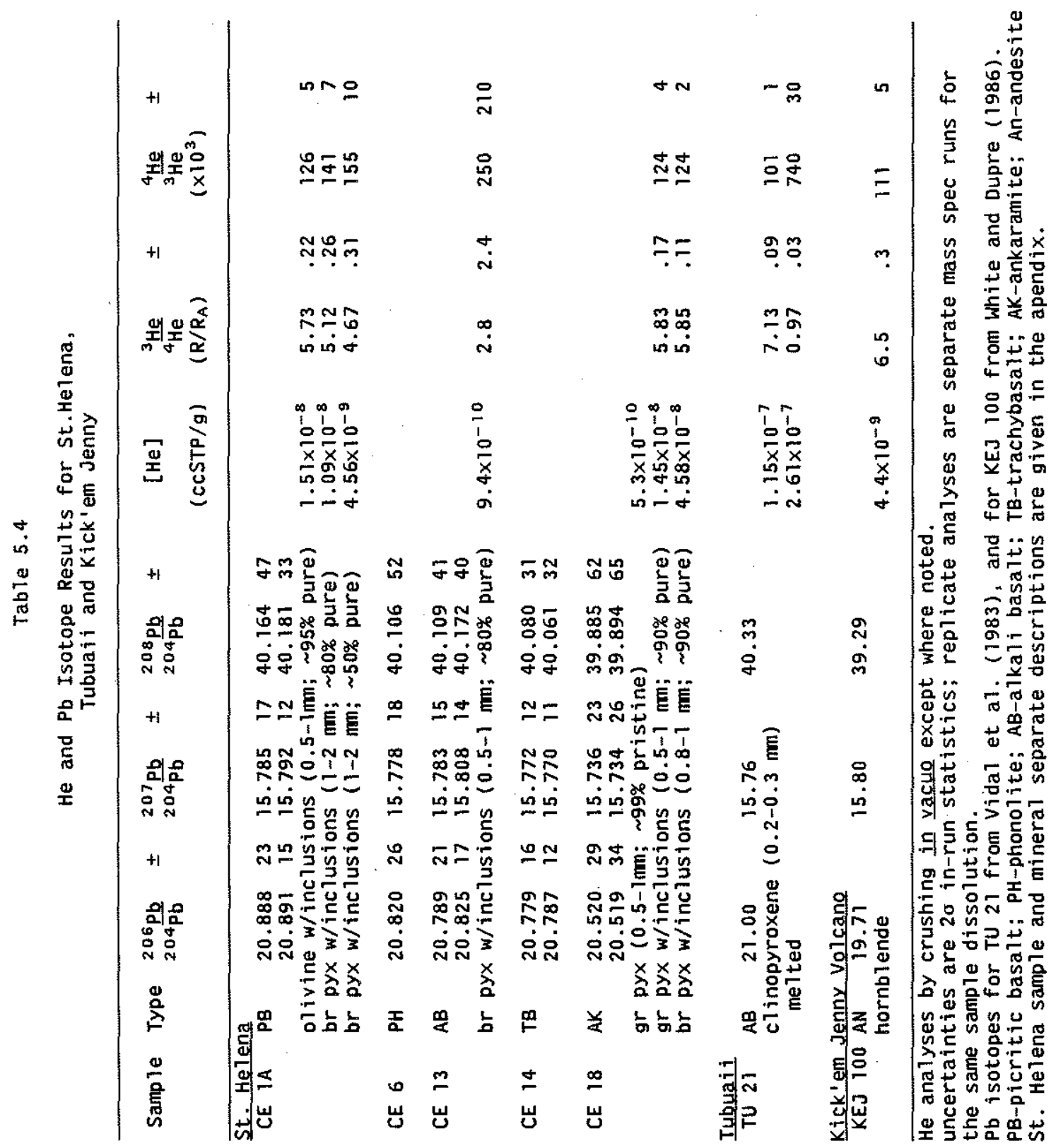


Figure $5.12{ }^{208} \mathrm{~Pb} /{ }^{204} \mathrm{~Pb}$ and ${ }^{207} \mathrm{~Pb} /{ }^{204} \mathrm{~Pb}$ vs. ${ }^{206} \mathrm{~Pb} /{ }^{204} \mathrm{~Pb}$ for St. Helena samples analyzed in this study. Also shown are data from Sun (1980) (open symbols) and Cohen and O'Nions (1982b) (half-filled symbols). Line is the northern hemisphere reference line of Hart (1984) (1.77 Ga) for ${ }^{207} \mathrm{~Pb} / 204 \mathrm{~Pb}$ Vs. ${ }^{206} \mathrm{~Pb} /{ }^{204} \mathrm{~Pb}$ in MORB and OIB, and for $T h / U=4.0$ for ${ }^{208} \mathrm{~Pb} /{ }^{204} \mathrm{~Pb}$. $\Lambda$, basalts, $\mathbf{n}$ trachybasalts and trachytes, $\bullet$, phonolites. 


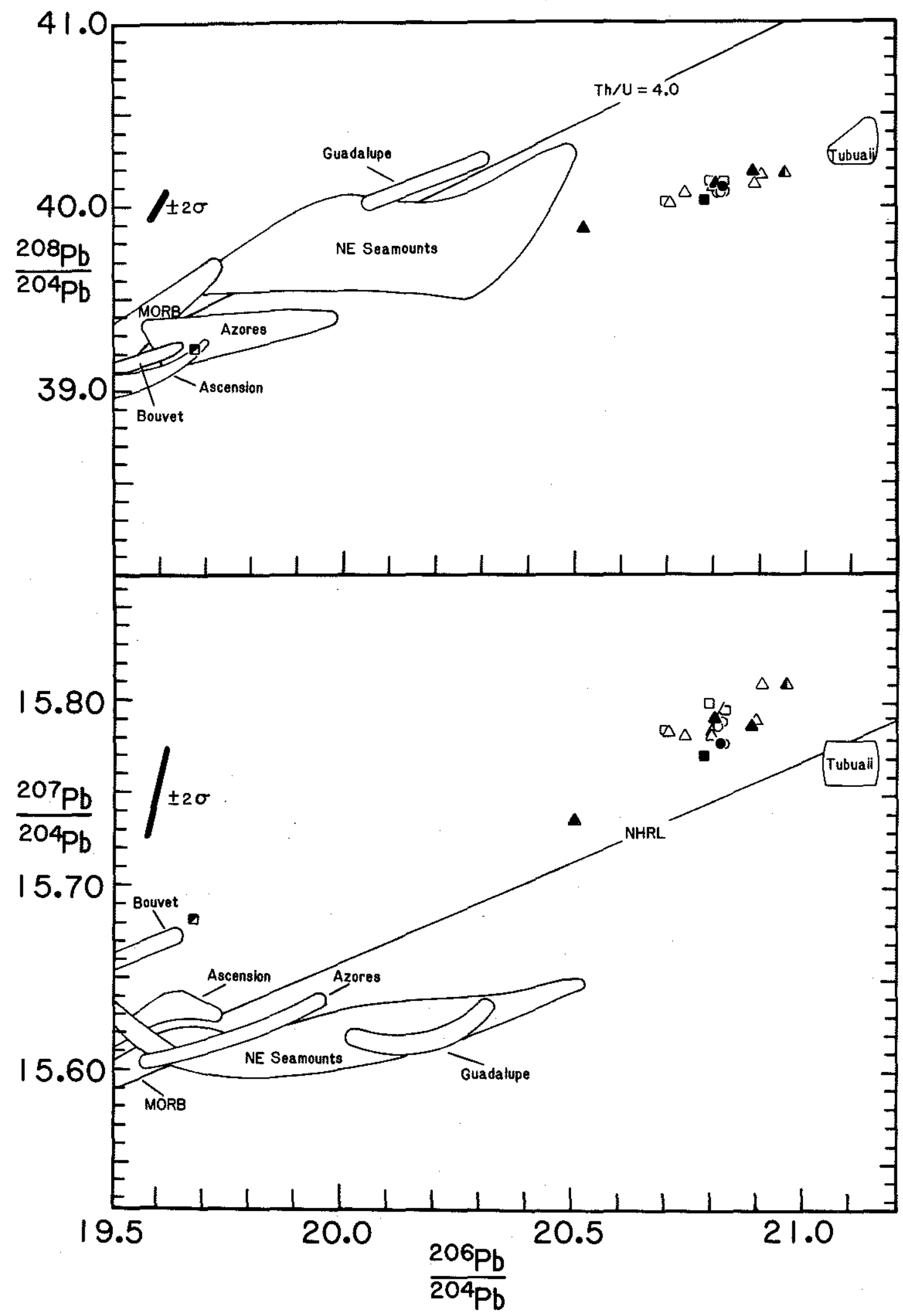


CE $1 A$ and CE 18 are from lower stratigraphic sections of the island where outcrops are probably exposed by recent erosion. These samples should not contain appreciable cosmogenic He. In addition, crushing of olivine does not appear to release significant amounts of a cosmogenic component when it is present (Kurz, 1986). In CE $1 A$ and CE 18, when ${ }^{3}$ He contents are greater than about $1 \times 10^{-13} \mathrm{cCSTP} / \mathrm{g}$ the analyzed phases have He isotope ratios which are analytically indistinguishable $\left(\sim 5.8 \mathrm{R}_{\mathrm{A}}\right)$. This is evidence that ${ }^{3} \mathrm{He} /{ }^{4} \mathrm{He}$ extracted by crushing silicate phases of low $U$ and Th contents can provide a reliable estimate of the inherited ratio in older $\left(\sim 10^{6}-10^{7} y\right)$ rocks. Crushing in vacuo should extract He primarily from fluid inclusions. ${ }^{4} \mathrm{He} /{ }^{3} \mathrm{He}$ vs. $1 /\left[{ }^{3} \mathrm{He}\right]$ (Fig. 5.13) provides additional information on the extent to which the crushing results reflect inherited ratios. When ${ }^{3} \mathrm{He}$ concentrations greater than $1 \times 10^{-13} \mathrm{cCSTP} / \mathrm{g}$ are measured, the inherited ${ }^{3} \mathrm{He} /{ }^{4} \mathrm{He}$ appears to be recovered for low $\left(U_{+} T h\right)$ phases of this age $\left(\sim 10^{7} y\right)$. Olivine in CE TA (a picritic basalt from the lower main shield) and brown and green pyroxenes in CE 18 (an ankaramite from lower stratigraphic levels of the northest of the island) all have ${ }^{3} \mathrm{He} /{ }^{4} \mathrm{He}$ $\simeq 5.8 \mathrm{R}_{\mathrm{A}}$. Samples with ${ }^{3} \mathrm{He}$ contents less than $1 \times 10^{-13} \mathrm{ccSTP} / \mathrm{g}$ show progressively higher ${ }^{4} \mathrm{He} /{ }^{3} \mathrm{He}$ when crushed in vacuo, due to an increased dilution with radiogenic $\mathrm{He}$. This increase in ${ }^{4} \mathrm{He} /{ }^{3} \mathrm{He}$ may be related to dilution with either post-eruptive or pre-eruptive (magmatic) radiogenic He. Temporal evolution of He isotope signatures in oceanic islands have been documented for Haleakala and Mauna Loa (Kurz et a1., 1987b). The early stages of mantle plume influence at those Hawaitan volcanoes ( $i . e$, the presence of a component of relatively 
Figure. $5.13{ }^{4} \mathrm{He} /{ }^{3} \mathrm{He}$ vs. $1 /\left[{ }^{3} \mathrm{He}\right]$ released by in vacuo crushing of phenocrysts from St. Helena basalts. 


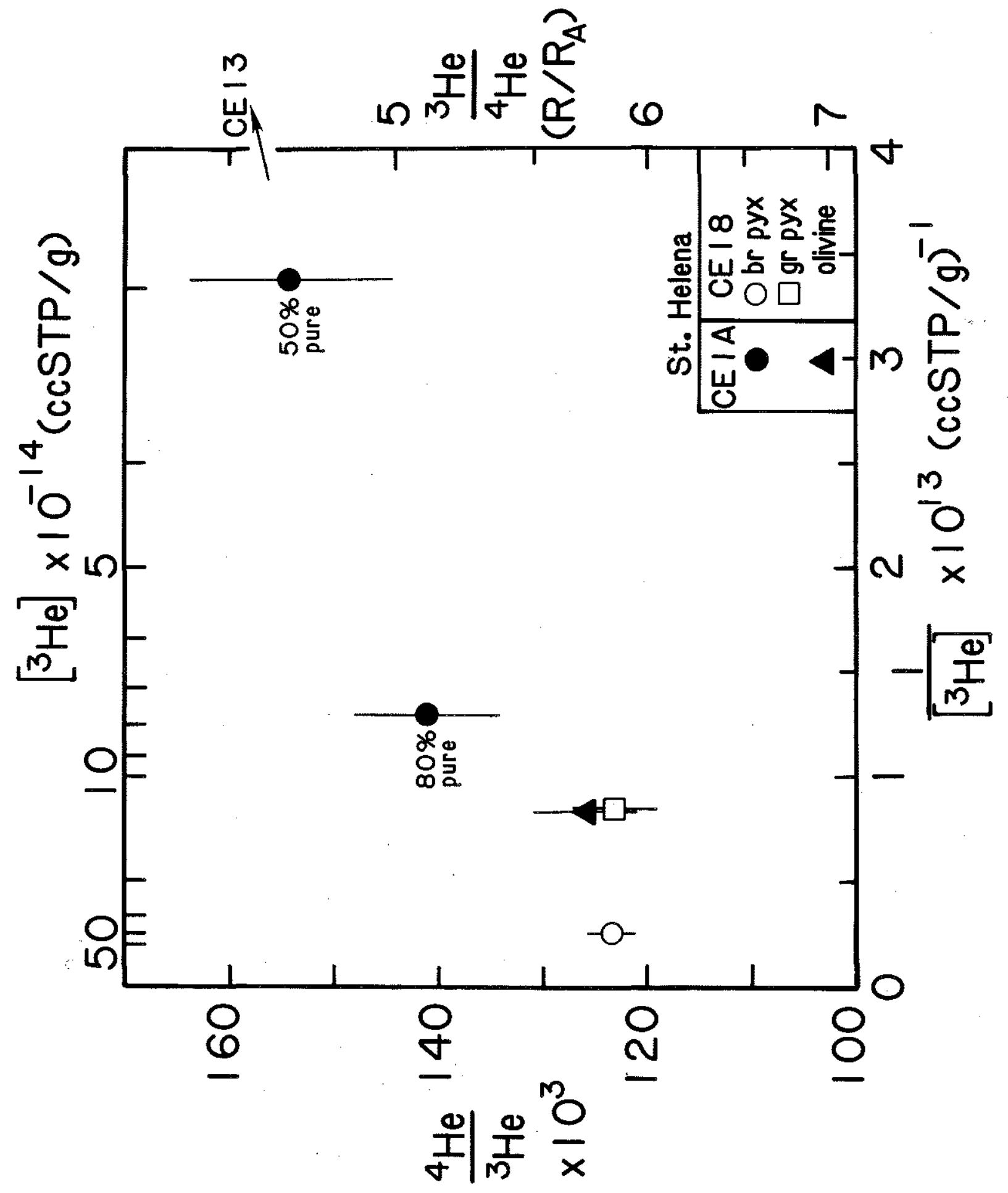


undegassed mantle material as inferred from the high ${ }^{3} \mathrm{He} /{ }^{4} \mathrm{He}$ ) is later followed by a relaxation toward MORB signatures, probably as a result of 1 ithospheric contamination. ${ }^{3} \mathrm{He} /{ }^{4} \mathrm{He}$ measured at St. Helena is only slightly lower than MORB values. Perhaps a temporal evolution toward MORB values applies at St. Helena as well, but this question cannot be addressed with the limited data reported here. The present results may in part reflect a temporal signature on the inherited ${ }^{3} \mathrm{He} /{ }^{4} \mathrm{He}$, since the later-extrusive rock (e.g. CE 13) appears to have much lower [He] in the same phase (pyroxene) analyzed from the earlier volcanics (CE IA and CE 18).

$U$ and Th concentrations have not been determined in these phases, a necessary requirement before a He budget can properly be made by melting the crushed residues. The $U$ content in the whole rocks can be crudely estimated from measured $K_{2} O$ assuming $K / U=1.3 \times 10^{4}$ (Jochum et al., 1983). The respective $U$ contents estimated in this way are $\sim 0.5,0.7$ and $1 \mathrm{ppm}$, respectively for CE $1 \mathrm{~A}, \mathrm{CE} 13$ and CE 18 . These values are typical of alkalic ocean island basalts. It appears that contamination by post-eruptive radiogenic $\mathrm{He}$ is the most reasonable explanation for the lower ${ }^{3} \mathrm{He} /{ }^{4} \mathrm{He}$ in samples with lower $\left[{ }^{3} \mathrm{He}\right]$.

\subsubsection{He Isotopes in Other Phenocrysts}

One sample from the island of Tubuai $i$ (which has similar $\mathrm{Pb}$ isotope compositions to St. Helena; Vidal et al., 1983) was also analyzed for He (TU 21, Table 5.3). ${ }^{3} \mathrm{He} /{ }^{4} \mathrm{He}$ extracted by crushing $\mathrm{clinopyroxene}$ phenocrysts from this sample (crushed $[\mathrm{He}]=1.2 \times 10^{-7} \mathrm{cCSTP} / \mathrm{g}$, $\left.{ }^{3} \mathrm{He} /{ }^{4} \mathrm{He}=7.1 \mathrm{R}_{\mathrm{A}}\right)$ is slightly higher than ${ }^{3} \mathrm{He} /{ }^{4} \mathrm{He}$ for St. Helena, but less than typical MORB values. The powder remaining from 
this sample was melted, yielding ${ }^{3} \mathrm{He} /{ }^{4} \mathrm{He}=0.97 \mathrm{R}_{\mathrm{A}}$ and $[\mathrm{He}]=$ $2.6 \times 10^{-7}$. The lava flow from which TU 21 was sampled is estimated to be 6.5-10 m.y. old (Vidal et al., 1983). If the He isotope disequilibrium in this clinopyroxene is the result of closed system radiogenic ingrowth it requires a $U$ content of $110-160 \mathrm{ppb}$ (for $T h / U=3$, calculated from eq. 3.3 and 3.4 ), somewhat high to be characteristic of this mineral phase. The distribution coefficient for $U$ in clinopyroxene ranges from .002-0.03 (Seitz, 1973; Benjamin et al., 1980). Therefore the [U] in clinopyroxene crystallizing from a melt with $\sim 1 \mathrm{ppm} U(a$ representative value) might be as high as $\sim 30 \mathrm{ppb}$ (an upper limit), insufficient to support the measured [He] in TU 21. One might argue that most of the $U$ and $T h$ in these silicate phases resides in melt inclusions. Considering that the radiogenic ${ }^{3} \mathrm{He} /{ }^{4} \mathrm{He}$ production ratio is $\sim .01 \mathrm{R}_{\mathrm{A}}$, and given the relative constancy of ${ }^{3} \mathrm{He} /{ }^{4} \mathrm{He}$ measured by crushing phases of similar, low $\left(U_{+} T h\right)$ content at St. Helena (and of similar age to TU 21), crushing does not appear to extract a large amount of ingrown He from olivine or pyroxene samples ranging in age up to $\sim 10^{7} \mathrm{y}$ when ${ }^{3} \mathrm{He}$ is extracted at greater than the $10^{-13} \mathrm{cCSTP} / \mathrm{g}$ level. Of course the ${ }^{3} \mathrm{He} /{ }^{4} \mathrm{He}$ released by crushing must be regarded as a minimum in such old samples, but the relatively narrow range measured at St. Helena suggests that the inherited component is recoverable. A reasonable explanation for the measured ${ }^{3} \mathrm{He} /{ }^{4} \mathrm{He}$ and [He] of the dissolved phase He (extracted by melting) in the TU 21 clinopyroxene appears to be $\alpha$-particle implantation from the surrounding rock matrix after eruption. This effect increases dramatically with decreasing grain size. For example, spherical crystals 
$0.50 \mathrm{~mm}$ and $0.25 \mathrm{~mm}$ in diameter, surrounded by a matrix with [U] $=1 \mathrm{ppm}$ can witness potential implantations of $\sim 1.7 \times 10^{-7} \mathrm{CCSTP} / \mathrm{g}$ and $\sim 3.6 \times 10^{-7}$ cCSTP/g of ${ }^{4} \mathrm{He}$, respectively, in $10^{7}$ y (assuming an $\alpha$-stopping distance of $25 \mu \mathrm{m}$ and a geometric efficiency factor of 25\%). Kurz (1986) observed depressed ${ }^{3} \mathrm{He} /{ }^{4} \mathrm{He}$ at the lowest temperature step during stepwise heating experiments on olivine powders from Haleakala. He estimated that implantation of $\sim 1 \%$ of the radiogenic He produced in the surrounding matrix was sufficient to produce the observed lowering. The clinopyroxene from TU 21 released $2.6 \times 10^{-7} \mathrm{cCSTP} / \mathrm{g}$ when melted, of which $\sim 85 \%$ is radiogenic given the isotope disequilibrium observed. The clinopyroxene in TU 21 is relatively fine-grained, typically $250 \mu \mathrm{m}$ in largest dimension. Thus, the melted results in this sample are consistent with implantation of about $15 \%$ of the radiogenic He produced in a surrounding lava with 1 ppm U.

Hornblende separated from KEJ 100, an andesite erupted at the submarine volcano Kick'em Jenny in the Lesser Antilles island arc, was also analyzed for He isotope composition (Table 5.4). $\mathrm{Pb}, \mathrm{Sr}$ and $\mathrm{Nd}$ isotope results for this sample are presented by White and Dupré (1986). ${ }^{3} \mathrm{He} /{ }^{4} \mathrm{He}$ in this sample is $6.5 \pm 0.3 \mathrm{R}_{\mathrm{A}}(2 \sigma)\left({ }^{206} \mathrm{~Pb} /{ }^{204} \mathrm{~Pb}=\right.$ $\left.19.71,{ }^{87} \mathrm{Sr} /{ }^{86} \mathrm{Sr}=0.7058,{ }^{143} \mathrm{Nd} / /^{144} \mathrm{Nd}=0.51278\right)$. This sample is presently the only island arc volcanic rock with paired analyses for $\mathrm{He}$ and $\mathrm{Pb}$ isotopes. ${ }^{3} \mathrm{He} /{ }^{4} \mathrm{He}$ at subduction zones is often lower than typical MORB values (Crajg et al., 1978; Poreda et al., 1985; Trull et al., 1987). The relatively $10{ }^{3} \mathrm{He} /{ }^{4} \mathrm{He}$ in $\mathrm{KEJ} 100$ is consistent with the interpretation of White and Dupré (1986) that the radiogenic $\mathrm{Pb}$ and 
Sr isotope signatures in Lesser Antilles volcanics reflect contamination by a small amount ( $3 \%$ ) of sediment in the source region.

\subsection{Summary}

In summary, $\mathrm{He}$ and $\mathrm{Pb}$ isotopic results from both the ridge segment opposite the island of St. Helena and in lavas from the island itself are consistent with ${ }^{3} \mathrm{He} /{ }^{4} \mathrm{He}$ less than typical MORB values for the HIMU component. This end-member appears to have ${ }^{3} \mathrm{He} /{ }^{4} \mathrm{He}$ near $6 \mathrm{R}_{\mathrm{A}}$. The linear $\mathrm{He}-\mathrm{Pb}$ isotope trends along the $2-12^{\circ} \mathrm{S}$ ridge segment may reflect mixing with Circe hotspot material of unknown isotopic composition which has ${ }^{3} \mathrm{He} /{ }^{204} \mathrm{~Pb}$ similar to depleted MORB mantle. It may also be explained by coupled temporal evolution of $\mathrm{He}$ and $\mathrm{Pb}$ isotopes in a subunit of the depleted mantle. 


\section{CHAPTER 6}

TERRESTRIAL HELIUM-LEAD ISOTOPIC EVOLUTION 


\subsection{Introduction}

Chapter 3 applied He isotope systematics to the geochronology of some young $\left(10^{3}-10^{6} y\right)$ alkali basalts, demonstrating the utility of He isotope measurements for the study of volcanic evolution on a short time scale in non-zero age rocks. Chapter 4 showed that in certain cases systematic differences in He isotope compositions between associated tholeites and alkali basalts, and between primitive and differentiated alkali basalts might be used to infer time scales of magmatic processes. The $\mathrm{Pb}$ isotope compositions of these alkali basalts imply that the mantle source regions have existed for long time periods $\left(10^{8}-10^{9}\right.$ y) with much higher $U, T h / P b$ than the depleted MORB mantle. Higher $\left(U_{+} T h\right) / H e$ ratios may also be characteristic of the alkali basalt source, but the processes accompanying the magma generation beneath young lithosphere may perturb simple $\mathrm{He}-\mathrm{Pb}$ relationships in the underlying mantle. Linear correlations between radiogenic $\mathrm{He}$ and $\mathrm{Pb}$ isotope signatures in some MORB from the South Atlantic, discussed in chapter 5, may imply coupled evolution for long time scales $\left(10^{8}-10^{9} y\right)$ in the mantle source regions. Other $\mathrm{He}-\mathrm{Pb}$ isotope relationships may result from mixing between long-term decoupled sources. In this chapter I explore the implications of coupled He and $\mathrm{Pb}$ isotope variations within the Earth's interior for the temporal history of $(\mathrm{U}+\mathrm{Th}) / \mathrm{He}, \mathrm{U} / \mathrm{Pb}$ and $\mathrm{Th} / \mathrm{Pb}$ and for convective mixing in the mantle source regions of some mid-ocean ridge and ocean island basalts. 


\subsection{The Closed System Approximation for Terrestrial He-Pb Isotope}

\section{Evolution}

The closed-system approximation for $\mathrm{He}$ and $\mathrm{Pb}$ isotope evolution is discussed here as a departure point for the development of more realistic multi-stage models of $\left(U_{+} T h\right) / H e, U / P b$ and $\mathrm{Th} / \mathrm{Pb}$ fractionation. Fig. 6.1 shows paired analyses plotted in the ${ }^{4} \mathrm{He} /{ }^{3} \mathrm{He}-{ }^{206} \mathrm{~Pb} /{ }^{204} \mathrm{~Pb}$ diagram for South Atlantic MORB, St. Helena and Tubuai (chapter 5), Shimada seamount (chapter 4), East African xenoliths (Cohen et al., 1984; Porcelli et al., 1986), various oceanic volcanics (Loihi seamount from Kurz et al., 1983 and Staudigel et a1., 1984; Reykjanes Ridge from Sun et al., 1975 and Poreda et al., 1986), and the range of fields for other islands (from Kurz et al., 1982a, Rison and Craig, 1983 and Sun, 1980). Also shown are lines for closed system planetary evolution assuming a primordial ${ }^{3} \mathrm{He} /{ }^{4} \mathrm{He}=100 \mathrm{R},{ }^{206} \mathrm{~Pb} /{ }^{204} \mathrm{~Pb}=9.307$ (Tatsumoto et al., 1973), $\mu=8.4$ and $\kappa=3.80$ for the "bulk earth" (Zindler and Hart, 1986a). Evolution lines for a fixed ${ }^{204} \mathrm{~Pb} /{ }^{3} \mathrm{He}$ are shown on this diagram. For chondritic $U \sim 20 \mathrm{ppb}$ (Zindler and Hart, 1986a) the ${ }^{204} \mathrm{~Pb} /{ }^{3} \mathrm{He}$ ratio allows an estimate of closed-system ${ }^{3} \mathrm{He}$ contents (given in caption to Fig. 6.1). Note that some islands (e.g., Loihi Samoa - Bouvet - Guadalupe - St. Helena or Loihi - Iceland - Tristan Shimada) may lie on approximately straight lines, and with different slopes than that for the best correlated South Atlantic MORB samples (from the Circe segment). In the following I discuss possible causes for linear relationships on this diagram using three simple models; 1) two-stage episodic evolution, 2) multi-stage or continuous evolution, and 
Figure $6.1{ }^{4} \mathrm{He} /{ }^{3} \mathrm{He}$ vs. ${ }^{206} \mathrm{~Pb} /{ }^{204} \mathrm{pb}$. Paired analyses from the literature include Loihi seamount (Kurz et al., 1983; Staudigel et al., 1984), Reykjanes Ridge (Sun et al., 1975; Poreda et al., 1986) and East African xenoliths (Cohen et al., 1984; Porcelli et al., 1986). Other paired analyses are from this study. The range of $\mathrm{He}$ and $\mathrm{Pb}$ isotope compositions at other islands are also shown (Kurz et al., 1982a; Sun, 1980). Lines on this diagram are for closed system "planetary evolution" assuming primordial ${ }^{3} \mathrm{He} /{ }^{4} \mathrm{He}=100 \mathrm{R}_{\mathrm{A}},{ }^{206} \mathrm{~Pb} /{ }^{20{ }^{4}} \mathrm{~Pb}=9.307, \mu=8.4$, $\kappa=3.80$. Numbers along evolution lines are $\rho / \mu=$ ${ }^{204} \mathrm{~Pb} /{ }^{3} \mathrm{He}$ (atom ratio). For $\rho / \mu=112,225,450$ and 1120, and a chondritic Earth ( $[U]=20 \mathrm{ppb}, \kappa=3.8$ ) the initial ${ }^{3} \mathrm{He}$ contents are $2 \times 10^{-9}, 10^{-9}, 5 \times 10^{-10}$ and $2 \times 10^{-10} \operatorname{cCSTP} / \mathrm{g}$, respectively. 


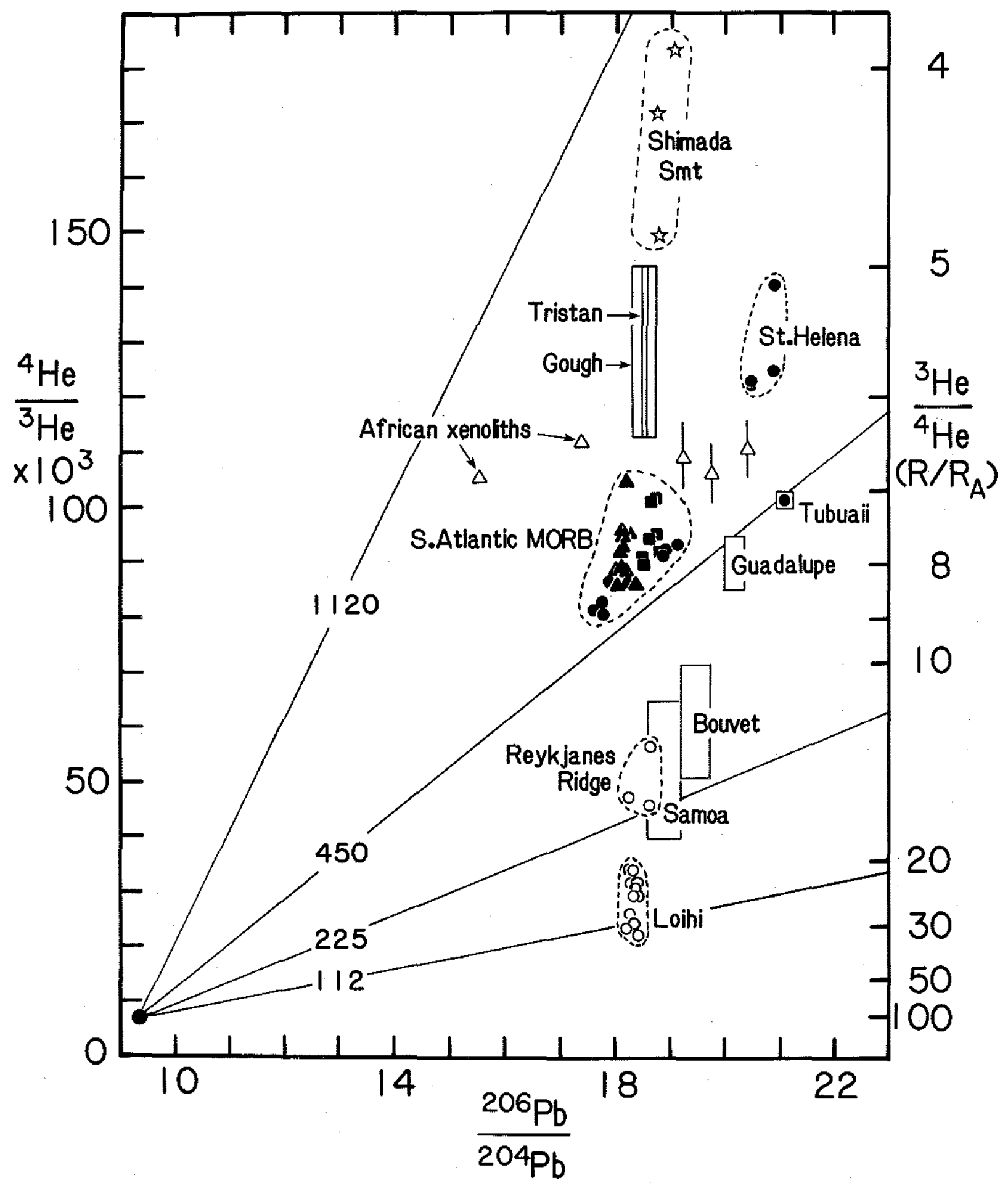


3) convective mixing (see Allègre et al,, 1979 for the original application of these ideas to the oceanic $\mathrm{Sr}-\mathrm{Nd}$ isotopic correlation). The results have implications for the interpretation of $\mathrm{He}$ and $\mathrm{Pb}$ isotope data for mantle-derived rocks.

In a system closed with respect to $U, T h, H e, P b$ and all intermediate daughters, equations 1.4-1.6 apply, and also

$$
\begin{gathered}
\left({ }^{4} \mathrm{He} /{ }^{3} \mathrm{He}\right)_{t}=\left({ }^{4} \mathrm{He} /{ }^{3} \mathrm{He}\right)_{0}+ \\
\rho\left[8\left(e^{\lambda_{B} T_{0}}-e^{\lambda_{B}}{ }^{t}\right)+(7 / 137.88)\left(e^{\lambda_{5} T_{0}}-e^{\lambda_{5} t}\right)+6 \kappa\left(e^{\lambda_{2} T_{0}-e^{\lambda_{2}} t}\right)\right]
\end{gathered}
$$

where $T_{0}$ is the age of the Earth $(4.55 \mathrm{Ga}$ ), $t=$ time (years ago), $p=$ ${ }^{238} \mathrm{U} /{ }^{3} \mathrm{He}$, and $\left({ }^{4} \mathrm{He} /{ }^{3} \mathrm{He}\right)_{0}$ is the primordial ratio.

\subsubsection{Two Stage Episodic Model}

Considering a two-stage episodic model for contemporaneous fractionation of $\rho$ and $\mu$ at time $t$, the slope on the ${ }^{4} \mathrm{He} /{ }^{3} \mathrm{He}-$ ${ }^{206} \mathrm{~Pb} /{ }^{204} \mathrm{~Pb}$ diagram $(S)$ is calculated from eq. $1.4-1.6$ and 6.1 , and is given by

$$
S=(\rho / \mu)\left\{8+\left[(7 / 137.88)\left(e^{\lambda_{s} t}-1\right)+6 \kappa\left(e^{\lambda_{2} t}-1\right)\right] /\left(e^{\lambda^{t}}-1\right)\right\}
$$

The slope of a sample array (e.g., lavas derived from an individual ocean island source) which has remained a closed system since $t$ depends on the ratio $\rho / \mu\left(=^{204} \mathrm{~Pb} /{ }^{3} \mathrm{He}\right)$ and $\kappa$. This slope is a straight line passing through the initial values of ${ }^{4} \mathrm{He} /{ }^{3} \mathrm{He}$ and ${ }^{206} \mathrm{~Pb} /{ }^{204} \mathrm{~Pb}$ (i.e., values at time $t$ ). In this two-stage model, the linear arrays for the $2-12^{\circ} \mathrm{S}$ ridge segment in the South Atlantic (chapter 5 ) on the He- $\mathrm{Pb}$ and $\mathrm{Pb}-\mathrm{Pb}$ isotope diagrams allow an estimate of "paleo" ${ }^{3} \mathrm{He} /{ }^{4} \mathrm{He}$ in the depleted MORB mantle below this region. If the ${ }^{207} \mathrm{~Pb} /{ }^{204} \mathrm{~Pb}-$ ${ }^{206} \mathrm{~Pb} /{ }^{204} \mathrm{~Pb}$ slope has age significance $\left(\mathrm{m}=0.1210, \mathrm{r}^{2}=0.982, \mathrm{n}=\right.$ 
18; calculated from data in Hanan et a1., 1986) this array gives second stage $\mu$ values ranging from 8.18 to 12.8 at $t_{1}=1.97 \times 10^{9}$ y ago $\left(\mu_{1}=8.10\right.$ and $\left.\left({ }^{206} \mathrm{~Pb} /{ }^{204} \mathrm{~Pb}\right)_{1}=14.713\right)$. For a model with constant $\kappa$ in the second stage, the slope of ${ }^{208} \mathrm{~Pb} /{ }^{204} \mathrm{~Pb}-$ ${ }^{206} \mathrm{~Pb} /{ }^{204} \mathrm{~Pb}\left(1.198 ; r^{2}=0.993\right)$ gives $\kappa_{2}=4.18$. From eq. (5.2) (where slope $S=8190$, intercept $b=-63140, r^{2}=0.914, n=9$ for the Circe ridge segment) $\rho / \mu={ }^{204} \mathrm{~Pb} /{ }^{3} \mathrm{He}=510$. Since $S$ is independently determined, $\left({ }^{4} \mathrm{He} /{ }^{3} \mathrm{He}\right)_{1}=\mathrm{S}\left({ }^{206} \mathrm{~Pb} /{ }^{204} \mathrm{~Pb}\right)_{1}+b$; thus $\left({ }^{4} \mathrm{He} /{ }^{3} \mathrm{He}\right)_{1}=57.3 \times 10^{3}\left(\mathrm{i} . \mathrm{e} .,{ }^{3} \mathrm{He} /{ }^{4} \mathrm{He}=12.6 \mathrm{R}_{\mathrm{A}}\right.$ at 1.97 Ga). This value is higher than that estimated from the slope of ${ }^{4} \mathrm{He} /{ }^{3} \mathrm{He}$ vs. $1 /\left[{ }^{3} \mathrm{He}\right]$ measured by total fusion of three samples from this ridge segment (initial ${ }^{3} \mathrm{He} /{ }^{4} \mathrm{He}=10 \mathrm{R}_{\mathrm{A}}$; Fig. 5.11). If differences in $\left[{ }^{3} \mathrm{He}\right]$ are the primary control on $\left(U_{+} T h\right) /{ }^{3} \mathrm{He}$ in the source, this discrepancy would suggest that MORB from the Circe segment may have lost He recently (e.g., prior to or during eruption). Note that on the ${ }^{4} \mathrm{He} /{ }^{3} \mathrm{He}-{ }^{206} \mathrm{~Pb} /{ }^{204} \mathrm{~Pb}$ evolution diagram (Fig. 6.1) the position of the Circe array falls approximately along a "planetary" evolution line with $\rho / \mu=510$. Although (at least) a two-stage episodic model is required by both the $\mathrm{He}$ and $\mathrm{Pb}$ isotope systematics $(\mathrm{Pb}$ isotope ratios plot to the right of the geochron on ${ }^{207} \mathrm{~Pb} /{ }^{204} \mathrm{~Pb}$ vs. $\left.{ }^{206} \mathrm{~Pb} /{ }^{204} \mathrm{~Pb}\right)$, the ${ }^{4} \mathrm{He} /{ }^{3} \mathrm{He}-{ }^{206} \mathrm{~Pb} /{ }^{204} \mathrm{~Pb}$ correlation suggests a coherent evolution of ${ }^{204} \mathrm{~Pb} /{ }^{3} \mathrm{He}$ for a long time period. In addition, the sample with the least radiogenic $\mathrm{Pb}$ from this ridge segment (D5-3A) plots very close, but just to the right of the $4.55 \mathrm{Ga}$ geochron, consistent with a time-integrated U/Pb which has increased only slightly during much of Earth's history. The $2 \mathrm{Ga}$ 
secondary $\mathrm{Pb}-\mathrm{Pb}$ isochron for the Circe ridge segment indicates that the system was disturbed for $U / P b$ (and probabiy for $(U+T h) /{ }^{3} H e$ ) at that time. If the episodic model applies, and the linear ${ }^{4} \mathrm{He} /{ }^{3} \mathrm{He}-$ ${ }^{206} \mathrm{~Pb} /{ }^{204} \mathrm{~Pb}-{ }^{207} \mathrm{~Pb} /{ }^{204} \mathrm{~Pb}-{ }^{208} \mathrm{~Pb} /{ }^{204} \mathrm{~Pb}$ correlations result from various extents of melt extraction, the accompanying fractionation of $(U+T h) /{ }^{3} \mathrm{He}, \mathrm{U} / \mathrm{Pb}$ and $\mathrm{Th} / \mathrm{Pb}$ during melt removal was very coherent. Alternatively, a process occurred which added variable amounts of $U_{+} T h$, but maintained constant ${ }^{204} \mathrm{~Pb} /{ }^{3} \mathrm{He}$.

Some MORBs from the Circe ridge segment have the least radiogenic ${ }^{87} \mathrm{Sr} /{ }^{86} \mathrm{Sr}$ measured in oceanic basalts $(\sim 0.7021$; Cole et al., 1985). The identification of ${ }^{129} \mathrm{Xe}$ anomalies in some MORB and its anti-correlation with ${ }^{87} \mathrm{Sr} /{ }^{86} \mathrm{Sr}$ and ${ }^{40} \mathrm{Ar} /{ }^{36} \mathrm{Ar}$ (Allegre et al., 1983) is evidence that some units of the depleted upper mantle have not been in communication with Earth's atmosphere (or have not seen significant contamination by materials which have been influenced by atmospheric components), for very long times $(\sim 4.4 \mathrm{Ga})$. Catastrophic early degassing of $X e$ from the mantle is the best explanation for the ${ }^{129} \mathrm{Xe}$ anomalies (since its parent nuclide ${ }^{129} \mathrm{I}$ is now extinct, having a half-life of 17 m.y.). Early degassing readily affects the $X e$ isotopic evolution of the residual mantle because production occurs on a time scale comparable to the outgassing event $\left(\sim 10^{7} \mathrm{y}\right)$. Changes in ${ }^{3} \mathrm{He} /{ }^{4} \mathrm{He}$ early in the Earth's history was dominated by ${ }^{4} \mathrm{He}$ production from ${ }^{235} \mathrm{U}$ decay and strongly dependent on $\left(U_{+} T h\right) /{ }^{3} \mathrm{He}$; these would occur over a longer time scale $\left(\sim 10^{8} \mathrm{y}\right)$. More importantly, any record of early changes in $\left(U_{+} T h\right) /{ }^{3}$ He is lost due to He escape from the upper atmosphere. Thus, while catastrophic degassing 
may have changed $(U+T h) /{ }^{3} \mathrm{He}$ dramatically, it is not resolvable by comparing He isotope compositions of the atmosphere and residual mantle. If the linear $\mathrm{He}-\mathrm{Pb}$ isotope correlations result from a continuous melt extraction process, then the continued degassing of the Earth's interior appears to have been mediated primarily by transport of molten material to the Earth's surface. The associated removal of $\mathrm{He}$ and $\mathrm{Pb}$ to exogenic geochemical cycles would produce coherent $\rho / \mu$ fractionation in the residual mantle.

For a set of systems (e.g., various ocean island sources) which have remained closed since their fractionation $t$ years ago from a common reservoir, the slope of the systems considered collectively $\left(S^{\prime}\right)$ will be $S^{\prime}=\left[\left({ }^{4} \mathrm{He} /{ }^{3} \mathrm{He}\right)_{\mathrm{A}}-\left({ }^{4} \mathrm{He} /{ }^{3} \mathrm{He}\right)_{\mathrm{B}}\right] /\left[\left({ }^{206} \mathrm{~Pb} / 20{ }^{4} \mathrm{~Pb}\right)_{\mathrm{A}}-\left({ }^{206} \mathrm{~Pb} /{ }^{204} \mathrm{~Pb}\right)_{\mathrm{B}}\right]$

where the subscripts denote the respective systems. Assuming constant $k_{2}$ for each system (a reasonable approximation given the relative constancy of Th/U in OIB) then $S^{\prime}=\left\{\left(\rho_{A}-\rho_{B}\right) /\left(\mu_{A}-\mu_{B}\right)\right\}\left\{8+\left[(7 / 137.88)\left(e^{\lambda} 5^{t}-1\right)+6 \kappa\left(e^{\lambda} 2^{t}-1\right)\right] /\left(e^{\lambda} B^{t}-1\right)\right\}$

These OIB will lie on a linear array for any time $t$ if $\left(\rho_{A}-\rho_{B}\right) /\left(\mu_{A}-\mu_{B}\right)=a / b$ is a constant $)$. Relative to the least fractionated system (i.e., a source with high ${ }^{3} \mathrm{He} /{ }^{4} \mathrm{He}$ such as that for Loihi), the various other systems lying on a line may have fractionated $\left({ }^{238} \mathrm{U} /{ }^{3} \mathrm{He}\right)$ in roughly constant proportion to $\left({ }^{238} \mathrm{U} /{ }^{204} \mathrm{~Pb}\right)$. In the two-stage episodic model this fractionation is robust with respect to its time of occurrence. For example, if the fractionation event occurred $\sim 1.8 \mathrm{Ga}$ ago (the "apparent isochron" for oceanic volcanics on the ${ }^{207} \mathrm{~Pb} /{ }^{204} \mathrm{~Pb}-{ }^{206} \mathrm{~Pb} /{ }^{204} \mathrm{~Pb}$ diagram), and $k \simeq 3$, then (from eq. 6.4) $a / b=$ (observed $\left.S^{\prime} / 13.98\right)=3098$; if it 
occurred recently $\left(t \simeq 10^{4} y\right), a / b=\left(S^{\prime} / 14.06\right)=3078$. A linear ${ }^{4} \mathrm{He} /{ }^{3} \mathrm{He}-{ }^{206} \mathrm{~Pb} /{ }^{204} \mathrm{~Pb}$ slope for some islands would merely reflect the temporal evolution of $\rho / \mu$, and would not be a strong function of time unless the $\left(U_{+} T h\right) / H e, U / P b$ and $T h / P b$ fractionation occurred before $\sim 2 \mathrm{Ga}$. As an example, a simple model illustrating the consequences of $\rho$ and $\mu$ fractionation at $1.8 \mathrm{Ga}$ in the source of the respective islands plotting along one possible array (St. Helena - Guadalupe Bouvet - Samoa - Loihil from a common "primary" reservoir is presented in Table 6.1 and Fig. 6.2. The purpose of this model is not to argue for a unique history of the various source reservoirs or that the specific parameters deduced from the model reflect precisely that history, but rather to demonstrate quantitatively some aspects of the $\mathrm{He}$ and $\mathrm{Pb}$ isotope evolution that would follow a coherent fractionation of $(\mathrm{U}+\mathrm{Th}) / \mathrm{He}, \mathrm{U} / \mathrm{Pb}$ and $\mathrm{Th} / \mathrm{Pb}$.

The episodic model steps are:

1) A primary reservoir with $\mu_{i}=8.40$ (see arguments in Zindler and Hart, 1986a for the choice of this value), $\left({ }^{3} \mathrm{He} /{ }^{4} \mathrm{He}\right)=100 \mathrm{R}_{\mathrm{A}}$ and $k=3.80$ evolves to $1.8 \mathrm{Ga}\left(t_{1}\right)$ as a closed system. At $t_{1}$, $\left({ }^{206} \mathrm{~Pb} /{ }^{204} \mathrm{~Pb}\right)=15.216$. As a reference reservoir, I assume that if this system remained closed until today it would evolve to ${ }^{3} \mathrm{He} /{ }^{4} \mathrm{He}=$ $50 R_{A}$, greater than the highest value measured at Loihi seamount ( 32 $\mathrm{R}_{\mathrm{A}}$; Kurz et a1., 1983). The primary reservor therefore has $\left({ }^{3} \mathrm{He} /{ }^{4} \mathrm{He}\right)=57.7 \mathrm{R}_{\mathrm{A}}$ at $1.8 \mathrm{Ga}$, and present day $\rho=391$. (Allegre et al. (1986a) have recently shown that $k \simeq 4.2$ may be more appropriate for the bulk earth. Results using this value are not 
Table 6.1

He-Pb Evolutionary Parameters for

Two-Stage Episodic Mode $1\left(T_{1}=1.8 \mathrm{Ga}\right)$

\begin{tabular}{lrrrrrr}
\hline Reservoir & $\begin{array}{c}\text { Time } \\
(\mathrm{Ga})\end{array}$ & $\mu$ & $\kappa$ & $\rho$ & $\begin{array}{r}{ }^{3} \mathrm{He} /{ }^{4} \mathrm{He} \\
\left(\mathrm{R} / \mathrm{R}_{\mathrm{A}}\right)\end{array}$ & ${ }^{206} \mathrm{~Pb} /{ }^{204} \mathrm{~Pb}$ \\
& 4.55 & & & & 100 & 9.307 \\
Bulk Earth & 1.80 & & & & 57.7 & 15.216 \\
& 0 & & 3.8 & 391 & 50.0 & 17.921 \\
Loihi & 0 & 10.04 & 3.0 & 2228 & 32.0 & 18.450 \\
Bouvet & 0 & 12.73 & 3.0 & 10561 & 12.0 & 19.317 \\
Guadalupe & 0 & 14.88 & 3.0 & 17222 & 8.0 & 20.009 \\
St. Helena & 0 & 17.03 & 3.0 & 23870 & 6.0 & 20.700 \\
& & & & & & \\
\hline
\end{tabular}


Figure 6.2 Two-stage fractionation model of $p / \mu$ outlined in the text. Numbered curves correspond to

\begin{tabular}{cccc} 
& $\rho_{2}$ & $\mu_{2}$ & $\kappa_{2}$ \\
\hline A & 23870 & 17.03 & 3.00 \\
B & 17222 & 14.88 & \\
C & 10561 & 12.73 & \\
D & 2228 & 10.04 &
\end{tabular}




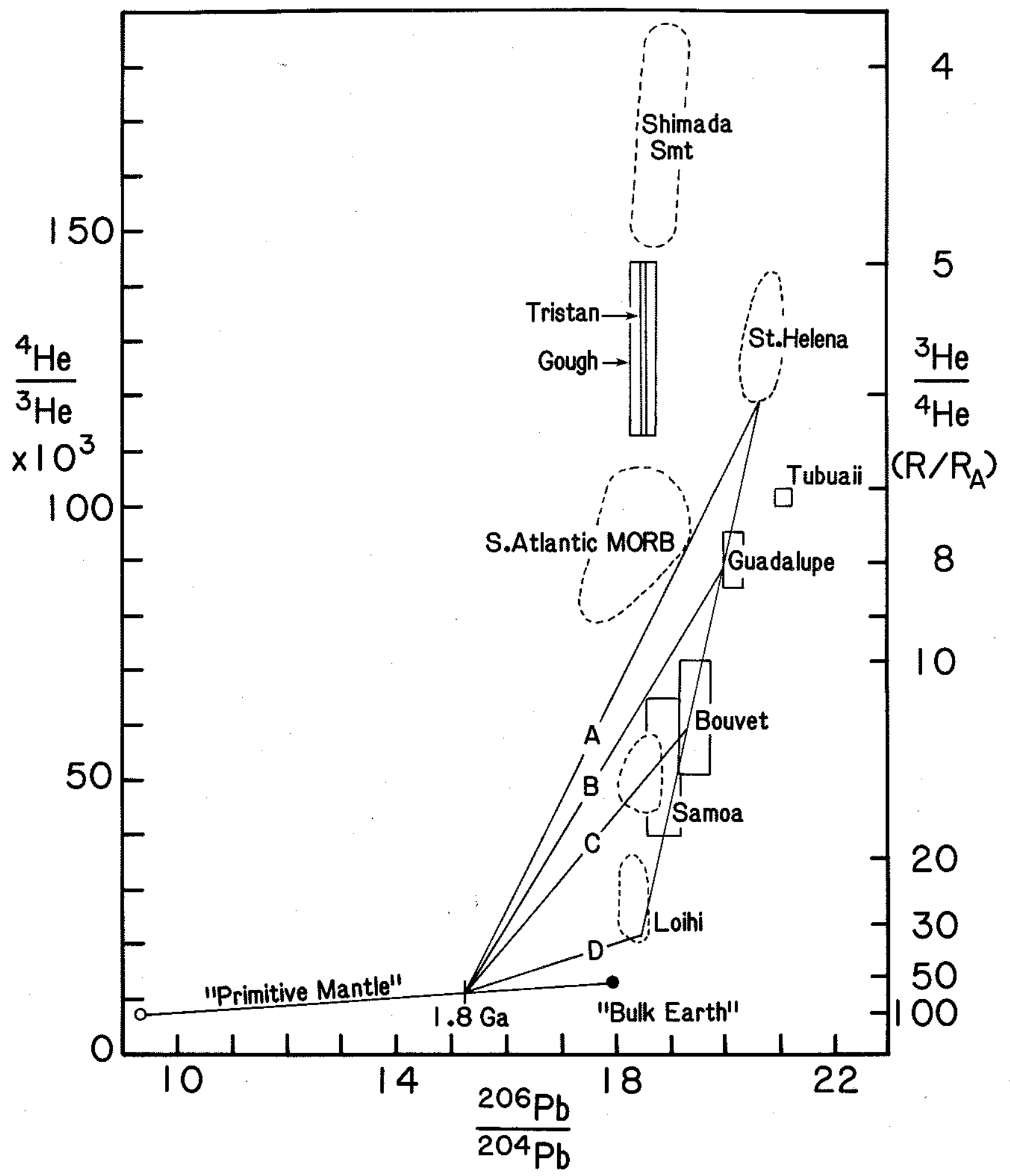


significantly different; for present day bulk earth of $50 R_{A}, \rho=379$ and ${ }^{3} \mathrm{He} /{ }^{4} \mathrm{He}$ at $1.8 \mathrm{Ga}$ would be $57.9 \mathrm{R}_{\mathrm{A}}$.)

2) From $1.8 \mathrm{Ga}$ to the present, various island source reservoirs evolve as independent, closed systems, with different $\rho_{2}, \mu_{2}$ and $\kappa_{2}$. A common $\kappa=3.00$ is assumed for this illustration. Thus, Loihi, with present day ${ }^{206} \mathrm{~Pb} /{ }^{204} \mathrm{~Pb}=18.45$ (sample KK18-8) and ${ }^{3} \mathrm{He} /{ }^{4} \mathrm{He}=32 \mathrm{R}_{\mathrm{A}}$ evolves with $\mu_{2}=10.04$ and $\rho_{2}=2228$. In contrast, St. Helena with present day ${ }^{206} \mathrm{~Pb} /{ }^{204} \mathrm{~Pb}=20.70$ and ${ }^{3} \mathrm{He} /{ }^{4} \mathrm{He}=6.0 \mathrm{R}_{\mathrm{A}}$ evolves with $\mu_{2}=17.03$ and $\rho_{2}=23870$. As discussed above, $\left(\rho_{S H}-\rho_{L O h_{h i}}\right) /\left(\mu_{S H}-\mu_{L O h_{H}}\right)=a / b=$ 3098. This array does not pass through the bulk earth value due to the imposed fractionation of $k$ in the model.

\subsubsection{Mixing}

Mixing of reservoirs with similar ${ }^{204} \mathrm{~Pb} /{ }^{3} \mathrm{He}$ ratios can of course produce a straight line on the ${ }^{4} \mathrm{He} /{ }^{3} \mathrm{He}-{ }^{206} \mathrm{~Pb} /{ }^{204} \mathrm{~Pb}$ diagram. If mixing produces approximate linear arrays for some islands (e.g., Loihi-Bouvet-Guadalupe-St. Helena), it requires that some mantle components which have evolved with different $\rho$ and $\mu$ (as is clear from the range of $\mathrm{He}$ and $\mathrm{Pb}$ isotopic compositions) have similar ${ }^{204} \mathrm{~Pb} /{ }^{3} \mathrm{He}$ ratios, or that fractionation has been achieved solely by modification of $U$ (and Th) contents. The selected group of islands mentioned above is clearly only part of the existing data set. Mixing is the most tenable explanation for the $\mathrm{He}-\mathrm{Pb}$ relationships for other locations, such as along the different ridge segments in the South Atlantic. 


\subsubsection{Multi-Episodic Evolution}

For multi-stage evolution where the time intervals between fractionation steps are short $(t<1 / \lambda)$, the following relationships apply (following Allègre et al., 1979)

$$
\begin{aligned}
& \left({ }^{4} \mathrm{He} /{ }^{3} \mathrm{He}\right)=\left({ }^{4} \mathrm{He} /{ }^{3} \mathrm{He}\right)_{0}+ \\
& \rho_{1}\left\{8 \lambda_{8}\left(T_{0}-T_{1}\right)+(7 / 137.88) \lambda_{5}\left(T_{0}-T_{1}\right)+6 \kappa_{1} \lambda_{2}\left(T_{0}-T_{1}\right)\right\}+\ldots \\
& \rho_{n}\left\{8 \lambda_{8}\left(T_{n-1}-T_{n}\right)+(7 / 137.88) \lambda_{5}\left(T_{n-1}-T_{n}\right)+6 \kappa_{n} \lambda_{2}\left(T_{n-1}-T_{n}\right)\right\}+ \\
& \rho_{n+1}\left\{8 \lambda_{8} T_{n}+(7 / 137.88) \lambda_{5} T_{n}+6 \kappa_{n+1} T_{n}\right\} \\
& \left({ }^{206} \mathrm{~Pb} / 204 \mathrm{~Pb}\right)=\left({ }^{206} \mathrm{~Pb} /{ }^{204} \mathrm{~Pb}\right)_{0}+\mu_{1} \lambda_{8}\left(T_{0}-T_{1}\right)+\ldots \\
& \mu_{n} \lambda_{8}\left(T_{n-1}-T_{n}\right)+\mu_{n+1} \lambda_{8} T_{n}
\end{aligned}
$$

Rearranging and grouping terms gives

$$
\begin{aligned}
& \Delta\left({ }^{4} \mathrm{He} /{ }^{3} \mathrm{He}\right)=\sum\left\{\rho_{\mathrm{i}+1}\left[8 \lambda_{8}+(7 / 137.88) \lambda_{5}+6 \kappa_{\mathrm{i}+1} \lambda_{2}\right]\right. \\
&-\left.\rho_{1}\left[8 \lambda_{8}+(7 / 137.88) \lambda_{5}+6 \kappa_{1} \lambda_{2}\right]\right\} T_{4} \\
& \Delta\left({ }^{206} \mathrm{~Pb} /{ }^{204} \mathrm{~Pb}\right)= \sum\left(\mu_{i+1}-\mu_{i}\right) \lambda_{8} \mathrm{~T}_{i}
\end{aligned}
$$

Assuming changes in $k$ are small, for any number of stages $(n)$ various systems will exhibit a straight line slope on the ${ }^{4} \mathrm{He} /{ }^{3} \mathrm{He}-$ ${ }^{206} \mathrm{~Pb} /{ }^{204} \mathrm{~Pb}$ diagram when $\left(\rho_{i+1}-\rho_{1}\right) /\left(\mu_{++1}-\mu_{i}\right)=c / d$ is a constant. As one example, if continuous evolution has produced the 1 inear $\mathrm{He}-\mathrm{Pb}$ array for the Circe ridge segment, then $(\mathrm{U} / \mathrm{He}) /(\mathrm{U} / \mathrm{Pb})$ has varied in a systematic mannner.

A collection of systems ultimately derived from a common reservoir by independent, multi-stage histories will lie on a straight line when $\left(c_{A}-c_{B}\right) /\left(d_{A}-d_{B}\right)$ is a constant, where subsripts denote respective systems. Various systems form a linear array when they have fractionated 
${ }^{238} \mathrm{U} /{ }^{3} \mathrm{He}$ and ${ }^{238} \mathrm{U} /{ }^{204} \mathrm{~Pb}$ in a coherent manner at each step of evolution. The requirement is that the relative fractionation of $p$ in one system compared to another is approximately a constant value times the relative fractionation of $\mu$ between the two systems. This type of fractionation would imply a common process in producing the He- $\mathrm{Pb}$ isotopic differences between different source reservoirs. One example of such a process is removal of $\mathrm{Pb}$ and He from the earth's interior to crustal and atmospheric cycles by melt generation and migration. Alternatively, introduction of nearly constant relative proportions of recycled materials into the respective source regions might occur, systematically increasing $\left(U_{+} T h\right) /{ }^{3} \mathrm{He}$ and ${ }^{238} \mathrm{U} /{ }^{204} \mathrm{~Pb}$. Linear correlation of ${ }^{4} \mathrm{He} /{ }^{3} \mathrm{He}-{ }^{206} \mathrm{~Pb} /{ }^{204} \mathrm{~Pb}$ also implies that $\mathrm{He}$ and $\mathrm{Pb}$ (and possibly other long-lived radiogenic systems) need not be decoupled in the deep Earth. However, generation of magmas with high $\left(U_{+} T h\right) / H e$ ratios by shallow level degassing (at uppermost mantle or crustal levels) may obscure these relationships.

${ }^{4} \mathrm{He} /{ }^{3} \mathrm{He}$ is shown against ${ }^{206} \mathrm{~Pb} /{ }^{204} \mathrm{~Pb}$ in $\mathrm{Fig} .6 .3$. The major implication of the previous discussion is that apparent mixing curves exhibited by some islands on this diagram may contain temporal (albeit multi-stage) information. This hypothes is requires further testing, by paired analyses of $\mathrm{He}$ and $\mathrm{Pb}$ isotopes for intra-island suites. Trends for individual volcanic suites on the ${ }^{4} \mathrm{He} /{ }^{3} \mathrm{He}-{ }^{206} \mathrm{~Pb} /{ }^{204} \mathrm{~Pb}$ diagram will allow better assessment of both temporal factors and convective mixing of mantle components for $\mathrm{He}-\mathrm{Pb}$ isotope systematics.

Coherent behavior of $\mathrm{He}$ and $\mathrm{Pb}$ isotopes may also imply roughly similar residence times for $\mathrm{He}$ and $\mathrm{Pb}$ in the upper mantle. The He 
Figure $6.3{ }^{4} \mathrm{He} /{ }^{3} \mathrm{He}$ vs. ${ }^{206} \mathrm{~Pb} /{ }^{204} \mathrm{~Pb}$ for oceanic volcanic rocks. Paired analyses for Loihi from Kurz et al. (1983) and Staudigel et al. (1984); Reykjanes Ridge from Sun et al (1975) and Poreda et al. (1986); East African xenoliths from Cohen et al. (1984) and Porcelli et al. (1986). Ranges of values for other islands are from Kurz et al. (1982a; 1985; 1987), Staudacher et al. (1986), Sun and Jahn (1975), Tatsumoto (1978), Sun (1980) and Stille et al. (1987); Macdonald seamount and Guadalupe from Rison and Craig (1983) and Grall et al. (1985).

$\square$ EPR seamounts; $\star$ Shimada seamount; + Mathematicians seamounts; $\mathbf{V}$ Kick'em Jenny; $\Delta$ East African xenoliths. 


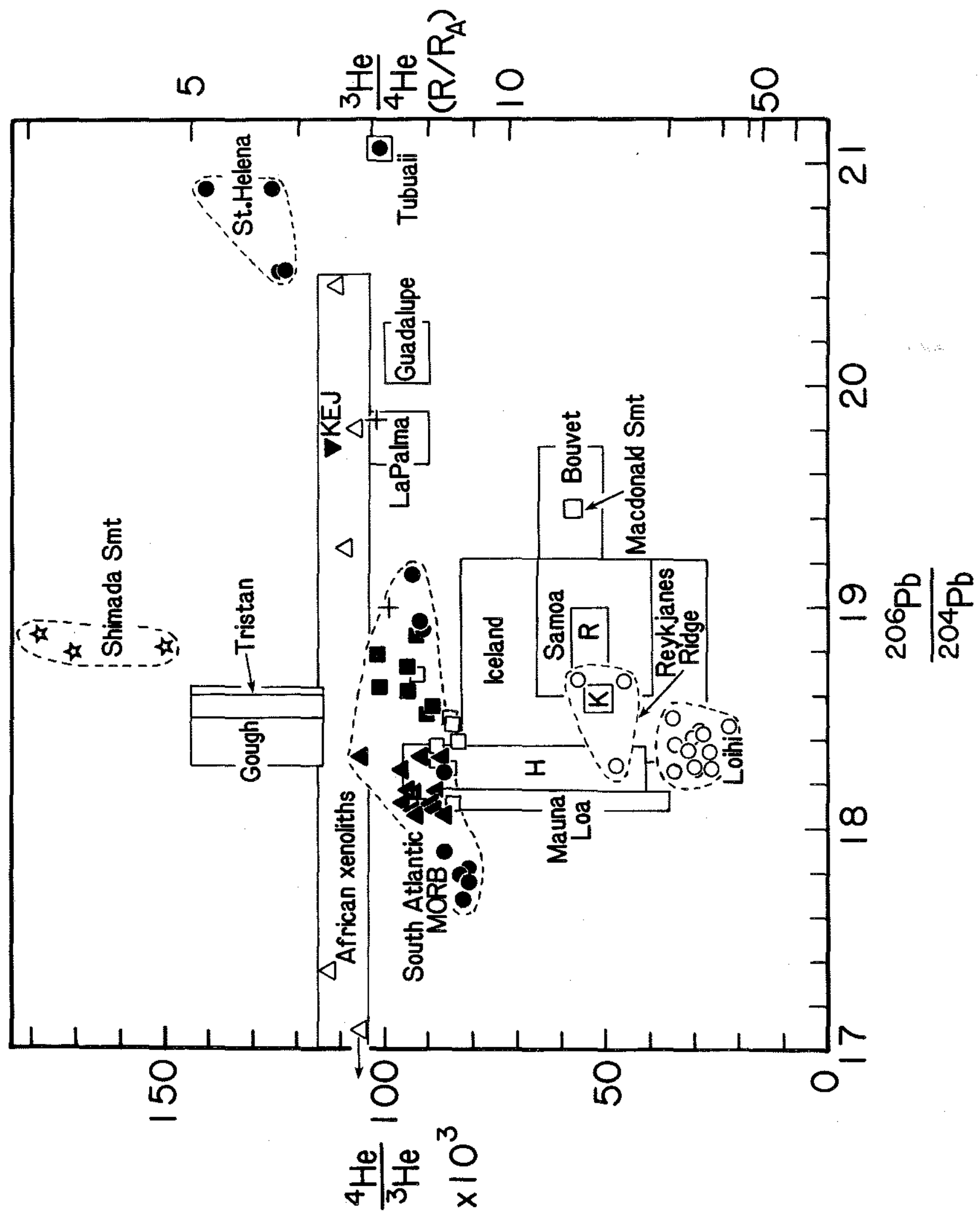


residence time can be approximated as $\tau_{u / H e}=[\mathrm{He}] /{ }^{4} \mathrm{He}$, where ${ }^{4} \mathrm{He}^{*}$ is the amount of radiogenic He produced during time $t$, calculated from eq. 1.2. Measured values for He and $U$ contents that may be relevant to estimating $\tau$ include 1) He and $U$ contents in MORB and 2) [He] in xenoliths and the estimated [U] in the upper mantle (Fig. 6.4). The first set of values can be used only if ratios of incompatible elements in MORB are not significantly fractionated during mantle melting and emplacement of seafloor lavas. This point, and the closed-system approximation for rare gas evolution in the upper mantle, has been a topic of conjecture (Hart et a1., 1985; Fisher, 1985; Galer and O'Nions, 1986; Allègre et 21., 1986b; Staudacher and Sarda, 1987). Using the highest [He] in MORB of $\sim 2.8 \times 10^{-5} \mathrm{CCSTP} / \mathrm{g}$ as measured by Fisher (1979) and Kurz (1982) (assuming all lower values represent variable degrees of He loss) and average [U] $=80 \mathrm{ppb}$ (Jochum et al., 1983), and assuming $211{ }^{3}$ He stems from contamination with primitive mantle material having ${ }^{3} \mathrm{He} /{ }^{4} \mathrm{He}$ equal to $32 \mathrm{R}_{\mathrm{A}}$, the highest value observed at Loihi (a simplification of the true case, which introduces a correction of $8.4 / 32$ or $\sim 25 \%$ to the estimated [He]), gives $\tau_{U / H}$ $\simeq 1.3 \mathrm{Ga}$ (for Th/U = 2.5; Fig. 6.4). As pointed out by Allègre et al. $(1986 b)$, the extent of degassing of MORB must be accounted for in such a calculation, and this represents a somewhat intractable problem at present. By using the highest [He] in MORB, the (unknown) extent of gas loss upon eruption serves to increase the estimate for $\tau_{u / \text { He. If }} \mathrm{He}$ is enriched over $U$ during basalt genesis at mid-ocean ridges, $\tau \simeq 1.3$ Ga is an overestmate. Secondly, the highest [He] in mantle xenoliths $\left(1.4 \times 10^{-6} \operatorname{ccSTP} / \mathrm{g}\right.$; Porcelli et $\left.a 1 ., 1986\right)$ and $[U]=5 \mathrm{ppb}$ in the 
Figure 6.4. Contours for upper mantle residence time for He (Ga) on [He] vs. [U] diagram for the upper mantle, with $T h / U=$ 2.5. The highest [He] in MORB is $\simeq 2.8 \times 10^{-5} \mathrm{ccSTP} / \mathrm{g}$ (Fisher, 1979; Kurz, 1982); average MORB [U] $=80 \mathrm{ppb}$ (Jochum et al., 1983). The highest [He] in mantle xenoliths $=1.4 \times 10^{-6}$ CCSTP $/ \mathrm{g}$ (Porcelli et at., 1986). Upper mantle [U] is estimated from the He/heat relationship (O'Nions and Oxburgh, 1983). 


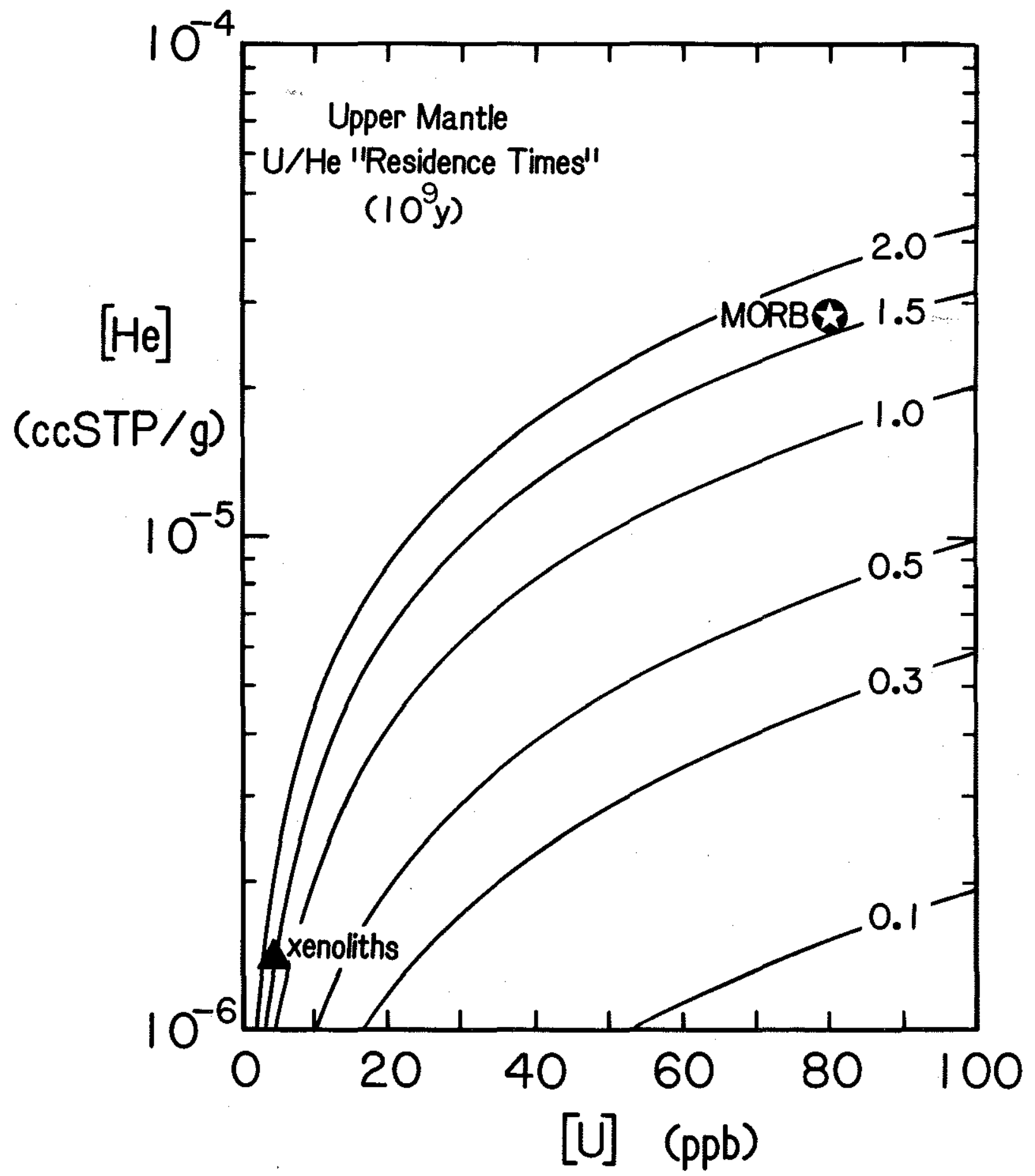


depleted mantle (based on the He/heat arguments of O'Nions and Oxburgh, 1983) also gives $\tau_{U / H e} \simeq 1.3 \mathrm{Ga}$. Both calculations of $\tau_{U / H}$ give ages that are longer than the estimated $\mathrm{Pb}$ residence time $(\sim 600$ m.y.; Galer and O'Nions, 1985; O'Nions, 1987). The $\mathrm{Pb}$ residence time, estimated from comparison of ${ }^{208} \mathrm{~Pb} /{ }^{204} \mathrm{~Pb}$ and ${ }^{230} \mathrm{Th}^{238} \mathrm{U}$ systematics, is a strong function of Th/U ( $x$ ) used for primitive mantle material. If $\kappa=4.2$ in the primitive Earth (as deduced from the temporal history of ${ }^{208} \mathrm{~Pb} /{ }^{204} \mathrm{~Pb}$ in komatiites by Allègre et al., 1986a) rather than 3.8 as used by Galer and O'Nions (1985), the $\mathrm{Pb}$ residence time in the upper mantle becomes longer $(\sim 1.5 \mathrm{Ga})$. The agreement of $\tau_{U / H e}$ based on concentrations in the material leaving the upper mantle (MORB) and in upper mantle material itself (xenoliths) suggests an approximate steady-state situation for He production and loss, in agreement with estimated fluxes of He from upper and lower mantle to the atmosphere and production within the upper mantle by $U$ and Th decay (Allègre et al.; 1986b) .

The previous discussion is predicated on the closed-system approximation for upper mantle evolution of ${ }^{4} \mathrm{He}$. Although this approximation cannot be strictly correct, it may allow a limit to be placed on $\tau_{U / H e}$. Even accounting for open-system behavior by entrainment of ${ }^{3} \mathrm{He}$ (and ${ }^{4} \mathrm{He}$ ) from primitive mantle material (assuming no isotopic fractionation during entrainment), the excess ${ }^{4} \mathrm{He}$ must be due to radiogenic production. Unless fractionation of $\mathrm{He}$ from $U_{+} T h$ during the melting process beneath ridges and islands is volumetrically important (as opposed to the possible "mining" of He from small scale "veins" of enriched material that ultimately give rise to alkalic-rich 
rocks at seamounts, such as discussed in chapter 4 ), the upper mantle residence times of $\mathrm{He}$ and $\mathrm{Pb}$ may not be drastically different. Similar He and $\mathrm{Pb}$ residence times suggest that their removal from the upper mantle is governed by a relatively non-fractionating movement of melt or fluids from the Earth's interior to its surface. Reconciling local enrichment effects beneath ridges during partial melting (such as varying source volumes for elements of different incompatibility; Galer and O'Nions, 1986) with mass balance requirements for a steady-state upper mantle remains an important unresolved problem in geochemistry.

\subsection{He-Pb-Sr-Nd Mantle Component Structures}

A summary of the isotope characteristics of distinct mantle components is presented in Table 6.2. The origin of these structures has been debated by numerous authors and is briefly reviewed here with respect to the relationships between He and the other isotopic systems.

Based on a consideration of all the isotopes, no single component appears to be a viable representative of primitive (undepleted) mantle (or "bulk earth"). This conclusion has been made previously (see Dupré and Allègre, 1983; Zindler and Hart, 1986a).

The origin of EM 1 has been suggested to reflect metasomatized mantle (Richardson et a1., 1982), or subducted crust or sediments (White, 1985). Some samples derived from EM 1 (as represented by Walvis Ridge) plot on or very close to the geochron in ${ }^{207} \mathrm{~Pb} /{ }^{204} \mathrm{~Pb}$ vs. ${ }^{206} \mathrm{~Pb} /{ }^{204} \mathrm{~Pb}$ and near "bulk earth" on the ${ }^{143} \mathrm{Nd} /{ }^{144} \mathrm{Nd}$ vs.

${ }^{87} \mathrm{Sr} /{ }^{86} \mathrm{Sr}$ array. ${ }^{3} \mathrm{He} /{ }^{4} \mathrm{He}$ in this component is not particularly wel1-characterized. If the ${ }^{3} \mathrm{He} /{ }^{4} \mathrm{He}$ at Tristan da Cunha and Gough 
Table 6.2

Isotope Characteristics

of Mantle Components

\begin{tabular}{|c|c|c|c|c|c|}
\hline Component & ${ }_{20}^{20} \frac{{ }^{4}}{\mathrm{~Pb}}$ & ${ }^{8}{ }^{7} \frac{\mathrm{Sr}}{\mathrm{Sr}}$ & $143 \frac{\mathrm{Nd}}{144}$ & ${ }^{3} \frac{\mathrm{He}}{\mathrm{He}}$ & Examples \\
\hline DM & low & $\begin{array}{l}\text { low } \\
<0.704\end{array}$ & $\begin{array}{l}\text { high } \\
>0.5128\end{array}$ & $8.4 \mathrm{R}_{\mathrm{A}}$ & $\begin{array}{l}\text { "normal" } \\
\text { MORB }\end{array}$ \\
\hline HI 3 & $\begin{array}{l}\text { low } \\
<18.7\end{array}$ & $\begin{array}{l}\text { low } \\
<0.704\end{array}$ & $\begin{array}{l}\text { inter- } \\
\text { high }\end{array}$ & $32 R_{A}$ & Loini \\
\hline EM 1 & $\begin{array}{l}\text { low } \\
<18.5 \text { and } \\
\text { relatively }\end{array}$ & $\begin{array}{l}\text { inter } \\
y \text { high }{ }^{2}\end{array}$ & $\begin{array}{l}\text { low } \\
\mathrm{b} / 204 \mathrm{~Pb}, 20\end{array}$ & $\begin{array}{c}5-6 \mathrm{R}_{\mathrm{A}} \\
{ }^{8} \mathrm{~Pb} / 20{ }^{4} \mathrm{~Pb}\end{array}$ & $\begin{array}{l}\text { Walvis } \\
\text { (Gough) }\end{array}$ \\
\hline EM 2 & $\begin{array}{l}\text { inter } \\
\sim 19.0 \text { and } \\
\text { relatively }\end{array}$ & $\begin{array}{l}\text { high } \\
y \text { high }\end{array}$ & $\begin{array}{l}\text { low-inter } \\
/^{204} \mathrm{~Pb},\end{array}$ & $\begin{array}{c}4-5 R_{A} \\
{ }^{8} \mathrm{~Pb} / 204 \mathrm{~Pb}\end{array}$ & Shimada \\
\hline HIMU & $\begin{array}{l}\text { high } \\
>19.5\end{array}$ & $\begin{array}{l}\text { low } \\
<0.7035\end{array}$ & $\begin{array}{l}\text { inter- } \\
\text { high }\end{array}$ & $6-7 R_{A}$ & $\begin{array}{l}\text { St. Helena } \\
\text { Tubuaif }\end{array}$ \\
\hline
\end{tabular}

$D M=$ depleted mantle; $E M=$ enriched mantle;

$\mathrm{HI} 3=\mathrm{high}{ }^{3} \mathrm{He} /{ }^{4} \mathrm{He} ; \mathrm{HIMU}=\mathrm{high}^{238} \mathrm{U} /{ }^{204} \mathrm{~Pb}$

The structures of these components follow many of the arguments presented by White (1985) and Zindler and Hart (1986a), and are based primarily on data from Richardson et al. (1982), Vidal et al. (1983), Staudigel et a 1. (1984), Palacz and Saunders (1986), Wright and White (1986), Kurz et al. (1982a, b; 1983; 1985) and this study.

Other islands which have partial signatures of these components (not comprehensive) include

HI 3-Hawai ian Islands, Iceland, Bouvet, Reunion, Macdonald seamount

EM 1-Kerguelen, Tristan da Cunha, Koolau (Oahu)

HIMU-Australs, Cooks, Comores, Guadalupe

EM 2-Tristan da Cunha, Gough, Societies, Marquesas, Cooks, Australs, Macdonald Seamount, Bouvet, Sao Miguel (Azores), Reunion, Rodrigues, St. Paul, Crozet 
(apparently derived by mixture of EM 1 and EM 2) are indicative of an EM 1 signature, and if this component represents some degree of primitive mantle, the He-Sr (Kurz et al., 1982a) and He-Pb systematics (Fig. 6.3) require that recent generation of high $\left(U_{+} T h\right) / H e$ has modified "bulk earth" He isotope signatures in all cases where this component has been sampled. Although this cannot be excluded as a possibility, it is ad hoc.

The origin of HI 3 material, if it reflects a discrete component, remains enigmatic. $\mathrm{Pb}$ isotope compositions at Loini plot close, but to the right of the geochron, requiring an evolution with some enrichment of $\mathrm{U} / \mathrm{Pb}$. Nd-Sr isotope compositions clearly indicate that the source has been depleted in $\mathrm{Rb} / \mathrm{Sr}$ and $\mathrm{Nd} / \mathrm{Sm}$. The major fractionation event producing depleted $\mathrm{Rb} / \mathrm{Sr}$ and $\mathrm{Nd} / \mathrm{Sm}$ in the mantle was the extraction of the continental crust (Allègre, 1982), and the mean age of this event was $\sim 2$ Ga. Thus, HI 3 likely experienced some degree of ancient magma extraction during this process. Subsequently, fluids enriched in ${ }^{3} \mathrm{He} /(U+T h)$ (possibly stemming from the lower mantle) may have enriched the source region. For example, the HI 3 source region may represent the old residue of a "frozen" kimberlitic-type magma. Such a source region could evolve with high ${ }^{3} \mathrm{He} /\left(U_{+} \mathrm{Th}\right), \mathrm{Rb} / \mathrm{Sr}$ and $\mathrm{Nd} / \mathrm{Sm}$, and with $\mathrm{U} / \mathrm{Pb}$ slightly higher than bulk earth. By this mechanism, the high ${ }^{3} \mathrm{He} /{ }^{4} \mathrm{He}$ in itself does not necessarily imply the presence of the most primitive mantle material (in contrast to primitive He) in this component.

Several origins for EM 2 have been suggested, including subducted oceanic crust (Hofmann and White, 1982), subducted continental crust (White and Hofmann, 1982; Shirey et a1., 1987), subducted sediments (Chase, 1981; Cohen and $0^{\prime}$ Nions, 1982b), delaminated sub-continental 
lithosphere (McKenzie and $0^{\prime}$ Nions, 1982), and mantle metasomatism (Menzies and Murthy, 1980; Allègre and Turcotte, 1985). The ${ }^{3} \mathrm{He} /{ }^{4} \mathrm{He}$ at Shimada (where $\mathrm{Pb}, \mathrm{Sr}$ and $\mathrm{Nd}$ isotopes indicate the presence of an $\mathrm{EM} 2$ component) is $\sim 4-5 R_{A}$, similar to ${ }^{3} \mathrm{He} /{ }^{4} \mathrm{He}$ in $E M 1$ type material $\left(\sim 5-6 R_{A}\right) .{ }^{3} \mathrm{He} /{ }^{4} \mathrm{He}$ does not appear to distinguish between recycled materials or metasomatism as the origin for these components. If the origin of EM 1 and EM 2 lies in different recycled materials, and these have similar residence times within the upper mantle, then these materials do not appear to have very different $(U+T h) /{ }^{3} \mathrm{He}$. Continental materials appear to be viable sources for EM 1 and EM 2 based on $\mathrm{Pb}-\mathrm{Sr}-\mathrm{Nd}$ isotope systematics (Hart et al., 1986). ${ }^{3} \mathrm{He} /{ }^{4} \mathrm{He}$ in mantle xenoliths from continental regions ( $6 \mathrm{R}_{\mathrm{A}}$; Porcelli et al., 1986; Polvé and Kurz, 1987) is similar to ${ }^{3} \mathrm{He} /{ }^{4} \mathrm{He}$ in oceanic rocks that have $\mathrm{Pb}, \mathrm{Sr}$ and $\mathrm{Nd}$ isotope signatures derived from EM 1 and EM 2 sources.

Several origins for HIMU (St. Helena-type) have also been forwarded, including subducted old oceanic crust (Zindler et al., 1982), subducted continental crust (Allègre et al., 1980), metasomatized old mantle (Vidal and Dosso, 1978; Allègre and-Turcotte, 1985) and lower mantle which suffered $\mathrm{Pb}$ extraction to the core (Vollmer, 1977). The abundances of siderophile (Mo and $W$ ) and chalcophile (Mo and $\mathrm{Pb}$ ) elements in oceanic basalts has provided important constraints for distinguishing between some of these hypotheses (Newsom et al., 1986). No systematic variations in Mo, $\mathrm{Pr}$ or $\mathrm{W}$ were found for the range of $\mathrm{Pb}$ isotope variations in oceanic volcanic rocks (e.g., Mo/Pr is relatively constant, and Mo is both highly siderophile and chalcophile, with liquid $D^{\text {Fe/si }}=2500$ and 
liquid $\left.D^{\text {sulfide/si }}=1250\right)$. Therefore, $\mathrm{Pb}$ extraction $\left(D^{\text {sulfide/si }}=\right.$ 7) by core formation does not appear to explain the highly radiogenic $\mathrm{Pb}$ in some OIB. Also, the $\mathrm{Pb} / \mathrm{Ce}$ ratio of both MORB and OIB is essentially constant, suggesting very little fractionation of this elemental ratio during magmagenesis (Newsom et a1., 1986; Hofmann et a1., 1986). The $\mathrm{Pb} / \mathrm{Ce}$ ratio for the mantle $(\sim 0.036)$ is significantly lower than values for the primitive mantle (chondritic $\mathrm{Pb} / \mathrm{Ce} \sim 0.1$ ) and much less than for the continental crust $(\sim 0.25)$. This suggests that a non-magmatic process, as well as a magmatic one, was involved in early $\mathrm{Pb}$ transport to the continental crust. Newsom et al. (1986) propose that this occurred via a net flux of $\mathrm{Pb}$ to the crust through hydrothermal activity. If the oceanic crust is altered by addition of seawater $U$ before its subduction, a further increase occurs in mantle $\mu$ values. The relative constancy of $\mathrm{Pb} / \mathrm{Ce}$ in ocean basalts is also consistent with the notion that primitive mantle material does not appear to represent the primary component of any ocean island basalt source.

Subducted old oceanic crust (only moderately altered by $U$ addition) is favored here as the source for HIMU, in light of the low ${ }^{87} \mathrm{Sr} /{ }^{86} \mathrm{Sr}$, radiogenic ${ }^{206} \mathrm{~Pb} /{ }^{204} \mathrm{~Pb}$ and ${ }^{207} \mathrm{~Pb} /{ }^{204} \mathrm{~Pb}$ and moderately low ${ }^{3} \mathrm{He} /{ }^{4} \mathrm{He}$ in this component. The relatively low ${ }^{208} \mathrm{~Pb} /{ }^{204} \mathrm{~Pb}$ compared to the horthern hemisphere reference line (Fig. 4.3) suggests long term evolution with relatively low $k(<3)$. The HIMU component does not seem to have drastically dissimilar $(U+T h) /{ }^{3} \mathrm{He}$ from EM 1 or EM 2. This similarity could arise in at least two different ways. In one case, these components may represent discrete packages of material which were separated from the mantle at some time in the past 
and which resided in reservoirs (e.g., the sub-continental lithosphere for EM 1) with $(U+T h) /{ }^{3} \mathrm{He}$ only slightly above that for depleted mantle. In this regard it must be borne in mind that depleted MORB mantle may itself be contaminated with ${ }^{3} \mathrm{He}$ by injection of primitive material from below, if the mantle is layered with respect to rare gases (Allègre et al., 1983). Alternatively, the EM and HIMU components have time-integrated histories with different, elevated $(U+T h) /{ }^{3} \mathrm{He}$. Prior to (or during) their recycling, these materials may have lost much of the ir complement of helium (low ${ }^{3} \mathrm{He} /{ }^{4} \mathrm{He}$ component). Subsequent mixing with very small proportions of other components containing higher He concentrations (e.g., with depleted mantle) would produce a mixture with only slightly lower ${ }^{3} \mathrm{He} /{ }^{4} \mathrm{He}$ than depleted mantle. 


\section{REFERENCES}

Abdel-Monem, A. and P. W. Gast (1967) Age of volcanism on St. Helena. Earth Planet. Sci. Lett. 2: 415-418.

Allan, J. and R. Batiza (1987) Petrology of lavas from seamounts flanking the East Pacific Rise, $21^{\circ} \mathrm{N}$ : Implications concerning the mantle source composition for both seamount and adjacent EPR lavas. J. Geophys. Res.: in press.

Allègre, C. J. (1982) Chemical geodynamics. Tectonophys. 81: 109-132.

Allègre, $C$. J. and $M$. Condomines (1982) Basalt genesis and mantle structure studied through Th-isotopic geochemistry. Nature 299: 21-24.

Allègre, C. J. and D. L. Turcotte (1985) Geodynamic mixing in the mesosphere boundary layer and the origin of oceanic islands. Geophys. Res. Lett. 12: 207-210.

Allègre, C. J. and D. L. Turcotte (1986) Implications of a two component marble-cake mantle. Nature 323: 123-127.

Allègre, C. J., D. B. Othman, M. Polvé and P. Richard (1979) The Nd-Sr isotopic correlation in mantle materials and geodynamic consequences. Phys. Earth Planet. Inter. 19: 293-306.

Allègre, C. J., O. Brevart, B. Dupré and J. F. Minster (1980) Isotopic and chemical effects produced in a continuously differentiating convecting Earth mantle. Phil. Trans. R. Soc. Lond. A 297: 447-477.

Allègre, C. J., T. Staudacher, P. Sarda and M. D. Kurz (1983) Constraints on evolution of Earth's mantle from rare gas systematics. Nature 303: 762-766.

Allègre, C. J., B. Hamel in and B. Dupré (1984) Statistical analys is of isotopic ratios in MORB: the mantle blob cluster model and the convective regime of the mantle. Earth Planet. Sci. Lett. 71: 71-84.

Allègre, C. J., B. Dupré and E. Lewin (1986a) Thorium/uranium rătio of the Earth. Chem. Geol. 56: 219-227.

Allegre, C. J., T. Staudacher and P. Sarda (1986b) Rare gas systematics: formation of the atmosphere, evolution and structure of the Earth's mantle. Earth Planet. Sci. Lett. 81: 127-150.

Allègre, C. J., B. Hamel in, A. Provost and B. Dupré (1987) Topology in isotopic multispace and origin of mantle chemical heterogeneities. Earth Planet. Sci. Lett. 81: 319-337.

Anderson, D. L. (1985) Hotspot magmas can form by fractionation and contamination of mid-ocean ridge basalts. Nature 318: 145-149.

Andrews, J. N. (1985) The isotopic composition of radiogenic helium and its use to study groundwater movement in confined aquifers. Chem. Geo1. 49: 339-351.

Baker, I. (1969) Petrology of the volcanic rocks of Saint Helena island, South Atlantic. Geol. Soc. Amer. Bull. 80: 1283-1310.

Baker, I., N. H. Gale and J. Simons (1967) Geochronology of the Saint Helena volcanoes. Nature 215: 1451-1456.

Batiza, R. (1977) Age, volume, compositional and spatial relations of small isolated oceanic central volcanoes. Mar. Geol. 24: 169-183.

Batiza, R. (1980) Origin and petrology of young oceanic central volcanoes: are most tholeiitic rather than alkalic?. Geol. 8: $477-482$. 
Batiza, R. (1982) Abundances, distribution and sizes of volcanoes in the Pacific Ocean and implications for the origin of non-hotspot volcanoes. Earth Planet. Sci. Lett. 60: 195-206.

Batiza, R. and D. Vanko (1983) Volcanic development of small oceanic central volcanoes on the flanks of the East Pacific Rise inferred from narrow-beam echo-sounder surveys. Mar. Geol. 54: 53-90.

Batiza, R. and D. Vanko (1984) Petrology of young Pacific seamounts. J. Geophys. Res. 89: 11235-11260.

Batiza, R. and D. Vanko (1985) Petrologic evolution of large failed rifts in the eastern Pacific: petrology of volcanic and plutonic rocks from the Mathematicians Ridge area and the Guadalupe trough. J. Petrol. 26: 564-602.

Batiza, R., D. J. Fornari, D. A. Vanko and P. Lonsdale (1984) Craters, calderas and hyaloclastites on young Pacific seamounts. J. Geophys. Res. 89: 8371-8390.

Bender, M.L. (1970) Helium-uranium dating of corals. Phd. thesis, Columbia Univ. (1970).

Benjamin, T., W. R. Heuser, D. S. Burnett and M. G. Seitz (1980) Actinide crystal-liquid partitioning for clinopyroxene and $\mathrm{Ca}_{3}\left(\mathrm{PO}_{4}\right)_{2}$. Geochim. Cosmochim. Acta 44: 1251-1264.

Bickle, M. J. and D. McKenzie (1987) The transport of heat and matter by fluids during metamorphism. Contrib. Mineral. Petrol. 95: 384-392.

Black, D. C. (1972) On the origin of trapped helium, neon and argon isotopic variations in meteorites, II. Carbonaceous meteorites. Geochim. Cosmochim. Acta 36: 377-394.

Carlson, R. W., J. D. Macdougall and G. W. Lugmair (1978) Differential $\mathrm{Sm} / \mathrm{Nd}$ evolution in oceanic basalts. Geophys. Res. Lett. 5: 229 232.

Catanzaro, E. J., T. J. Murphy, W. R. Shields and E. L. Garner (1968) Absolute isotopic abundance ratios of common, equal-atom, and radiogenic lead isotopic standards. J. Res. Natl. Bur. Stand. $72 A$.

Chase, C.G. (1981) Oceanic island Pb: two-stage histories and mantle evolution. Earth Planet. Sci. Lett. 52: 277-284.

Church, S. E. and M. Tatsumoto (1975) Lead isotope relations in oceanic ridge basalts from the Juan de Fuca-Gorda Ridge area, N. E. Pacific Ocean. Contr. Mineral. Petrol. 53: 253-279.

Clarke, W. B., W. J. Jenkins and Z. Top (1976) Determination of tritium by mass spectrometric measurement of ${ }^{3} \mathrm{He}$. Inter. J. Appl. Rad. and Isotopes 27: 515-522.

Cohen, R. S. and R. K. O'Nions (1982a) The lead, neodymium and strontium isotopic structure of ocean ridge basalts. J. Petrol. 23: 299-324.

Cohen, R. S. and R. K. O Nions (1982b) Identification of recycled continental material in the mantle from $\mathrm{Sr}, \mathrm{Nd}$ and $\mathrm{Pb}$ isotope investigations, Earth Planet. Sci. Lett. 61: 73-84.

Cohen, R. S., N. M. Evensen, P. J. Hamilton and R. K. O'Nions (1980) $\mathrm{U}-\mathrm{Pb}, \mathrm{Sm}-\mathrm{Nd}$, and $\mathrm{Rb}-\mathrm{Sr}$ systematics of mid-ocean ridge basalt glasses. Nature, 283: 149-153.

Cohen, R. S., R. K. O'Nions and J. B. Dawson (1984) Isotope geochemistry of xenoliths from East Africa: implications for development of mantle reservoirs and their interaction. Earth Planet. Sci. Lett. 68: 209-220. 
Cole, M. W., B. B. Hanan, R. Kingsley and J.-G. Schilling (1985) Isotopic variations in South Atlantic MAR basalts: implications on mantle plume-migrating ridge dynamics. EOS 66: 408 .

Condomines, M., K. Gronvold, P. J. Hooker, K. Muehlenbachs, R. K. O'Nions, N. Oskarsson and E. R. Oxburgh (1983) Helium, oxygen, strontium and neodymium isotopic relationships in Icelandic volcanics. Earth Planet. Sci. Lett. 66: 125-136.

Craig, H. and J. E. Lupton (1976) Primordial neon, helium and hydrogen in oceanic basalts. Earth Planet. Sci. Lett. 31: 369-385.

Craig, H., W. B. Clarke and M. A. Beg (1975) Excess ${ }^{3}$ He in deep water on the East Pacific Rise. Earth Planet. Sci. Lett. 26: 125-132.

Craig, H., J. E. Lupton and Y. Horibe (1978) A mantle He component in circum-Pacific volcanic gases: Hakone, the Marianas and Mt. Lassen. In: Terrestrial Rare Gases, E. C. Alexander, Jr. and M. Ozima, eds ..

Damon, P. E. and J. L. Kulp (1958) Excess helium and argon in beryl and other minerals. Amer. Mineral. 43: 433-459.

Duncan, R. (1981) Hotspots in the Sothern Oceans-an absolute frame of reference for the motion of Gondwana continents. Tectonophys. 74: 29-42.

Duncan, R. A., M. T. McCulloch, H. G. Barsczus and D. R. Nelson (1986) Plume versus 1 ithospheric sources for melts at Ua Pou, Marquesas Islands. Nature 322: 534-538.

Dupré, B. (1983) Structure et evolution du manteau terrestre etudiees a l'aide des traceurs isotopiques couples $\mathrm{Sr}-\mathrm{Pb}$. Thesis, University of Paris VII.

Dupré, B. and C. J. Allègre (1983) $\mathrm{Pb}-\mathrm{Sr}$ isotope variation in Indian Ocean basalts and mixing phenomena, Nature 303: 142-146.

Dupré, B. and L. M. Echeverria (1984) Pb isotopes of Gorgona Is land (Colombia): isotopic variations correlated with magma type. Earth Planet. Sci. Lett. 67: 186-190.

Fanale, F. P. and J. L. Kulp (1962) The helium method and the age of the Cornwall Pennsylvania magnetite ore. Econ. Geol. 57: 735-746.

Faure, G. (1977) Principles of Isotope Geology. John Wiley and Sons, N. Y.

Fisher, D. E. (1979) He and $\overline{X e}$ in deep-sea basalts as a measure of magmatic differentiation. Nature 282: 825-827.

Fisher, D. E. (1985) Radiogenic rare gases and the evolutionary history of the depleted mantle. J. Geophys. Res. 90: 1801-1807.

Flemings, M. C. (1974) Solidification Processing. McGraw-Hill, N.Y..

Frey, F. A. and D. A. CTague (1983) Geochemistry of diverse basalt types from Loihi Seamount, Hawaii: petrogenetic implications. Earth Planet. Sci. Lett. 66, 337-355.

Friedlander, G., J. W. Kennedy and J. M. Miller (1964) Nuclear and Radiochemistry, second edition. John Wiley and sons, N. Y..

Gale, N. H. and A. E. Mussett (1973) Episodic uranium-lead models and the interpretation of variations in the isotopic composition of lead in rocks. Rev. Geophys. Space Phys. 11: 37-86.

Galer, S. J. G. and R. K. O'Nions (19 $\overline{85}$ ) Residence time of uranium, thorium and lead in the mantle with implications for mantle convection. Nature 316: 778-782.

Galer, S. J. G. and R. K. O'Nions (1986) Magmagenesis and the mapping of chemical and isotopic variations in the mantle. Chem. Geol. 56: 45-61. 
Gardner, J. V., W. E. Dean and R. J. Blakely (1984) Shimada Seamount: an example of recent mid-plate volcanism. Geol. Soc. Amer. Bull. 95: $855-862$.

Gast, P. W. (1969) The isotopic composition of lead from St. Helena and Ascension islands. Earth Planet. Sci. Lett. 5: 353-359.

Gope 1, C., G. Manhes and C. J. Allègre (1985) U-P b systematics in iron meteorites: uniformity of primordial lead. Geochim. Cosmochim. Acta 49: 1681-1695.

Graham, D. W., A. Zindler, L. Reisberg, M. D. Kurz, W. J. Jenkins and R. Batiza (1984) He, $\mathrm{Sr}$ and $\mathrm{Nd}$ isotopes in basaltic glasses from young Pacific seamounts. EOS 65: 1079.

Graham, D. W., W. J. Jenkins, M. D. Kurz and R. Batiza (1987) Helium isotope disequilibrium and geochronology of glassy submarine basalts. Nature 326: 384-386.

Grall, H. M., B. B. Hanan, E. A. Okal and J.-G. Schilling (1985) The Macdonald hotspot: $\mathrm{Pb}$ isotopes. EOS 66: 409 .

Green, D. H. (1973) Experimental melting studies on a model upper mantle composition at high-pressure under water-saturated and water-undersaturated conditions. Earth. Planet. Sci. Lett. 19: 37-53.

Green, D. H. and A. E. Ringwood (1967) The genesis of basaltic magma. Contrib. Mineral. Petrol. 15: 103-190.

Grove, T. L. and W. B. Bryan (1983) Fractionation of pyroxene-phyric MORB at low pressure: an experimental study. Contrib. Mineral. Petrol. 84: 293-309.

Gurnis, M. (1986) Stirring and mixing by plate-scale flow: large persistent blobs and long tendrils coexist. Geophys. Res. Lett. 13: 1474- 1477.

Hamelin, B. and C. J. Allègre (1985) Large-scale regional units in the depleted upper mantle revealed by an isotope study of the South-West Indian Ridge. Nature 315: 196-199.

Hamel in, B., B. Dupré and C. J. Allègre (1984) Lead-strontium isotopic variations along the East Pacific Rise and Mid-Atlantic Ridge: a comparative study. Earth Planet. Sci. Lett. 67: 340-350.

Hamelin, B., B. Dupré and C. J. Allègre (1985a) $\overline{\mathrm{Pb}}-\mathrm{Sr}-\mathrm{Nd}$ i sotopic data of Indian Ocean ridges: new evidence of large-scale mapping of mantle heterogeneities, Earth Planet. Sci. Lett. 76: 288-298.

Hamelin, B., G. Manhès, F. Albarède and C. J. ATlègre (1985b) Precise lead isotope measurements by the double spike technique: a reconsideration. Geochim. Cosmochim. Acta 49: 173-182.

Hanan, B., R. H. Kingsley and J.-G. Schilling (1986) Pb isotope evidence in the South Atlantic for migrating ridge-hotspot interactions. Nature 322: 137-144.

Hart, R., L. Hogan and J. Dymond (1985) The closed-system approximation for evolution of argon and helium in the mantle, crust and atmosphere, Chem. Geol. (Isotope Geosci.) 52: 45-73.

Hart, S. R. (1984) A large-scale isotope anomaly in the southern hemisphere mantle. Nature 309: 753-757.

Hart, S. R. and A. Zindler (19 $\overline{877}$ Constraints on the nature and development of chemical heterogeneities in the mantle. In Mantle Convection, R. Peltier, ed., in press 
Hart, S. R., D. C. Gerlach and W. M. White (1986) A possible new Sr-Nd-Pb mantle array and consequences for mantle mixing. Geochim. Cosmochim. Acta 50: $1551-1557$.

Hofmann, A. W. and S. R. Hart (1978) An assessment of local and regional isotopic equilibrium in the mantle. Earth Planet. Sci. Lett. 38: 44-62.

Hofmann, A. W. and W. M. White (1982) Mantle plumes from ancient oceanic crust. Earth Planet. Sci. Lett. 57: 421-436.

Hofmann, A. W., K. P. Jochum, M. Seufert and W. M. White (1986) Nb and Pb in oceanic basalts: new constraints on mantle evolution. Earth Planet. Sci. Lett. 79: 33-45.

Honda, M., T. Bernatowi $\overline{C Z}$, F. A. Podosek, R. Batiza and P. T. Taylor (1987) Age determinations of Eastern Pacific seamounts (Henderson, 6 and 7)-implications for near-ridge and intraplate volcanism. Mar. Geo1. 74: 79-84.

Humphris, S. E., G. Thompson, J.-G. Schilling and R. H. Kingsley (1985) Petrological and geochemical variations along the Mid-Atiantic Ridge between $46^{\circ} \mathrm{S}$ and $32^{\circ} \mathrm{S}$ : influence of the Tristan da Cunha mantle plume. Geochim. Cosmochim. Acta 49: 1445-1464.

Hurley, P. M. (1950) Determination of radioactivity in granites and possible relation to helium age measurement. Geol. Soc. Amer. Bull. 61: $1-8$.

Jacques, A. L. and Green, D. H. (1980) Anhydrous melting of peridotite at $0-15$ kbar pressure and the genesis of tholeitic basalts. Contrib. Mineral. Petrol. 73: 287-310.

Jaeger, J. C. (1957) The temperature in the neighborhood of a cooling intrusive sheet. Amer. J. Sci. 255: 306-318.

Jambon, A., H. W. Weber and F. Begemann (1985) Helium and argon from an Atlantic MORB glass: concentration, distribution and isotopic composition. Earth Planet. Sci. Lett. 73: 255-267.

Jenkins, W. J. (1974) Helium isotope and rare gas oceanology. Pho. Diss., McMaster Univ.

Jenkins, W. J., J. M. Edmond and J. B. Corliss (1978) Excess ${ }^{3} \mathrm{He}$ and ${ }^{4} \mathrm{He}$ in Galapagos submarine hydrothermal waters. Nature 272: 156-158.

Jochum, K. P., A. W. Hofmann, E. I to, H. M. Seufert and W. M. White (1983) $K, U$ and Th in mid-ocean ridge basalt glasses and heat production, $K / U$ and $K / R b$ in the mantle. Nature 306: 431-436.

Jost, W., (1952) Diffusion in Solids, Liquids and Gases. Academic Press, New York, N. Y. $558 \mathrm{pp}$.

Kay, R. W., S.-S. Sun and C. N. Lee-Hu (1978) Pb and $\mathrm{Sr}$ isotopes in volcanic rocks from the Aleutian Islands and Pribilof Islands, Alaska. Geochim. Cosmochim. Acta 42: 263-273.

Keevil, N. B. (1943) Helium indexes for several minerals and rocks. Amer. J. Sci. 241: 680-693.

Kurz, M.D. (1982) Helium isotope geochemistry of oceanic volcanic rocks: implications for mantle heterogeneity and degassing. Pho. Diss., MIT/WHOI.

Kurz, M. D. (1986) Cosmogenic helium in a terrestrial igneous rock. Nature 320: 435-439.

Kurz, M. D. and W. J. Jenkins (1981) The distribution of helium in oceanic basalt glasses. Earth Planet. Sci. Lett. 53: 41-54. 
Kurz, M. D., W. J. Jenkins and S. R. Hart (1982a) Helium-isotopic systematics of oceanic islands and mantle heterogeneity. Nature 297: 43-46.

Kurz, M. D., W. J. Jenkins, J.-G. Schilling and S. R. Hart (1982b) Helium isotopic variations in the mantle beneath the central North Atlantic Ocean. Earth Planet. Sci. Lett. 58: 1-14.

Kurz, M. D., W. J. Jenkins, S. R. Hart and D. Clague (1983) Helium isotopic variations in volcanic rocks from Loihi Seamount and the island of Hawaij. Earth Planet. Sci. Lett. 66: 388-406.

Kurz, M. D., P. S. Meyer and H. Sigurdsson (1985) Helium isotopic systematics within the neovolcanic zones of Icelend. Earth Planet. Sci. Lett. 74: 291-305, 1985.

Kurz, M. D., J.J. J. Gurney and W. J. Jenkins (1987a) Helium isotopic variability within single diamonds from the Orapa kimberlite pipe. Earth Planet. Sci. Lett.: in press.

Kurz, M. D., F. A. Frey, M. O. Garcia and P. A. O'Brien (1987b) Temporal helium isotopic variations within Hawailan volcanoes: basalts from Mauna Loa and Haleakala. Geochim. Cosmochim. Acta: in press.

Kushiro, I. (1973) Origin of some magmas in oceanic and circum-oceanic regions. Tectonophys. 17: 211-222.

Langmuir, C. H. and J. F. Bender (1984) The geochemistry of oceanic basalts in the vicinity of transform faults: observations and implications. Earth Planet. Sci. Lett. 69: 107-127.

Langmuir, C. H., J. F. Bender and R. Batiza (1986) Petrological and tectonic segmentation of the East Pacific Rise, $5^{\circ} 30^{\prime} \mathrm{N}-14^{\circ} 30^{\prime} \mathrm{N}$. Nature 322: 422-429.

Langmuir, C. H., R. D. Vocke Jr., G. N. Hanson and S. R. Hart (1978) A general mixing equation with applications to Icelandic basalts. Earth Planet. Sci. Lett. 37: 380-392.

LeBas, M. J., R. W. LeMaitre, A Streckeisen and B. Zanettin (1986) A chemical classification of volcanic rocks based on the total alkali-silica diagram. J. Petrol. 27: 745-750.

Lott, D. E. and W. J. Jenkins (1984) An automated cryogenic charcoal trap system for helium isotope mass spectrometry. Rev. Sci. Instrum. 55: 1982-1988.

Lupton, J. E. (1983) Terrestrial inert gases: isotope tracer studies and clues to primordial components in the mantle. Ann. Rev. Earth Planet. Sci. 11: 371-414.

Lux, G. (1987) The behavior of noble gases in silicate liquids: solution, diffusion, bubbles and surface effects, with applications to natural samples. Geochim. Cosmochim. Acta. 51, 1549-1560.

Macdonald, G. A. and T. Katsura (1964) Chemical composition of Hawailan lavas. J. Petrol. 5: 82-133.

Macdougal1, J. D. and $\bar{G}$. W. Lugmair (1986) $\mathrm{Sr}$ and $\mathrm{Nd}$ isotpes in basalts from the East Pacific Rise: significance for mantle heterogeneity.

Earth Planet. Sci. Lett. 77: 273-284.

MacDouga 11, J. D., R. C. Finkel, J. Carlson and S. Krishnaswami (1979) Isotopic evidence for uranium exchange during low-temperature alteration of oceanic basalt. Earth Planet. Sci. Lett. 42: 27-34. Mamyrin, B. A. and L. N. Tolstikhin (1985) Helium Isotopes in Nature, Elsevier. 
Marty, B. and M. Ozima (1986) Noble gas distribution in oceanic basalt glass. Geochim. Cosmochim. Acta 50: 1093-1097.

Mckenzie, D. (1985a) ${ }^{230} \mathrm{Th}^{238} \mathrm{U}$ disequilibrium and the melting processes beneath ridge axes. Earth Planet. Scj. Lett. 72: 149-157.

McKenzie, D. (1985b) The extraction of magma from the crust and mantle. Earth Planet. Sci. Lett. 74: 81-91.

McKenzie, D. and R. K. O'Nions (1984) Mantle reservoirs and ocean island basalts. Nature 301: 229-231.

McNutt, M. J. (1986) Nonuniform magnetization of seamounts: a least squares approach. J. Geophys. Res. 91: 3686-3700.

McNutt, M. and R. Batiza (1981) Paleomagnetism of northern Cocos seamounts: constraints on absolute plate motion. Geol. 9: 148-154.

Menard, H.W. (1969) Growth of drifting volcanoes. J. Geophys. Res. 74: 4827-4837.

Menzies, M. and V. R. Murthy (1980) Nd and $\mathrm{Sr}$ isotope geochemistry of hydrous mantle nodules and their host alkali basalts: implications for local heterogeneities in metasomatically veined mantle. Earth Planet. Sci. Lett. 46: 323-334.

Merlivat, L., F. Pineau and M. Javoy (1987) Hydrothermal vent waters at $13^{\circ} \mathrm{N}$ on the East Pacific Rise: isotopic composition and noble gas concentration. Earth Planet. Sci. Lett. 84: 100-108.

Morrison, P. and J. Pine (1955) Radiogenic origin of the helium isotopes in rock. Annals N. Y. Acad. Sci. 62: 69-92.

Natland, J. H. and W. G. Melson (1980) Compositions of basaltic glasses from the East Pacific Rise and Siqueiros Fracture Zone, near $9^{\circ} \mathrm{N}$. In Init. Rep. DSDP 54, 705-723, B. R. Rosendah1, R. Hekinian et a 1., eds.

Natland, J. H. and J. D. Macdougall (1986) Parental abyssal tholeittes and alkali basalts at the East Pacific Rise near $9^{\circ} \mathrm{N}$ and the Siqueiros Fracture Zone. EOS 67: 410-411.

Newman, S., R. C. Finkel and J. D. Macdougall (1983) ${ }^{230} \mathrm{Th}^{238} \mathrm{U}$ disequilibrium systematics in oceanic tholeiites from $21^{\circ} \mathrm{N}$ on the East Pacific Rise. Earth Planet. Sci. Lett. 65: 17-33.

Newman, S., R. C. Finkel and J. D. Macdougall (1984) Comparison of ${ }^{230} \mathrm{Th}-{ }^{238} \mathrm{U}$ disequilibrium systematics in lavas from three hot spot regions: Hawai i, Prince Edward and Samoa. Geochim. Cosmochim. Acta 48: 315-324.

Newsom, H. E., W. M. White, K. P. Jochum and A. W. Hofmann (1986) Siderophile and chalcophile element abundances in oceanic basalts, $\mathrm{Pb}$ isotope evolution and growth of the Earth's core. Earth Planet. Sci. Lett. 80: 299-313.

Nier, A. 0. (1940) A mass spectrometer for routine isotope abundance measurements. 11: 212-216.

Noble, C. S. and J.J. Naughton (1968) Deep ocean basalts: inert gas content and uncertainties in age dating. Science 162: 265-267.

O'Hara, M. J. (1985) Importance of the "shape" of the melting regime during partial melting of the mantle. Nature 314: 58-62.

O'Nions, R. K. (1987) Relationships between chemical and convective layering in the Earth. J. Geol. Soc. Lond. 144: 259-274.

O'Nions, R. K. and E. R. Oxburgh (1983) Heat and helium in the Earth, Nature 306: 429-431, 1983. 
O'Nions, R. K., N. M. Evensen and P. J. Hamilton (1979) Geochemical modelling of mantle differentiation and crustal growth. J. Geophys. Res. 84: 6091-6101.

Oversby, V. M. and P. W. Gast (1968) Lead isotope compositions and uranium decay series disequilibrium in recent volcanic rocks. Earth Planet. Sci. Lett. 5: 199-206.

Oxburgh, E. R. and D. L. Turcotte (1968) Mid-ocean ridges and geotherm distribution during mantle convection. J. Geophys. Res. 73: 2643-2661.

Ozima, M. and S. Zashu (1983) Primitive helium in diamonds. Science 219: $1067-1068$.

Palacz, Z. A. and A. D. Saunders (1986) Coupled trace element and isotope enrichment in the Cook-Austral-Samoa islands, southwest Pacific. Earth Planet. Sci. Lett. 79: 270-280.

Polve, M. and M. D. Kurz $(1987){ }^{3} \mathrm{He} /{ }^{4} \mathrm{He}$ systematics in spinel Therzolite nodules: in prep.

Porcelli, D. R., R. K. O'Nions and S. Y. O'Reilly (1986) Helium and strontium isotopes in ultramafic xenoliths. Chem. Geol. 54: 237-249.

Poreda, R. (1985) Helium-3 and deuterium in back-arc basalts: Lau Basin and Mariana Trough. Earth Planet. Sci. Lett. 73: 244-254.

Poreda, R., J.-G. Schilling and H. Craig (1986) Helium and hydrogen isotopes in ocean-ridge basalts north and south of Iceland. Earth Planet. Sci. Lett. 78: 1-17.

Richardson, S. H., A. J. Erlank, A. R. Duncan and D. L. Reid (1982) Correlated $\mathrm{Nd}, \mathrm{Sr}$ and $\mathrm{Pb}$ isotope variation in Walvis Ridge basalts and implications for evolution of their mantle source. Earth. Planet. Sci. Lett. 59: 327-342.

Richter, F. M. (1986) Simple models for trace element fractionation during melt segregation. Earth Planet. Sci. Lett. 77: 333-344.

Ringwood, A. E. (1982) Phase transformations and differentiation in subducted lithosphere: implications for mantle dynamics, basalt petrogenesis, and crustal evolution. J. Geol. 90: 611-643.

Rison, W. and H. Craig (1982) Helium 3: coming of age in Samoa. EOS 63: 1144.

Rison, W. and H. Craig (1983) Helium isotopes and mantle volatiles in Loihi seamount and Hawailan Island basalts and xenoliths. Earth Planet. Sci. Lett. 66: 407-426.

Schilling, J.-G. (1985) Upper mantle heterogeneities and dynamics. Nature 314: $62-67$.

Schilling, J.-G., G. Thompson, R. Kingsley and S. Humphris (1985) Hotspot-migrating ridge interaction in the South Atlantic. Nature 313: 187-191.

Seitz, M. G. (1973) Uranium and thorium partitioning in diopside-melt and whitlockite-melt systems. Carnegie Inst. Wash. Yrbk. 72: 581-586.

Shaw, H. (1980) The fracture mechanisms of magma transport from the mantle to the surface. In, R. Hargraves (ed) Physics of Magmatic Proceses, Princeton Univ. Press, Princeton, NJ.

Shirey, S. B., J. F. Bender and C. H. Langmuir (1987) Three-component isotopic heterogeneity near the Oceanographer transform, Mid-Atlantic Ridge. Nature 325: 217-223. 
Sleep, N. H. (1984) Tapping of magmas from ubiquitous mantle heterogeneities: an alternative to mantle plumes. J. Geophys. Res. 89: 10,029-10,041.

Smith, T. (1987) M.S. Thesis, Washington University.

Spera, F. (1981) Carbon dioxide in igneous petrogenesis II. Fluid dynamics of mantle metasomatic processes. Contrib. Mineral. Petrol. 77: $56-65$.

Stacey, F. D. (1969) Physics of the Earth. John Wiley and Sons, Inc.. N.Y.

Staudacher, T. and P. Sarda (1987) Comment on "Radiogenic rare gases and the evolutionary history of the depleted mantle" by D. E. Fisher. J. Geophys. Res. 92: 2808-2812.

Staudacher, T., M. D. Kurz and C. J. Allègre (1986) New noble gas data on glassy samples from Loihi seamount and Hualalai and on dunite samples from Loiht and Reunion Island. Chem. Geol. 56: 193-205.

Staudigel, H., A. Zindler, S. R. Hart, T. Leslie, C.-Y. Chen and D. Clague (1984) The isotope systematics of a juvenile intraplate volcano: $\mathrm{Pb}$, Nd and $\mathrm{Sr}$ isotope ratios of basalts from Loihi seamount, Hawail. Earth Planet. Sci. Lett. 69: 13-25.

Steiger, R. H. and E. Jager (1977) Subcommission on geochronology: convention on the use of decay constants in geo- and cosmochronology. Earth Planet. Sci. Lett. 36: 359-362.

Stille, P., D. M. Unruh and M. Tatsumoto (1986) $\mathrm{Pb}, \mathrm{Sr}$, Nd and $\mathrm{Hf}$ isotopic constraints on the origin of Hawailan basalts and evidence for a unique mantle source. Geochim. Cosmochim. Acta 50: 2303-2319.

Subbarao, K. V., G. S. Clark and R. B. Forbes (1973) Strontium isotopes in some seamount basalts from the northeastern Pacific Ocean. Can. $J$. Earth Sci. 10: 1479-1484.

Sun, S.-S. (1980) Lead isotopic study of young volcanic rocks from mid-ocean ridges, ocean islands and island arcs. Phil. Trans. R. Soc. Lond. A 297: 409-445.

Sun, S.-S. and G. N. Hanson (1975) Evolution of the mantle: geochemical evidence from alkali basalt. Geol. 3: 297-302.

Sun, S.-S. and B. Jahn (1975) Lead and strontium isotopes in post-glacial basalts from Iceland. Nature 225: 527-530.

Sun, S.-S., M. Tatsumoto and J.-G. Schilling (1975) Mantle plume mixing along the Reykjanes Ridge axis: lead isotopic evidence. Science 190: 143-147.

Tatsumoto, M. (1966) Genetic relations of oceanic basalts as indicated by lead isotopes. Science 153: 1094-1101.

Tatsumoto, M. (1978) Isotopic composition of lead in oceanic basalts and its implication for mantle evolution. Earth Planet. Sci. Lett. 38: 63-87.

Tatsumoto, M., R. Knight and C. J. Allègre (1973) Time differences in the formation of meteorites as determined from the ratio of lead-207 to lead-206. Science 180: 1279-1283.

Tilton, G. R. (1960) volume diffusion as a mechanism for discordant lead ages. J. Geophys. Res. 65: 2933-2945.

Tru11, T. W., M. R. Perfit and M. D. Kurz (1987) Helium and strontium isotopic constraints on the origin of island arc magmas in the Woodlark Basin: in preparation. 
Vidal, P. and L. Dosso (1978) Core formation: catastrophic or continuous? $\mathrm{Sr}$ and $\mathrm{Pb}$ isotope geochemistry constraints. Geophys. Res. Lett. $\underline{5}$ : $169-171$.

Vidal, P., C. Chauvel and R. Brousse (1984) Large mantle heterogeneity beneath French Polynesia. Nature 307: 536-538.

Vollmer, R. (1977) Terrestrial lead isotopic evolution and formation time of the Earth's core. Nature 270: 144-147.

Wasserburg, G. J., G. J. F. MacDonald, F. Hoyle and W. A. Fowler (1964) Relative contributions of uranium, thorium and potassium to heat production in the Earth. Science 143: 465-467.

Watson, B. (1982) Melt infiltration and magma evolution. Geol. 10: $236-240$.

Watson, E. B., D. Ben Othman, J.-M. Luck and A. W. Hofmann (1987) Partitoning of $\mathrm{U}, \mathrm{Pb}, \mathrm{Cs}, \mathrm{Yb}$, Re and $\mathrm{Os}$ between chromian diopsidic pyroxene and haplobasaltic liquid. Chem. Geol. 62: 191-208.

White, W. M. (1985) Sources of oceanic basalts: radiogenic isotopic evidence. Geol. 13: 115-118.

White, W. M. and B. Dupré (1986) Sediment subduction and magma genesis in the Lesser Antilles: isotopic and trace element constraints. J. Geophys. Res. 91: 5927-5941.

White, W. M. and A. W. Hofmann (1982) Sr and Nd isotope geochemistry of oceanic basalts and mantle evolution. Nature 296: 82 1-825.

White, W. M., A. W. Hofmann and H. Puchelt (1987) Isotope geochemistry of Pacific mid-ocean ridge basalt. J. Geophys. Res. 92: 4881-4893.

Williams, D. L. and R. P. Von Herzen (1974) Heat loss from the earth: new estimate. Geol. 2: 327-328.

Wright, E. and W. M. White (1987) The origin of Samoa: new evidence from $\mathrm{Sr}, \mathrm{Nd}$ and $\mathrm{Pb}$ isotopes. Earth Planet. Sci. Lett. 81: 151-162.

Zindler, A. and S. R. Hart (1986a) Chemical geodynamics. Ann. Rev. Earth Planet. Sci. 14: 493-571.

Zindler, A. and S. R. Hart (1986b) Helium: problematic primordial signals. Earth Planet. Sci. Lett. 79: 1-8.

Zindler, A., S. R. Hart, F. Frey and S. P. Jakobsson (1979) $\mathrm{Nd}$ and $\mathrm{Sr}$ isotope ratios and rare earth element abundances in Reykjanes Peninsula basalts: evidence for mantle heterogeneity beneath Iceland. Earth. Planet. Sci. Lett. 45: 249-262.

Zindler, A., E. Jagoutz and S. Goldstein (1982) $\mathrm{Nd}, \mathrm{Sr}$ and $\mathrm{Pb}$ isotopic systematics in a three-component mantle: a new perspective. Nature 298: 519-523.

Zindier, A., H. Staudigel and R. Batiza (1984) Isotope and trace element geochemistry of young Pacific seamounts: implications for the scale of upper mantle heterogeneity. Earth Planet. Sci. Lett. 70: $175-195$. 
Appendix 1

St. Helena

Sample and Mineral Separate Descriptions

CE IA Porphyritic picritic basalt from river cut near Sandy Bay. $\sim 15 \%$ by volume pyroxene + ollivine phenocrysts, up to $\sim 0.8 \mathrm{~cm}$ in largest dimension, are set in a dark aphyric groundmass.

Subhedral-anhedral olivine phenocrysts are very fresh, showing minor alteration only along cracks. Olivine phenocrysts have spinel inclusions and dark blebs (possibly of sulfide (?), as previously described by Baker, 1969). Subhedral-anhedral pyroxene phenocrysts are non-pleochroic and are intergrown with the groundmass at the margins giving the appearance of corrosion. Olivine and pyroxene are also present as microphenocrysts (in approximately equal proportions). The groundmass shows mild fluidal texture with laths of plagioclase $(25 \%)$ and euhedral oxides $(25 \%)$ in an intergranular matrix of olivine+pyroxene. $M g \#=66$, $\mathrm{SiO}_{2}=45.3 \mathrm{wt}$. $\%$

mineral separates

olivines

$\sim 95 \%$ pure oljvines have $\sim 70 \%$ surfaces with low

reflectivity, but no adhering matrix, and $\sim 0.5 \%$ melt and minor oxide inclusions.

brown pyroxenes

$>80 \%$ pure have $\sim 10 \%$ surfaces with intergrown plagioclase, $\sim 30 \%$ of surfaces with low reflectivity. $>50 \%$ pure have $\sim 30 \%$ of surfaces intergrown with plagioclase and matrix containing opaque oxides.

CE 6 Porphyritic phonolite from near Lot's wife. $25 \%$ phenocrysts of tabular and lath-shaped anorthoclase or sanidine, (up to $0.2 \mathrm{~cm}$ in length) with undulose extinction and fluidal texture, are set in a grayish groundmass with a minor amount of small disseminated mafic crystals. The groundmass shows a weathered, trachytic texture and minor oxides and anhedral nepheline $(\sim 5-10 \%)$ are present as microphenocryst phases. $\mathrm{Mg \#}=7, \mathrm{SiO}_{2}=62.2 \mathrm{wt} . \%$.

CE 13 Porphyritic alkali basalt from near High Hill. $\sim 25 \%$ pyroxene phenocrysts, up to $0.6 \mathrm{~cm}$, set in a dark gray aphyric groundmass. Several vugs $(\sim 0.5 \mathrm{~cm})$ comprise $\sim 5 \%$ by volume of the sample. Phenocrysts of pyroxene are sometimes complexly zoned and are intergrown with the groundmass at their margins. Plagioclase occurs in varieties of multiply twinned, oscillatory and concentrically zoned phenocrysts and sometimes as glomerocrysts with pyroxene. Inclusions of oxides are present in plagioclase and pyroxene, and plagioclase is 
sometimes included in pyroxene. Altered hopper olivine is also present as a minor phenocryst phase. The groundmass shows mild fluidal texture, and is comprised of $\sim 75 \%$ plagioclase, accompanied by intergranular proxene and oxides in approximately equal proportions, with sparse olivine. $\mathrm{Mg \#}=48, \mathrm{SiO}_{2}=45.8 \mathrm{wt} . \%$.

mineral separates

brown pyroxenes

$\sim 80 \%$ pure have $\sim 10 \%$ of surfaces with low reflectivity and $\sim 10 \%$ intergrown with small amounts of plagioclase. Grains are very dark making estimates of. inclusion abundances and types difficult.

CE 14 Trachybasalt from near High Hill. $\sim 10 \%$ plagioclase, less than $0.5 \mathrm{~cm}$, and showing slight fluidal structure, and $<5 \%$ olivine (up to $\sim 0.2 \mathrm{~cm}$ ) are set in an aphyric, dark gray groundmass. Small vesicles $(<0.1-0.3 \mathrm{~cm})$ comprise $\sim 1 \%$ of the volume. The phenocrysts of olivine are altered to iddingsite at their margins, and some glomerocrysts of olivine and plagioclase are present. Oxides are sometimes included in the olivines, and as minor microphenocrysts they sometimes exhibit chain-like structures. The subophitic groundmass shows distinct trachytic texture. $M g \#=41$, $\mathrm{SiO}_{2}=49.7$.

CE 18 Porphyritic ankaramite from northeast of the island near Saddle Point. $\sim 20 \%$ fresh pyroxene phenocrysts, up to $1.5 \mathrm{~cm}$ in size, $\sim 10 \%$ highly weathered olivine and $\sim 10 \%$ vesicles $(\sim 0.1-0.2 \mathrm{~cm})$ are set in a dark gray groundmass. Subhedral pyroxene phenocrysts with mildiy corroded margins are non-pleochroic and sometimes zoned; subhedral-anhedral olivine phenocrysts are nearly completely altered. Glomerocrysts of plagioclase $\simeq 01$ ivine $\ldots$ pyroxene occur, and plagioclase occurs as concentrically zoned and multiply twinned crystals. Oxides are included in plagioclase, olivine and pyroxene. Plagioclase also occurs as a sparse microphenocryst phase. The groundmass is comprised $\sim 75 \%$ plagioclase set in an intergranular matrix of approximately equal proportions of pyroxene, olivine and Fe-Ti oxides. Mg\# =51, $\mathrm{SiO}_{2}=$ 46.9 wt. $\%$.

mineral separates

olive green pyroxene

pristine type is more than $99 \%$ pure, with no adhering matrix and no detectable melt or oxide inclusions; some small fluid inclusions may be present. All surfaces have high reflectivity. $\sim 80 \%$ pure has no adhering matrix, $\sim 20 \%$ of the surfaces with lower

reflectivity, and $\sim 1 \%$ melt inclusions.

brown pyroxene

$\sim 90 \%$ pure has $\sim 10 \%$ surfaces of low reflectivity, very minor amounts of intergrown plagioclase, and $\sim 2 \%$ melt inclusions. 